\title{
HEALTH PROGRESS \\ AND ADMINISTRATION \\ IN THE WEST INDIES
}

\section{SIR RUBERT' BOYCE,FER.S.}



dun

$$
y^{328}
$$





\section{HEALTH PROGRESS AND ADMINISTRATION}

IN THE WEST INDIES 
WORKS BY THE SAME AUTHOR

A TEXT-BOOK OF MORBID HISTOLOGY, 1892. ANTIMALARIA MEASURES AT ISMAILIA, 1904. REPORT ON THE SANITATION AND ANTIMALARIA MEASURES IN BATHURST, CONAKRY, AND FREETOWN, 1905.

YELLOW FEVER PROPHYLAXIS IN NEW ORLEANS, 1905.

REPORT ON YELLOW FEVER OUTBREAE, BRITISII HONDURAS, 1905.

MOSQUITO OR MAN? 1909. 
Digitized by the Internet Archive in 2007 with funding from Microsoft Corporation 


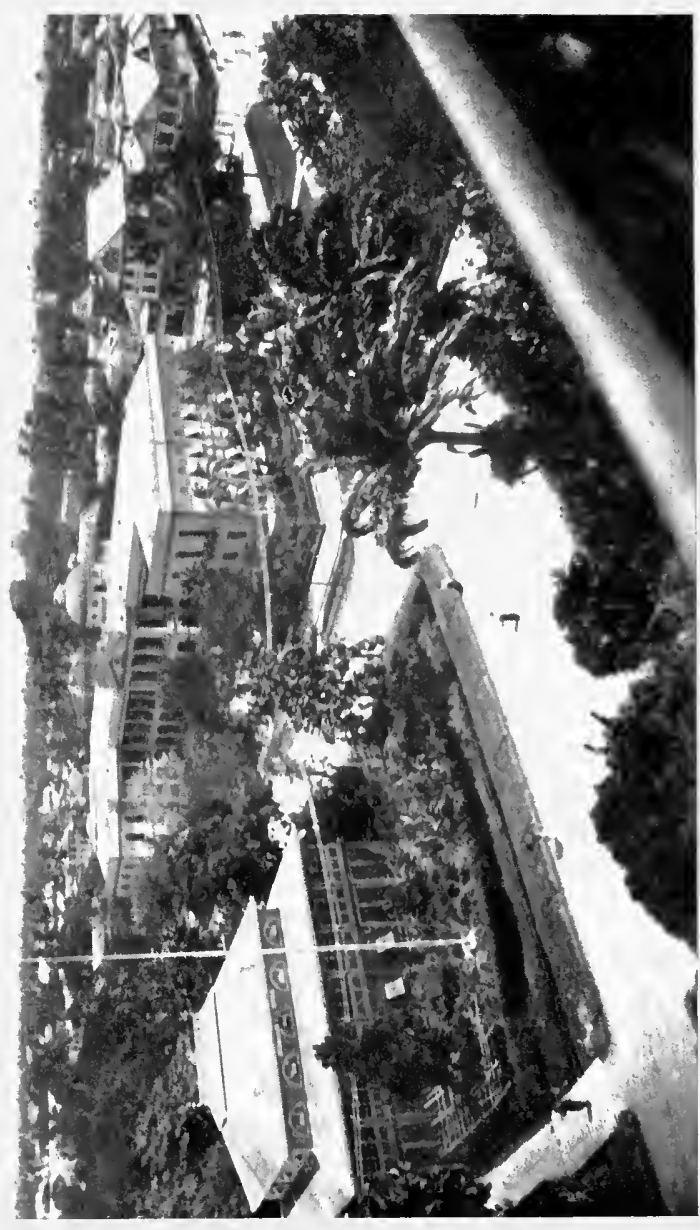

年 


\section{HEALTH PROGRESS AND ADMINISTRATION IN THE WEST INDIES}

\section{BY SIR RUBERT W. BOYCE, M.B., F.R.S.}

PROFESSOR OF PATHOLOOY, UNIVERSITY OF LIVERPOOL; DEAN OF THE LIVERPOOL SCHOOL OF THOPICAL MEDICINE; BACTERTOLOOIST TO THE CITY OF LIVERPOOL; MKMBER OF THE ROYAL COMMISSION ON TUBERCULOSIS; COMMANDER OF THE ORDER OF LEOPOLD II. ; FELLW OF UNIVERSITY COLLECE, LONDON, ETC.

\section{WITH ILLUSTRATIONS}

"Wear a smile on your face, and a flower in your buttonhole." - The Password durine the New Orleans Yellow Fever Epidenic, 1905.

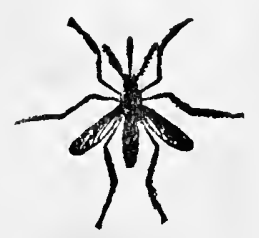

\section{LONDON}

.JOHN MURRAY, ALBEMARIE S'TREEI, W. 



\section{TO \\ THE RIGHT HONOURABLE JOSEPH CHAMBERLAIN, M.P.}

The Statesman who realised the dreams of those who, like Dr. Joln Davey, F.R.S., of 1849, hoped that the day would come " when instruction would be given in the diseases of the army by competent teachers to candidates for commissions in the Medical Department, by which means the attention of young men might be directed to enquiry. Questions, of which there are so many unsolved, might be proposed, and be investigated as opportunities offered in their after career, the solution of which would greatly advance medical science, and would not fail to improve medical practice"

THIS SMALL WORK ON SANITARY PROGRESS AND ADMINISTRATION IN THE

WEST INDIES IS INSCRIBED, BY ONE WHO HAS FOLLOWED THE TROPICAL MOVEMENT SINCE ITS INCEPTION 



\section{PREFACE}

This epitomised record of the Progress of Sanitation and Sanitary Administration in the West Indies is the outcome of a visit which I paid to the West Indies at the request of the Right Hon. The Secretary of State for the Colonies to Barbados in March 1909, in order to investigate an epidemic of Yellow Fever which was present in the colony at the time. Whilst making investigations into the subject of yellow fever in Barbados, I was requested by the Governor of the Windward Islands, and the Governors of Trinidad and British Guiana, to prolong my stay and visit their respective territories, and to report upon the health conditions obtaining in these colonies. I gladly availed myself of the excellent opportunities held out to me, and I trust that the narration of my experiences as described in the present volume will be of use, not only to the medical and business man, but also to the tourist who wishes either to reside in or to visit these beautiful colonies. I hope also that this work will serve as a small introduction to the history of yellow fever in the West Indies, and that it will encourage students to travel in order to investigate diseases on the spot. 
In investigations such as I undertook, everything depended upon the willingness of the local authorities to give assistance and to co-operate with me in my work. In this volume I hope I have given credit for the immense amount of kindness, consideration, and help which I received upon all sides.

To the Governors and Administrators of each colony I respectfully tender my sincere thanks: they invited me to make my headquarter's in Government House in each colony; they brought me in contact with all classes of society, and in every way made my stay of immense interest and profit. To my colleagues of the medical profession I also express my warm thanks for the great kindness and assistance which they extended to me; knowing by experience the difficulties which beset medical administration, I was much gratified to see everywhere striking evidence of sanitary progress and medical organisation.

To the numerous other officials, many of them old friends, and to those citizens who extended to me their hospitality, I tender my thanks.

To the sanitary inspectors, who were my constant companions, and to the ministers of religion, who on numerous occasions expressed their willingness to cooperate and place at the service of hygiene their splendid organisation, I wish to especially record my war'm appreciation.

I also desire to express my sincere thanks to Sir Owen Philipps, K.C.M.G., the Chairman, Directors, and officers of the Royal Mail Steam Packet Company, who not only generously franked my travelling, but in 
every way assisted to make my journey pleasurable whilst on board their splendidly equipped steamers; to Sir Alfred Jones, K.C.M.G., Chairman of the Liverpool School of Tropical Medicine; and, finally, I wish especially to thank my friend, Mr A. E. Aspinall, Secretary of the West India Committee, for much friendly advice and criticism during the preparation of this work.

Rubert Boyce.

'The University of Liverpool,

January 1910. 



\section{CONTENTS}

CRAP.

I. Fragments of the Early History of Yellow Fever in THE West INDIES . . . . . . . 1

II. Then and Now. The Great Mortality from Yellow Fever and Other Diseases in the West Indies in the Eighteenth and Nineteenth Centuries .

III. The Old and the Modern Views of the Nature aNd Mode of Transmission of Yellow Fever .

IV. Sone of the Factors which have made the West Indies Healthier. Pipe-borne Water-supplies versus BARRELS . . 34

V. Education as a Prophylactic Factor in the West INDIES

VI. The War against Insect Pests in the Wes't Indies . 49

VII. The Law agatnst Stagnant Water in some of the West Indian Colonies . . . . . . 54

VIII. 'Trade Routes and the Extension of Disease . . 76

IX. The History of the 1907-1909 Yellow Fever outblieak in Barbados

X. Health Progress and Adninistration in Barbados . 122

XI. Health Progress and Administrition in Grenada • 149

Ait. Health Progress and Administiation in St Vincent . 162

Nili. Healith Progrefse and Admintstration in St Lucla • 174

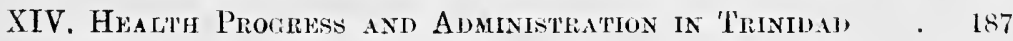

XV. Health Progress and Amministration in Brithe Guiana 228 xi 
Appenuiceis-

A. Circulars and Reports relating to Ankylostomiasis in British Guiana and in the West Indies

B. Reports relating to the Mosquito-carried Diseases in St Lucia . . . . . . .

C. Circulars and Notices relating to Mosquito Destruction and Yellow Fever in Barbados . $\quad . \quad$. $\quad$. $\quad . \quad 268$

D. Correspondence in Connection with the Question of tardy notification of Yellow Fever in Barbados . .

$E$. Circulars and Reports relating to Plague and Rat Destruction in Jamaica, Grenada, Trinidad, and British Guiana .

F'. Eruptive Fevers, Atypical Smallpox, etc.

$G$. Health Progress in the French West Indies, Martinique, and Guadeloupe . . . . . . . . $\quad$. 292

II. Health Progress in the Republic of Cuba and in Porto Rico 299

I. Health Progress in Jamaica . . . . . 302

$J$. Health Progress in the Bahamas and in the Northern Islands 304

K. Health Progress in British Honduras . . . . 305

ConCluston . . . . . . . . . . . . 311

Bibliography . . . . . . . . . . 313

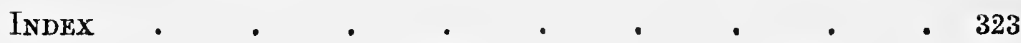




\section{LIST OF ILLUSTRATIONS}

rıo.

1. View of Georgetown, Demerara . . . . Fontispiece

2. Stegomyia calopus . . . . . . . . Facing 26

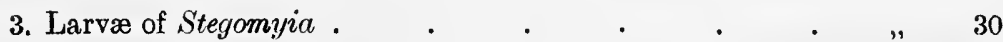

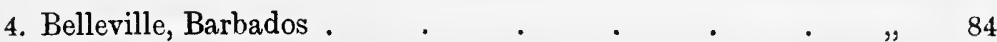

5. Plan of Bridgetown, showing Breeding Places of Stegomyia $\quad$, 86

6. Plan of Bridgetown, showing Distribution of Cases of

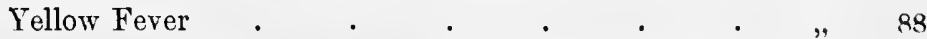

7. Plan of Barbados, showing Distribution of Yellow Fever

Cases . . . . . . . . . .

8. An Emergency Hospital, Barbados . • . . . " 110

9. A Mosquito-proof Room, Emergency Hospital, Barbados $\quad$ " 112

10. House Inspection, Bridgetown, Barbados . • . " „ 122

11. Filling up Land with Odd Receptacles, Bridgetown " 124

12. Removing Odd Water Receptacles, Bridgetown, Barbados $\quad$ " 126

13. Plan of Bridgetown, showing Position of Water-tap . " , 130

14. Coast Scenery in Barbados . . . . . . " 142

15. Coast Scenery in Barbados . . . . . . . " , 144

16. View of Harbour of St George, Grenada . . . . , 148

17. View of Town of St George, Grenada" . • • • " $\quad$ • 150 
F1G.

18. Plan of Town of St George .

19. Kingstown, St Vincent, looking West

20. Kingstown, St Vincent, looking East

21. Plan of Kingstown, St Vincent

22. Town of Castries, St Lucia .

23. Plan of Port of Castries, St Lucia .

24. Road in Port of Spain

25. Plan of Port of Spain and Suburbs.

26. Map showing Trinidad and Venezuela

27. A Large Concrete Drain, Port of Spain

202

28. Large Concrete Drains, Port of Spain

29. Concrete Roadside Drain, Port of Spain .

30. Small Roadside Concrete Drain, Port of Spain

31. Large Concrete Drain passing under Roadway, Port of Spain

32. Coolie Panges, Trinidad

33. Coolie Panges, Usine Madelaine, Trinidad

34. Interior of an Estates Hospital, Trinidad .

35. View of Georgetown, Demerara

36. Plan of Georgetown, Demerara

37. A Large Central Ornamental Canal, Gorgetown, Demerara .

38. A Side Trench, Georgetown, Demerara

39. A Grass-grown Side Trench, Georgetown .

40. Yards in Georgetown, showing Wooden Vats

41. Yards in Georgetown, showing Barrels

42. Coolie Ranges and Latrines, Pln. Diamond, Demerara 


\section{IIST' OF ILLUSTRATIONS}

FIf.

PAGS

43. Estates Hospital, Pln. Diamond, Demerara . Facing 246

44. Small Mlosque for Coolies, on a Plantation, Demerara . „ $\quad 250$

45. Water-holding and Mosquito-breeding Epiphytes upon a

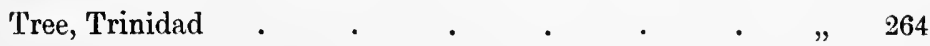

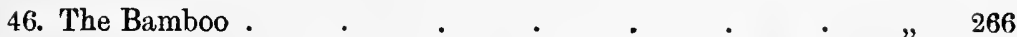

47. A Simple Form of Mosquito Trap made out of Biscuit Tins, the Interior of which has been blackened $\quad$. $\quad, \quad 292$

\section{A P}

West Indies (in Colour) 




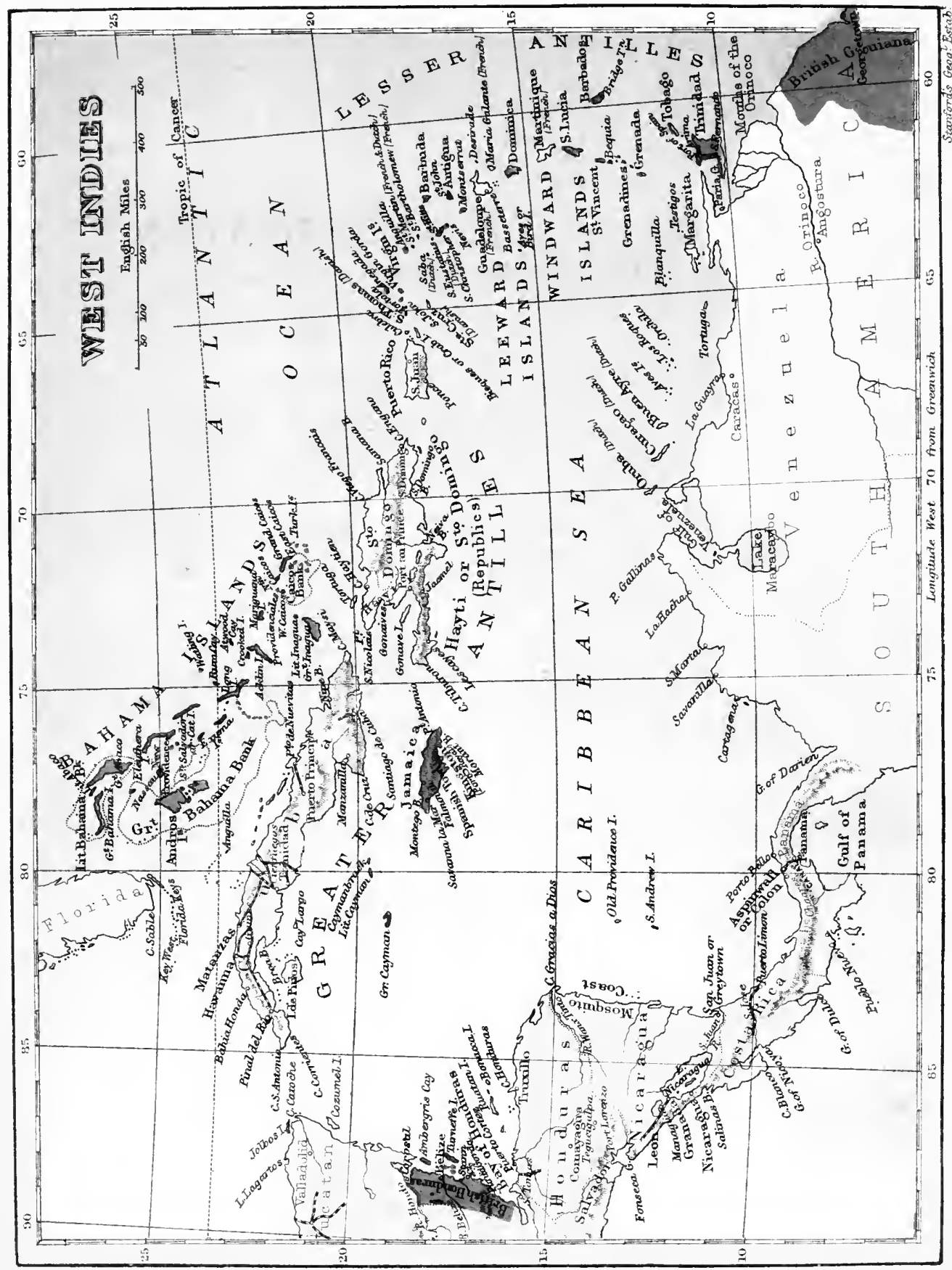




\section{HEALTH PROGRESS AND ADMINISTRATION IN THE WEST INDIES}

\section{CHAPTER I}

FRAGMENTS OF THE EARLY HISTORY OF YELLOW FEVER IN THE WEST INDIES

There is a strong flavour of romance and fascination about the history of Yellow Fever in the West Indies and on the Spanish Main, as about all things attaching to those parts of the world. Yellow fever was the worst enemy which the Conquistadores or the Discoverers of the New World had to encounter. We read how it was known to the ancient Mexicans, and of the bitter complaints of Columbus to his sovereign upon the deadly effect which fever produced amongst his men. Indeed the mortality in the ranks of the early Conquistadores in a very large measure helped to strip the gilt off the gingerbread of the El Dorados, the "cities whose streets were paved with gold."

So bad indeed was it, that Spain could only furnish supplies of men by forcible deportation-a method which was later on practised by Cromwell, when after the Irish Rebellion he "gave Barbados" to many a poor peasant. 
The first recorded outbreak of yellow fever in the West Indies was that which occurred in the city of Isabella, in St Domingo, at about the time of its foundation by Columbus in the year 1493. Another epidemic is recorded at Capara, in Porto Rico, in 1508. Another in St Pierre, in Martinique, in 1735. The foundation of these towns was heralded almost as a matter of course by an outbreak of yellow fever.

Yellow fever is often regarded as a disease peculiar to the Latin races, the explanation, in my opinion, being that the Conquistadores of old, the buccaneers, and the pirates of the Middle Ages were either Spaniards or Portuguese. These nationalities were therefore the first to encounter the deadly yellow fever mosquito; later, when the French followed in their train, they had equally to pay tribute to the Stegomyia; and so with the Dutch, and then with the English, as we shall see in the following chapter.

In recent times the Spanish soldiers in Cuba were much more harassed by yellow fever than by the hostile natives; and in the southern provinces of the United States the same disease almost wiped out the Italian and Sicilian labour population, but only because they happened to form the bulk of the labourers and lived massed together in the poorer quarters, and were surrounded by innumerable water receptacles, which bred Stegomyia in abundance.

We read that in British Guiana the immigration from the Peninsula was discontinued, because yellow fever seemed to single out the Portuguese in preference to the other nationalities. In Chapter XIV., 
devoted to British Guiana, I have attempted to explain this.

The chief chroniclers of the disastrous outbreaks of yellow fever in the Middle Ages in the West Indies were the devoted monks who accompanied the Conquistadores. To this day the names of Père Labat and Père $\mathrm{Du}$ Tertre are well known to many in the West Indies. Père Du Tertre (1635), in his Histoire Générale des Antilles, appears to have been the first to describe the progress of yellow fever in the islands; he tells us how it was known as coup de barre, owing to the intense muscular pains which are characteristic of the disease, and how it attacked those clearing the land and exposed to so-called poisonous vapours and exhalations.

The better-known Père Labat, who landed in Martinique in 1649 , found the disease raging amongst the inhabitants of that island, and decimating the ranks of his own order. The fever was then known, he tells us, as mal de Siam, because it was thought that it was imported from Siam in the ship Oriflamme.

The disease was also known as "Bulam Fever," because it was thought that another ship, the Hankey, brought it from West Africa to Grenada. In Barbados, in the year 1691, yellow fever went by the name of Kendal's Disease.

One of the most striking features in the history of yellow fever has been the marvellous ingenuity displayed by every country to blame some other part of the globe for giving the fever to them.

The West Indians, although themselves severely 
blamed for having introduced the disease into Brazil, the United States of America, Spain and Italy, accused in their turn, as we have just seen, the East (Siam) and Africa (Bulam) for having given it to them.

And even to-day the islands vie with one another in reproaching each other for giving them the disease should an epidemic unfortunately arise. They are exceedingly touchy still upon the subject of these pestilences, and will never admit the parentage of the fever if they can help it.

Writers upon yellow fever of the nineteenth century have commented upon this insular peculiarity. The truth is, that the reluctance to own up means, no doubt, consciousness of guilt; but in the present day it is far better to take the attitude adopted in Psalm xxxviii. and be absolutely frank, for otherwise a reputation for concealment and of not having the courage to face a calamity is the inevitable result. It is a reputation, moreover, which undermines that which all civilised nations are now striving after, namely, health-stability - more precious than financial or commercial stability. Should there be a weak spot in the sanitary organisation of any country, the policy of to-day is to strengthen it, and it is the only policy compatible with commercial progress. Concealment, whether in individuals or communities, leads invariably to the disease smouldering and spreading, and to an ultimate conflagration, when the final results are infinitely worse than the expenditure of the little firmness and moral courage necessary at the outset.

This has been the invariable experience of large communities when face to face with threatened 
epidemics. Boldly notify the first case, and let the sanitary organisation be so armed that implicit reliance can be placed upon it, and in all probability the first case notified will be also the last one.

Yellow fever was not unknown in Europe and in the United States. In the sixteenth and seventeenth centuries appalling epidemics swept through whole provinces in Spain and Italy, and even penetrated to France and England. Time was also when the inhabitants of Boston, Baltimore, and Philadelphia were regularly decimated.

To-day, however, all these places are absolutely secure. In $1905 \mathrm{I}$ took part as a volunteer in the campaign against yellow fever in the city of New Orleans. A few years previously a similar and now historic campaign had been undertaken in the city of Havana, and quite recently Rio de Janeiro and Santos -all of them cities of unenviable yellow fever notoriety -waged war on the mosquito, and to-day they are as secure as are the cities of Boston, Baltimore, and Philadelphia from the ravages of yellow fever. The beneficial change which has taken place in the interval, has made it possible to confine yellow fever to a comparatively small area-to so limit it, in short, that we are really able to state to-day that "yellow fever is a dying disease."

In the following chapter I will review the prevalence and severity of yellow fever in the West Indies in the eighteenth and nineteenth centuries, in order that we may be in a position to measure the progress of sanitation in the West Indies during that period. 


\section{CHAPTER II}

THEN AND NOW. THE GREAT MORTALITY FROM YELLOW FEVER AND OTHER DISEASES IN THE WEST INDIES IN THE EIGHTEENTH AND NINETEENTH CENTURIES

$\mathrm{Br}$ "then" I mean the eighteenth century and the first half of the nineteenth century, at a period in history when the West Indies were described as the "cradle of fever," and had the unenviable notoriety of possessing a deadly fever of their own-a fever bred on the spot, and one which every newcomer, soldier or sailor, merchant, official, or wife, was expected to get before he or she was regarded as "acclimatised" or "seasoned." Fever was the inevitable gauntlet that had to be run by all new arrivals, and very few indeed escaped, as those of us who had parents or relations in the West Indies in those days can testify.

In the engagement before Carthagena in 1741, under Admiral Vernon and General Whitworth, 8431 men lost their lives by fever out of a total of 12,000 . In the siege against Havana, under Count Albemarle, in 1762, a month after landing, 3000 sailors and 5000 soldiers were down with fever. In 1728 it was calculated that the English had lost in their various 
encounters with the Spanish, by fever, 2 admirals, 10 captains, 50 lieutenants, and 4000 soldiers and sailors.

"Then" was the time when "West Indian fever" regularly each year exacted a deadly toll of our garrisons; when yellow fever, better known under one of its many aliases as "ships' fever," swooped down on every ship, war vessel, and merchantman. Those were the days which tried the nerve and endurance of our fathers and grandparents, or at least those of them who survived the deadly disease of not so long ago.

"Then" was also the period when polluted wellwater was the rule, and when in consequence cholera, mal destomac, typhoid, and dysentery occurred in epidemic form. In those days each island port was often an over-crowded, drainless, foul-smelling collection of huts, amongst the inhabitants of which fever was always present. Smallpox, leprosy, tetanus, mal rouge, were common. To give the reader an idea of the prevalence of fevers in the period to which I refer, I insert the following tables and summaries of official reports drawn up in the early part of the nineteenth century.

As the returns were made under the headings of intermittent and remittent fevers, they included the "seasoning" and "acclimatising," the "lowland," "marsh," "jungle," "Jamaica" and other place-named fevers-varieties, no doubt, of malaria and yellow fever, for in those days no sharp dividing line was drawn between these two diseases, malaria and yellow fever. They were both recognised to be essentially local and endemic, and usually present where miasms or emanations from decaying, fermenting, organic matter was 
sure to be found, as, for example, along low-lying coasts, in seaports, in towns and villages near swamps, in valleys, etc. The fevers were not contagious in the ordinary sense : they were not transmitted directly from man to man by contact. Some of them, yellow fever alone excepted, yielded to treatment with quinine.

From the subjoined table it will be seen how soon and how surely the newly arrived seaman was attacked, and with what fatality.

\begin{tabular}{|c|c|c|c|}
\hline Time in Harbour. & Total Cases. & Total Deaths. & $\begin{array}{l}\text { Centesimal } \\
\text { Mortality. }\end{array}$ \\
\hline 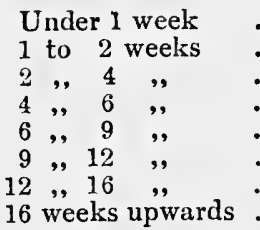 & $\begin{array}{r}19 \\
84 \\
137 \\
98 \\
96 \\
32 \\
17 \\
6\end{array}$ & $\begin{array}{r}1 \\
17 \\
38 \\
31 \\
34 \\
5 \\
1 \\
2\end{array}$ & $\begin{array}{r}5 \cdot 2 \\
20 \cdot 2 \\
27 \cdot 7 \\
31 \cdot 6 \\
35 \cdot 4 \\
15 \cdot 6 \\
5 \cdot 8 \\
23 \cdot 3\end{array}$ \\
\hline
\end{tabular}

The following figures are taken from Dr Browne's analyses of the statistical reports for the army from 1817 to 1836.

In Jamaica, for example, the mortality from fever per thousand was on the average for 20 years in the following stations as follows :--

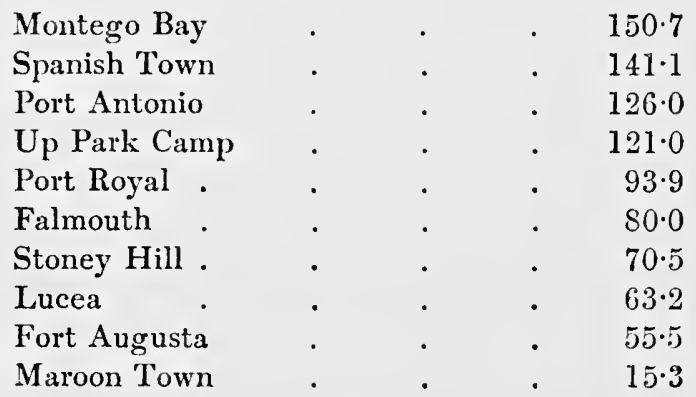


The mortality amongst the black troops was only about 1 per cent.

In another table the following figures are given for Jamaica under the heading fevers :-

Rate per 1000 of mean strength-

Admission into hospital . . 910

Deaths . . . . $101 \cdot 9$

Dr Hunter, in his observations upon the diseases of the army in Jamaica, states :-

Four regiments were sent from England in 1780; they arrived in Jamaica on August 1, and by the end of the following January - that is, after about six months -nearly one-half were dead, and a considerable part of the remainder unfit for service. The average annual death-rate was about 1 in 4 , and in less than 4 years 3500 men had died, and one-half that number had to be discharged, making a total loss to the service of $\mathbf{5 2 5 0}$ men, and that, too, without a single man dying at the hands of the enemy. ${ }^{1}$

In the Windward and Leeward commands, the mortality is given as 1 in 8 from remittent fever. In a period of 18 years the average deaths total up to 5320 .

The following mean mortality rates for 20 years also tell their tale :-

\begin{tabular}{|c|c|c|c|}
\hline Tobago & • & $104 \cdot 1$ & thousand \\
\hline St Vincent & • & $11 \cdot 2$ & " \\
\hline St Lucia & . & $63 \cdot 1$ & , \\
\hline Barbados & . & 11.8 & " \\
\hline Trinidad . & . & $61 \cdot 6$ & , \\
\hline Antigua & • & 41.9 & , \\
\hline
\end{tabular}

1 Dr Maunsell states that from 1817-1836 the annual death-rate amongst the troops was 121.3 per 1000 ; and from $1833-1847$ at the rate of 63.07 per 1000 . A marked decrease then occurred, so 
These figures show the local character of the fevers.

In another part of this report it states that epidemics are rarely, if ever, absent from all the islands in the Windward command, and from the stations in Jamaica. The conclusion arrived at was that the disease which decimated the troops in the West Indies was an endemic disease.

Again, it is stated : "Fever causes five-sixths of the average mortality among the troops in Jamaica." In addition to this mean death-rate, there were from time to time immense increases in the death-rate, caused by recurring epidemics.

In 181830 per cent. of the white troops died in Trinidad from fever.

In Tobago the mortality rate varied from 13 per cent. in 1818 to 80 per cent. in 1820 .

In Dominica the mortality rate from fever in the year 1817 was 29 per cent.

In Antigua and Montserrat, fever prevailed epidemically from 1817 to 1836 . Dr Musgrave has described the epidemic in Antigua in 1816, and notes that it attacked the newly arrived and spared the natives.

In St Kitts, Tortola, and Nevis, fever was often very bad, especially yellow fever.

In the Bahamas the mortality amongst the white troops was thirteen times as great as at home.

Yellow fever is recorded in Martinique from 1791 to 1794, and again in 1802 to 1806 . In 1821 and 1825 epidemics of yellow fever also occurred in that island,

that from $1880-1889$ the rate was 11.36 per 1000 . The chief cause of mortality was fever. 
and 686 cases with 235 deaths are reported from Port Royal Hospital, and 96 cases with 64 deaths in the Basseterre Hospital.

In 1816 and 1821 the epidemic visited Guadeloupe, and 475 cases with 152 deaths are recorded in the Pointe-à-Pitre Hospital.

Yellow fever at this period also raged amongst the ships of the French navy.

In St Domingo yellow fever is described by Gilbert in 1803.

Dutroulau describes the dysentery which was endemic in Martinique in $\mathbf{1 8 5 2}$.

So much for the death-rate from miasmatic fevers in general. Now let us analyse the returns for yellow fever alone, when this disease was differentiated from the others.

Blair, in an account of the yellow fever epidemics of Georgetown, Demerara, 1850, quotes as follows from the report of the Medical Inspector of the West Indian Command for the years 1837 to 1841 :- "About the end of August fever began to appear amongst the noncommissioned officers and privates : out of 32 attacked, 15 died. Intermittent fever was at the same time very prevalent; 1435 cases came under treatment. In Trinidad, in May 1838, fever occurred among the troops at St Joseph's; 15 died out of 109 treated; a draft of young Irishmen, just then arrived, suffered most. In Dominica this year (1837), out of 65 cases of yellow fever admitted into the hospital, 21 died. Nearly all the officers had the disease and died. In this epidemic, hæmorrhage from the gums and throat 
was common; black vomit set in about thirteen hours before death."

In Trinidad (1837), at St Joseph's, 19 men of the detachment there died of fever.

Grenada, about the same time, was severely visited by fever. At Port Frederick, out of 14 men of the Royal Artillery, 11 were attacked, of whom 6 died. At Richmond Hill, out of 207 of the 70th Regiment, 61 were attacked, 14 died. Fever raged amongst the civil population, both white and black; even the acclimatised by no means escaped; the crews of the shipping suffered severely.

In Barbados (1837-8), in November and December, yellow fever prevailed amongst the inhabitants of Bridgetown and proved very fatal. The troops were then healthy. In the beginning of January 1839 the disease appeared in the 52nd Regiment, which, in the November preceding, had arrived from Gibraltar ; of 37 admitted into the hospital 6 died. The officers of the regiment suffered in a greater proportion than the men : of 10 attacked 3 died; 12 were the whole number in barracks.

It is remarkable that every individual who had any duty to perform requiring his presence in the orderly room, which was in the officers' barracks (previously considered healthy), was attacked with fever; and also that few escaped who occupied the adjoining lower rooms. Thus, of 24 persons connected with this part of the building, only 2 females and 4 young children escaped the disease. The building was vacated, the floor taken up but nothing offensive was found underneath.

In the quarter ending 30th June, there was an 
average of 39 deaths out of every 123 cases. The inhabitants at the time were reported healthy, as also the seamen and the troops in Berbice and at the outstations. The weather was described as particularly fine.

In St Vincent, in the same quarter, yellow fever was very destructive amongst the troops: out of 310 (the total strength of the white troops), 241 cases occurred, 54 died; out of 18 officers, the whole in the garrison, 9 were attacked, 4 died.

In St Lucia, from the middle of August to the end of September, the troops at Morne ${ }^{1}$ Fortuné suffered from fever; out of 134 white troops 93 were attacked, 20 died. The inhabitants suffered even more; amongst the latter the disease appeared in the early part of July. The weather was unusually dry and hot. About the same time, the fever was severe and destructive amongst the inhabitants of St John's, Antigua. The troops in the island, however, escaped the disease.

In the quarter ending the 31st December 1839, fever prevailed amongst the troops in Barbados; it was fatal, and chiefly prevailed in the brick barracks. It first appeared amongst the inhabitants in the early part of October, and about the end of the month it became prevalent in the garrison. The hospital sergeant and orderlies of the 52nd Regiment were amongst the first taken ill; then the families of the married men; then the troops in the barracks. The disease broke out amongst the troops on the ships.

In Trinidad, March 1846, fever prevailed; 402 cases occurred, 13 died.

1 "Morne" is a French word equivalent to colline or hill. 
In Tobago, during the same quarter of 1846,62 were attacked with fever out of $71 ; 8$ died.

In St Kitts, out of 8 attacked, 4 died.

In the same year 7 fatal cases of fever occurred amongst the troops in Berbice, 5 in Trinidad, 24 in St Kitts, out of 90 attacked. In the quarter following, of 1840, at St Kitts, there were 10 deaths from fever out of 33 , in the garrison attacked; the civil population suffered as well as the troops. During the twelve months ending 31st March, the deaths from fever at Brimstone Hill, St Kitts, were 49, which was a large proportion of the garrison.

In the garrison of St Ann's, Barbados, an outbreak commenced in December 1847, and resulted in 3 deaths. In the following January 1848, 21 deaths; in February, 2 deaths; in March, 4 ; in April, 4 ; in May, 1 ; in June, 4 ; in July, 5 ; in August, 6 ; in September, 17 ; in October, 13 ; in November, 43 ; in December, 30. In January 1849, there were 5 deaths ; in February, 2 ; all exclusive of officers. A table is also extant, showing the prevalence of yellow fever in Barbados from 1815 to 1846 , and it shows that yellow fever was continually present. In another table the percentage of admissions into the military hospitals of Barbados for yellow fever are given as follows:-

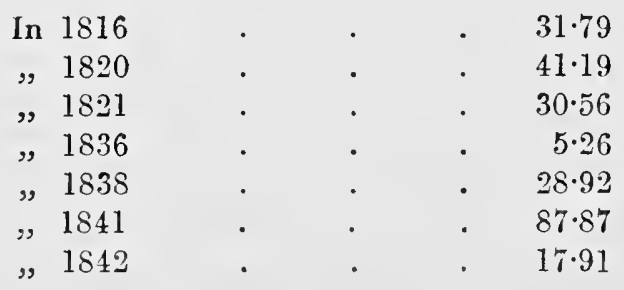


It is worthy of note that there is no record of intermittent fevers in these entries.

Blair drew attention to the fact that the garrison of St Ann's, Barbados, remained free from the intermittent fevers, as also those of Brimstone Hill, St Kitts, and Fort Charlotte in St Vincent, whilst they were attacked by yellow fever.

It is recorded that shortly after the erection of Fort Charlotte near the town of Nassau, in the Bahamas, almost the whole of the 47th Regiment, including men, women, and children, were swept off by yellow fever in a few weeks; this was at the end of the eighteenth century. In 1802 the 7 th Fusiliers buried 220 men out of 300 in an equally short period. In 1803 the fever again broke out and reduced the 300 men to 50 ; these were saved by removal to another spot; they, however, later returned, and the commanding officer and nearly every man died. In the year 1818 the 15th Regiment lost 40 men in six months, and there were many deaths amongst the women and children, and, it is added, not a man of the whole force was fit for duty. No wonder Fort Charlotte was called the "Abode of Death."

Of forty regiments, states the report, in the Windward and Leeward Islands, between the years 1816 and 1848 , only ten regiments were found which had not suffered from black vomit to a greater or less degree. None escaped in Jamaica. In both commands, out of the fifty-three regiments, thirty-three regiments were attacked with black vomit within twelve months after arrival. This, adds the report, shows pretty accurately that the arrival of the stranger at almost any time or 
season in the West Indies was sufficient to develop yellow fever. Sporadic cases were of annual occurrence in the West Indies. In 1805 the 18th Foot, soon after landing in Barbados, in about three weeks lost $\mathbf{1 1 0}$ men and 7 officers.

From 1817 to 1836, in the garrisons in Jamaica, amounting at that time to 2578 men, the deaths from intermittent and remittent fevers rose to 258 men ; they were by far the largest causes of the death-rate amongst the men.

At Mole St Nicholas, St Domingo, yellow fever broke out amongst the newly arrived garrison, and 1500 soldiers, the original complement of the men, perished, whilst the inhabitants lost only 30 , of all ages.

Dr Blair, in his history of the 1847 epidemic of yellow fever in British Guiana, gives a table showing the deaths among the sailors in the Seamen's Hospital, Georgetown :-

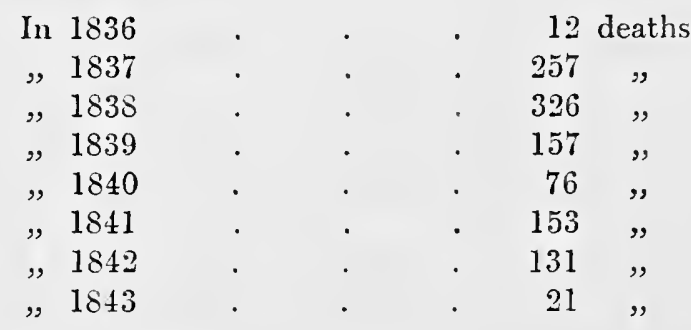

The deaths recorded above were no doubt largely, if not entirely, due to yellow fever. So bad indeed became the reputation of Georgetown, that seamen could scarcely be induced upon any terms to ship for Demerara, and of those who did ship, many stated that they had been grossly deceived, not a few who had 
"shipped for Norway finding themselves ultimately moored in the Demerara River!"

The following is Blair's graphic description of the land close to the military grounds :-

There were many hundred acres of jungle, forming a well-sheltered swamp and a marsh of 250 acres, and during each high spring tide the sea covered the surface of the marsh. The soil was composed of the usual constituents of foreshore; the surface was jagged by a vast number of half-rotten stems and roots. The marsh was tufted with a coarse grass, under whose halfwithered leaves myriads of insects sheltered. Innumerable crabs burrowed throughout. Fragments of driftwood, bones, dead spawn, dried mollusca, and small fish left by the drift of the tide, were scattered profusely over the surface. Near the public roads were small gullies, communicating apparently with the jungle, lined with cryptogamic plants and containing frothy, putridlooking water. Within the trenches aquatic larvæ and exuviæ abounded, and over them clouds of mosquitos and sandflies.

Such was the condition of the neighbourhood of the military grounds during the epidemic. These particulars were noted by Dr Blair more especially in 1840, in consequence of a reference being made to him by His Excellency the Governor, with a view to reply to a dispatch from the Right Hon. the Secretary for War, regarcling the question why in a few months 69 per cent. of all the white troops had perished? "In close proximity and to the leeward of the marsh stood the military hospital. It is said that almost every case admitted to the hospital during the epidemic developed yellow fever, no matter what the ailment on admission; 
and it ultimately became such a terror to the soldiers, that the utmost difficulty was experienced in persuading them to enter it when sick."

In another passage Blair tells us, in his description of Georgetown: "Over some of the Stellings, where the water is quiescent, the most offensive smells arise, and the white paint of the wooden houses is speedily reduced to metallic lead."

No wonder that in those days our soldiers and sailors, brave fellows as they were, shuddered at the thought of entering the hospitals, which were in truth but veritable abodes of death.

I have adduced sufficient evidence to show the frightful mortality which the mosquito wrought in those days, whether it was malaria or yellow fever, and which earned for the West Indies an unenviable reputation-a reputation so bad that the Old and New Worlds regarded the West Indies as the "cradle of fevers," the foci from which yellow fever spread to Europe, the United States, Central and South America.

Since the days of 69 per cent. mortality and the days when, as Blair said, foul smells blackened white paint, immense progress has been made.

Let all credit be given to those pioneers of civilisation who have to-day brought about the conditions which I will shortly describe, and which are surely converting the West Indies into the fascinating health resorts so well described by Charles Kingsley, Sir Frederick Treves, and many others.

Before describing the measures which have produced this sanitary revolution, I will devote the following 
chapter to the review of the old opinions held about the origin of West Indian fevers, and to the modern discoveries of the relationship of mosquitos to disease, the application of the latter of which will steadily bring about the complete extinction of both malaria and yellow fever. 


\section{CHAPTER III}

THE OLD AND THE MODERN VIEWS OF THE NATURE AND MODE OF TRANSMISSION OF YELLOW FEVER

As American writer, describing the various theories which have been held in the past about the origin of plague, has said, "there were notions about original sin, the wrath of God, comets, blazing stars, flaming swords in the sky, juxtaposition of planets, and other mediæval mental garbage."

So with yellow fever in the past, the theories have been as numerous as the medicine men of the period. In the West Indies the theory that the Gulf Stream was the cause of the fever has gained much support from the fact, doubtless, that they have always had both. ${ }^{1}$

Amongst the more serious observers, the emanations, exhalations, or miasms from marshy ground, or from any fermenting vegetable or animal matter, were regarded as the great cause, but they recognised also that something additional was required, as these emanations also occurred in cold climes where there was no yellow fever,

1 Almost all old observers are agreed that the disease was not contagious from person to person, and innumerable experiments were made to show this. See Blair, Dariste, etc., etc. (Bibliography). 
so they argued that a "certain tropical temperature," or "concatenation of circumstances," such as are to be found in the tropics, were necessary. Writers also spoke of the "death shroud of the Savannas," "atmospheric envelopes," "segments of climate," which were carried by ships from one country to another. The atmosphere of the tropics was the dangerous element.

Given the exhalations, the febrilifying atmosphere, and a new arrival, yellow fever must break out. Dr Gilkrest, in describing the great, and at that time exceedingly perplexing, epidemic of yellow fever in Gibraltar, said :- "The mass of those attacked merely marched to their guardhouses, to which certainly the inhabitants were not in the habit of resorting, and where the soldiers as certainly came in contact with no persons suffering from yellow fever. Arrived at his post a soldier was placed at sentry, not in the midst of the dense population; not with people about him from whom disease might be transmitted, nothing of this occurred. The guards in charge of the ruins of Pompeii were not in the midst of a deeper solitude than were often the soldiers of Gibraltar, as they inhaled the 'death blast' in a district abandoned by the inhabitants. The men were far removed from contact with sick people, far out of hearing, far out of sight." But for all that the unobserved mosquito was there.

Time and time again the flooring of barracks and of hospitals has been torn up to try and find out whence came this supposed deadly miasm, this death blast, but as often all was found clean. 
Authorities at one time concentrated suspicion upon that form of miasm which was supposed to arise from the mixture, in a marsh or on a mud flat, of salt with fresh water. This condition of affairs of course happened in nearly all the seaport towns of the West Indies, the fresh water of the estuary met the sea, and as yellow fever was usual in all these seaports here again was cause and effect. Graveyards were a special source of terror; so much so, that bye-laws were enacted, so I am informed, to prevent new arrivals from visiting them. All authorities were clear that yellow fever was not contagious from person to person; they had not hesitated to make direct experiments to test this, and there were the direct observations in the hospitals, that neither the nurses nor the wives of the sick soldier's contracted it. So finally Fergusson concludes in the phraseology of the period: "It is a terrestrial poison which high atmospheric heat generates amongst the newly arrived, and without that heat it cannot exist." "But rubbish!" says the great and thoughtful man, Beauperthuy; "the small amount of sulphuretted hydrogen or marsh gas which might arise from a marsh could not possibly hurt a fly, much less a man. It is not that; it is a mosquito called in Cumana the "Zancudo bobo,' the striped or domestic mosquito." But Beauperthuy was far ahead of his time, and they did not listen to him, and they held hard on to miasm and tradition, as do a few old men still to the present day. Surely, they repeated, it must be a miasm, for yellow fever was once a common disease on ships. In those days it practically broke out on every vessel in 
the yellow fever zone, and what else could have been the cause, but the foul smells or miasms from the bilge? The green logs in the hold, or the mud, or the gravel, or the stone ballast? At that period cargoes were consigned to the deep, ships were scuttled and sunk in disgust, and when economy had overcome the sanitary scruples of the owners, they were raised again-alas! to be followed by recurrent outbreaks. Yes, it is in the shipping trade that the student will find the biggest field for speculation into the origin of yellow fever; the tales about the sea serpent are hardly more wonderful ; indeed, there is a hardy sceptic in Barbados who has written quite recently that scientific men, in order to explain yellow fever outbreaks on shipboard, must prove the existence of a "sea mosquito"!

It appears to me, however, that it would be a pity to invoke another sea monster, when we have already the well-known sea serpent; and besides, we know very well that the wooden ship of old was even more prone to harbour and breed mosquitos than the house on shore ; and to-day this fact may be verified in the case of the smaller wooden craft which ply in the estuaries of rivers in yellow fever countries.

It will not be necessary for learned entomologists or doctors to discover the sea Stegomyia; we are content to leave it to the imagination of the amiable but heretical doctor who invented the idea, just as we do in the case of the Ancient Mariner and his sea serpent.

For innumerable ages the miasmatic or telluric theory of the miasmatic fevers-yellow fever and malaria-has held sway, and therefore it is not to be 
wondered that the old doctrines die hard. But it is disastrous if those who ought to know better, and who are in touch with books and newspapers and with younger men, obstinately blind their eyes to the development which has taken place since they themselves were young. In other words, it is indeed disastrous both to individuals and to a courtry, when the mind becomes fixed and inflexible; it is the sign of stagnation, and that the elasticity of youth has departed. Of course there is another class, which includes the ignorant, superstitious, and prejudiced, who actively campaign against any reform, and who are the means of doing incalculable harm in young communities.

I was informed of many instances of this type in the West Indies-of how a newspaper in one well-known and naturally beautiful and healthy island, solemnly proclaimed during a smallpox epidemic that the people ran the danger of their arms dropping off if they were vaccinated. And in another case how during this same smallpox epidemic, a native parson warned his congregation that if they were vaccinated they would pollute the house of the Lord, and therefore, that they should abstain; fortunately that same parson very shortly afterwards contracted smallpox-a circumstance which no doubt changed his tune. I remember, in one island, being in a most friendly and courteous manner interrogated by a member of the local town council, and asked my opinion upon the merits of vaccination. I stated my reasons for believing in the absolute efficacy of preventive inoculation; but my interrogator asked me whether I was aware of the contrary opinions 
uttered by Herbert Spencer, Darwin, W. G. Grace, Marie Corelli, and some others. I pleaded that I was not aware of their views upon the subject, and that whatever opinions these learned people might hold, it would not alter my belief of what I knew to be the unanimous opinion of the medical faculty; and I put it to my questioner, whether, for instance, he thought that a large shipowner of Liverpool would be guided by the above authorities on the best form of construction for a cargo or passenger boat destined for the North Atlantic or Eastern traffic.

These and like views are, however, only manifestations of insularity and ignorance, and will steadily disappear as education spreads, but nevertheless they are irritating and thwarting in times of emergency.

Of course, when the press of a colony takes this attitude, the situation indeed becomes almost hopeless. I am sorry to say that this attitude has not altogether died out, and that the "juju" of Africa is still reflected to a small degree in the West Indies. But it will go as surely as all those other heathen abominations have gone. A much more deadly block to progress is encountered when the profession itself defends its prejudices belind the ramparts of tradition. In a very striking passage in his writings, the great Beauperthuy of Guiana said: "How many centuries did it take the medical profession to break with tradition and preconceived classifications and causes of disease, and to acknowledge that the common skin disease, the itch, was communicated by a parasite?" "It took them 
three centuries," he adds, and "that, too, in spite of the fact that the poor negro was well aware of its parasitic nature!" With the exception of Beauperthuy, Finlay, Harrison, Sutton Moxly, Nott, Carter, and a few others, doctors gave up speculating upon the origin of yellow fever, and resigned themselves to the inevitable, and spoke of "death blasts," "abodes of death," "yellow fever houses," "yellow fever envelopes," "sections of yellow fever climate," and "the something" which the new arrival in a tropical country carried with him, which, when it came in contact with the new conditions of tropical life, caused a veritable yellow fever explosion. The day of deliverance was near at hand, however, and it came when Manson, Ross, Reed, Carroll, Agramonte and Lazear and their numerous co-workers and followers proved that mosquitos conveyed the marsh or miasmatic and other fevers-malaria, yellow fever, filaria, etc. Then, as if by magic, that which before was mysterious and inexplicable became as daylight. The ubiquitous, water-loving, man-following mosquitos were, of course, the obvious agents which transmitted the disease. This fact was not proved by one or two individuals; now every student of tropical medicine verifies it for himself in the schools. The mosquito transmission of disease is an absolute doctrine. But were further proof necessary, it has been furnished in overwhelming mass, by the magnificent results which have been obtained all over the world in preventing these diseases by relying solely on antimosquito measures. I have already, in my work on Mosquito or Man? fully recorded these campaigns against insect life, 


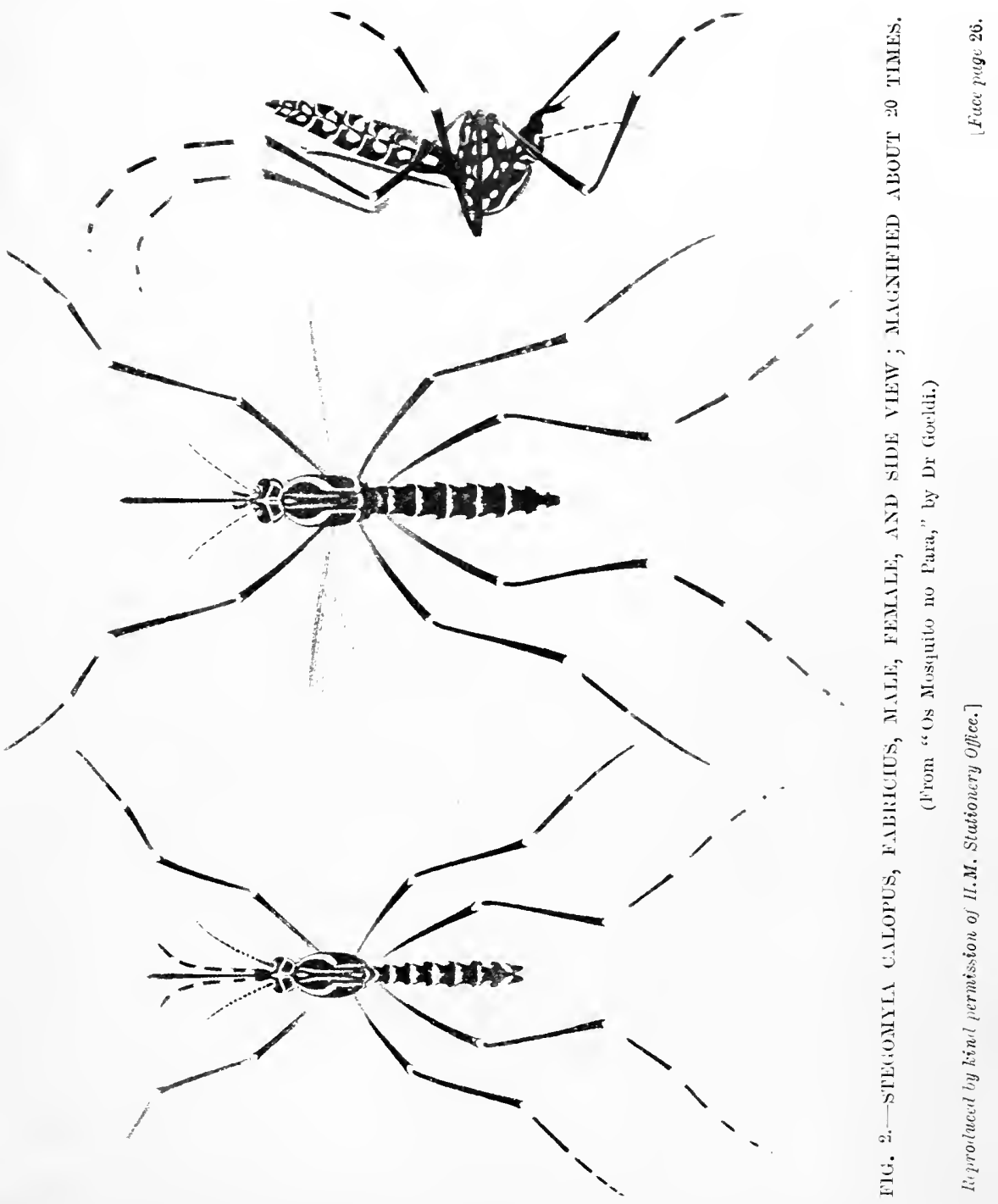



and for further information upon the subject I would refer the reader to it.

The Scientific Data about Yellow Fever, upon which Modern Prophylaxis is based.-Yellow fever is caused by a specific virus, the nature of which is still undiscovered. In the last few years much attention has been directed to find out if possible the nature of the virus, and various protozoa-like bodies have been from time to time described. Recently a spirochæte has been identified in the tissues in cases of yellow fever.

During the first three days of the attack, during which time the patient is capable of transmitting the infection to the Stegomyia, the serum is also infective; before or after these first three days of illness, the serum is said not to be infective. It is stated that serum taken from a patient during the infective period will produce infection in a healthy subject.

On the other hand, evidence points to the conclusion that neither the cadaver, the secretions, nor the black vomit are infective. These are all points, however, the final solution of which awaits the definite discovery of the real nature of the parasite of the disease.

For prophylaxis, however, the data are sufficient and very precise, and, acted upon, yield unerring results. They are as follows:-Whatever the nature of the virus, it is transmitted only by the Stegomyia calopus.

Incubation Period in Man.-The period of incubation in man-that is, the time elapsing after a person has been bitten by an infected mosquito, until the onset of symptoms-is, approximately, five days. 
After the incubation period, and during the first three days of the attack, the patient is capable of transmitting infection to the Stegomyia, but not at other times during the illness.

The Extrinsic Incubation Period.-When the Stegomyia has taken a meal of blood from a yellow fever patient during the three days the patient is infective, it is not capable of immediately transmitting the infectionthat is to say, it does not itself become infective until after the lapse of some $\mathbf{1 2}$ days, and this is known as the extrinsic incubation period. After this incubation period it is capable of transmitting the disease if it bites a healthy person.

This power of transmitting infection persists in the mosquito for many weeks.

The bite of a single infected mosquito suffices to give an attack of yellow fever.

During the cold season, although the mosquitos may not be active and bite, they may remain quiescent in some parts of the house, and upon the advent of war'm weather, become active, and, if infected in the previous year, be capable of transmitting infection and starting a fresh epidemic. These facts explain the persistence of yellow fever in the so-called yellow fever houses, and also the imperative necessity for thorough fumigation in orcler to destroy all infected mosquitos. Neglect of this precaution invariably leads to recrudescence of the fever after the outbreak appears to have ceased.

Our knowledge as to how far the egrgs and larve of infected mosquitos are themselves infected or not and 
are capable of transmitting infection to the imago, is not by any means complete or precise. There is, however, the possibility of transmission of the infection to the brood, and this constitutes a further argument for making every endeavour to destroy the infected mosquito and to get rid of all breeding places.

Our knowledge of the carrier of yellow fever, the Stegomyia calopus, is now very complete.

In the first place, this mosquito has been proved to be the sole carrier of the disease. No infection is carried by the clothes or the bedding of the patient.

The Stegomyia calopus is common in seaports, but extends into inland towns following the trade routes.

It is essentially a town dweller, and is the common "domestic" or "house mosquito." It is not known to be a marsh or swamp dweller.

It is also known as the "tiger" or "Scots Grey" mosquito.

It breeds in the clean water receptacles in the yards of houses, and it is, in consequence, often known as the "cistern mosquito." The actively moving "wrigglers" or "wiggle-waggles" which are found in great abundance in cisterns, barrels, and kerosene tins used for the storage of water, constitute the larval stage of the mosquito.

There is an erroneous opinion that mosquito larvæ purify water by feeding upon pathogenic bacteria; there is no evidence to support this contention. ${ }^{1}$

1 To test the point $I$ have made a series of counting experiments by plate culture, and I find that larvæ largely increase the number of bacteria in water, as indeed one would expect. 
It also breeds in old bottles, meat and condensedmilk tins, flower pots, conch shells, and discarded receptacles of all kinds capable of holding water for a few days, which are commonly found in all badly kept yards and rubbish heaps. It also breeds in rainwater which may collect in canoes, in the lily tubs, and the larvæ may even make their appearance in the watervessels and flower vases in the rooms if the water is allowed to remain undisturbed in them for a few days.

Larvæ are not usually found in gutters, pools, or wells, but, if debarred access to the common water receptacles, the mosquito may be driven to seek unusual breeding places.

It must be remembered that if this mosquito is found in a house, its breeding place is usually close at hand.

Because of the fact that the Stegomyia is a cistern breeder, yellow fever may occur in the wealthier and more sanitary parts of the town as well as in the poorer insanitary districts.

It is readily distinguished from other mosquitos by its very characteristic appearance. It is a "black and white mosquito." There is a lyre-shaped pattern in white on the back of the thorax, transverse white bands on the abdomen, and white spots on the sides of the thorax; while the legs have white bands with the last hind tarsal joint also white.

The mosquito deposits its eggs on the water in the cistern. The eggs develop in from ten to twenty hours into the active wriggling larvæ. The larval or wiggle stage lasts one-half to eight days, and is then followed 


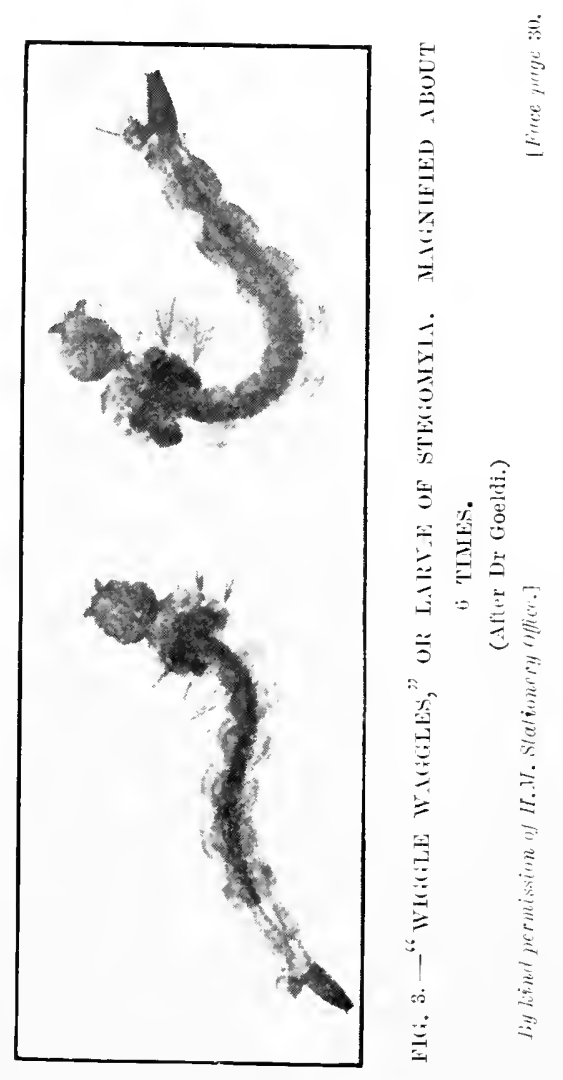



by the pupa stage ; from the pupa, in two days' time or even less, a complete mosquito emerges and flies into the nearest house.

The eggs are resistant and capable of preserving their vitality although removed from water for some ten to ninety days. They may therefore persist for a long period in an empty damp barrel, and develop into wrigglers when the barrel is filled.

The larvæ die in a short time if removed from water; merely emptying water out of a barrel or other receptacle which contains wrigglers will not necessarily get rid of them, as they cling to the crevices, and reappear when fresh water is poured in. In the same way, heavy rains do not wash them out, as erroneously supposed. Careful screening is the only effective remedy to keep out the mosquito, or, still better of course, the abolition of the water barrels and odd receptacles.

As the Stegomyia may seek refuge for breeding purposes in the shallow street drains and wells in the town, these must on no account be overlooked. The shallow street drains and pools should either be filled in or kept well treated with crude petroleum oils.

Wells can with difficulty be properly protected, and should be filled in or constantly oiled. Lily tubs and ornamental ponds should be stocked with fish.

The Stegomyia mosquito attacks its victim noiselessly and persistently, both during the daytime and at night. Therefore it is necessary :-

1. To sleep always under a properly made and securely tucked-in mosquito net, of a gauge of 
18 meshes to the inch. The net should always be tucked-in under the mattress and not hang on the floor. There should be no slit in the sides and no holes. Care should be taken that the arms and legs are not bitten during sleep, through coming in contact with the net.

2. To screen where possible in mosquito-infected districts one living room, a portion or whole of the verandah, or the whole house. (Sleeping in the afternoon without a net is as dangerous as sleeping at night without one.)

3. To remember, as the mosquito avoids currents of air, the freer the through-draft of air the better.

The essential Guiding Principle in Proplyylactic Measures against all Mosquito and Insect-borne Diseases. -The more practical experience one gains of all insect-borne diseases-that is, of diseases which require two hosts : man and an insect-the more one comes to the absolute conclusion that the bed-rock principle of efficient prevention is the extermination of the insect; this is a final and an irresistible plan of attack; other methods, such as isolation, screening, and medication are only palliative. It is with the greatest satisfaction that I notice that H. R. Carter, the well-known yellow fever authority and director of the hospitals on the Isthmian Canal zone, has come to the same conclusion. It was with the object of the total extermination of the Stegomyia, that I worked whilst in British Honduras in 1905, and recently (1909) in the West Indies. Moreover, I find that medical and public opinion, 
wherever I have been, is on the whole in favour of the radical measure rather than, say, the administration of drugs like quinine. For it is rightly agreed that the getting rid of stagnant water is beneficial from every point of view, and that the destruction of mosquitos will probably free the world of other diseases besides malaria, yellow fever, and filaria. In addition, animals are also protected as well as man.

Lastly, this radical measure-i.e., drainage-has had the benefit of many centuries of trial, and we all know what it has accomplished and how malaria and yellow fever have been driven out of countries where once they were prevalent, without the aid of a bottle of medicine. Therefore I say again, stagnation is the great enemy of life, and all our energies must be directed to ridding the inhabitable world of it. 


\section{CHAPTER IV}

SOME OF THE FORCES WHICH HAVE MADE THE WEST INDIES HEALTHIER. PIPE - BORNE WATER - SUPPLIES versus BARRELS

WHY have malaria, yellow fever, cholera, and many other pestilences decreased or died out in the West Indies? The answer is: Civilisation, with its attendant reforms, amongst which stand out education and hygiene: these have produced the beneficial change.

The West Indies have not stood still whilst the rest of the civilised world was progressing; they too have undoubtedly advanced. The date when modern systems of sewage disposal and pipe-borne water-supplies were introduced and the wells superseded, marks the dawn of practical hygienic reform in those islands. The introduction of these modern improvements has saved countless lives, and has been largely instrumental in arresting many diseases which formerly ravaged the Antilles. Cholera and dysentery are no longer terrors, and the conditions which obtained when the dead were literally left to bury their dead will probably never again recur. To-day a wholesome non-polluted water-supply is the rule, and moreover, it is brought to 
the houses or laid to standpipes at convenient places along the country roads. This is truly the greatest blessing of modern sanitation, for it has caused the disappearance of cholera.

With equal truth we can say also that the reason why yellow fever is no longer endemic in Barbados, Trinidad, and the other islands, is that the new system of pipe-borne water has done away with the necessity for storing rain-water; in consequence, barrels, cisterns, and odd water receptacles of all descriptions have been largely done away with. The householder can draw water from the tap whenever necessary; there is therefore no longer the need to store a pint of water for domestic use. This reform, of course, struck at the root of yellow fever, for it was in the barrels and in the innumerable other containers that the yellow fever mosquito-the Stegomyia-bred. Hence, in the days before water-supply reform, the Stegomyia swarmed in the houses in the seaports, and there is good reason to believe that the Stegomyia in those days were always in an infected condition, continually taking up the poison from mild, unrecognised cases, much in the same manner as the Anophelines do the parasites of mild cases of malaria or fever amongst the indigenous inhabitants. It was owing to the presence of these infected mosquitos that if the non-immune-that is to say, the new arrival from Europe-went into an inhabited district, he was sure to get yellow fever; it was the rule, as already observed, with the soldiers and sailors of those days.

We have seen that tradition and custom die hard: 
it is difficult entirely to pull up the finer roots of Obeahism, and it is still quite common to encounter barrels around the water tap, in the yard, and all kinds of receptacles in which the inhabitants dearly love to store their water, in spite of the fact that they can get it from the pipe whenever they want. The result is, that the water stagnates and the Stegomyia breeds, and that every now and then we read of a little epidemic of yellow fever. This is, however, the transition period, and, as we shall subsequently see, owing to the enforcement of wise antimosquito measures throughout the West Indies, we have every reason to believe that the last strongholds of the Stegomyia will be destroyed utterly, and that the day is fast approaching when yellow fever will be only remembered in these islands as a nightmare of the past.

By means of better building bye-laws and the increase of wealth, the old-fashioned port towns have extended, and beautiful avenues are now abundant. A large proportion of the old overcrowded rookeries have been done away with. The storm water is collected in well-made stone or concrete drains, and land has here and there been reclaimed. This has brought about with it the drainage of the subsoil water, and the consequent drying of the soil ; there is therefore less tendency for pools to form in wet weather.

In the days of old it was in these rain-water pools that the Anophelines bred; since they have been done away with, there are now fewer breeding grounds, and there is no doubt that the towns in the West Indies are in consequence becoming much freer from indigenous malaria. 
Malaria has been driven out of the towns, and now only lingers in the valleys or villages, out of which it is hoped, before long, it will in turn be chased. The sanitary reform now taking place in the West Indies is precisely what took place in the United States and many parts of Europe a century or two ago, when malaria was common in places where now it has long since been forgotten.

Again, the dust contractor has been busy, the innumerable old tins and broken receptacles of all kinds peculiar to tropical towns are being gathered up from the yards and buried. Clean-up Guilds have even been formed, as, for example, in Antigua in 1904, and in Barbados during my recent visit this year. It was exhilarating to see the children vying with one another in gathering up the rubbish and putting it on the roadside for the carts. As is well known, it is in these discarded milk, sardine, and fruit tins, jars, pots, etc., etc., that rain-water is liable to collect and mosquitos to breed, hence with their removal a vast volume of the mosquito breeding grounds will go also, and the towns will be healthier in proportion.

I was much impressed during my inspection of the islands by the natural cleanliness and decency of the native inhabitants; in my daily wanderings in and out of their houses and yards, whether in the towns or in the scattered villages, I never encountered offensive sights or smells, such as are unfortunately only too frequently met with in many parts of Europe. Indeed, this natural desire on the part of the inhabitants to help 
themselves, gave the relish to doing all in one's power to help still further to clean up.

The factors which have brought about this improvement in public decency has been the appointment of sanitary inspectors and general medical supervision, the civilising influences of the churches, and the schoolmasters. The elements of Hygiene, and especially that form directly applicable to the tropics and tropical diseases, are now more systematically taught in the elementary schools, more public lectures are given, and in many ways the health crusade is preached, and not least by the intelligent sympathy and encouragement given by the two great and honoured Churches in the West Indies.

A feature in the islands which I visited, and I have reason to believe a feature which is universal throughout the West Indies, which struck me with admiration, was the magnificent provision for the sick and infirm and the mentally afflicted. Too much praise cannot be bestowed upon these admirable humane and civilising institutions. My only lament was that our medical students in England do not come over and see these institutions, and spend some months studying the tropical aspect of medicine. I felt that it would be a revelation to them, and would be the first step towards making them what $\mathrm{Mr}$ Chamberlain dreamt of, namely, medical men, not only of Great Britain, but of the vast British Empire, equally equipped to treat the sick in an English country village, or in some far remote, halfcivilised and distant province of the great Empire.

I fervently hope that the time will come when the medical student's training will not be deemed complete 
until he has gained a practical knowledge of the other diseases of our globe, in which the British have such a large holding. In my opinion, the awakening and broadening of mind which such travelled students would obtain, would be of far more practical use to them, and of a more stimulating nature, than a large proportion of the so-called scientific training, or rather smattering, which they receive in the botanic, zoological, and other laboratories in the present-day university. The colonial hospital of to-day in the West Indies is a reflection of all that is best in the best equipped hospitals of Europe. Simpler perhaps, because the inmates are simple folk, but equally efficient. The latest Listerian principles of surgery and midwifery are, of course, adopted, and the nursing is, as a rule, excellent.

If an example is wanted of true devotion to the alleviation of suffering, let the enquirer pay a visit to one of the well-ordered hygienic lazarettos where the leper is cared for. It may be that the lazaretto visited is nursed by some exiled French Roman Catholic Sisterhood : if it is so, the visitor will soon realise that what is France's loss is our gain, and will wonder that a nation could have dreamt that such cultured, intelligent, and devoted women could be supposed to do any country harm. However, the British sense of freedom and liveand-let-live policy will, I hope, for many a year continue to welcome them to these beautiful islands, where they will still find plenty of useful fields to work in.

I have now written enough to show that there has 
been a steady growth in health organisation in the islands which I visited, and for which the authorities are entitled to great praise.

I will therefore proceed to analyse the prospects of the complete conquest of man over the insect pest in the West Indies, a conquest which would render these islands as healthy and disease free as they are already beautiful and naturally favoured. In the next chapter the reader will judge whether West Indian society is ready for the complete conquest. 


\section{CHAPTER V}

EDUCATION AS A PROPHYLACTIC FACTOR IN THE WEST INDIES

As a firm believer in the necessity of education in all matters relating to health, I seized the opportunity, wherever I went, of addressing the following bodies systematically, namely :-

1. The medical profession.

2. Sanitary inspectors.

3. Members of Town Councils or Boards of Health.

4. Schoolmasters and mistresses.

5. Members of the clerical profession, of all denominations.

6. Legislative Councils.

7. Members of the Chambers of Commerce.

8. Representatives of the Press.

9. The public, through the medium of popular lantern lectures.

In this way, I soon get to know how far the principles of the modern doctrines of sanitation and mosquito destruction have taken root amongst the various classes of society. I am sometimes disappointed 
at the kind of questions put to me, but, on the other hand, I am as often agreeably surprised at the advanced knowledge represented by some of the questions asked. There is no doubt that health primers are much more frequently used in the schools. These elementary health books are of a modern type, such, for example, as those of Prout and Dixon, which explain the dangers of mosquitos. Diagrams relating to malaria and yellow fever are also prominently hung up in the schools, police stations, and other public places. In some colonies systematic instruction is given to those training to become sanitary inspectors. A lot more, however, requires to be done. Medical men, schoolmasters, and clergymen are beginning to come out and to help in the instruction of the public in this great organised endeavour against disease. But not half enough of this useful missionary work is done.

Wherever I have gone, I have always appealed to the clergy of all denominations to assist in the crusade. The clergy have the ears and sympathy of the people, and they have the churches and schoolrooms. Moreover, during my visit to New Orleans in the yellow fever epidemic of 1905 , I had personal experience of what can be done by them. In that trying time, pulpits were gladly given up to teaching the doctrine of cleanliness, obedience to the laws of sanitation, and to the teachings of those who were spreading the true knowledge of the danger of mosquitos.

Directions as to what was best to be done were often issued from the pulpit. I can write from personal knowledge, for I gave short addresses myself in a very 
large number of churches belonging to as many sects. In all the colonies which I visited in this recent tour, I found the clergy anxious to assist. In Trinidad especially, both the Roman Catholic and Protestant clergy were exceedingly sympathetic and desirous to help in every way. As showing how important other nations regard the co-operation of the clergy, I reproduce the text of some appeals issued during times of epidemics. The first is one issued to the clergy of New Orleans during the 1905 epidemic. It runs as follows :-

\section{Appeal to the Clergy.}

\section{New OrLeans, La., July 29, 1905.}

To the Reverend Clergy,-The influence of the Reverend Clergy is such, and their loyalty and public spirit have been so often demonstrated, that we venture to ask your co-operation with the Citizens' Volunteer Organisations in the present emergency.

United action produces the surest results.

We beg to ask that you will speak to your congregations on Sunday, July 30, or at the earliest thereafter convenient to yourself, in behalf of the work now being carried on by the health authorities of the city.

We ask that you will urge them, whether they believe in the "mosquito theory" or not, that they will give their hearty assistance to the authorities, who are attempting to stamp out the mosquito, or at least one source of infection. Urge upon them the patriotic duty of allowing cisterns to be oiled and screened, cesspools to be treated with disinfectants, etc.

Many householders (a small minority, but still enough to work mischief) refuse permission to the oilers and screeners to do the work. This refusal nullifies to a great extent the work accomplished on the premises 
of willing householders. In previous visitations of the fever we have been fighting in the dark, striking at an unknown enemy coming from a mysterious source.

The consensus of scientific opinion fixes upon the mosquito as the agent of transmission of the yellow fever.

The enemy therefore is in sight. So far as your power extends, then, we beg of you to use it for the spread of information concerning the mosquito theory, and to use your influence with your congregations to hold up the hands of the constituted health authorities.

This office will gladly receive suggestions, and will give all possible assistance to the ward organisations.

It is proposed to have two cleaning-up days by proclamation of the Mayor, although this has not at this writing been definitely decided. The daily newspapers will announce it when determined.

We will ask you to bring this matter also to the attention of your congregations.

Similarly, during the 1909 epidemic of plague in San Francisco a committee of clergy met in the Chamber of Commerce to take steps to advance a sanitary crusade; representatives of all denominations met, and it was agreed to recommend :-

1. That every minister of a congregation, according to his own judgment, present from his pulpit to his people the necessity of continuing their efforts in promoting the sanitation of San Francisco, by careful examination of their own premises and by recommending the same thing to their neighbours.

2. That a recommendation be made to the superintendents of Sabbath Schools by their pastors, to incorporate a short talk on sanitation in their addresses to the Sunday School assemblies. 
3. That as far as practicable, mass meetings be organised in the various churches, for the purpose of presenting public discussions on the subject of sanitation in general and the issue now before the people in particular.

The churches themselves started by showing an example to the people by proceeding at once to disinfect their cushions, carpets, etc., and to cleanse carefully all floors.

The representative of the Roman Catholic Archbishop stated that a letter had been sent to every Catholic church in the diocese, directing the pastors to discuss the official notices, which were read in all the Catholic churches. There is no doubt that the clergy can do a very great amount to disseminate accurate knowledge upon health matters and how to avoid disease. They have still a great field in the West Indies; they have already begun well, and $I$ do hope they will persevere, and that the various colonial Governments will supply them with the necessary literature for this good work.

Dr John Guiteras of Havana, in writing upon the subject of " Education as a Prophylactic Factor," says :-

The education of the public in the subject of yellow fever will so guide public opinion that it will be possible to practically eliminate the transmitting factor of the disease, the mosquito-the Stegomyia calopus. ... A campaign against this mosquito must be a general one, and also include those responsible for the transmission of malaria, filaria, etc., thus removing from the tropics and sub-tropics some of the most important causes of morbidity and mortality, and which 
therefore have been serious obstacles to their political, commercial, and industrial progress. Education on this subject, therefore, I consider of prime importance in the prophylaxis of yellow fever, and it is surprising how little has been done, or is being done in this line.

The same feeling, I confess, has often struck me also, especially with regard to my own profession. In these matters, I hold that the medical profession ought to lead; in my opinion, they would certainly enhance and consolidate their position in the community if they would step forward and organise lectures and demonstrations. The people are ripe for sanitary reform, and now want leaders. Medical men have a great opportunity, for it is a winning fight.

In his report to the Surgeon-General of the Public Health Service of the United States, a writer, who had been on yellow fever duty, said insistent and continued effort should be made, through the public press and other available means, to educate the people within the sphere of influence of the Stegomyia calopus, so that they will learn to protect themselves against the invasion or spread of yellow fever, by protecting themselves against the mosquito. Above all, to eradicate the existing fear in the medical profession, as well as among the laity, of declaring the presence of yellow fever.

If the first case presenting the slightest suspicion of that disease were promptly made public and the proper modern precautions taken, there would be no danger of the disease spreading. In fact, the public should be taught to acknowledge the existence of yellow fever in 
their midst with the same equanimity as they do in the case of measles or scarlatina.

Guiteras goes on to say: "I believe, and would recommend, that the method of transmission of yellow fever and malaria should be taught in the schools wherever these diseases are liable to occur. The subject should be taught in the primary grades, for what children then learn they will retain. With these ideas disseminated, it would not be long before public opinion would demand with irresistible force the drainage of swamps and lowlands, and the inspection of houses and premises, to see that they were free of breeding places for mosquitos." These are the opinions of practical men, and they are re-echoed by all those who are engaged upon the subject of health reform. In this respect the British nation is singularly backward in some of its dominions: for example, in India, where there still exists an appalling sickness and mortality rate. The West Indies, Cuba, the Philippines, Brazil, Mexico, Africa, have all started forward on a gigantic health crusade. India alone appears paralysed.

In Trinidad I found that great attention had been paid to instruction about mosquitos and their danger; and a pupil in one of the schools at which I was giving an address showed me in her note-book some excellent studies of mosquito larvæ which she had made. Altogether, I formed a most favourable impression of the work of the Education Department in that colony, and it is a good thing, for Trinidad is placed in a very important and exacting position. It is the connectinglink between the Spanish Main and the West Indies, 
and is in consequence singularly exposed to imported infection, either yellow fever or plague, especially the latter disease; and the education of the public and the diffusion of knowledge about the two diseases will be the best safeguard against these diseases.

The colony will save money in the long run by still further perfecting and increasing its educational system. 


\section{CHAPTER VI}

THE WAR AGAINST INSECT PESTS IN THE WEST INDIES

Following upon the magnificent examples of the cleansing of Havana and the regenerating of the Republic of Cuba, and the establishment of absolute health security amongst the vast labour population upon the Isthmian Canal zone, the West Indian authorities woke up also, and from 1904 there has been a steadily progressive policy of extermination waged against the Stegomyia. In most of the islands there exist wise antilarval measures, which make it an offence to keep stagnant water-that is, to keep water breeding or liable to breed mosquito larvæ. Moreover, fines are now regularly enforced for breach of this byelaw. A policy of this kind is bound to bear fruit, as it has already done in New Orleans, Cuba, Panama, Brazil, Mexico, etc., etc., and will, I am convinced, bring about the total eradication of yellow fever. Such a policy will, moreover, have a most desirable educational effect, and will show the people the significance and danger of insect life, and that in practice it is not so difficult as at first sight might be imagined, to exterminate it. For instance, it will encourage the inhabitants to attack 
in earnest the problem of malaria, for this disease still holds on in an undesirable manner, and it will need a concerted and well-organised campaign to get rid of the Anophelines.

As already a beginning has been made, let us hope that the campaign will be now pushed still more vigorously forward. So also with plague, it has been proved beyond suspicion of a doubt that the rat and its flea spread plague, just as the Stegomyia spreads yellow fever and the Anophelines malaria. If anyone doubts the rat and flea theory, let him read the "Eradication of the Plague in San Francisco," published by the Health Committee of that city - a committee, let it be noted, which was not composed of sentimentalists or theorists, but of hard-headed business men, who took action because it yielded profit and made their city new, and brought increased business. I therefore ask the business men throughout the West Indies to follow as closely as they can the practical experience of business men in other parts of the world, and I feel convinced that they will never regret the lead, but that on the contrary they will reap a rich return. Malaria, yellow fever, and plague are not the only wars in which the West Indies will have to engage; there are the diseases like Filariasis, known under the names of "Barbados Leg," "Fever and Ague," "Rose," etc., also Dengue Fever. These require exterminating equally with other diseases. As they are mosquito-borne, the campaign against stagnant water will accomplish it. Then there is a disease belonging to another class of parasitic affections, known as ankylostomiasis, which is receiving consider- 
able attention in very many parts of the tropical world, and especially in the West Indies, where it strikes at the root of the labour question. This parasitic disease is spread, not through the agency of mosquitos or other insects, but by man himself. Man pollutes the soil, or the water, and his own species become infected either through drinking the polluted water or through the bare skin of the feet from the polluted soil; so the disease makes headway until it becomes a matter of serious concern to governments; for not only does the disease produce a considerable amount of suffering in the individual attacked, and therefore lead to a considerable loss of working time and expenditure for treatment, but far more serious even than that-owing to the anæmia which it induces, it lowers the resisting power of the body to other diseases; it makes, in other words, the system more vulnerable to all the other diseases to which man is liable. It thus comes about that ankylostomiasis (tropical anæmia or hook-worm disease) is one of the most potent factors in swelling the mortality and sickness returns in the tropics. Civilised governments have paid very special attention to it, and reports dealing with the subject have been drawn up by the health authorities in the Philippines and in Porto Rico. The plan of attack is simple-namely, the rigorous prevention of the pollution of soil or water, by the use of properly constructed latrines, and the internal administration of an intestinal disinfectant, such as thymol, to kill and drive out the parasites from the intestines. The matter is also receiving the careful attention of the medical authorities in the West Indies, and regulations have 
been drawn up and every care taken to diminish the disease. The disease can be conquered, just as cholera has been: man's carelessness and ignorance are alone to blame for it.

I have brought forward sufficient indications to show that in the war against diseases, the West Indies are accomplishing much; but they must not rest until they have completely chased out of their midst all of them. Having gone so far, with such marked beneficial results, they must proceed to the conclusion, and so make their naturally favoured islands not only above reproach, but an example to the rest of the tropical world, and India in particular, of what can be done by courage and perseverance. And surely islands in which almost every hill, rock, and bay is linked in the mind with the daring deeds of our heroic forefathers, should find no difficulty in conquering disease, and to be in a position to say: "Yes, our streets were once strewn with the dead and dying-men struck down on the threshold of life by the insignificant but intensely poisonous mosquito ; but to-day, thanks to the knowledge we have gained, we have absolutely put an end to this wanton slaughter, and we can now say that our mortality and sickness rates are as low as they are in Europe, nay, even lower, and our islands must now be regarded as the sanatoria of both the Old and New Worlds.

The insect pests, against which war is being waged, may be divided into the following groups :-

I. Mosquitos.-(a) The Stegomyia, the yellow fever transmitting mosquito, which breeds in and immediately around houses, in all artificial 
collections of water, such as barrels, cisterns, tins, pots, vases, calabashes, broken bottles, etc., etc. (b) The Anophelines, the malaria transmitting mosquitos, which breed in earth pools, grass-grown drains, stagnant ponds, marshes, trenches, canals, in receptacles coated with humus, and certain water-holding plants. The Culicidce, which transmit dengue fever, and filariasis. They breed in gutters and wherever water stagnates and becomes foul.

II. Fleas.-Fleas, which convey plague and live on rats and men, and therefore to be found whereever there are foul drains, or rubbish is allowed to accumulate, or where overcrowding occurs and the yards and houses are not kept clean.

III. The House or SePtric Fly, which mechanically carries the bacilli of typhoid fever, tuberculosis, cholera, and many other diseases to man from infected garbage and excreta. It breeds in filth, excreta, and garbage of all kinds.

IV. Intestinal Parasites.-In a separate category stands the war against the intestinal worm known as the Ankylostomum or Hook-worm, which is the cause of tropical anæmia and of much tropical sickness in general. The worms develop in the excreta of persons suffering from the disease, or in contaminated damp earth. The war against them takes the form of preventing the pollution of the ground by the creation of proper latrine accommodation. 


\section{CHAPTER VII}

"STAGNATION, THE GREAT ENEMY OF LIFE." THE LAW AGAINST STAGNANT WATER IN SOME OF THE WEST INDIES

Antilarval bye-laws and regulations have been introduced in-

1. Barbados.

2. Grenada.

3. St Vincent.

4. St Lucia.

5. Trinidad.

6. British Guiana.

7. Nassau.

8. British Honduras.

They all aim at getting rid of stagnant water; the presence of mosquito larvæ, or mosquito eggs is taken as evidence of such condition. Householders are usually first warned by the sanitary inspectors of the nuisance and danger arising from stagnant water, and are admonished to get rid of it, and to remove all useless water receptacles. Then if on a second visit householders have not complied with the request of the sanitary inspector, or have not taken steps effectively 
to screen from mosquitos any large receptacle, such as a tank, which they may possess, they are summoned before a magistrate.

\section{Antilarval Measures in Barbados.}

In the Public Health Act of 1898 there were up-todate regulations for the destruction of larvæ, but they were not enforced until 1909, when they were re-issued in handbill form as follows :-

Extract from the General Board of Health Rules, 22nd February 1909, confirmed by the Governor in Executive Committee on 26th February, and proclaimed in the Official Gazette on 1st March 1909.

2. The occupier or owner of any premises shall keep such premises free of stagnant water liable to breed mosquitos, and the presence of mosquito larvæ in any collection of water, wherever situated, shall be sufficient evidence that such water is stagnant. All tanks, fountains, pools, ponds, or excavations, made for any purpose whatever, in public or private property, which may contain water, shall be kept stocked with mosquitodestroying fish, or shall be kept covered with a film of petroleum oil.

3. The occupier or ownel of any premises shall keep his premises free of articles (bottles, whole or broken, old tins, boxes, conch shells, etc.) which may retain water and so become the breeding place of mosquitos.

4. All cess-pits which retain water shall be disinfected or oiled, except they be efficiently covered and trapped.

5. All gutters and down-pipes shall be maintained in good repair and free of obstruction, so as to prevent the accumulation of water therein, and so as to allow the ready passage of water from the roofs of houses. 
6. All Inspectors of Health shall have authority to enter any premises at any time between the hours of 7 A.M. to 6 P.M. for the purpose of seeing that these regulations are carried out, and may pour oil, or cause oil to be poured, on the surface of water contained in any receptacle in or on such premises.

Penalty for infringement of Bye-laws of the Commissioners of Health, a sum not exceeding $£ 5$.

Penalty for infringement of Rules of the General Board of Health, a sum not exceeding $£ 10$, to be recovered before a police magistrate.

By order.

\author{
S. E. Brewster, \\ Inspector of Health, No. 2 District.
}

During my visit to Barbados, and afterwards, a vigorous system of house-to-house inspection took place; after warning, if no amelioration took place, the offenders were brought before the magistrates.

From the notes furnished me by $\mathrm{Mr}$ Brewster, Chief Inspector of No. 2 District, the number of receptacles of water emptied containing mosquito larvæ were :-

\begin{tabular}{|c|c|c|c|}
\hline Week ending & March & 13,1 & 1909 \\
\hline , & 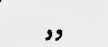 & 20 & $"$ \\
\hline " & & 27, & " \\
\hline , & April & 2 & " \\
\hline ", & ", & 9 & ", \\
\hline , & & 17, & " \\
\hline " & May & 8 & " \\
\hline , & $"$ & 15 & " \\
\hline
\end{tabular}

These figures show that householders were beginning to pay more attention, for there is a decline in the number of receptacles emptied, which contained larvæ. 
Mr Brewster prosecuted in 71 cases, obtaining a conviction in each instance, small fines being imposed. In a few cases the defendants were admonished without a fine.

Chief Inspector Williams, of No. 1 District, in Bridgetown, has also kindly furnished me with the following notes :-

\begin{tabular}{|c|c|c|c|c|c|c|c|}
\hline & Cisterns. & Barrels. & Tubs. & $\begin{array}{c}\text { Saucers } \\
\text { for } \\
\text { Plants. }\end{array}$ & Vases. & Cesspools. & $\begin{array}{c}\text { Total } \\
\text { Receptacles. }\end{array}$ \\
\hline 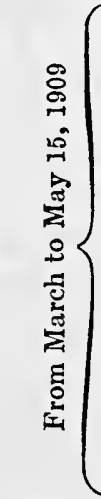 & $\begin{array}{c}1 \\
\ldots \\
\ldots \\
\ldots \\
\ldots \\
\ldots \\
\dddot{1} \\
\ldots \\
\ldots \\
\ldots \\
1 \\
\ldots \\
1 \\
\ldots \\
\ldots \\
\ldots \\
\ldots \\
\ldots\end{array}$ & $\begin{array}{l}14 \\
13 \\
26 \\
43 \\
16 \\
27 \\
36 \\
44 \\
30 \\
28 \\
43 \\
28 \\
55 \\
13 \\
81 \\
87 \\
71 \\
64\end{array}$ & $\begin{array}{r}14 \\
2 \\
4 \\
\ldots \\
3 \\
\ldots \\
4 \\
\ldots \\
\dddot{4} \\
\ldots \\
\ldots \\
19 \\
\ldots \\
\ldots \\
\ldots \\
\ldots \\
\ldots \\
7\end{array}$ & $\begin{array}{l}\ldots \\
\ldots \\
\ldots \\
\ldots \\
\ldots \\
\ldots \\
\ldots \\
\ldots \\
\ldots \\
\ldots \\
\ldots \\
\ldots \\
\ldots \\
\ldots \\
\ldots \\
\ldots \\
\ldots \\
\ldots\end{array}$ & $\begin{array}{c}\ldots \\
\ldots \\
\ldots \\
\ldots \\
\ldots \\
\ldots \\
\ldots \\
3 \\
\ldots \\
\ldots \\
\ldots \\
\ldots \\
\ldots \\
2 \\
\ldots \\
\ldots \\
\ldots \\
\ldots\end{array}$ & $\begin{array}{c}1 \\
\ldots \\
\ldots \\
\ldots \\
\ldots \\
\ldots \\
\cdots \\
\ldots \\
\ldots \\
\ldots \\
\ldots \\
\ldots \\
\ldots \\
\ldots \\
\ldots \\
\ldots \\
\ldots \\
\ldots\end{array}$ & $\begin{array}{l}30 \\
15 \\
30 \\
43 \\
19 \\
27 \\
41 \\
48 \\
30 \\
47 \\
44 \\
29 \\
56 \\
15 \\
81 \\
87 \\
71 \\
71\end{array}$ \\
\hline Totals & 4 & 719 & 54 & $\ldots$ & 5 & 2 & 784 \\
\hline
\end{tabular}

26 persons were convicted for having larvæ in their receptacles. $2 ", \quad, \quad$ larvæ in their gutter.

Fines varied from one to forty shillings.

\section{Antilarval Measures in Grenada.}

In Grenada, under the Public Health Ordinance of 1902 and 1905, regulations were made, April 1907, dealing with larvæ destruction as follows:-

5. Immediately upon any case of yellow fever being reported in any place in a district, the local sanitary 
Authority shall cause regular house-to-house visitations to be made in the vicinity of such place, to ascertain whether any other cases of fever have occurred; and the district Medical Officer shall assist the Local Sanitary Authority and its inspectors in such visitation, and they are hereby empowered to strictly enforce the following measures for the eradication of mosquitos in such place and its neighbourhood:-

(a) No water shall be stored (except in small quantities for drinking purposes), unless efficiently protected against mosquitos by the following method:-

All tanks, barrels, etc., for storing water, shall have all openings except the draw-off opening covered with wire gauze (18 meshes to the inch), or with a piece of cheese cloth, and all fountains, pools, ponds, or excavations, made for any purpose whatever, in public or private property, which may contain water, shall be kept stocked with mosquito-destroying fish, or shall be kept covered with a film of petroleum.

(b) The occupier or owner of any premises shall keep such premises free of stagnant water liable to breed mosquitos, and the presence of mosquito larvæ in any collection of water, wherever situated, shall be sufficient evidence that such water is stagnant.

(c) The occupier or owner of any premises shall keep his premises free of all articles (bottles, whole or broken, old tins, boxes, conch shells, etc.) which may contain water and so become the breeding places of mosquitos, including broken bottles on walls.

(d) All water'y cess-pits shall be disinfected or oiled, and all catch-pits cleaned out at least once a week. 
(e) All eaves-gutters and down-pipes shall be maintained in good repair and free of obstruction, so as to allow the ready passage of water from the roofs of houses.

(f) The District Medical Officer, or any person authorised by him in writing, shall have authority to enter any premises at any time between the hours of 6 A.M. and 8 P.M. for the purpose of seeing that these regulations are carried out.

Since my visit (May 1909), the Board of Health issued the following further regulations :-

\section{Public Health Ordinances, 1902 and 1905.}

Regulations for Declaring the Breeding Places of Mosquitos in and about Human Hatitations to be Statutory Nuisances.

Under and by virtue of sections 11 and 23 of the Public Health Ordinance, 1902, the General Board of Health hereby declares the following matters to be deemed nuisances liable at all times to be dealt with summarily under the provisions of the said Ordinance :-

1. Any accumulation of any stagnant water in any town or in or about any human habitation, which accumulation results from want of proper care or from want of repair to any construction or defective construction.

2. Any articles or receptacles or any construction holding stagnant water, not being a receptacle or construction designed and used for the storage of water.

3. Any receptacle or construction, designed and used for the storage of water, which is not either-

(i) cleared or emptied daily, or 
(ii) effectively screened, from the access thereto by mosquitos with wire-gauze (18 mesh, at least, to the inch), or, in the case of receptacles kept in the house, with a covering of cheese-cloth, or

(iii) stocked with mosquito-destroying fish, or (iv) covered with a film of oil.

4. Any pond or pit containing water, situated in a town or within 150 yards of a human habitation, which is not stocked with mosquito-destroying fish or covered with a film of oil.

5. Any receptacle used for storing water, which receptacle may have been condemned as unnecessary under notice in writing of the local sanitary authority served or left on any premises in pursuance of the provisions of any regulations made under the authority of section 20 of Ordinance No. 13 of 1905.

And it is hereby declared that any collection of water shall for the purposes of these regulations be regarded as "stagnant water" if the same contains mosquito larvæ, or if the same has been left undisturbed for a period exceeding 18 hours.

Made by the General Board of Health, this 21st day of June 1909.

By order of the Board.

\author{
T. T. Dyer, \\ Clerk to General Board of Health.
}

3. Antilaryal Measures in St Vincent.

In St Vincent regulations were made, under Ordinance 3, 1901, dealing with larvæ destruction as follows :-

3. The occupier of any premises in any town, or in 
case of there being no person in occupation, the owner thereof, shall keep the premises free from stagnant water likely to breed mosquitos, and the presence of mosquito larvæ in any collection of water shall be sufficient evidence that such water is stagnant; and he shall also keep the premises free from tins, bottles, whole or broken (including broken bottles on walls), tubs, barrels, odd receptacles, broken crockery, etc., kept or left in a position likely to accumulate and retain water and so become breeding places for mosquitos.

4. Immediately upon any case of yellow fever or suspected yellow fever being reported, the Local Authority or Local Authorities for the district or districts in or near to which the case has oceurred shall make or cause to be made regular house-to-house visitation in their district in the vicinity of such place to ascertain whether any other cases of fever have occurred, and the Government Medical Officer of the district shall assist the Local Authority by examining any person the Local Authority may require, and the Local Authority shall see that, in any town, the provisions of the last preceding regulation have been, and are, observed, and shall also have power and authority to order and direct the owner or occupier of any premises in the neighbourhood of which any such case has occurred, and whether the premises be or be not in any town for a period of not exceeding three months from such order and direction :-

(a) To comply with the requirements of the last preceding regulation.

(b) To cover all openings except the draw-off opening in tanks, barrels, etc., used for storing water, with wire-gauze (not less than 18 mesh to the inch), or with a piece of cheese-cloth.

(c) To either cover and keep covered with a film of kerosene oil, or draw off and keep drawn off, or 
fill up, all pools, ponds, or excavations made for any purpose which may contain water.

(d) To disinfect in manner directed, or to oil once a week, any watery cess-pit, and to flush out or clean at least once a week any drain or gutter.

(e) To repair and free from obstruction any eaves, gutters, and down-pipes, and to keep the same repaired and freed from obstruction, so as to allow the free passage of water from the roofs of houses.

All persons shall comply with the orders or directions of the Local Authority, or of any inspector authorised by them in writing, in respect of any of the above matters.

5. The Local Authority, or any person authorised in writing by the Local Authority, is hereby empowered to enter any premises at any time between the hours of 6 A.M. and 6 P.M. for the purpose of enforcing the provisions of these regulations.

Made by the Governor in Council, this 8th day of May 1907.

$$
\begin{aligned}
& \text { V. F. Drayton, } \\
& \text { Acting Clerk of Council. }
\end{aligned}
$$

N.B.--By the provisions of section 21 of the Public Health Ordinance, 1901, any person who

1. Violates these regulations; or

2. Refuses or neglects to obey the same; or

3. Resists, opposes, or obstructs the lawful execution thereof-

is liable to a penalty not exceeding twenty pounds, or to imprisonment with or without hard labour for any period not exceeding six months. 
This year (1909) a new Bill is being prepared, to be called the Public Health Ordinance, 1909, containing provisions against stagnant water and mosquito larvæ. Provision is made for bringing water under proper control and supervision, etc.

\section{Antilarval Measures in St Lucia.}

The following useful notice has recently been issued to householders in St Lucia :-

1. In the general interest of the public health, and particularly to prevent the introduction and spread of yellow fever, which would most seriously affect the trade of the island, every householder is invited to co-operate with the Health Authorities in the destruction of mosquitos.

2. It is by mosquitos that yellow fever and the ordinary malarial fever are carried and spread.

3. Mosquitos can only breed in stagnant water, therefore you are requested to see that-

(a) Any tanks or jars or other water receptacles in your yard are screened according to the Board of Health Regulations, to prevent mosquitos getting into the water to breed.

N.B.-The Health Authorities will be prepared to examine premises and give advice as to the proper way of screening, etc. In Castries a specimen of such screening can be seen at the Police Station.

(b) All wells are filled up.

N.B.-Well-water in Castries is most unwholesome.

(c) None of the following articles are kept lying about your yard or lots :-

(1) Bottles, whole or broken. 
(2) Tins ;

(3) Broken pieces of earthenware ;

(4) Coco-nuts ;

(5) Calabashes ;

or any other thing capable of holding water.

(d) That all hollows in the ground about your yards or adjacent premises are filled up to the level, so that water may not collect in them.

(e) That water kept in

(1) Washing-tubs,

(2) Flower vases,

(3) Chickens' drinking-vessels,

is changed very frequently and the vessels kept free from moss, because the green moss found in such vessels harbours the mosquito larvæ and keeps them alive while the water is being changed.

Issued by advice of the Medical Board.

July 7, 1909.

H. A. Smallwood, Acting Colonial Secretary.

Examination of the Inspector's note-book gives the details of inspections and how the yards of the inhabitants of Castries are carefully examined for the presence of water receptacles, rubbish, and especially larvæ.

At first, the book shows that the inhabitants were cautioned against the dangers of stagnant water and harbouring larvæ. Finally, summonses were obtained. After regulations were passed making it an offence to harbour larvæ, the following prosecutions took place :-

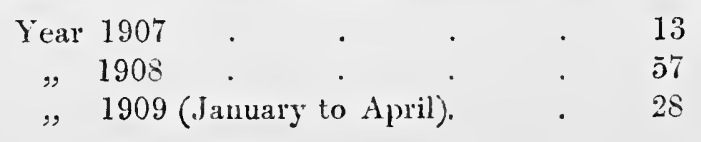




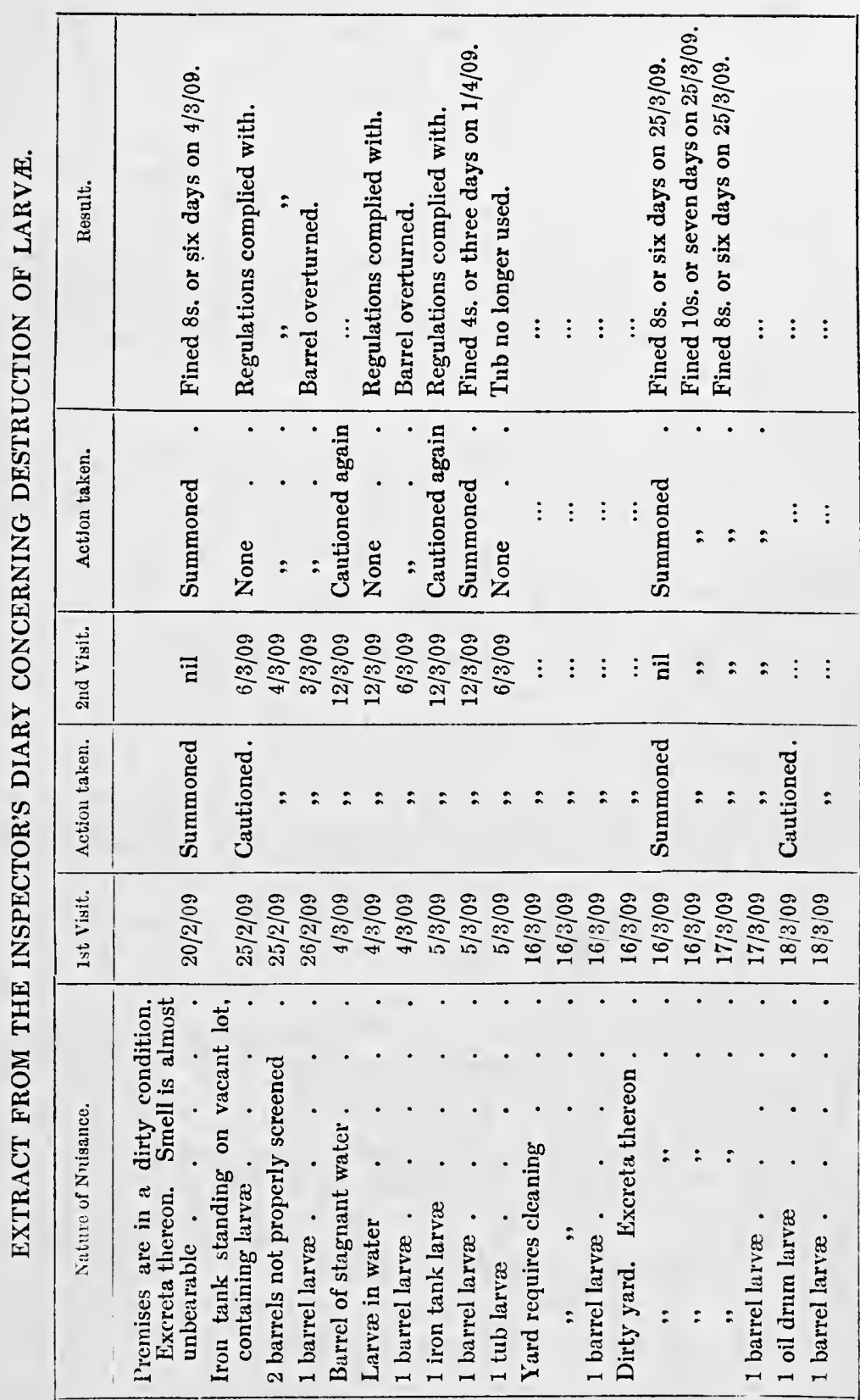




\section{Antilarval Regulations in Trinidad.}

In March 1907 regulations were made under section 8 of Ordinance 188, to deal with yellow fever by screening patients, fumigation, etc., and by prohibiting the keeping of stagnant water, unless properly protected. It runs as follows :-

(a) No water shall be stored (except in small quantities for drinking purposes) unless efficiently protected against mosquitos by the following method :-

All tanks, barrels, etc., for storing water shall have all openings except the draw-off opening covered with wire-gauze (18 mesh to the inch), or with a piece of cheese-cloth or fine mosquito netting, and all fountains, pools, ponds, antiformicas, or excavations made for any purpose whatever, in public or private property, which may contain water, shall be kept stocked with mosquito-destroying fish, or shall be kept covered with a film of petroleum oil.

(b) The occupiel or owner of any premises shall keep such premises free of stagnant water liable to breed mosquitos, and the presence of mosquito larvæ in any collection of water, wherever situated, shall be sufficient evidence that such water is stagnant.

(c) The occupier or owner of any premises shall keep his premises free of all articles (bottles, whole or broken, old tins, boxes, conch shells, etc.) which may letain water and so become the breeding places of mosquitos.

(d) All watery cess-pits shall be disinfected or oiled and all catch-pits cleaned out at least once a week.

(e) All eaves-gutter's and down-pipes shall be 
maintained in good repair and free of obstruction, so as to allow the ready passage of water from the roofs of houses.

(f) The Medical Officer of Health, or any person authorised by him in writing, shall have authority to enter any premises at any time between the the hours of 6 A.M. and 8 P.M. for the purpose of seeing that these regulations are carried out.

6. Any person failing to comply with these regulations shall be guilty of an offence and be liable to a fine not exceeding twenty pounds.

In the new draft Ordinance for 1909, provisions similar to the above are inserted for dealing with the breeding places of mosquitos.

Prosecutions - (Port of Spain Gazette, 6th May 1909).-For failing to keep their premises free from stagnant water liable to breed mosquitos, four persons were prosecuted at the City Police Court yesterday. In each case a conviction was secured, and the fine imposed 5 s. or seven days' imprisonment.

Return of Prosecutions under Antimosquito Regulations, from 1st April to 8th December 1909.

Total number of informations laid .

Number fined (all convictions, with one exception) $\cdot \cdot \cdot \cdot 152$

Number reprimanded and discharged

(The summons was served by mistake on the owner instead of on the occupier.)

Kind of receptacle in which larvæ were found:-

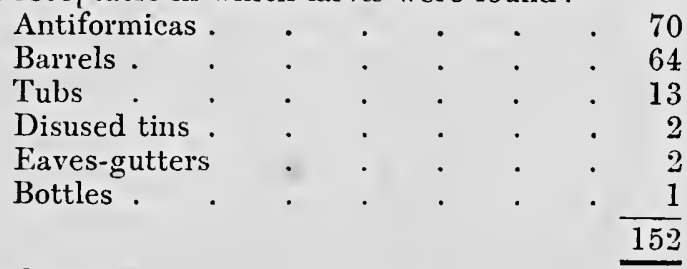


Return of Cases prosecuted by the Acting Sanitary Inspector for Breach of Regulations, under Order 188 of January 16, 1908.

\begin{tabular}{|c|c|c|c|c|c|c|c|c|}
\hline \multicolumn{3}{|c|}{ Date of Offence. } & \multicolumn{2}{|c|}{ Offence. } & \multicolumn{2}{|c|}{ Date heard. } & \multicolumn{2}{|c|}{ Juỏgment. } \\
\hline & Mar & ch 5,1909 & \multirow{2}{*}{\multicolumn{2}{|c|}{$\begin{array}{c}\text { Stagnant water in } \\
\text { barrels } \\
\text { Stagnant water in } \\
\text { barrels and tubs, } \\
\text { with mosquito } \\
\text { larvæ }\end{array}$}} & \multicolumn{2}{|c|}{ March 16,1909} & \multicolumn{2}{|c|}{... } \\
\hline 2. & , & 17,1909 & & & & 26,1909 & \multicolumn{2}{|c|}{$\begin{array}{l}\text { 10s. fine or } 7 \text { days' } \\
\text { imprisonment. }\end{array}$} \\
\hline 3. & Apri & 17,1909 & ,, & , & April & 23,1909 & \multirow{2}{*}{\multicolumn{2}{|c|}{$\begin{array}{l}\mathfrak{E 3} \text { or } 14 \text { days. } \\
2 \text { s. } 6 \text { d. or } 7 \text { days. }\end{array}$}} \\
\hline 4. & , & 20,1909 & , & , &, & 29,1909 & & \\
\hline 5. & & ", & , & , & , & ,' & , & , \\
\hline 6. & ", & 19,1909 & ", & ", & ,", & ", & ,", & ," \\
\hline 7. & , & , & , , & , , & , & ," & ," & ," \\
\hline 8. & ", & , & , & ," & ,", & ," & ," & , \\
\hline 9. & ," & ", & ," & ", & ," & ,", & ", & ,", \\
\hline 10. & ", & ," & ,, & ", & ,", & ," & ," & ," \\
\hline 11. & , & ," & ," & ," & , & ," & ,", & , \\
\hline 12. & ," & ", & ," & ", & ," & ," & , & ," \\
\hline 13. & ," & ,", & ,", & ," & ," & ," & ,, & ", \\
\hline 14. & , & ," & , & , & , & , & , & , \\
\hline 15. & , & , & , & , & , & ," & ," & ," \\
\hline 16. & ,' & , & , & ," & , & ," & ," & ,' \\
\hline 17. & ,", & ", & ," & ", & ," & ,, & ,, & ," \\
\hline 18. & ," & 21,1909 & , & , & , & , & " & " \\
\hline 19. & , & , & , & , & ," & ," & , & ," \\
\hline 20. & ", & $"$, & ," & ", & ," & ", & , & ,", \\
\hline 21. & ," & ," & ," & ," & ,", & ," & , & ,", \\
\hline 22. & ", & & ," & ", & ,', & ," & ," & , \\
\hline 23. & ," & 20,1909 & ," & ,", & $\ddot{\prime}$ & 9 10 &, & \\
\hline 24. & , & 22,1909 & , & ", & May & 3,1909 & $5 \mathrm{~s}$. or & days. \\
\hline 25. & , & 23,1909 & , & ," & ," & 5,1909 & ," & ," \\
\hline 26. & ," & ," & ," & ," & ,", & ," & ,", & ,", \\
\hline 27. & ," & ," & , & ," & ,' & ," & , & ," \\
\hline 28. & ", & ", & , & ", & , & 7 "'inon & ", & \\
\hline & , & 28,1909 & ", & ", & ,' & 7,1904 & E1 or & days. \\
\hline
\end{tabular}

Summary of Prosecutions from 5th March to 28th April 1909.

29 prosecutions for keeping stagnant water in barrels or with mosquito larvæ.

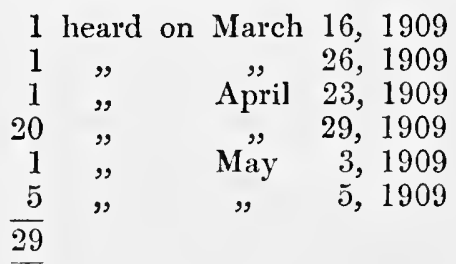

Convictions were obtained in all cases. 
In 1 case a fine of $10 \mathrm{~s}$. was imposed

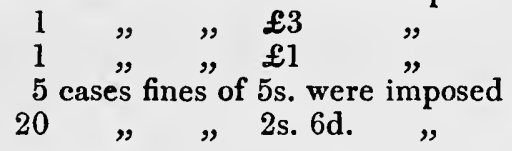

The fines were paid in all cases except that in which a fine of $£ 3$ was imposed. The defendant elected to go to prison for 14 days.

Total fines paid, $£ 5,5$ s.

\section{Antilarval Measures in British Guiana.}

The old Public Health Act not containing any reference to antimosquito measures, special bye-laws were enacted.

In 1905 a bye-law for the cleansing of tanks, without, however, special reference to larvæ, was issued.

In 1907 , bye-laws relating to the screening of vats, etc., as a preventative against mosquitos were promulgated, under the title "Mosquito Prevention Byelaws, 1907," as follows :-

Bye-laws Relating to the Screening of Vats, etc., as a Preventative against Mosquitos.

1. These bye-laws may be cited as the Mosquito Prevention Bye-laws, 1907.

2. All vats, tanks, or other vessels shall be screened with mosquito-proof wire-netting, or other suitable material, so as to prevent the entrance into or exit of mosquitos from such vats or tanks or other vessels.

3. The inlet and overflow pipes into such vats, tanks, or other vessels shall be placed in such positions or screened in such a manner as to prevent the entrance into or exit from the same of mosquitos.

4. All buckets or other vessels containing water for 
fire-extinguishing or other purposes shall be emptied and cleansed at least once a week.

5. The work of screening the vats, tanks, and all such other vessels shall be done by the owners of the properties on which they are situated, and all vats, tanks, or other vessels shall be screened within three months from the date of the coming into force of these bye-laws.

6. Any person contravening any of these bye-laws shall be guilty of an offence, and, on summary conviction, be liable to a penalty not exceeding ten dollars.

Made by the Mayor and Town Council of Georgetown, under section 179 of the Local Government Ordinance, 1907, and confirmed by the Governor and Court of Policy, on the second day of September 1907.

These do not appear, owing to considerable prejudice, to have been enforced. I had, however, the opportunity of discussing them with the Mayor and Town Council, with the result as follows:-

\section{Public Notice.}

\section{Vat-Screening.}

The Mayor and Town Council having directed that the Vat-Screening Regulations of 1907 are in future to be rigidly enforced, and the Sanitary Inspectors of the several wards having been instructed to notify property owners and householders accordingly, public notice is hereby given that all persons failing by the 15th July next to comply with such regulations in respect to the efficient screening of tanks, vats, barrels, and other vessels used for the storage of water, will be proceeded against as the law directs. 
Advice as to the best methods of screening to be adopted will be given when required on application at my office.

By order of the Mayor and Town Council.

Town Hall, Georgetown,

LuKe M. Hill,

Toun Superintendent.

June 8, 1909.

Note. - Correspondence in connection with the screening of vats in Georgetown :-

SIR,-In reference to your paragraph in this morning's issue about vat-screening in Georgetown, I may mention, for the information of the public, that many hundred vats have already been screened, notwithstanding your statement that only "a comparatively small number" have been so treated.

It may be of some interest to those property owners still in default to know that the following general order to town overseers was issued by me on Thursday :-

"As the days of grace allowed for vat-screening expire to-day, I shall be glad if the overseers will make out a return of all vats screened and unscreened in their respective districts, with a view of instituting some prosecutions of recalcitrant owners and occupiers, as an example to others; and to show that it is intended to enforce the vat-screening regulations.

"I expect these returns to be made from personal inspections of the storage vessels, and not from casual enquiries made from the householders.-I am, Sir, etc.,

"Luke M. Hill, "Town Superintendent.

"Tows HaLL,

.July 16, 1909." 


\section{Town Superintendent's Report.}

In the report of the town superintendent for July it is stated, inter alia, that vat-screening operations are still being busily engaged in all over the city, so that complete returns are not yet available, but up to the end of July it is computed from actual figures that 1300 vats are already screened, being about 35 per cent. of the total number ; but barrels and other small water receptacles, of which there are about 2500 , seem hopeless.

\section{Drainage Bye-Laws in British Guiana.}

By Ordinance 13, 1907, stress has been laid upon the necessity of drainage. The bye-laws are as follows :-

\section{Drainage Bye-laws}

For the city of Georgetown, in the county of Demerara, colony of British Guiana, with respect to the Drainage of Lots.

\section{Memorandum.}

The Public Health Ordinance, 1878 (now Local Government Ordinance No. 13, 1907), enacts :-

23. (174, New Ordinance 13, 1907). The owner, or, when required by the local authority, the occupier of every lot of land situate in a town or village district shall effectually drain the lot, and for that purpose shall :-

1. Make such dams and drains on the lot as may be necessary for effectually draining the lot;

2. Fill up all irregularities in the surface of the lot; and

3. Adjust the surface thereof, and if necessary raise 
the level of the surface thereof, in such a manner-

(a) That the water received on the lot may flow into the drains without obstruction;

(b) That no water can remain on any portion of the surface of the lot other than the drains ; and

(c) That the surface of the lot does not remain swampy.

Provided that where the swampy state of any lot in any such district is occasioned by the main drains into which the drains of the lot discharge not having a sufficient outfall or a sufficient capacity to carry off all the water discharged into them, the owner or occupier of the lot shall not be liable, under this section, to raise the level of the surface of the lot, if the!level of such surface is as high as the average height of the level of the land surrounding such a lot for a distance of twenty roods; and

Provided that any owner may, with the consent of the local authority of the district in which the lot is situated, have a pond on the lot.

\section{Antilarval Measures in Nassau. The BAHAMAS.}

Measures were first taken in $\mathbf{1 9 0 5}$ by the Board of Health against mosquito-borne diseases. In 1906 the authorities circulated my pamphlet upon the prevention of yellow fever, and imported wire-gauze for distribution. In 1907 the following useful antilarval regulations were drawn up and circularised, and quinine was distributed at cost price and free of cost to the poor. 


\section{Board of Health Act, 1872.}

\section{Rules and Regulations, October 1907.}

1. The owner or person in control of any cistern, vat, tank, barrel, bucket, or other vessel used for the storage of water, shall within such time as may be specified by notice, protect the same from mosquitos in the following manner-that is to say :-

I. Cisterns, tanks, vats, and barrels shall be provided with covers of wood or metal, and all openings other than the delivery exit shall be screened with netting.

II. Buckets and similar or other retainers shall be protected in the same way as cisterns, or in some other manner approved by the Board.

III. Owners and occupiers of premises on which there is any water in wells, ponds, pools, or basins, or in depressions or excavations made for any purpose, or which by any means have occurred, and in which mosquitos can breed, shall, within such time as may be specified by notice, protect the same from mosquitos in the following manner-that is to say :-

(1) Stock them with mosquito-destroying fish ;

(2) Or cover them with protective netting;

(3) Or drain them off at least once a week;

(4) Or cover them with oil at least once every week; or fill them up;

(5) Or (in case of wells) provide them with a pump and mosquito-proof cover to the satisfaction of the Board.

3. All empty and open tins shall be kept in such a 
position as to prevent mosquitos breeding in them, and all odd receptacles, such as jars, broken crockery, condensed milk tins, and other rubbish which form receptacles for water shall be removed and buried. All doreys, pit-pans, and boats, in use or discarded, must be kept free of fresh water.

\section{Penalties.}

4. Any person committing a breach of any of these rules and regulations shall be liable on summary conviction to a penalty of $£ 2$, and on a second conviction to a penalty not exceeding $£ 5$, or to imprisonment with or without hard labour not exceeding thirty days.

8. For Antimosquito Measures in British Honduras, see Appendix. 


\section{CHAPTER VIII}

TRADE ROUTES AND THE EXTENSION OF DISEASE

THE history of nations teaches us that extension of trade, and increasing intercourse between countries entail also the diffusion of disease. When the Conquistadores of the Old World, under Columbus and Cortes, set forth to conquer and exploit the New World, they carried with them some of the diseases common in Europe.

In their turn, they found themselves attacked by, to them, new and mysterious diseases, such, for example, as yellow fever.

From the evidence which I have examined, I conclude that this disease was in all probability endemic and universal amongst the inhabitants of the new world at that period: so prevalent and endemic amongst them, and probably of so mild a nature, that little attention was paid to it by the natives-much in the same way as the inhabitants of endemic malarial countries go about their daily avocation, although their blood may teem with the malarial parasites.

Similarly, we may with reason suppose that the native inhabitants of the newly discovered continent acted 
as the "healthy carriers" or ambulatory reservoirs of the yellow fever virus.

From this source the Stegomyia derived a constant and abundant supply of infection.

The new arrivals from the Old World were at once attacked by what was to them a new and mysterious disease, which in them produced the most severe symptoms. So severe a form, in fact, did the new disease assume anongst the newcomers, that it proved to be the natural barrier against the progress of European enterprise in the New World, just as malaria and sleeping sickness have kept back white enterprise in Africa. When at last a footing was obtained in the New World-albeit at a terrible sacrifice of life (as we know from historic records)-towns sprung into existence, and a constant intercourse was kept up amongst the various ports in Central and South America and the West Indies, as well as with the Old World, and subsequently with North America. Now it is precisely at the period of general maritime trade expansion that chroniclers record outbursts of yellow fever at places where the disease appears not to have been previously noted. Thus the ship Oriflamme is blamed for having introduced the disease into Martinique, the ship Hankey with having conveyed it to Grenada, and the ship Grand Zure with having brought it back to Spain.

Certain it is, however, that the period of commercial activity coincides with the diffusion of yellow fever over a wide area. Southern ports and towns in the United States became infected, due to trade with the West Indies and the Spanish Main. Spain, as one would 
expect, owing to its colonial possessions, was the first country to be severely affected in Europe. From 1700 to 1800 , disastrous epidemics swept through the southern portion of the Peninsula. Later, Portugal, Gibraltar, France, and even England were visited. But in Europe the conditions did not exist for the long persistence of the infection, and with the exception of a few imported cases, the disease soon died out. In the West Indies, and in certain Central and South American ports, a precisely similar change is taking place : the disease is becoming rarer as the Stegomyia mosquito is disappearing, owing to the new conditions of the water-supply doing away with the breeding places of the mosquito, and we can, with confidence, look forward to the time when yellow fever will be as unheard of in many of these places as it is in Europe at the present time.

A few endemic foci are, however, sure to hold out until they have been dealt with by the modern sanitary forces. Such foci are to be encountered along the Amazon, the Orinoco, and in certain other Central American states; but they, too, no doubt will disappear in process of time. To return to the effect of trade intercourse upon the diffusion of disease, we find yellow fever, for example, called "ships" or "sailor's" fever, the name "yellow jack" surviving to this day.

Ships have always been regarded as the worst offenders in the propagation of the disease. The Stegomyia not having been known in those days, it was thought that a section of the yellow ferer climate was conveyed in the ship from the infected port of departure, and dumped down at the port of arrival. 
In later times special kinds of cargo and the bilge water were in their turn accused. Thanks now to modern discoveries, we know that the explanation why ships did and may still carry yellow fever infection is very simple. The yellow fever mosquito-the Stegomyia calopus-can live as easily in the galley, forecastle, staterooms, and holds of a ship as in a house on shore. It is common experience now that when ships are moored alongside wharfs or pontoons, or stand a little way off from shore, when moored in the river or creek, that they are invaded by mosquitos-many of which may be infected.

Dr Grubbs of the U.S. Marine Medical Service carefully examined 82 vessels coming from Stegomyic infected ports. In three cases the Stegomyia was found, although the duration of the voyage was from thirteen to twenty days. Even if the adult Stegomyia is unable to gain access to the ship, the eggs and larvæ may be taken in with the drinking water stored in the caskis and tanks on board and these develop during the voyage.

To sum up, infected or non-infected adult Stegomyia may come on board at the port of departure. If infected, they will spread infection to all non-immune passengers and members of the crew whom they may chance to bite. The non-infected Stegomyia which have come on board, as well as those which have hatched out from the larre in the water on board, may become infected by biting a passenger or one of the crew, who may perchance be suffering from a mild attack of yellow fever; then, when once infected, they spread the disease 
throughout the ship. We have abundant and absolute proof that Stegomyia are carried by ships for very long distances. We also know that cases of yellow fever develop and spread long after a ship has left an infected port, and, if it has been proved, as has been done, that yellow fever is only transmitted by the Stegomyia, then what has been shown to occur on land can also occur on shipboard, provided the mosquitos are there. In the days of sailing ships, mosquitos were more frequently encountered on board than they are in the present-day iron steamers. The conditions have been completely changed: condensed water largely replaces barrel water; there is far better ventilation of the living quarters; and greater precautions are taken to prevent the access of mosquitos from the shore. The result is that "yellow jack" is the exception, not the rule, on ships trading in the yellow fever zone.

It has also been proved that the Stegomyia may be transported in baggage and in cargoes.

Again, it is well known that smallpox and plague are both frequently spread by shipping. It is, of course, for these common-sense reasons that the laws of quarantine have been established amongst civilised nations. We know that plague is peculiarly liable to be ship-transported, because of the frequency of rats on ships, and it is for these reasons that such stringent precautions are taken to prevent the access or egress of rats to or from ships when in port.

It is easy to understand that when large bodies of men stream from one point to another, whether on foot, by caravan, rail or ship, that they are liable to carry 
actual infection, or the insects which transmit the infection. It is the same, of course, in the case of the exportation or importation of animals and plants. In one of his works on Africa, Livingstone states : "Before the Arabs came, bugs were unknown; one may know where these people have been by the absence or presence of these vermin."

Writing of ticks, which transmit relapsing fever in man, Dutton and Todd state that ticks came into the Congo Free State from the East Coast with the Arabs; the ticks are found along much-travelled roads. So with the tsetse fly and sleeping sickness, the development of trade routes and intertribal movements are responsible for the spread of that disease in the central provinces of Africa. The pilgrimages to Mecca are other channels through which infection, plague, or cholera may readily flow.

From the home of plague, in India, that disease has steadily spread along the numerous steamship routes to the Far East, to the Pacific side of the American Continent, and through it to the Atlantic side, and then to the West Indies; to the East Coast of Africa, to the Cape, and then up to the West Coast; and from time to time a few cases are still imported into Europe. It is surmised, not without reason, that the decadence of ancient Greece was, in large measure, due to the importation of slaves who brought with them the malaria endenic from their African home.

Similarly, it is believed that malaria was introduced into Ismailia during the construction of the Suez Canal by the large bodies of Italian workmen, who were, in all 
probability, largely infected with malaria. Both in Greece and in Ismailia the Anophelines necessary to the extension of the disease were present. It is well known that malaria was prevalent in certain marshy districts of England in the seventeenth and eighteenth centuries, and it is possible that the slave trade and the employment of black servants, which was in vogue at these times, was not altogether unconnected with keeping up the supply of infection. Medical writers of the eighteenth and early part of the nineteenth century have many times described the horrors incidental to the slave trade, and have drawn attention to the danger of the slave-ship as a means of transmitting disease. ${ }^{1}$ In the days of the commerce in human beings, writers like Nicolas, Guérin, and Corre pointed out the prevalence of what was called negro lethargy amongst the imported slaves into the West Indies. We now know that this lethargy was, in fact, the sleeping sickness of to-day. The slave hunters of the period saw its disadvantage, and tried to get their slaves from districts reported free of the disease. The interest attaching to this importation of sleeping sickness cases into the West Indies lies in the fact that the disease did not take root and spread. It could not, for the simple reason that the tsetse fly is non-existent in the Antilles. For like reasons, malaria, which must have been carried into Barbados on countless occasions during the present and

1 Dr Audouard in 1824 tried to demonstrate that yellow fever was almost peculiar to slave-ships. That, in fact, yellow fever was the price which Europe paid for the slave trade, the outbreaks in Spain being attributed to the arrival of an old slaver engaged in the human traffic. 
past centuries, did not take root and become endemic. It could not, because of the natural absence of Anophelines. Considerations like these should bring home to everyone the practicability of preventing such diseases as malaria, yellow fever, and plague by the radical operation of destroying the insect-carriers. Viewed from this standpoint, tropical sanitation is one of the most hopeful and remunerative undertakings of the present century.

These considerations also show us the importance of exercising vigilance over trade routes and shipping. Observation and detention camps and quarantine methods cannot yet be discarded, although the discomforts incidental to them may in the light of modern discoveries be greatly mitigated. 


\section{CHAPTER IX}

HISTORY OF THE 1907-1909 OUTBREAK OF YELLOW FEVER IN BARBADOS

I ARRIVEd in Barbados on 1st March 1909, while an outbreak of yellow fever was passing through the island.

Origin of Outbreak.-Whence did it come? Was it the miasm from the dead of past decades again awakening to life? Or was it some foul emanation from a forgotten drain? Or had someone gone to reside in a house where in the past yellow fever had occurred?

One physician thought that any of these alternatives might have been the cause, and was prepared to bring much ingenious erudition in support thereof. At any rate, he was certain it could not be the mosquito, for, as he argued, the mosquito was not recognised as a cause by his forefathers, and in those days they knew all about yellow fever; therefore it was the miasm, because they said it was; but this physician had not heard of Beauperthuy of British Guiana, nor had he troubled to investigate what Manson, Ross, Carroll, Agramonte,

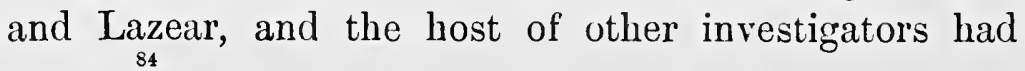




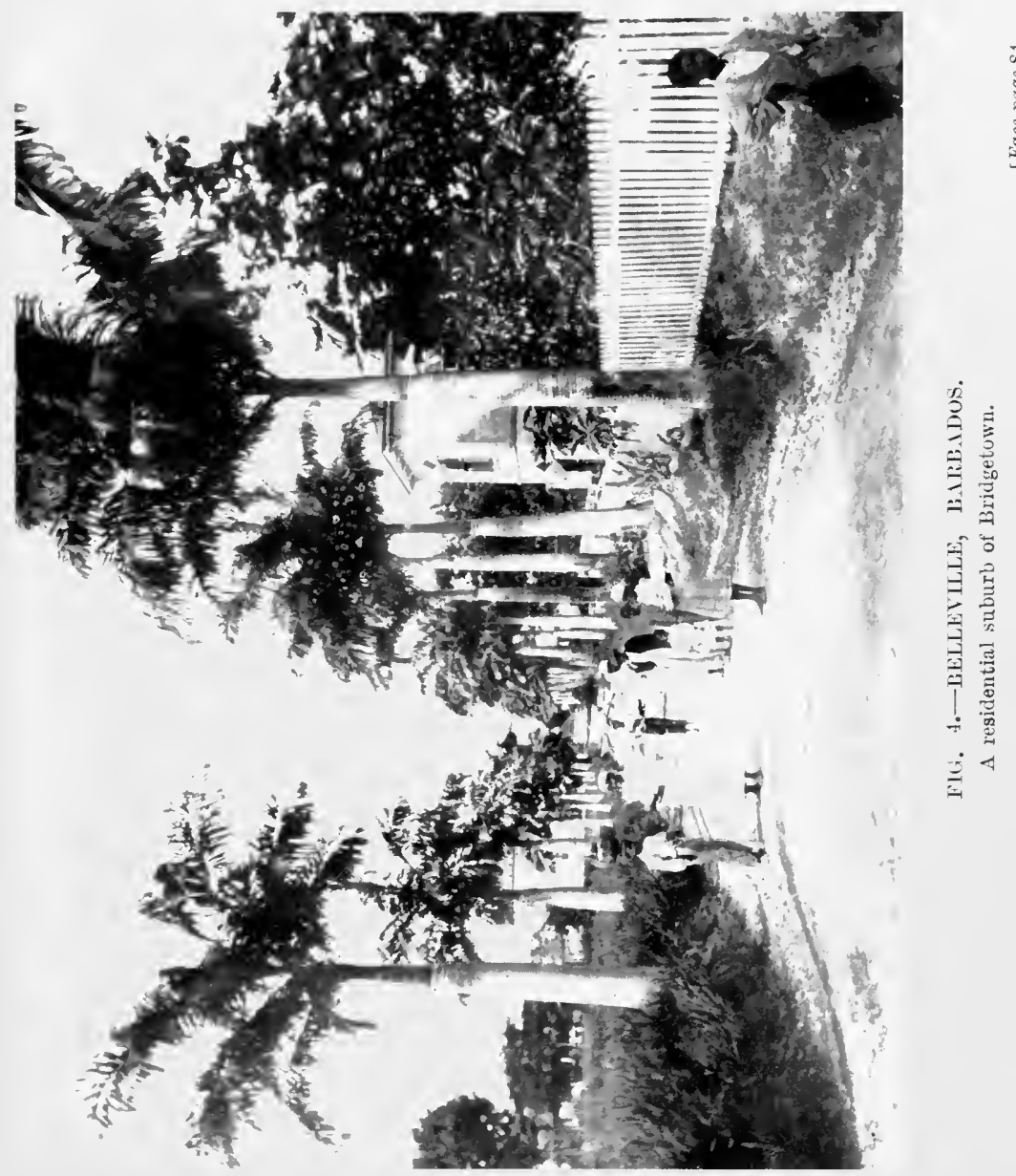



brought to light in the meantime. Miasm was, anyway, more fanciful, and allowed more play to the imagination and to conjecture, than a commonplace mosquito, about which everybody in Barbados knew everything that could possibly be worth knowing.

Previous Yellow Fever Epidemics.-Students wishing for information upon the past history of yellow fever in Barbados will find abundant material for study, buried away, not only in old army reports, but in almost any treatise or thesis upon yellow fever, so prevalent was it at one time in Barbados.

They will learn that yellow fever was to all intents and purposes endemic, with unfailing regularity appearing every year. Thus from the old records of the military medical inspector in Barbados we learn that the disease appeared for 40 years in uninterrupted succession. A table is given showing the months from 1815 to 1846 most liable to yellow fever, and so on, and so on ; for details see Chapter I.

One of the first epidemics of yellow fever occurred in Barbados in the year 1647 : at least so it is recorded by Ligon in his history of Barbados; and no less an authority than Humboldt states that it was present in 1691, and was known as Kendal's Disease, and was imported from Pernambuco.

Barbados was once a hot-bed of yellow fever, an endemic centre as bad or even worse than any other part of the yellow fever zone. The question then arises: Was the present (1907-1909) outbreak of yellow fever due to lingering infection in the island? Or was it imported from without? In my opinion, the evidence 
is conclusive, and is in favour of the latter view. The last epidemic was in 1881, and since that date new arrivals have not contracted yellow fever with the regularity and certainty that they would have done had the disease been chronic, smouldering, or endemic in the island.

We are obliged, therefore, to conclude that the infection which was responsible for the present outbreak was of recent introduction.

The infection, once introduced, whether in the person of an infected man or infected Stegomyia coming from the Amazon, the Orinoco, Martinique, Trinidad, or elsewhere, found the conditions in Barbados favourable for its propagation. The Stegomgia calopus was the common house-mosquito of Barbados, and was everywhere abundant when the infection was introduced.

I am, of course, well aware that in every clime, as Humboldt observed, "men fancy to derive consolation in the idea that a disease which is considered pestilential has been brought from abroad. This belief flatter's the national pride. To inhabit a country which produces epidemics might be deemed a humiliating circumstance, and it is more satisfactory to consider that the malady is a foreign one, and that its breaking out has been merely the effect of an accident, against which it will be easy to guard in another instance. The people immediately adopt this explanation of the disease because it is easily comprehended. The medical men, on their side, in general rest satisfied with it, because the word importation relieves them of all responsibility and from the trouble of investigating the 


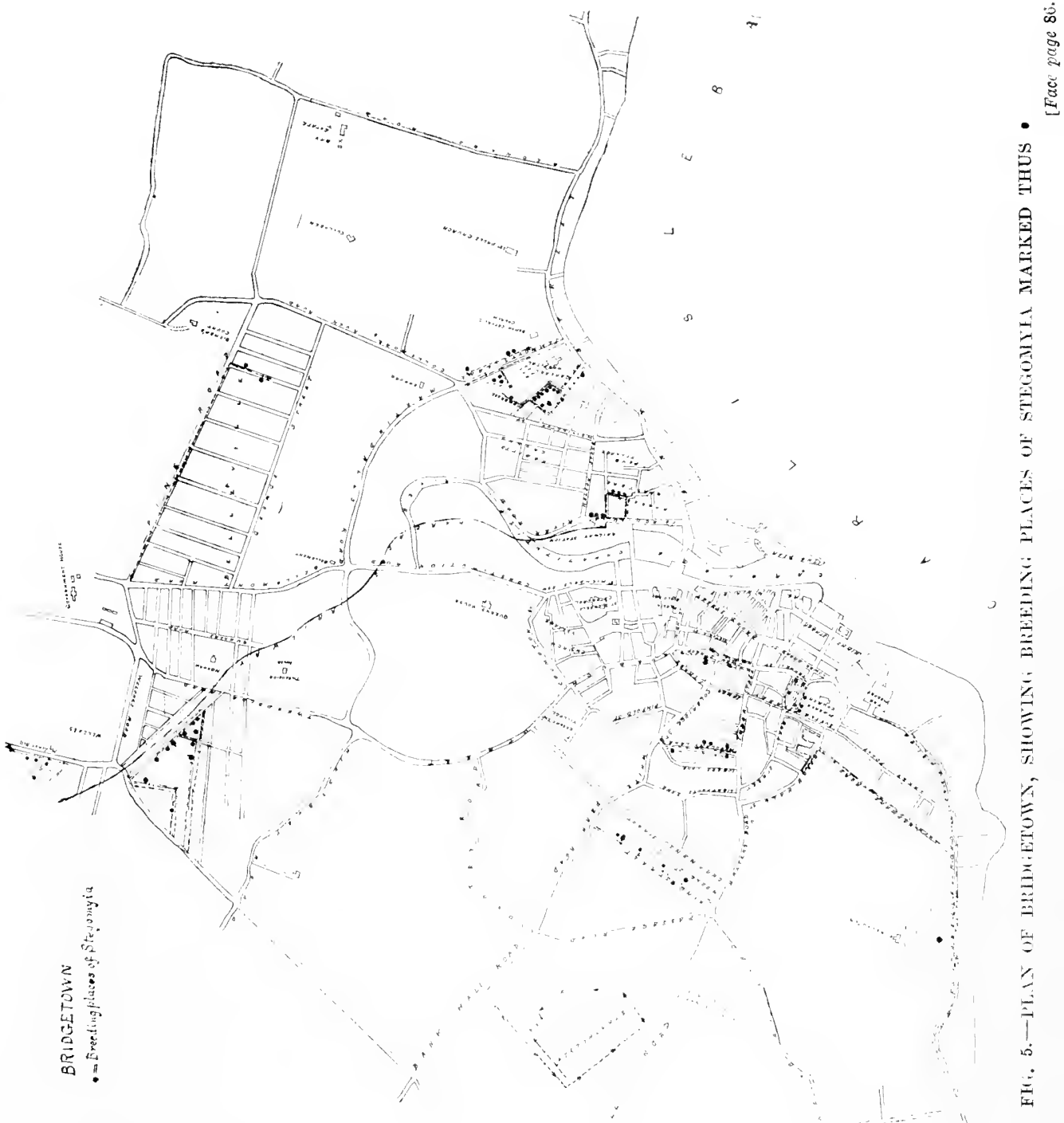



nature and real cause of the disorder." How like all this is to the reasoning which Barbados adopted, and, for that matter, which every country in which the pestilence has broken out in the modern period has likewise employed.

For it must not be forgotten that in the days of old it was the correct thing for the new arrival to get yellow fever and so become acclimatised, before he or she could be regarded as a real West Indian to the manner born.

Nevertheless, and in spite of the past history of endemicity, I am of opinion that Barbados was infected from without.

The following are the chief points of interest in connection with the origin, course, and cessation of the epidemic.

First Notification.-In November 1907 a group of seven cases were notified as yellow fever in Bridgetown. The first of these cases was notified on 19th November. The patient was the wife of the resident surgeon of the hospital, and she had been on the island eighteen months; the six others were sailors from H.M.S. Indefatigable.

H.M.S. Indefatigable arrived at Barbados from Grenada on 6th November 1907. On 18th November three seamen were admitted to the general hospital, and were found to be suffering from yellow fever, and were isolated. Maddocks, the first man taken ill, reported sick on board on 11th November, namely, six days after the arrival of the ship. These three seamen, and three others also affected subsequently, had all 
spent twenty-four hours on shore shortly after the arrival of the ship, and it was found on enquiry that they had spent the night in Rebbitt's Land, Bridgetown, which is behind and adjacent to the general hospital.

At 2 A.M. on the 19th-about twelve hours after the admission of these three men to the general hospitalMrs Alleyne, the wife of the senior resident surgeon, residing in the quarters of that officer at the hospital, died of yellow fever.

This clearly pointed to an infected area in the immediate vicinity of the hospital, and this area was at once subjected to daily inspection and special antimosquito measures-namely, fumigation, filling up or oiling of all collections of stagnant water-for a period of six weeks.

No case of yellow fever had been previously notified, nor was any suspicious case known to have occurred for a considerable time before this date. These cases occurred from the 19th to the 21 st of November. The next case was that of a German seaman, notified on 30th November, also staying in Bridgetown, at the Sailor's Rest. These patients were obviously infected in Bridgetown; we have no positive evidence that they brought infection with them. The doctor's wife had been residing eighteen months in Bridgetown, and the H.M.S. Indefatigable had not come from a yellow fever port, nor had there been yellow fever on board.

These cases constituted the first signal that yellow fever was present, and they show unmistakably that there existed in Bridgetown a considerable volume of infection - that is, that a very large number of Stegomyia must have 


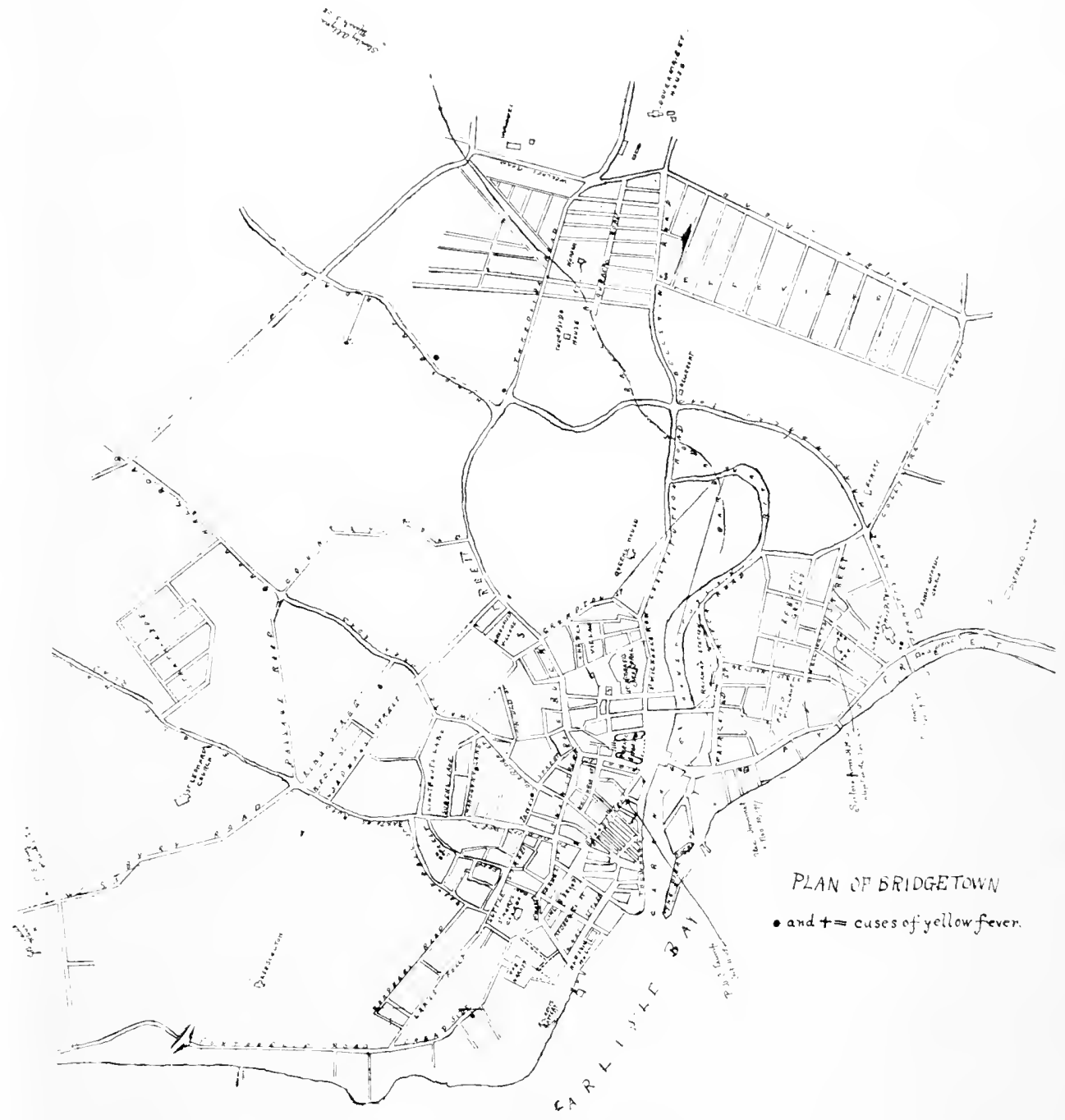

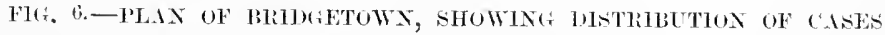
OF YELLOW FEVER. 

been infected-and that in all probability Bridgetown must have been infected previous to November : in other words, the outbreak occurred before November, but was, as is so often the case, unrecognised. The early cases were probably mild, and there being no reason to suspect yellow fever, they passed unrecognised. We know from experience that this is the usual course. These cases constituted, as Dr Hutson has said, the "bolt from the blue": the new arrivals were the sensitive index which showed at once that yellow fever was in the island; but as to the date at which it entered, we have at this lapse of time no reliable means of ascertaining.

Spread of the Epidemic.-The first cases to be notified, as we have seen, were in Bridgetown, in the parish of St Michael's. On 11th December 1907 "a case was notified in the parish of St John, and one in the parish of St Philip on 16th February 1907. A little later the infection had travelled round to the parishes of St Peter and St Lucy, the first case notified in the latter parish being on 29th December 1908. In this parish an outbreak occurred, some 29 cases being recorded. On 26th January 1909 the parish of St Joseph became infected, and a small outbreak also occurred, numbering some 18 cases. In the meantime (1909), scattered cases occurred in all the various parishes. The chief foci were, however, Bridgetown, in St Michael's; St Lucy; and St Joseph. The last case notified in St Michael's in 1907 was dated 21st November, and the first case in 1908 was dated 8th February, and was clearly due to the continuance of infected Stegomyia. From the middle of 
March to 11th October, when another case was notified, there was a curious cessation of notified cases of yellow fever. I cannot help coming to the conclusion that this apparent cessation was due to wrong diagnosis-in other words, there were probably cases of yellow fever, but they were not diagnosed as such. The result is that, starting from October 1908, there appears to have been a fresh outburst, not only in St Michael's, but throughout the island, due, I believe, in great measure, to more accurate diagnosis.

Cessation of the Epidemic.-Taking Bridgetown, in the parish of St Michael's, we have seen that from the first, recourse was had to fumigation and isolation, and no doubt the experience gained in 1907 and in 1908 led to increased efficiency in 1909.

With increased experience, it is seen, for example, how essential it is to notify cases at once, to isolate them, and, above all, to most conscientiously fumigate, in order to destroy infected Stegomyia. Experience showed the public that if the latter measures were not properly carried out, secondary cases were bound to follow in due course. That this was so, is clearly shown by comparison with the country parishes of St Lucy and St Joseph. In Bridgetown, St Michael's, the last case is dated April 1909, and I believe there have been no fresh cases since then. This date terminated the Bridgetown epidemic just when the "atmospheric conditions," as the old physicians would have said, were becoming more favourable for the spread of the fever.

It is clear that the early notification, more accurate diagnosis, and the isolation of the patient, coupled with 


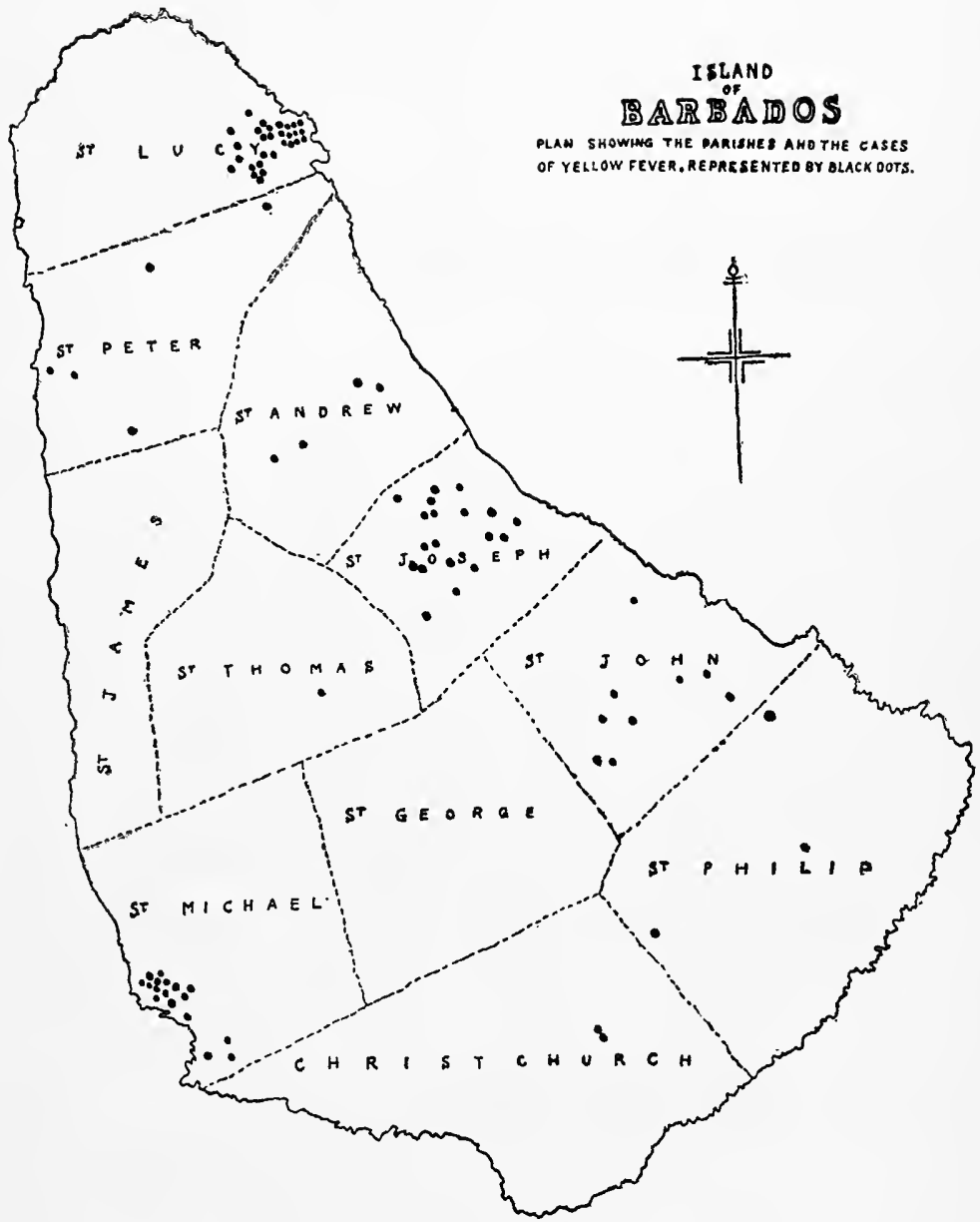

FIF. ‘- J'LAN OF BARBAINOS, SHOWING DISTRIBUTION OF YELLOW FEVER CASES. 

fumigation and larval destruction, had stopped the further progress of the disease in Bridgetown. But in the parishes of St Lucy and St Joseph, where the sanitary staff was not so large nor so experienced, cases were recorded well on into the month of June, and, in the case of St Joseph, into August. In my experience this is the usual occurrence: the epidemic is stamped out in the larger and better staffed towns and lingers on in the outlying villages.

The Board of Health recognised this, and therefore appointed a central inspector ( $\mathrm{Mr}$ Cumberbach) on 8th February, to supervise operations over the island. This inspector drew attention to the often faulty method of fumigation, and pointed out that all chinks and holes in the cottages were not always stopped up before fumigation. Of course it is difficult to seal the rickety wooden huts and houses of the poorer classes, but, as demonstrated repeatedly in Cuba and many other places, it is quite feasible with skill and patience to paper rickety shingle-covered houses so that it is impossible for infected mosquitos to escape.

Size of the Epidemic.-Reckoning from 1907, the total number of cases recorded was approximately 100 or a little over, or reckoning from the end of 1908 into 1909, some 86 cases.

It was a matter for comment that so many of the native black residents were affected, viz., 54 out of the total of 86. This simply indicates, as I point out further on, that the native residents were non-immunes, as an interval of some 26 years had occurred since the epidemic of 1881 -a period which allowed time for an 
abundant non-immune population to grow up. It shows conclusively that if the black race is protected from yellow fever, it becomes quite as sensitive to the disease as the latest arrival from Europe.

A considerable proportion of the cases occurred amongst children and young adults. Upon the 86 basis, the number of deaths recorded is 36 , equal to a deathrate of 42 per cent.

The Diagnosis of the Early Cases.-The question naturally arises: Do the notified cases represent the true total of all cases? In my opinion, the answer here is the same that has to be given in all these outbreaks : that in all probability there were many other cases which were not correctly diagnosed. There was a divergence of opinion amongst the medical men as to whether the cases were yellow fever or not, and the Press was not slow to make use of this want of unanimity during the outbreak; cases of illness were diagnosed as gastric influenza, epidemic jaundice, malignant jaundice, and dengue. Of course these diagnoses were made in absolute good faith by competent medical men; but for all that, there may have been mistakes, and some of the cases might have been yellow fever. I gather, from my conversations with the medical men, that this was indeed probably what did occur. I mention these difficulties because they invariably happen in practice, and because they demonstrate the absolute necessity of a medical head in the colony who, by virtue of his position, can, when he deems it advisable, bring about the formation of a friendly consultative committee of the medical men of the colony to act as a jury in matters of 
such grave importance as yellow fever. One man cannot know everything about every disease, consultative committees are therefore absolutely essential on certain occasions, and why not? Further, it is very disquieting to neighbouring colonies if, when a disease is diagnosed as gastric influenza, it leaks out that black vomit and a high mortality are characteristic of it. The neighbouring colonies, with the best opinion in the world of the good faith of the colony with such a remarkable form of gastric influenza, are nevertheless entitled to smile, and to insist upon rigorous quarantine measures; it is, after all, but business.

The Difficulties of Diagnosis from other Diseases.That the medical profession found considerable difficulty in diagnosis, the following memoranda amply prove :-

Mild Cases.-Extracts from the Quarterly Sanitary Reports of the parochial medical officers re yellow fever :-

Dr T. S. Brown, No. 1 District, St Michael, 31st March 1908.-During this quarter I have attended 29 cases of fever, lasting as a rule from three to five days: one case of yellow fever occurred in my district on which a postmortem was made, and it was duly notified. Several of these cases presented some symptoms of yellow fever, and I recognised them as those which in the epidemic of yellow fever in 1881 were called "tfebricula," and were then considered by the medical men who saw that epidemic, as very mild cases of yellow fever, as the initial symptoms were the same as those in which yellow fever afterwards developed. Some medical men have considered these cases to be "gastric influenza," but as no severe type of influenza was present while these cases occurred, I fail to see how "gastric influenza" can be 
associated with these cases. Further, if they were of the nature of influenza, we would have had thousands of these cases instead of the few cases that did occur, as the swiftly spreading and sudden invasion of influenza is well known. It should be noted that when cases of gastric influenza recently occurred in England, there was at the same time an epidemic of influenza of the ordinary kind, which affected the nasal and respiratory parts with which influenza is generally associated.

Dr E. G. W. Deane, No. 2 District, St Michael, 31st March 1908.-During the quarter several cases of gastric influenza have occurred in my district; in fact, I may say that we have had an epidemic of this disease.

Dr. C. E. Gooding, St Philip, 31st March 1908.-On 30th January, a boy named Hezekiah Sargeant was brought to the dispensary from near East Point. He had been ill for four or six days with headache, pains about the body, particularly the stomach, fever and persistent vomiting, and this for the previous twenty-four hours had consisted of a dark fluid like "coffee grounds." The boy looked very ill indeed, lying in a state of stupor, noticing nothing, and had to be roused to answer questions. His eyes were tinged with yellow, temperature $108 \cdot 6^{\circ} \mathrm{F}$., pulse 72 . He had characteristic "black vomit," without any effort marked tenderness in the epigastrium, and his urine contained about one-third of albumen. As his case was a typical one of yellow fever, I sent him back home, and got Dr John Hutson to see lim with me the same afternoon, when he concurred in the diagnosis, and the boy was sent to Pelican Island early next morning, where he subsequently died. A couple of days after, his brother, John Sargeant, developed similar symptoms, and, along with a little girl living in a neighbouring house, was also removed to Pelican Island. On 15th February I saw another 
typical case of yellow fever, in a girl named Clemintina Cordeaux, living near Well House (who afterwards died). She was also seen by Drs Phillips and Boxill. Since then I have sent two other cases to Pelican Island. . . . A few days after there were two suspicious (mild) cases in Alleyne's house in Garnes Land. Since that date, I am glad to report that no fresh cases have been met with.

Altogether I have met with five typical cases of yellow fever, with every cardinal symptom well marked, and three suspicious cases. . . . Of the five typical cases, the diagnosis of two was agreed to by Drs Hutson, Phillips, and Boxill. Four were coloured and one white.

Four were sent to Pelican Island, where one died, and I think I am right in saying that a different diagnosis was there made in all the cases.

The following very interesting account of gastric influenza has been kindly furnished me by a consulting physician residing in Barbados :--

Gastric Influenza.-The term "gastric influenza" has been applied by some medical men in Barbados during the last year to cases which other medical men regarded and notified as genuine yellow fever.

I say this without hesitation, because one man saw two cases and another man one case in consultation with me, which were all regarded by two other men and myself as undoubted yellow fever. These were all fatal in from three to five days in white persons, with early albuminuria, lemon-coloured urine, suppression of urine, black vomit, and yellow discoloration of the bodyslight during life, and pronounced after death. One of these cases was verified by a post-mortem examination, which revealed a typical "box-wood" liver, stomach showing arborescent congestion and containing black fluid. Other fatal cases characterised by "black vomit" 
were heard of from time to time, which were not notified, and which were commonly spoken of as "gastric influenza."

One merchant reported that he had private information of cases exactly similar which had occurred in Liverpool, and another merchant had information of cases seen by his son in one of the London hospitals which his son informed him were identical with the Indefatigable cases he had seen here. The general public believe that "gastric influenza" was a separate disease, hardly distinguishable from yellow fever, which required a high degree of medical skill to diagnose, and that the medical men who were diagnosing yellow fever were ignorant fools, or worse.

The following extract from a letter of a medical friend in a neighbouring island is interesting. $\mathrm{He}$ says :-

We are disquieted by the numerous reports we have from Barbados. I understand from letters that the laity there freely laugh about the new name for yellow fever.

We hear that gastric influenza is usually or always fatal, and always has black vomit. We learn that it is rather widespread in the island. We can do nothing to prevent its introduction again, after our successful efforts to keep it down so far.

Epidemic Jaundice, Weil's Disease. - Dr F. F. M'Donald, who has had the advantage of personal experience of this disease in Australia, furnished me whilst in Barbados with the following notes regarding this disease. Dr M'Donald's experience of epidemic 
jaundice, or Weil's Disease, was gained during an epidemic which passed through a camp of 5000 people in New South Wales. The chief symptoms were: acute fever, of sudden onset; lumbar pain; vomiting; abortion in pregnant women. There is often considerable mortality. The disease may be very sudden, and has suggested such diagnosis as toxæmia, hæmorrhagic septicæmia, uræmia. Its epidemic character, high temperature and slow pulse, together with vomiting and jaundice, make it liable to be confused with yellow fever.

Malaria.-In Barbados, unlike in other yellow fever countries, a difficulty of diagnosis between yellow fever and malignant types of malaria did not arise.

Dengue and Dandy Fever.-This fever did, however, cause considerable difficulty in diagnosis, and from my conversation with medical men, there can no longer be any doubt that cases which were diagnosed as dengue fever were, in reality, cases of yellow fever.

Early Notification: Timidity, Prejudice, and Opposition.-As in my British Honduras report, so in this one, I seriously direct attention to the difficulties of early notification. These difficulties have been encountered in an aggravated form in British Honduras and in Central and Southern American ports generally. There is no question in my mind that a considerable amount of odium is liable to be incurred by a medical officer who has the courage to declare a case of yellow fever.

This unsatisfactory state of affairs is often owing to the fact that there are usually to be found medical men who, without having themselves examined the particular 
case, nevertheless make up their minds that it is not yellow fever, but some other simple disease, of which they have had in their practice many cases. This gives the Press an opportunity, if so minded, to vilify the first medical officer who notifies, and even to hint that he knows nothing about the disease, whilst at the same time lauding the particular medical man who has given the opinion which is the more palatable, and therefore probably more in accord with the views of the newspaper. These tactics constitute a veiled form of intimidation, and are destructive in the long run to the reputation of any colony for fair play and honesty.

It is with very great regret that I am obliged to state that there was considerable opposition encountered in Barbados from a particular section, directed to thwarting and ridiculing those who were acting in the very best interests of the community by insisting upon early notification of suspected cases.

Whilst in British Honduras in 1905, I observed the same spirit; but I had expected a more enlightened policy from the Press of Barbados, as in the meantime an enormous stride had been made in tropical sanitation, and I expected an enlightened Press to have kept up with the development. Unfortunately the analysis of the articles in one particular journal, published in Barbados, shows, as will be seen, a retrogressive attitude, and one, moreover, which cannot fail to do harm to the reputation of the colony for progression, especially as in the West Indies there is more than one rival for the tourist traffic, besides competitors for the coaling and other trades. It might be argued, as it was done in 
this case, that the journal in question was a quantité négligeable and did not represent any body of opinion. That may be so : I can most certainly say that I found all classes of society, and notably the poorer people, exceedingly desirous of helping in every way. It was one of the greatest elements of encouragement which I got during my stay. But that there should still exist in a colony which desires to come up-to-date, not only a reactionary newspaper, but one which discourages the modern methods of prophylaxis, and even goes further and heaps up ridicule upon and even threatens medical men who do their duty, thereby using a system which flavours of intimidation, can only be regarded as a calamity, for it is calculated most assuredly to undermine the reputation for honesty in the matter of immediately notifying all cases of a quarantinable disease. In consequence, adjacent colonies receive with some degree of doubt the statements from Barbados-a matter to which I shall again have occasion to refer.

Opinions will always differ, as I have already stated, as to the diagnosis of the earliest and mild cases in epidemics of yellow fever and probably in all fevers; for this reason it becomes imperative for every colony to possess a medical head who can summon to his assistance, if necessary, a trustworthy group of medical men, who will act as a consultative board. Had this been done in Barbados, that colony would have saved many thousands of pounds and much waste of life. Those who have had experience in yellow fever know the difficulty of diagnosis in the early stages, so that there is no stigma attaching to the medical man who fails to 
diagnose a case. But from the point of view of health administration, it is in the doubtful mild cases where the greatest care and judgment is necessary, and the best way to meet the contingency is to have a principal medical officer and a consultative emergency board.

A more serious difficulty in the way of early notification is the odium which is too apt to attach to the medical man who diagnoses such serious diseases as yellow fever, smallpox, or plague. Popular opinion in a colony is against admitting that any such diseases are in their midst. Experience throughout the world, and from the earliest times, teaches us that this is so. Moreover, the bias of the commercial man of any town would be against admitting that such diseases are present. It is for this reason that it is a questionable advantage to have too many laymen upon health and quarantine boards. Where there is no P.M.O. they are, in my opinion, a positive danger, because, with the very best intentions, laymen are quite unable to assess the difficulties which must arise in questions involving early diagnosis amongst medical men, and they are naturally inclined to favour a policy which keeps the commerce of the port open and unrestricted. It is still more disastrous if the newspapers of a colony take sides and by innuendo and fomenting public opinion tend to bring discredit on those who, having the courage of their opinions, venture on such a momentous diagnosis as yellow fever, plague, or smallpox. A young practitioner or junior medical officer of health is unquestionably apt to be deterred from the execution of his duties by the stirring up of such popular opinion. 
In Barbados we have positive evidence, in the form of a series of articles which appeared in one particular journal, that this hostile opinion did exist during the recent epidemic. I append the following examples, so that in future, colonies may, in the interest of public health, avoid this most insidious evil and intimidatory policy.

A boy, Sergeant, was suffering from a suspicious illness ; there was a difference of opinion amongst the medical men who attended the case, and one of them ventured to diagnose yellow fever, and this is how he was regarded in the eyes of more than one newspaper :

"The Agricultural Reporter," Saturday, 8th February 1908. - The result of the enquiry conducted by $\mathrm{Dr}$ - the health officer, and $\mathrm{Dr}$ - into the cause of death of a boy named Sergeant, who was sent to the Pelican Island Hospital from Golden Drive, St Philip, by Dr _- , on Friday, 31st January, and who died there on the night of the same day, is to the effect that toxæmia was the cause of death. The case was not one of yellow fever. Dr —, although not com. missioned to take part in the enquiry, obtruded himself and fought hard to get the case declared one of yellow fever. Fortunately, the commissioned officers were not plastic tools in the hands of this alarmist and quarantine-monger.

Again, we read in the Barbudos Bulletin of 8th February 1909, under the heading "Arrogant Pretensions":-

The overweening self-importance, the arrogant pretensions of this functionary, $\mathrm{Dr}$ - - , have time and again, ere now, been paraded in the public press, but the particular incident which prompts this article, 
and which seems to cap the climax, took place on Wednesday last. On that day, as was mentioned in yesterday's bulletin, a Medical Board consisting of Dr —, Dr — , and Dr —, met to investigate the cause of the death of a man named Sergeant, a resident at East Point, St Philip. We presume it will be readily admitted by all persons, that the names here given suffice to indicate this Board to have been a thoroughly competent one to deal with the question at issue. Not so, however, thought "____," alias Dr _ _ _ - ; for, all-uninvited, he arrogated to himself the right to sit on this enquiry, take part in the deliberations, and even to pit his medical lore, singlehanded, against that of his three confieres combined; for while they declared the case to be one of jaundice, he discovered that it was yellow fever. A few days previously he had, in opposition to the opinion of another medical man, made a similar discovery or invention with respect to another case on which he had sat in judgment, and the neighbouring colonies were notified to that effect.

Now, we have not the remotest desire to witness any imitation by our Government and Health Authorities of the dishonourable policy adopted in such matters by Trinidad, and which has been so severely denounced here, and indeed throughout all the West Indies. If it be the will of Providence to afflict us with a real visitation of yellow fever or any other epidemic, the chastisement will doubtless be accepted by all classes without murmur or complaint, despite any inconvenience or suffering it may entail upon us; and for the national honour we would advocate a prompt notification thereof to all parties concerned. But in view of the magnitude of the evil involved, the importance of the interests at stake, we must certainly protest with all vehemence we can command against this extravagant presumption on the part of Dr —-, who appears not only to claim to himself the right of laying this colony under quaran- 
tine, but also seems possessed of a consuming desire to put that prerogative into operation. In the words of the Egyptians to Pharaoh, when they complained of the stubbornness of their king in refusing to accede to the demands of Moses, by whom the ruin of their country was being steadily wrought, we ask with reference to this consummate crank and faddist, who seems bent upon ruining the trade of the colony : "How long shall this man be a snare unto us?" How long shall we be exposed to the risk of being placed under quarantine at the ipse dixit of a Sir Oracle, the opening of whose mouth must be accepted as the signal of immediate and absolute silence on the part of every one? Problems that involve the welfare of a whole community are generally found to be very difficult of solution; but fortunately for us, the present one, though of such great importance, is capable of a very easy settlement. The office that rejoices in the grandiloquent title of Poor Law Inspector, is, and has always been, naught but a sinecure, and its immediate abolition would, we feel convinced, extort from no one save, of course, its present incumbent, a rending of garments or gnashing of teeth. We would therefore earnestly counsel the powers that be to lose no time in striking it out of existence, and sending this evil genius of ours to earn his livelihood as a private practitioner, in which position he would probably not have so much opportunity to gratify the insane ambition by which he seems to be possessed, of being the principal agent in working out his country's woe. More anon.

The medical man whom the newspaper asks the authorities to lose no time in getting rid of, is the gentleman who, owing to his experience, was deputed by the Board of Health on Jan. 6, 1909, to make an investigation into the sanitary conditions of the island, and whose report was the only official statement of the 
epidemic with which I was furnished by the Government of the colony and by the Colonial Office. Yet, because he ventures to make what appeared to be an unpopular diagnosis, he is threatened with grave penalties!

In the leading article of the Agricultural Reporter of 11 th January 1909, the following occurs :-

The parish of St Lucy referred to above, is apparently a gross offender in the matter of this yellow fever, and the Board of Health would seem to be disposed to make an enquiry into the state of affairs up north. But what is surprising is to find the Board commissioning $\mathrm{Dr}$ —— to go up there, enquire into the sanitary conditions prevailing, and to make suggestions for improvements. This makes one doubt the sincerity of the Board of Health. No doubt this learned little man will make a voluminous report and display a vast deal of knowledge. But, in view of his well-known predisposition to perceive yellow fever, copious recommendations, numerous feats to be performed under supervision of medical men, the expenditure of thousands of pounds, and the result, as is usual with Dr _-'s schemes and plans-Nil. The Board of Health should know this. Our advice is that Trade should make a truce with Medicine. European and American visitors on the island are not at all alarmed. Why need they be afraid of a yellow fever that prefer's the blacks to the whites?

The Agricultural Reporter of 22nd January 1909, in its leader on the outbreaks in the parish of St Lucy, states :-

For some time past there has been a disposition on the part of a section of our medical men to 
discover yellow fever. To this end, diseases which other medical men have recognised and diagnosed as of a different kind, have been declared to be yellow fever by the industrious discoverers. Despite their best efforts, however, the disease would not catch on. It would not become epidemic. It would not attack and kill a sufficient number of people, and so become a respectable and profitable disease until it reached the northern parish of St Lucy. There the disease behaved in a sufficiently malignant manner to win the approval of the pro-yellow fever party.

It is alleged to have attacked some 24 persons, and killed 7 of them. This meant that the business had sufficiently developed to attract special attention from the General Board of Health. And, of course, the first thing that this authority thought of doing was to commission $\mathrm{Dr}$ - to go down to St Lucy and enquire into the situation.

Comment upon the injury which articles of this nature are likely to produce in the minds of the poorer and more ignorant classes is useless. A real injustice is done to the sanitary reputation of the colony, and the good name of the colony in other directions is also bound to be affected. In my opinion, these newspaper articles constitute the only black cloud in the history of the 1907-1909 epidemic in Barbados, and it is earnestly to be hoped that a more healthy, honest, and mutually co-operative spirit will prevail in future, and that the Press will do all in its power, by means of reasoned articles, to show the world what a beautiful and healthy island they possess.

Complaints by other Colonies of the Tardy Notification of Yellow Fever hy Barbados, etc.--Both British Guiana and St Lucia drew the attention of the Barbados 
administration to the dangers to which they were exposed by the failure of Barbados to notify at once. The answers which were received, as I point out in the chapters dealing with British Guiana and St Lucia, were not calculated to allay their fears. They served, however, to reveal the lack of medical organisation in Barbados.

Race Incidence.-The fact that yellow fever attacked the coloured and black population with more frequency than the white, caused much surprise. As I have previously stated, this is not surprising, for, where yellow fever breaks out anew after a long period of absence, all members of the community, irrespective of colour or race, are equally liable. This fact showed that Barbados had been singularly free from yellow fever for many years. The black population has also suffered in the recent epidemic in Martinique, and in the days of Blair it also occurred, but, of course, with less frequency, as then yellow fever was much more endemic or chronic than it is to-day. The outbreak which has just gone through Barbados, had it taken place in the old days, would have seized all newcomers without exception: that is to say, all the non-immunes. Of course, the children of the black and coloured population would also have got it, but, no doubt, it would have passed unrecognised in them, as does to-day malaria in the natives in those countries where malaria is endemic.

In order to show the striking contrast of the recent outbreak of fever in Barbados to what happened in the days gone by, it is recorded that, in 1805 , the 15th Foot Regiment, in about three weeks, soon after their 
landing in Barbados, lost 110 men and 7 officers. In 1821, we read that 55 soldiers and very many of the crew of the frigate the Pyramus were admitted into the naval hospital, suffering from yellow fever. In 1841, we learn that 21 men of the 33rd Regiment died in the regimental hospital from 1st October to 15th December. Sometime about 1847, the 88th Regiment suffered severely after a year's residence; the 66 th after a few weeks, and the 72nd after about ten months' residence; the natives, on the contrary, not appearing to suffer-of course not, as they all had had it one time or another, and had kept up a constant supply of infected Stegomyia, which, sooner or later, were bound to have opportunities of biting the non-immune soldiers. Stronger evidence of the mosquito origin of the disease could hardly be conceived. By no other means could the difference of the recent and past epidemics be accounted for.

Periodicity of Epidemics.-Another subject which came up for comment in connection with the recent outbreak, was the question of periodicity. The authorities seemed to realise that it was time to have an epidemic, as epidemics in the past appeared to have occurred at regular intervals. There is absolutely nothing in it, however, though the older writers noted it. Thus Dr Pavy, editor of Blair's Work, observes: “A belief, founded on partial experience, commonly prevails in the West Indies, that the outbreak of yellow fever there is periodic. Its recurrence at intervals of time may be considered as well established; but it cannot be admitted to be equally well established that the 
intervals are regular and alike so as to admit of being calculated." In those days the idea was that a traveller would calculate when such and such a yellow fever country was due to have its outbreak, and when, in consequence, it would be unsafe to visit it.

The Season of the Year in which the Outbreat occurred.-The season may be summed up as the cool season; in this respect the recent outbreak resembles previous ones, when the disease was ever recurrent; it was years ago observed that the fever most frequently broke out at a time when the season was most agreeable and favourable to health. Again, this is clearly shown in the recent epidemic, for the general death-rate per thousand, viz., 10.9, was lower than in any of the previous years.

Nature of the Measures adopted to Check the Outbreak. - It having at last dawned upon the Barbadians that they really had yellow fever amongst them, in spite of the many reluctant growls, let us enquire what was done to meet the emergency which had arisen.

In the first place, the health authority of the island having no executive medical officer, no medical officer of health whose business it is, as in all civilised countries, and in all other British Possessions, as far as I am aware, to report regularly, and to investigate all outbreaks of disease, asked on the 6th January 1909 a member of their Board if he would be good enough to visit one of the parishes, St Lucy, in which an outbreak of yellow fever had occurred. Dr Hutson, the gentleman who volunteered, made a report (see Appendix), 
pointing out the weak places in the defences and making recommendations of a very useful kind. This very patriotic action of $\mathrm{Dr}$ Hutson and many subsequent similar acts, instead of earning the grateful thanks of the whole community for his having at once volunteered to assume the rôle of what the Board should have had, viz., a properly salaried medical officer, earned for himself instead, as we have seen, bitter abuse of a not unimportant section of the Press of the island. When I arrived in Barbados on March 1st, Dr Hutson's report was the only reasoned document which the Board of Health placed in my hands concerning the outbreak. No detailed investigation, as far as I am aware, was made into the origin of the outbreak, first officially declared 19th November 1907-that is, more than a year previously. I was not furnished with any detailed and completed report, which would have been of great use to me in my investigations. This situation undoubtedly discloses an extraordinary state of affairs-the total lack of a medical head for the colony. In the twentieth century it is hard to realise that a Legislative Council would have rested content without a medical adviser, especially in view of the fact that they had numerous excellent law advisers, and that by having a medical adviser they would only be following the rule of every civilised community throughout the world.

Had there been such a salaried officer, I am convinced that just as in the case of St Vincent and Grenada, the fever would have been suppressed at a much earlier date, and very much more money saved than that represented by the salary of such an officer. 
Further, however, as Barbados is naturally a most healthy island, it was, in my opinion, incumbent upon the Legislative Council to keep that reputation up and to publish it to the world, for much of the prosperity of the island depends upon its sea trade and its attractiveness to visitors seeking health and rest. Does anyone in their senses suppose that health resorts like Brighton, Eastbourne, Ramsgate, or Margate would tolerate the abolition of the posts of Medical Officers? They know that upon them naturally rests in very large measure the responsibility of the health security of these respective health resorts, the attractiveness of which is very largely due to their energy and vigi- . lance. Similarly, Barbados has everything to gain by appointing a well-qualified Medical Officer of Health, whose presence in the island would co-ordinate medical institutions and opinion, and who would be ready to advise as to all necessary sanitary reforms; above all, whose reports and ability would be a guarantee, both to business men and the travelling public, that Barbados is being properly looked after. Laymen cannot take the place of gentlemen who have been trained in medicine and sanitation, any more than medical men could be expected to decide and advise on matters of law or religion. Without such a duly qualified Medical Officer of Health, Barbados will, in my opinion, not only do itself injustice, but will positively injure its reputation; the recent outbreak is overwhelming proof of this. I sincerely trust, therefore, that the Legislature will, as a first step towards striving to keep Barbados the premier health resort of the West Indies, make this 


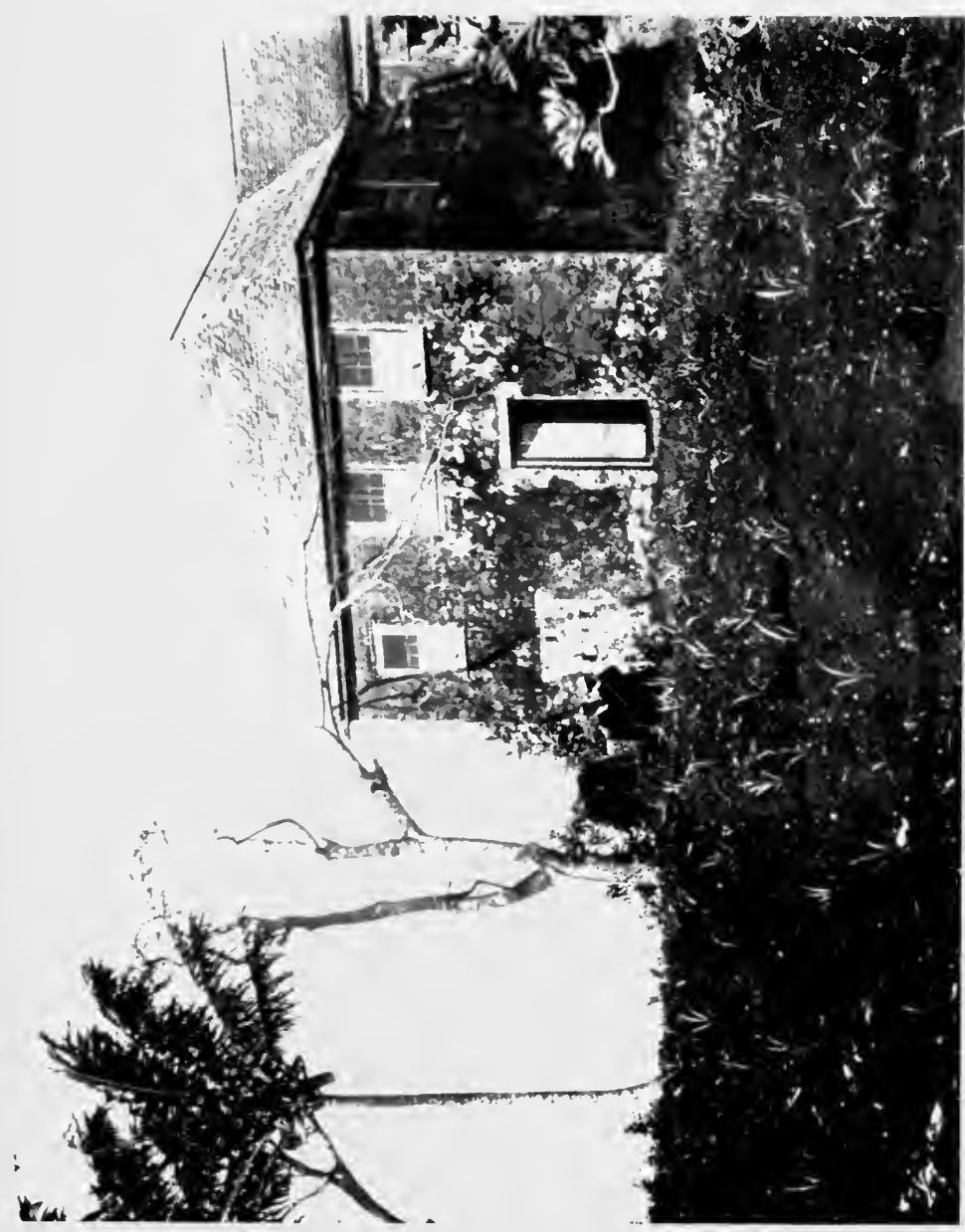

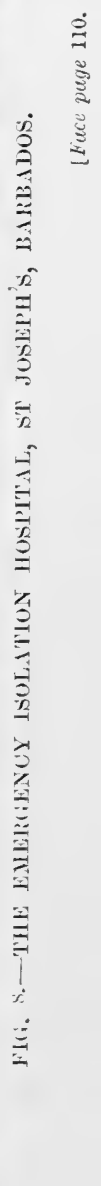



appointment. This is not my view only, it is the opinion of all those who have considered the question.

There having been no medical officer when yellow fever was declared, what steps were taken to grapple with the situation?

On 4th January 1909, a circular (see Appendix) was issued from the Board of Health to the Commissioners of Health of the various parishes, drawing their attention to the necessity of early screening, isolation, fumigation, early notification, careful surveillance of contacts and destruction of larvæ. All very good if only a medical officer had been there to see that they were done. On 14th January another circular was sent out, limited to the parish of St Lucy, forbidding wakes.

On 4th February a circular was issued, again drawing attention to screening, isolation, and fumigation, etc. On 8th February, complaints having been received from sister colonies, and foreign consuls having complained of the slowness of notification, a circular was issued to all medical practitioners asking them to report all cases directly to the Board of Health.

On the same day another circular was issued to Commissioners of Health of all parishes, acquainting them that the Board of Health had decided to appoint a central inspector to inspect the island day by day.

The various parishes were also asked to appoint more inspectors. Again this was a useful move, but in the name of common sense, why was not the allessential thing done and a medical officer appointed? The sanitary inspectors are most worthy and excellent 
men, as I well know, but it was unfair to thrust upon them the duties of experienced medical men.

On the 18th March a circular was issued to all medical men, asking them to help me on my arrival in any way they could, and to furnish me with notes of their cases. This was exceedingly generous and wise; but it shows how really headless and armless the Board was. In any other community the Medical Officer would have had all that ready as a matter of course.

Useful rules, taken from the Public Health Act of 1898, for dealing with cases of yellow fever were also issued, as well as the hints upon treatment published by John Guiteras. Handbills were widely distributed, and conspicuous posters were affixed in all prominent places, containing the regulations for the destruction of mosquitos as enacted in the Public Health Act of 1898. These are excellent; all they wanted was an active Medical Officer to see that they were carried out to the letter.

\section{SOURCE OF INFECTION.}

From review of the facts in connection with the epidemic, I concluded that yellow fever was introduced into the colony from without. It now remains to enquire whence it came.

1. Quarantine Precautions.-Unless a town knows it is free from Stegomyia, there should be no relaxation of the strict supervision of all arrivals from yellow fever countries. This is well illustrated by the energetic and searching supervision of all ships arriving from infected ports, which the United States Government 


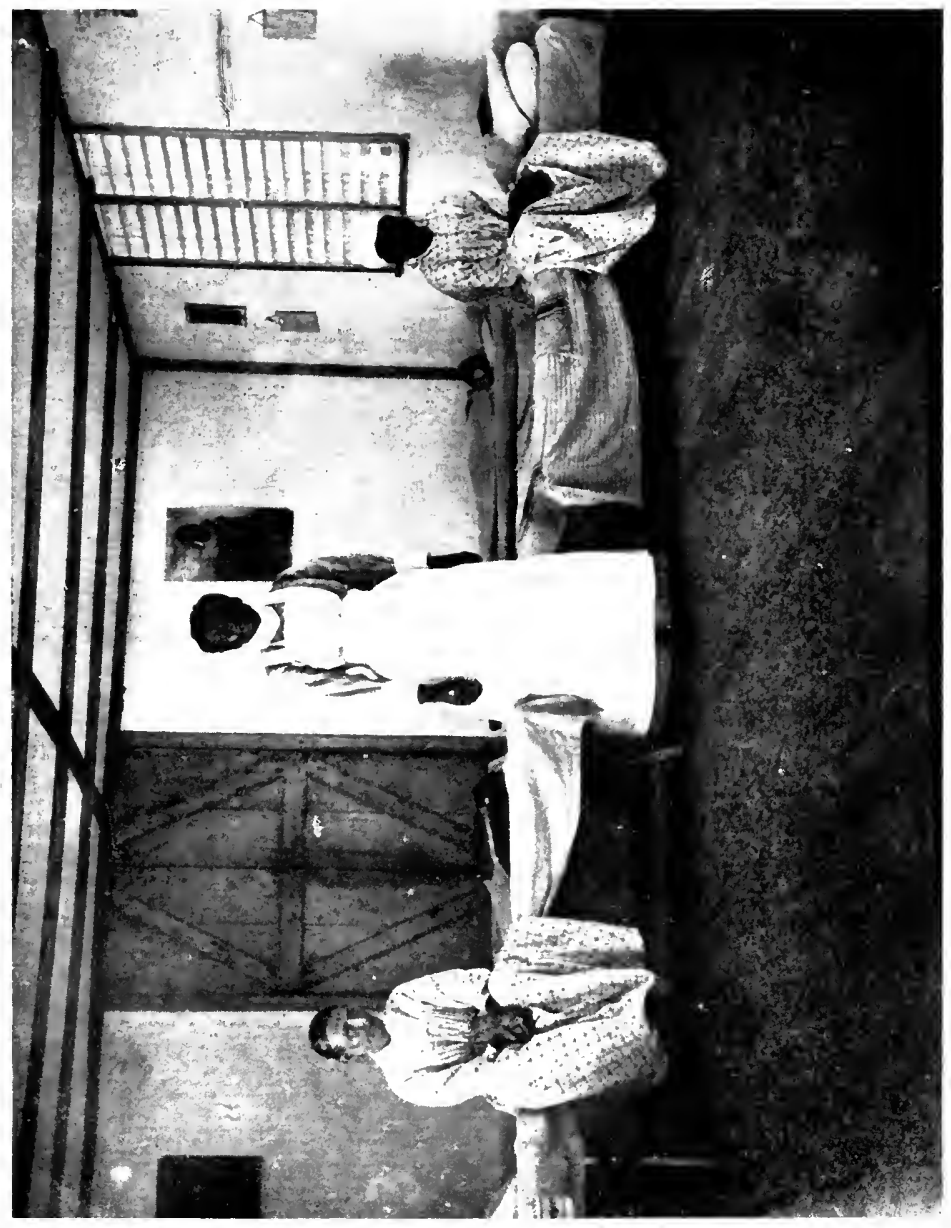



insists upon. I had practical experience of this supervision, when in $1905 \mathrm{I}$ travelled much on the ships of the United Fruit Company. Not only did the American authorities insist upon quarantine and fumigation, but they had medical officers stationed on the look out at all fruit ports in Central America, whilst a medical officer usually travelled on the ships. In 1906, British Honduras followed this example with very marked success. But what do we find in the West Indies? We find that whereas the United States Government insists upon the fumigation of ships before discharging at certain Southern United States ports, where there is a danger of introducing yellow fever - that is, of course, through ships coming from infected countries-we find, extraordinary to relate, that the fumigation has been usually made at Barbados or Castries! thus exposing both these places to a very great risk. No doubt the reason for this curious procedure is that there are inconveniences in the way of fumigation at the infected ports of departure, whilst at Barbados and Castries, where less rigid views prevail than in the United States, ships are allowed to discharge and have intercourse with the shore and to fumigate, provided they have clean bills of health. But it is well known there is a risk of overlooking mild cases. Mild cases would in all probability be diagnosed as malaria or influenza, and would not, therefore, be regarded as at all dangerous or justifying rigid quarantine measures. But we know from experience that these are precisely the cases which introduce infection. There is also, of course, the danger that such ships may carry infected 
Stegomyia, which may either get ashore or more probably infect labourers arriving from the shore who help to discharge the cargo. Therefore it stands to reason, that if the United States, which is much farther away, insist upon fumigation of vessels sailing from infected countries, is it very much more necessary for the West Indies to insist upon similar action before the arrival of these ships in their ports. It is no part of modern quarantine administration to make commercial intercourse difficult; it is designed to protect commerce by lessening the risk of disease, and I would recommend that in the case of all ships arriving from places where we know yellow fever is endemic, that the passengers and crew should be carefully examined by the port medical officer, and that passengers going ashore should be kept under surveillance. Of course, when the towns and villages of the West Indies have banished the Stegomyia, the risk from yellow fever will disappear, and it need not be feared any more that it is in Liverpool, London, or New York to-day. There is another reason why strict quarantine administration is still necessary, and that is on account of plague. This disease is travelling to the West Indies from the Pacific side of the American continent, and with the increased communication with the Esst great care is still necessary, for plague is not so easily dealt with as yellow fever, and much more stringent measures against rats are urgently required. It happens that many of the countries in which yellow fever is endemic are those in which plague has made its appearance.

From evidence placed before me in Barbados by 
Dr Bridger, Port Quarantine Officer, and Dr Hutson, an observant and leading physician in Barbados, there appears to me several possible sources from which infection might have been introduced, either through infected man or through infected Stegomyia, namely :-

1. Martinique.-In 1908 there was a sharp epidemic of yellow fever; there were 99 cases reported and 20 deaths, and the first officially notified case was on 22nd June 1908. Until we have a full official report, it will be impossible to conjecture whether they had had yellow fever before this date or not; they no doubt had (see Appendix).

2. Surinam.-At the end of 1908 there was yellow fever in this Dutch colony, which was attacking new arrivals.

3. Venezuela.-As this is still a yellow fever stronghold, and poorly organised from the sanitary standpoint, it is a possible source of infection.

4. The Amazon.- This is also an endemic focus, and unquestionably it is also a possible infecting source.

5. St Vincent.-Five cases of yellow fever occurred in this colony towards the end of 1908 . The disease was at once taken in hand and did not spread. In my opinion, the disease was introduced into St Vincent, and could not have been endemic. The few cases are of great interest, because they are corroborative evidence that yellow fever infection was in the West Inclian 
zone, and that Barbados and St Vincent were both infected from an outside source. It is not likely that St Vincent infected Barbados, but both might have been infected from a common centre.

6. Trinidud.--In January 1907, yellow fever began to occur and newcomers were attacked; numerous cases were reported up to 1909. As a case was notified in January 1907, it is reasonable to assume that infection was present in Port of Spain in 1906, but was not recognised.

Now Trinidad, as we shall see when discussing that colony, is in close relationship with Venezuela-a yellow fever stronghold-and, as it appears to me evident that yellow fever has been in Trinidad at least since 1906, therefore it is quite possible that Trinidad, having itself become infecterl from Venezuela, was the unconscious means of disseminating the disease to other islands.

In my opinion, the recent outbreak in Barbados, affecting, as it did, largely the black population, is striking testimony to the fact that the recent outbreak was not an endemic conflagration; on the contrary, the disease had been so long absent from the island that there had been time for the growth of a non-immune native population.

In other words, the native had become as 
susceptible to the disease as the rawest arrival from Europe.

In a country where yellow fever is endemic, as for example, places on the Amazon and Orinoco, or as in Barbados itself-many years ago, the opposite was the rule-the natives are immune, and do not suffer in epidemics, because they have had the disease when they were young, and in such a mild form that it was never diagnosed. They had, in other words, an ambulatory form, as happens so frequently in the case of many other diseases. The non-immunity of the natives in the recent outbreak coincides with the evidence that the last cutbreak was in 1881-that is, some twenty-six years before the present one.

With regard to Trinidad, I have shown that yellow fever was present there in all probability in 1906. Dr Hutson has kindly given me his own reasons for supposing Trinidad to be the source. They are as follows :-

"My reasons," he states, "for thinking that yellow fever was introduced into Barbados from Trinidad in 1907 are that-

1. "Yellow fever had been prevailing in Trinidad during many months of 1907 , and after the notification of cases there had ceased, the Health Officer of the port of Barbados, with marked reluctance signified his intention of no longer carrying out the restrictions prescribed by the West Indies Convention of 1905.

2. "The reluctance of the Health Officer was shared by the Board of Health of Barbados, and was the result of continued notices in the press of Trinidad, recording the deaths of newcomer's and persons of short 
residence in the colony after illnesses of a few days' duration.

3. "The Board of Health asked the Governor to apply to the Governor of Trinidad for medical reports of some of these cases, and these reports by no means tended to allay the anxiety felt on the subject. Several of the deaths were reported to have been from 'malignant malaria,' and in other cases the reports disclosed symptoms that suggested the probability of yellow fever.

"It may be added that during the outbreak in Trinidad, it was noticed that a large majority of the cases of yellow fever notified in Port of Spain, Trinidad, were certified by one medical man, and the natural inference was that as he could not possibly be attending the whole community of the Port of Spain, there must be many other cases not notified. The incidence of the cases showed also that practically all the victims were newcomers from northern climates with periods of residence of less than one month and upwards."

As showing the possibility of infection coming from Trinidad, the following memorandum is of interest :-

On 10th August 1907, Surgeon Urquhart of the M.U.S.M.H. service reported to Washington that on 31st July the s.s. Atrato from Trinidad landed a stowaway suffering from yellow fever.

With regard to the Amazon, there is regular communication by a line of steamships proceeding on their way to United States ports, and it is customary because more convenient for them to fumigate either at Barbados or St Lucia. This is done on account of the prevalence of yellow fever at the ports of departure on the Amazon, and because certain United States 
ports (Galveston, for example) insist on fumigation. Apparently Bridgetown and Castries are selected as convenient places at which to carry out the fumigation, for, in all probability, during the disagreeable process of sulphur fumigation, passengers and members of the crew may go ashore and enjoy themselves. Now we have evidence that the members of the crew, and passengers, of these steamers do occasionally contract yellow fever at the ports of departure.

The following statement shows the number of such cases which occurred in a period of eighteen months in the years 1908 and 1909 :-

1. A fireman contracted disease in the month of August, in Manaos; it was of a malignant type, with early black vomit, and the man died on the fourth day.

2. A fireman developed the disease in Iquitos, in the month of December 1908; early albuminuria, no black vomit, died on the sixth day.

3. A steward developed yellow fever in Iquitos, month of April, of a similar type, and recovered.

\section{Month of April.}

4. Steward (death). do. (death). do. (death). do. (recovery).

Engineer (death). Two passengers (recovery).
All contracted the disease alongside of hulk used as a storehouse and station for labourers going to and from new railway

Note.-All ships are supplied with mosquito nets, and all members of the crew must use them. As far as possible, gauze doors are provided for the officer's and engineer's. 
The lighters of the company are periodically cleaned and their bilges injected with kerosene.

After every case, which is at once isolated, the quarters are fumigated twice (with a twelve-day interval).

All the above cases were primary. There have been no secondary cases in any of the ships.

Unless there have been suspected cases of yellow fever on board, fumigation is never done on leaving any infected port. It is therefore not unreasonable to suppose that these ships may carry either infected mild cases of yellow fever or infected Stegomyia; in the former case if such an infected person went ashore he would infect the abundant local supply of Stegomyia; in the latter case if lightermen or labourers went on to the ship they might become infected from infected Stegomyia which might be on board and so convey infection ashore. We find that on 7th December 1906 Consul Clare reported to Washington the landing of a suspected case of yellow fever from the s.s. Maranhense, from Para; the ship left Para, 3rd December 1909, and arrived at Barbados on 7th December 1909; the ship reported no quarantinable disease, the ship's doctor regarding the case as evidently one of malaria; no unusual diagnosis, and not more amiss than the diagnosis of dengue fever in the case of the sailors of the H.M.S. Indefutigable. The Health Officer in charge at Bridgetown had the case quarantined, as he was not satisfied with the diagnosis. But it appears that the other passengers were allowed to land! The distance by time from Para, Manaos, or Iquitos on the Amazon 
to Barbados is not long, occupying from four and a half to nine days from the nearest and farthest ports respectively; so that one of the crew or passengers infected about the time of departure might arrive in Barbados, not at once suggestive of yellow fever, but, nevertheless, in a condition capable of communicating infection on going ashore to the Stegomyia. It is well known that the Stegomyia can easily survive such a short voyage; therefore I consider that ships arriving from the ports on the Amazon should always be most carefully examined, and should be fumigated before contact with the shore is permitted. The ships should preferably be fumigated at the port of departure as a routine measure, so long as ports on the Amazon are not put in proper order and act as endemic foci of yellow fever. The Amazon is to Barbados what Venezuela is to Trinidad, and the same measures of safety should be adopted in both colonies. 


\section{CHAPTER X}

HEALTH PROGRESS AND ADMINISTRATION IN BARBADOS

IN the preceding chapter, and also in Chapter II., I have given an account of the terrible mortality from yellow fever in Barbados which took place annually up to the nineteenth century, when sanitation began to make headway, and when, above all things, drainage and a new wholesome water-supply took the place of the old-time polluted wells. These reforms, as I have said, struck at once the death-blow to cholera and all water-borne infections, and were the factors which took from yellow fever in Barbados its endemic character. From the day when a pipe-borne water-supply was laid on, yellow fever receded.

Immediately upon my arrival in Barbados I organised a house-to-house inspection in Bridgetown, with the view of finding out the distribution and number of the breeding places of the Stegomyia calopus.

Mosquito Survey and General Cleaning-up in Burbados. - This part of my experience in Barbados was the most pleasurable. It enabled me to become acquainted with the poorer classes, and I can now testify to the good sense and good temper, and to the 


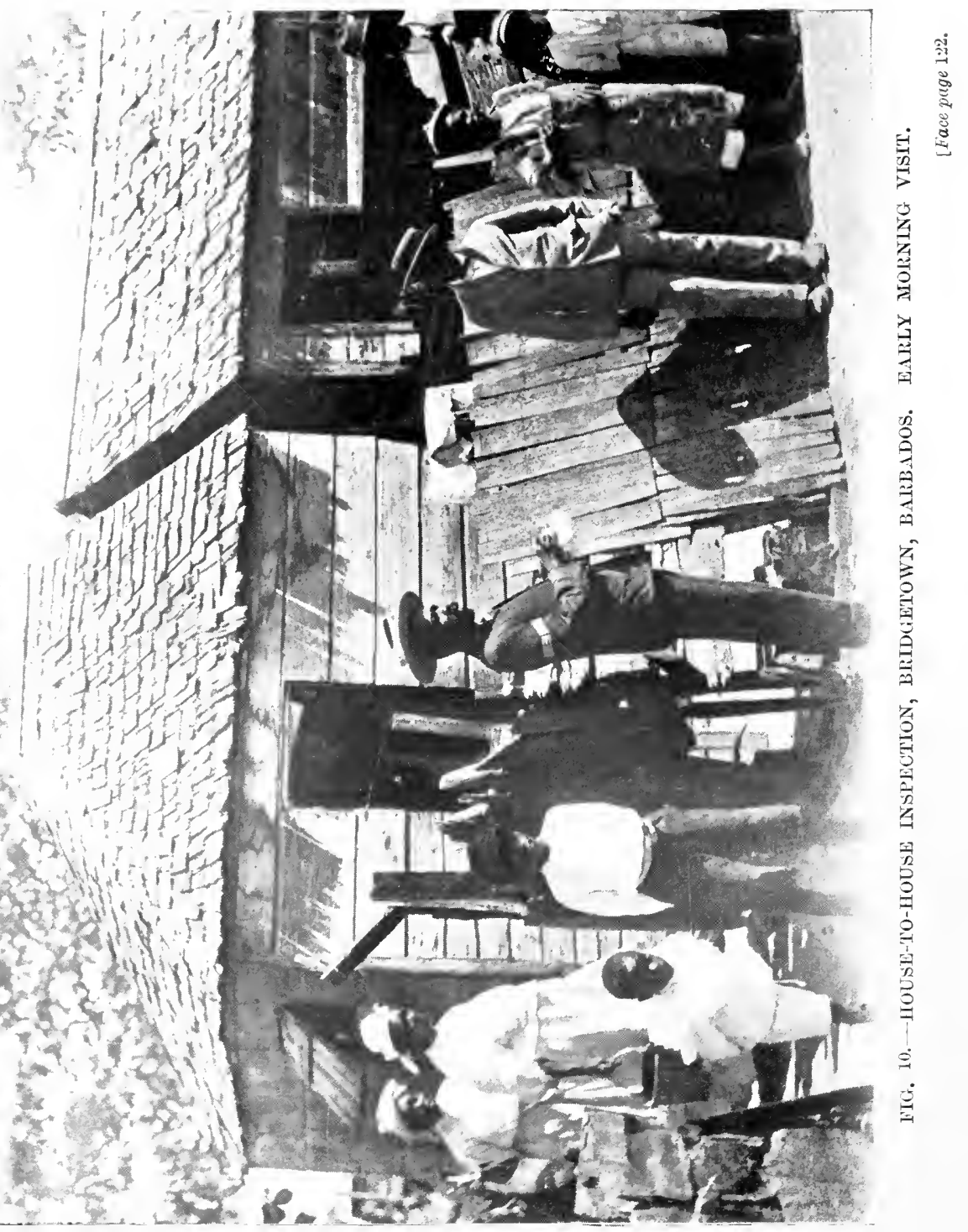



enthusiasm shown by all classes, including the poorest, to assist in the work of cleaning and getting rid of mosquito larvæ. It was, moreover, on these rounds that I learnt to-

Be to their faults a little blind,

But to their virtues very kind.

My aim was to instruct the householders and to get them to come into line of their own free will. Taking all things into consideration, especially the novelty and strangeness to them, of waging war upon that which all their lives they had looked upon as harmless, namely, the wiggle-waggles or worms, as they called the mosquito larvæ, they took in excellent part our upsetting their water-casks and water-receptacles; indeed I have many times seen them overcome by the sense of shame when we found worms in their water. It was as objectionable to them as in England the finding of bugs in a bed would be.

Another pleasing feature on these rounds was that I was accompanied by the Chairman of the Sanitary Commissioners of Bridgetown, St Michael's, my friend the active $\mathrm{Mr}$ Graham Yearwood, my colleague $\mathrm{Dr}$ Hutson, and a goodly array of sanitary inspectors, including Messrs Brewster, Williams, and Cumberbach, with their assistants. They were all untiring in admonishing and reasoning with the people. I remember upon one occasion when an old lady remonstrated with Mr Brewster that worms could not possibly do any harm, the good-tempered inspector silenced the argument by retorting: "Madam, I too once believed as you 
do." Upon another occasion, when I discovered larvæ in a flower vase, the lady of the house was so annoyed at her negligence that she smashed the vase in pieces, with the exclamation that that vase should never offend again. We were also accompanied by the dust contractor with his cart and men, and whilst some of us were engaged reasoning with the attentive and good-tempered crowd, and explaining to them the meaning of our visit, others examined minutely every water container; another group collected all the rubbish, tins, broken pots, etc., and took them out to the cart. There is little doubt that by this method, and it is the plan I adopt wherever I go, I learn more; at the same time, the people also learn and appreciate the attention bestowed upon them. My experience of the state of cleanliness is a favourable one. Altogether, I examined, from 8th March to 25th March, in Bridgetown, 525 yards. In these I found 993 water-holding receptacles, including :-

$\begin{array}{llllr}\text { Barrels } & . & . & . & 177 \\ \text { Tubs } & . & . & . & 224 \\ \text { Jars } & . & . & . & 168 \\ \text { Kerosene tins } & . & . & . & 44 \\ \text { Buckets . } & . & . & . & 278 \\ \text { Odds and ends } & . & . & . & 100 \\ \text { Cans . } & . & . & . & 2\end{array}$

The larvæ of Stegomyia calopus were found upon sixty premises; the larvæ were present, therefore, to the extent of $11 \frac{1}{2}$ per cent. ; this is a comparatively small proportion, and there can be no doubt whatever that this proportion must be infinitely less than formerly. 


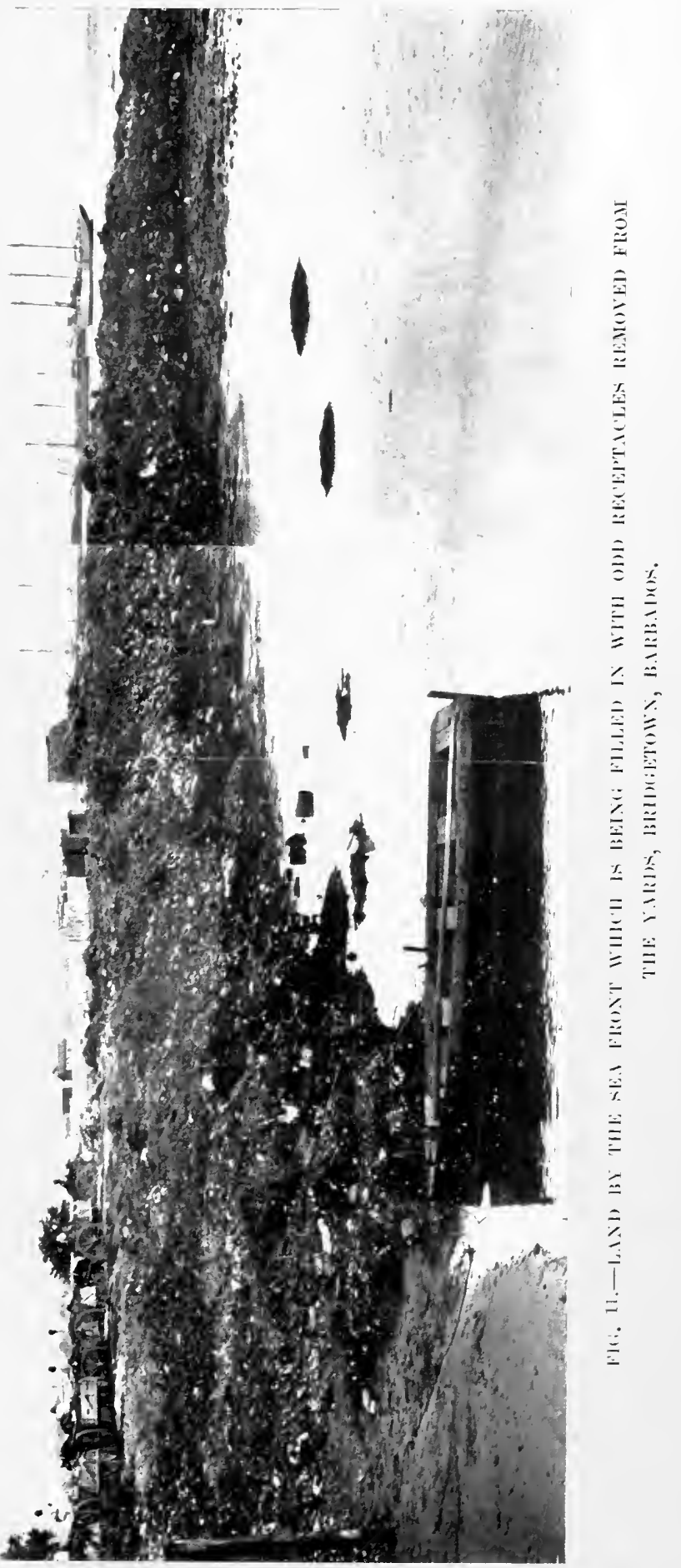



I found the largest number of breeding places in those parts of the town where the cases of yellow fever had been most numerous.

There is no doubt in my mind that the factor which has led to the diminution of the breeding places of the yellow fever mosquito has been the introduction of a pipe-borne water-supply. This did away with the necessity of storing water in barrels, for the water is now either supplied to a tap on the premises, or to a standpipe in the road near by. The contrast in this respect to Belize, where $I$ found, in 1905 , the rain-water stored in innumerable barrels, was very striking. The receptacles which were found most frequently with larvæ, were the wooden water-barrels; and the ultimate destruction of the breeding places of the Stegomyia resolves itself into getting rid of barrels, for now that there are taps, there is really no necessity to store water. Of course, it is difficult to eliminate old customs suddenly, and many cling to their water-barrels. I found that more often than not, the drinking-water barrels were kept in the kitchen-the ideal place, owing to stillness, warmth, and subdued light, for larvæ to develop rapidly, and, moreover, for the adult Stegomyias to find close at hand their victims. The reasons given for keeping the drinking-water in the kitchen, was that it prevented the poisoning of the water by revengeful neighbours, which might happen were the cask left out of doors. In this connection, I also learnt another curious custom. Time and time again I found no larvæ in the water in the barrels, when circumstances indicated that they should be present. Their absence 
was due to the presence of one or more small fish, placed in the barrel, to detect, so I was informed, the presence of poison, should it be added by anyone. The poison would kill the fish, which would float to the surface, whereupon the water would be thrown away. No doubt this custom had led to a reduction in the amount of larvæ. Recently, however, the factor which has above all others brought down the number of breeding places on premises in Bridgetown and in other districts, has been the vigorous inspection of all yards. Great credit is due to the able body of sanitary inspectors, backed up by the infliction of judicious fines. Since my departure, I have been informed (18th July 1909) that a recent examination of premises in various parishes has shown that only 0.45 per cent. of the houses inspected were found to be harbouring larvæ; this is, as my informant adds, a very remarkable result, which does credit to the vigilance of the inspectors. It shows what can be done. The percentage which I found in March was approximately $11 \frac{1}{2}$ per cent. Surely a colony which can bring about this reform is quite capable of making its island a veritable sanatorium and a model to others!

Infiction of Fines.-The inhabitants having been taught by the inspectors the danger of harbouring larvæ and cautioned that it was an offence to do so, the next step was the bringing obstinate offenders before the magistrates and inflicting fines. This has been done, and altogether some 99 convictions were obtained from March to 15th May 1909 (see Appendix). This also is a very healthy sign, and argues well for the future security 


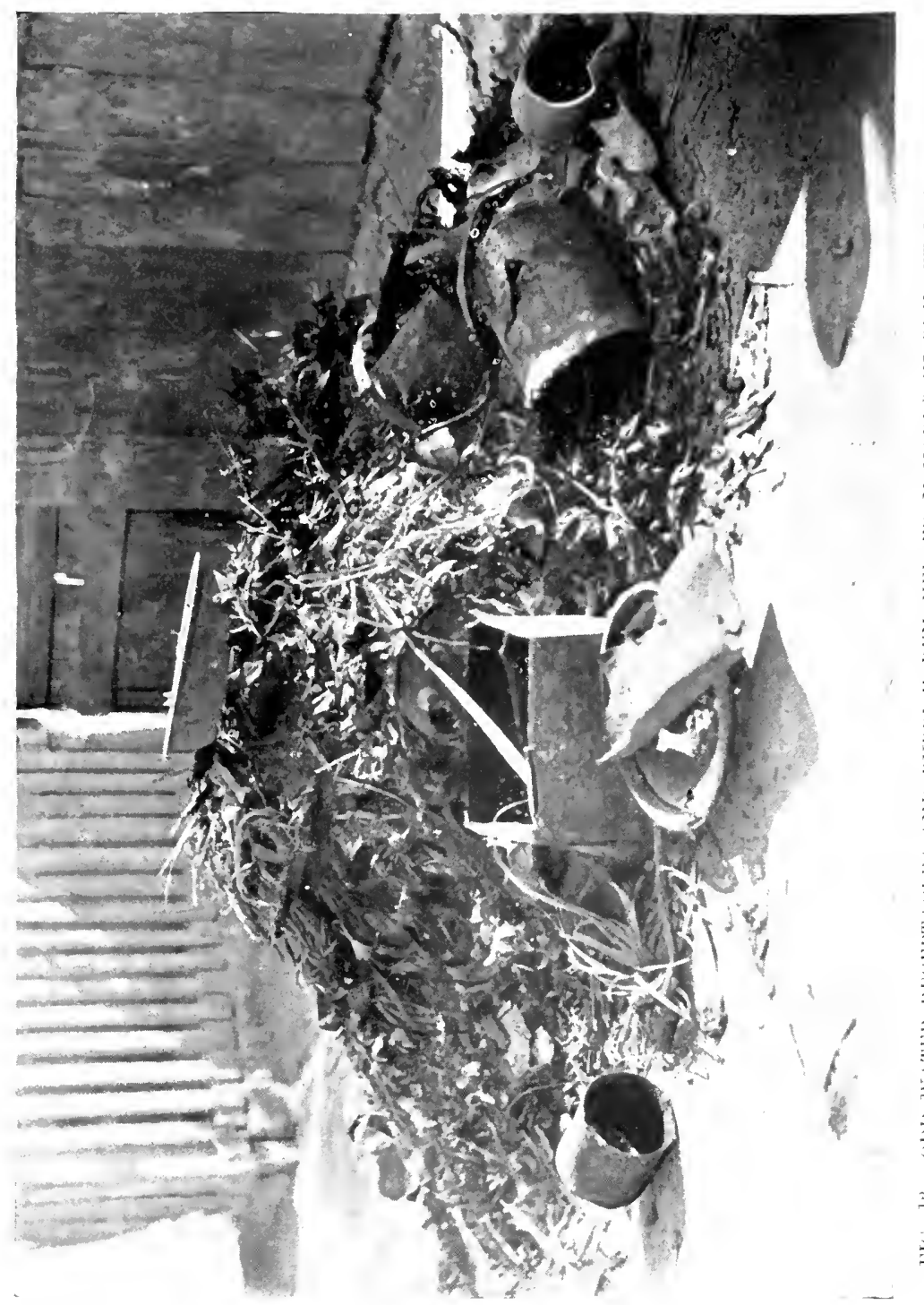



of Barbados - that is, if this enthusiasm will last in the absence of modern organised health machinery.

Health and Medical Administration.-The sanitary organisation of Barbados is in very many ways antique : as ancient and as picturesque as the characteristic sugarcane-crushing windmills dotted all over the islandeminently respectable, but shabby and not in conformity with the present age nor calculated to yield the maximum return.

In the absence of any precise printed information, Mr Graham Yearwood had kindly furnished me with the following useful digest of the mediæval sanitary administrative system in operation in the colony, dating from 1645 .

\section{Parishes ANd their Government.}

Control: Central or otherwise.-The island of Barbados was divided into eleven parishes or districts in the year 1645, by Mr Philip Bell, the Lieutenant-Governor of this island at that period, and from then till the present time has remained so divided, St Michael's being the Metropolitan parish. Each of these parishes is governed by a Vestry or Parish Council elected by the ratepayers of the same, and is quite independent of any central or Government control, the number of vestrymen being not less than ten or more than sixteen in some parishes, and not less than six or more than ten for others.

Commissioners or Boards appointed by Vestries.The Vestries then annually from their body appoint Commissioners of Highways, who have charge of and control of those Highways; Sanitary Commissioners, who are vested with the duty of maintaining and looking after the sanitation of the parishes, etc.; Poor Law 
Guardians, who have charge of and maintain the poor of the parishes. All these bodies, once appointed, are emancipated from any control of the Vestry during the year of office, and can only be called to account by the ratepayers on their offering themselves for re-election.

Powers and Duties of Boards.-These boards appoint their own officials, such as Inspectors of Highways, Sanitary Inspectors, Medical Officers, independently of the Vestries. The sanitary boards, about which this paper is principally concerned, consist in all parishes other than St Michael's of three members, and in the case of St Michael's of nine members, five of whom must be vestrymen, while the other four are nominated and appointed by the Vestry and are not bound to be possessors of any legal qualification for that office.

Sanitary Commissioners to make Returns: Vestries bound to Furnish Means.--These sanitary boards are required by the law to make a return to the Vestries of the sums of money which shall appear to them to be required for ordinary sanitary purposes for the ensuing year, and in cases of sudden emergency, such as the unexpected appearance of dangerous epidemics requiring further sums, they have power to make a special return thereof to the Vestries, which body is required to raise and place in the hands of their parochial treasurer all such sums as may be called for by the commissioners, such sums to be raised and collected from the ratepayer's.

Duties of Commissioners.-The duties of the commissioners are defined in the Public Health Act, 1898-9, and may be summarised as follows:-

1. To appoint inspectors, of which there are two in St Michael's, the parish being divided into two districts, with six sub-inspectors in each district, 
but at present there are eighteen in each district ;

2. To make bye-laws;

3. To ensure cleanliness ;

4. To remove nuisances ;

5. To inspect houses; and

6. Generally to maintain sanitation, etc., to the highest point of excellence.

Open Drainage System adopted.-Armed with these powers, the commissioners have from time to time built up a system of open concrete drains, to which are connected open gutters, short tunnels, short pipes, and partly covered drains. In such cases where the drains are under the streets, they are ventilated at intervals by iron grates so constructed that they are easily opened for removing any obstruction, and through which a hose attached to the fire hydrants can be placed and the drains effectively flushed by water under a strong pressure, thus driving everything before it into the outflow into the sea or tidal river.

Labourers appointed to Flush and Clean Drains.-A staff of labourers is employed with suitable implements for sweeping and cleaning daily all the city drains, which are used only for the purpose of receiving the washing of the streets, water from houses, and stormwaters.

Sewers.-There are no covered sewers in Bridgetown such as are to be found in cities in other places, the system being one of open drains.

Nature of Sewage.-No night-soil or other freal matter is permitted to be thrown into the drains, gutters, etc., and the law has provided ample means for punishing all offenders when caught-no easy matter, however.

System adoptod for removing Night-soil.-There 
are two systems in use for the reception of night. soil :-

1. The old pit.

2. The bucket, or supposed dry-earth system.

In the first case, these pits are cleaned out when necessary, and their contents either thrown into the sea, or taken out of the town and suburbs and buried in the earth for manurial purposes.

In the second case, they are emptied nightly into the sea from places provided by the commissioners at places convenient on the sea-shore; a ladder or steps is provided down to the sea, so that after being emptied the vessels can be washed out with sea-water.

Disposal of Sewage from Water-closets.-The disposal of sewage from water-closets is provided for by the following regulations :-

1. All existing water-closets, and all water-closets hereafter to be erected in the city or suburbs of Bridgetown, shall be provided with separate pits closed with masonry and unconnected with any other pit whatever.

2. No urine or other fluid from anywhere except the flush from the water-closet shall be allowed to enter any water-closet pit, which pit shall be provided with an iron ventilating pipe of not less than 1 inch in diameter, reaching not less than 3 feet above the eaves of surrounding buildings.

Disposal of Rubbish.--The Bye-law No. 2 provides that the occupiers of all houses, etc., shall daily have swept the yards and enclosures thereof, the streets, pavements, and gutters in front of and around the same, as far as the centre of the streets, some time before the hour of 8 A.M.

Cleaning of Yards and Streets.-This matter is then 


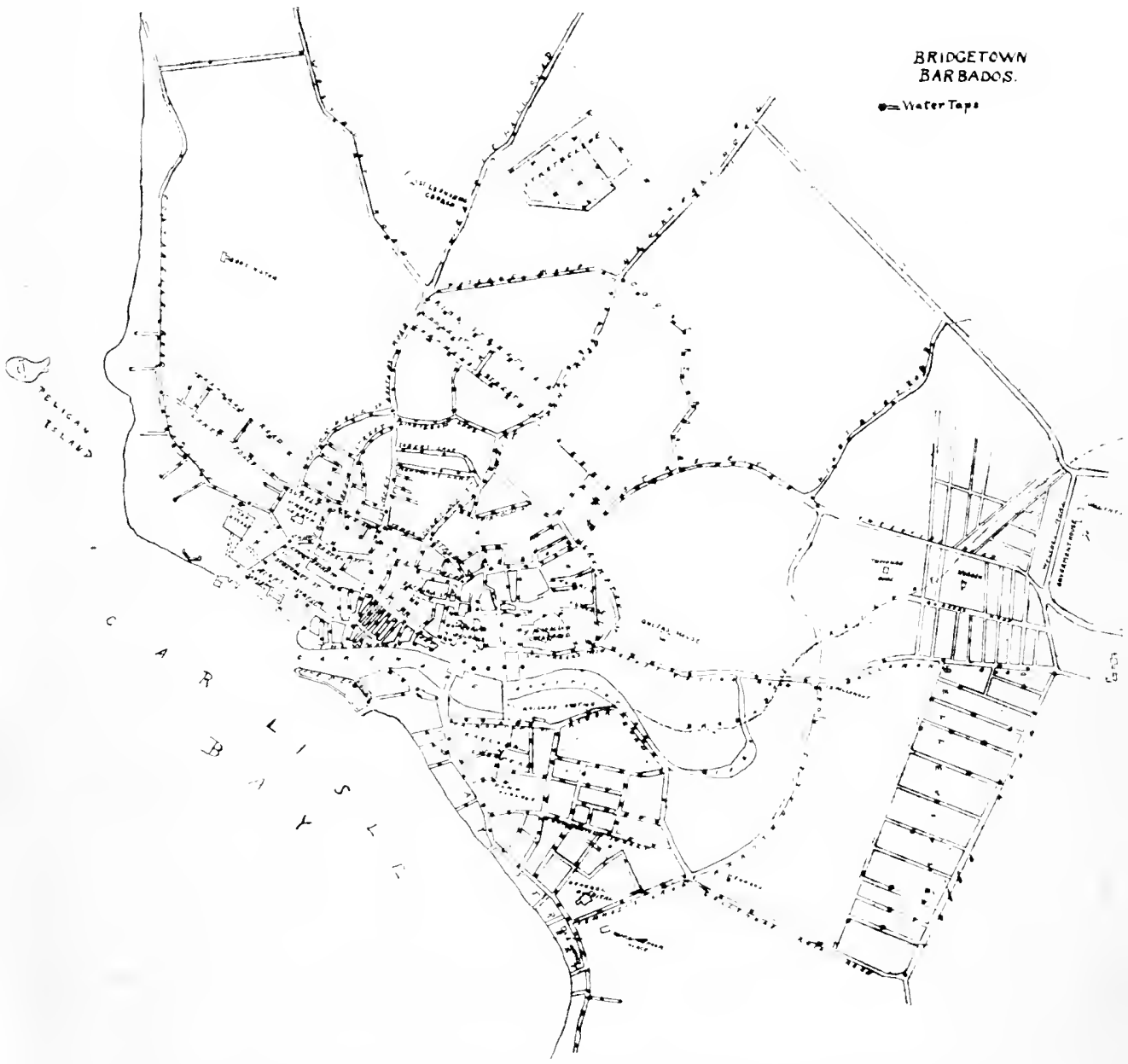

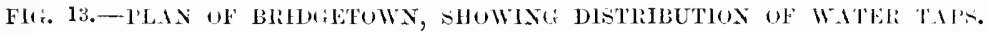



removed by the scavengers' carts supplied by the commissioners, which go round the town and remove the same to such place or places as the commissioners require it to be placed. At the present time the place known as the Reef is being rapidly filled up and reclaimed from the sea by this refuse, and the place known as the Constitution River and Bay Street improvement grounds are being similarly dealt with, no dead animal, or fæcal matter, however, being allowed to be thrown on to these places.

Droppings of Animals. - The droppings of animals on to the streets are eagerly removed by small boys and old men, who dispose of them for manuring gardens and nursery grounds.

These are the present simple methods which have been adopted by the sanitary commissioners, and have so far been found to be most satisfactory. They may not be the most up-to-date ideas, but in a tropical climate they have worked well.

With regard to the open drainage system in vogue in Bridgetown : it works well, and by constant flushing the drains are kept clean; but a few bad ones exist, some running underneath houses.

With regard to the cess-pit system, it is believed that owing to the exceedingly porous nature of the coral limestone, the night-soil soon disappears; this may be, but it seems to me that it is unwise in any case to pollute the subsoil water, especially as the island obtains now a splendid supply of drinking-water derived from the subsoil. The coral limestone, like all these formations, is full of large fissures, and every possible care should be taken to keep this essential and magnificent water-supply absolutely above suspicion. This can only be done by doing away with the sunken pits. 
In view of the threatened spread of plague towards the West Indies, it would be advisable to have more space underneath the houses. At present very many of them are too close to the ground, and the tendency is to throw odds and ends, rags, and rubbish generally, underneath. Owing to the smallness of the space, the rubbish cannot be easily got out. I had an opportunity of seeing one of these houses taken down and the accumulation of several years' rubbish revealed. This rubbish is the ideal nesting place of plague, rats and fleas, and constitutes, to my mind, the greatest danger at the present time in Bridgetown. It is a very real danger, and should be rectified without delay. The houses should be raised so as to let the sun and air and the eyes of the sanitary inspector have full play: these are the deadly enemies of rats and fleas. The broad comment upon the existing sanitary system is that as far as it goes it is excellent, and has done good work in the past and in times of peace - that is, when no sudden emergency has cropped up. In this respect, it is again like other "good old" systems all the world over.

A medical gentleman of very considerable experience in Barbados has very kindly furnished me with a digest of the weakness of the sanitary and medical administration, and as I personally endorse the views expressed therein, I reproduce them here :-

The general board of health have plenary powers to pass order's, rules, and regulations to meet any emergency, such as the approach of a serious epidemic, or to stimulate the activity of the boards of sanitary cornmissioners during periods when special preventive 
measures are necessary. The board also pass bye-laws and special regulations submitted to them by the respective boards of sanitary commissioners, if approved.

There are, however, no regular health reports submitted to the board of health, and no information as to the health conditions of the island is forthcoming unless specially asked for. Consequently the board of health are not aware whether at any given period the sanitary conditions are such as may be reasonably expected to stand the strain of the sudden introduction of infectious diseases. From this it follows that neither the Executive, the board of health, nor the general public can feel that the sanitary organisation is such as to make it impossible for these diseases to gain a footing. There is, in consequence, general uneasiness, amounting often to actual panic, on the near approach of any dangerous epidemic, and in the presence of an outbreak of yellow fever or smallpox an extempore organisation is hastily made to enable the sanitary authorities to meet the emergency.

Neither the Executive nor the board of health have a medical officer to keep them informed of the health conditions of the island, to give a responsible opinion about the nature of an infectious disease which may make its appearance, to suggest preventive measures for controlling these special diseases or the ordinary diseases which prevail under insanitary conditions in any community. For example, if any local outbreak of typhoid fever occurs, no special attention is directed to its causes unless it assumes alarming proportions, and there is no regular inspection of the sanitary work of the island to ascertain any defects which exist, or to make responsible suggestions for its improvement.

Again, the boards of sanitary commissioners in the respective parishes have no sanitary medical officer to advise them in health matter's or to carry out effectively 
the measures necessary to control a serious outbreak of epidemic disease.

In most parishes the parochial medical officer, appointed under the Poor Relief Act to attend the poor of the parish, has a seat at the sanitary board and is the adviser of the board on health matters, but his only responsible duty is to make a quarterly report on the sanitary condition of his parish. There is no definite inspection or enquiry into health matters required of him, and the reports are often perfunctory.

As the appointment of the parochial medical officer is in the hands of the local Vestry, which can at any time relieve him of his appointment at six months' notice, he is not in a position to comment fearlessly on insanitary conditions, which may offend the susceptibilities of vestrymen, on whose goodwill his tenure of office depends; and, human nature being what it is, he is apt, unless he is a man of more than ordinary courage and fearlessness, to see things as his employers see then.

In order to raise the standard of sanitary organisation in the island and to make it what the conditions of the West Indies Sanitary Convention imply that it should be, the following improvements are necessary :-

1. A permanent infectious hospital in each parish for the treatment of the four quarantinable diseases, smallpox, yellow fever, plague, and cholera, which may be used in the absence of these diseases for the treatment of typhoid fever and other ordinary infectious diseases.

2. The appointment of the parochial medical officer in each parish as medical officer of health for the district. He would be the responsible adviser of the sanitary board, and his duties would consist in sanitary inspection duty and the furnishing of reports on the sanitary condition of the district, according to a fixed 
scheme, as obtains in England. $\mathrm{He}$ would also examine persons under surveillance according to the provisions of the Quarantine Act, when the health officer cannot inspect them owing to the distance of their homes from Bridgetown, or, in the case of persons residing in Bridgetown or St Michael's, when the numbers under surveillance are greater than the health officer of the port can deal with. He would also perform extra duties in the case of an epidemic, such as the examination of all persons reported by the sanitary inspectors as ill at their homes, the treatment of persons in the infectious hospital, the examination of contacts, and the regular inspection of the infected areas, to discover any conditions which promote the spread of the epidemic. The duties described in the last two sentences are now paid for by extra fees, often amounting to considerable sums.

These officers should be appointed by the Vestries, subject to the approval of the Governor in executive committee, and half, at least, of their salaries should be paid from the general revenue.

3. The appointment of an island medical officer of health, who would be the responsible adviser of the Government and the board of health in sanitary matters, who would make regular sanitary inspections throughout the island, and furnish reports of the health and sanitary conditions existing, who would be available for advice and assistance to the boards of sanitary commissioners and the parochial medical officers of health, and be responsible for consultation on any doubtful diseases that arise. His duties would, in short, be like those of a county medical officer of health in England.

He should be appointed and paid by the Government from general revenue, and would be at the disposal of Government and the board of health, as the health officer of the port is. 
Sickness and Mortality Returns.-The weakness of the present situation is glaringly revealed when it is understood that there is no registration of the causes of death. In practice, the death of every person who dies without having been seen by a registered medical practitioner, is notified by the police to the coroner, and, except in cases where the cause of death is patent, an inquest into the cause of death is made. From this it is easy to understand how very readily an epidemic may get a start before being discovered. I have pointed out before that it would be a commercial advantage to the colony to have a proper registration as to the cause of death. The island is not unhealthy, and official regular reports of mortality and sickness rates is the only method whereby the outside world can be made aware of the health of the colony. Barbados has nothing to hide and nothing to lose by the publication of these reports; on the contrary, everything to gain. Besides, it is the practice of civilised nations; for by its means any undue mortality is at once revealed and the sanitary machinery set in motion.

The present state of affairs is barbaric and primitive, and the sooner it is rectified the better will it be for the reputation of the island, which must suffer as long as it exists; for it must be taken as a sample of the childishness and stupidity of the people, and therefore must react prejudicially upon business. If large commercial centres are examined in Europe and in the United States, it will be found that in these places the sanitary organisation is brought to the highest degree of perfection, so that the representatives of all nations and 
of every side of commerce and industry may see what is done to protect health. I therefore sincerely trust that the Government will not lose time in bringing in a bill for the registration of deaths and the causes of mortality, and for the establishment of an island medical officer of health and the appointment of. medical officers of health in each parish, to act as medical officers of health for each district. These are not difficult nor costly reforms, and they would lift Barbados into the first rank.

In addition to the antilarval measures which had been started when I arrived in the colony, I also found that measures had been taken to fumigate houses in which yellow fever had occurred, and also that provision had been made for the isolation of cases of yellow fever.

Isolation Hospitals. - A circular was issued on 7th May 1907, to commissioners and inspectors of health of all parishes by the general board of health, drawing their attention to the importance of providing suitable isolation for all cases of yellow fever. During my visit, I made it my business to visit all the parishes in the island and ascertain what provision had been made. I found that with commendable promptness provision of some sort or another had been made. In some instances a wing or a room in the almshouse had been effectively screened, or in other cases a small house had been rented and thoroughly screened with mosquito netting. All this had been carried out with very small expense (see Appendix), and the result was excellent. I found that the patients preferred to enter 
these emergency hospitals rather than remain at home. For the prompt manner in which these emergency hospitals were got under way, great credit is due to the parochial medical officers, and the example of their worth constitutes a very strong reason in my mind for advising the Government to promote them into district medical officers of health, and so to make them into medical officers for their parishes. They are fully qualified for this office, and the Government is fortunate in having such a body of men ready at hand. It now remains to make official use of them, for, as things are, they have no official executive power.

Fumigation.-Fumigation of houses in which yellow fever occurred was carried out, but there is every reason to believe that in very many instances the fumigation was not effective. The inspectors have most kindly furnished me with notes from their diaries, and from these it is evident that fumigation was far from complete. The chief fault was that the house was not made mosquitotight before the fumigation started, and in consequence, no doubt, a very considerable number of infected mosquitos escaped into adjoining houses; this is assuredly the reason why the fever continued to spread.

I am aware there are difficulties in sealing efficiently a thrash hut or even a shingle-covered house. But it is by no means insurmountable. The extraordinary success of the anti-yellow fever work in Cuba, where the fever time and time again has been stamped out almost as soon as it was discovered, has been due to the complete fumigation of these huts in the poorer country districts. Now, what can be done in Cuba under even 
more trying circumstances than in Barbados, can be equally well performed in Barbados. What is required is a conscientious and ingenious sanitary officer, either himself to carry out the work or see that it is properly done. It must always be borne in mind, that if a small aperture is left unclosed, the infected Stegomyias will escape through that aperture, and an escaped infected Stegomyia, in its power for doing harm, can best be compared to a mad dog roving through the town; indeed, in its effects in holding up trade, the Stegomyia produces more disastrous results than does the rabid dog.

Quarantine Administration.-Useful and intelligent as have been the inter-colonial West Indian quarantine measures, the impression which I have formed of them is, that they are largely founded on mutual mistrust and suspicion. In Barbados, yellow fever found its way into the island, and slowly spread and lingered on. From whence it may have come, whether from Trinidad, Martinique, or the Amazon, it is difficult now to say. For unless a searching enquiry is started at once, the chance of getting on the right track is lost, and room is only left for speculation, which in nine cases out of ten is misleading and erroneous.

Once Barbados was infected, it became a source of intense anxiety to neighbouring colonies, as an analysis of the numerous official complaints of other West Indian colonies is ample proof. I will, however, in this place, again point out that if the want of a medical head is glaringly apparent in the internal sanitary administration of the colony of Barbados, the 
want of such a head when dealing with questions of external sanitary administration and policy is still more prominently emphasised. In this relationship, the want of an experienced medical adviser, who shall be in immediate touch with the health conditions and health machinery of the whole colony, and likewise with the conditions obtaining in the sister colonies, becomes painfully manifest at every point. Barbados possesses a quarantine medical officer-a gentleman well qualified to inspect the ships. Such an officer is undoubtedly of great service for carrying out that special section of sanitary administration which deals with the careful supervision of all ships entering the port. But at the head of the sanitary organisation there should be a man who, by his training and local knowledge, is in touch with every square foot of the colony, and who, furthermore, is in intimate relationship with his professional brethren throughout the island. Large ports in England and Scotland have, as a matter of course, a chief medical officer of health, who keeps himself daily informed of all sickness in his city and district and port. He knows exactly what cases there are of smallpox, scarlet fever, etc. His quarantine officers board every ship which arrives, and report to him. The medical officer of health is the supreme authority, who will decide upon what action will be taken, and not the quarantine officer. The medical officer of health is naturally in a better position to do so than the quarantine officer, whose whole time should be devoted to examining arrivals. At the present time the quarantine officer in Barbados reports to a quarantine board, largely 
composed of laymen; but as it does not possess a chief medical officer, I maintain that with the best intentions possible, it cannot be in a position to give the best decision. A decision in matters of quarantine requires the opinion of an experienced medical officer of the standard of those to be found in European and American trading ports. Laymen cannot give, or be expected to give, such an opinion any more than the medical officer would presume to advise on matters of trade or shipping. Therefore from this aspect alone the position of Barbados is an exceedingly weak one, and untenable. I will give some illustrations which arose in 1907 :-

Difficulty of Early Diagnosis. - The quarantine officer reported, August 1907, to the quarantine board a case about which he was not absolutely certain was yellow fever or not, and which consequently was not reported as such. Shortly afterwards the case developed typical black vomit and died, and there could be no longer doubt that it was a case of yellow fever. Now, it is precisely in connection with a case like this that the opinion of an experienced medical officer is required. Similar situations of doubt have over and over again occurred in ports like Liverpool and elsewhere, over cases, say, of smallpox. In these cases of doubt, invariably the opinion of the medical officer of health is taken, and if he finds necessary, other experienced men are called in. The uncertainty of the quarantine officer in this particular case might have meant disaster to St Lucia. It is precisely to meet cases of this kind that a senior official is absolutely necessary, on the principle that two heads are better than one in matters 
of so delicate a nature as diagnosis. I can speak from my own experience in the city of Liverpool, and others will agree, upon the imperative necessity of taking counsel with other authorities in matters which are admittedly difficult for one man to decide. The late Administrator of St Lucia, Mr P. C. Cork, a gentleman having very considerable knowledge of all that was most recent in yellow fever prophylaxis, and of much practical experience, wrote to the Government of Barbados, pointing out the importance to his colony of immediate notification of cases of yellow fever, in view of the fact of the constant and easy communication between the two islands, the voyage only occupying a few hours. The Administrator then proceeded to point out that in many instances several days had elapsed after the patients were either isolated or had died before the official notification was received. The explanations of this delay, as given by the administration of Barbados, was to the effect that unfortunately the doctors in attendance upon the cases in question had not been able to agree upon the diagnosis until after some days' observation, or the man's death; which means that St Lucia, or any other adjacent colony, not being on their guard, might have easily let yellow fever in, all because of the indecision of certain medical practitioners. But it is precisely in order to have an assessor or adjuster that the post of medical officer is created. It so happened that in Barbados there was an experienced medical consultant who had no doubt as to what the disease in question was, but owing to the faulty medical organisation he could not, apparently, be officially consulted. 


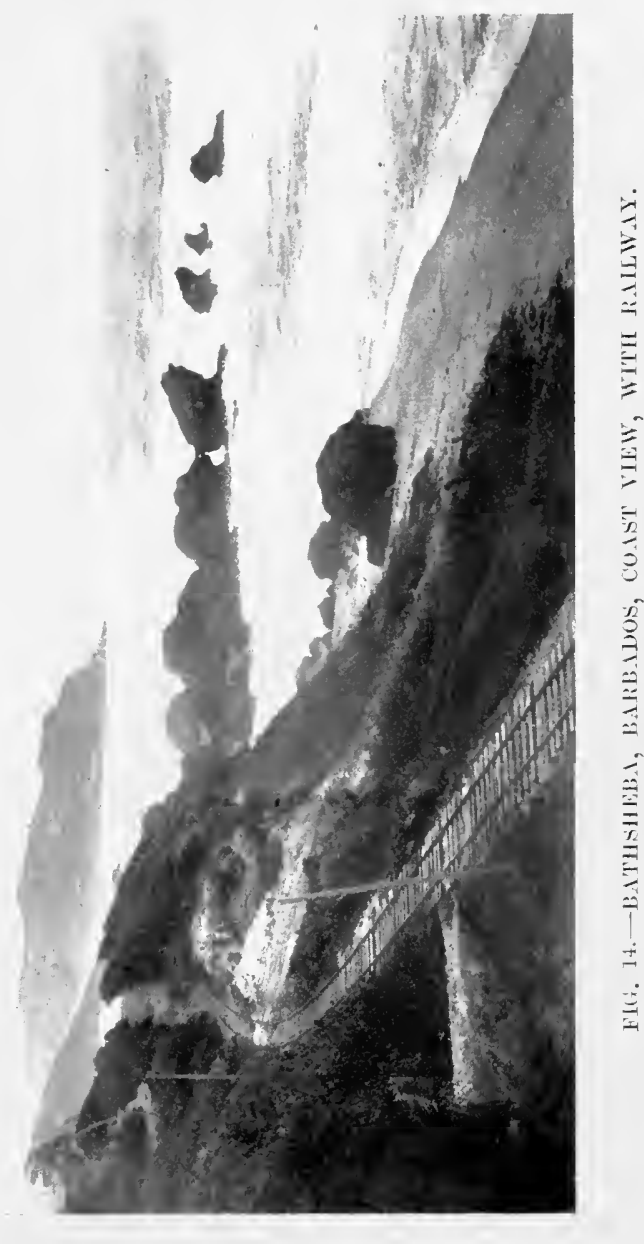

i

क्ष

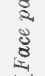



Now, all this breeds mistrust, the inter-colonial mistrust which is to-day so painfully evident. On the other hand, the essence of good business in any walk of life is to inspire confidence. Confidence in the Law has been inspired by the establishment of solicitors and attorneygenerals and judges of all kinds; and so in medicine and sanitation, confidence can only be given by appointing experienced medical experts. This is the practice of civilised communities, and it is but common sense.

Diseases in Barbados.-If the stranger and wellwisher of Barbados wishes to know what are the diseases of Barbados, and to see how healthy it is before he takes his business there or settles with his family, he is unable to get any annual report of the sickness rate, or in fact anything recent which will guide him in forming an opinion; there is no medical head, no authority whose duty it is to regularly furnish this particular and very necessary information. If the student requires similar information, he has to get it as best he can from the medical men of the colony.

There appears to be no endemic malaria. Forms of filariasis are present, and also the disease known as pellagra or psilosis pigmentosa. Reports have been written upon this disease by $\mathrm{Dr} \mathrm{T}$. Sinclair Browne and by Dr Manning, the Superintendent of the Asylum.

Climate and Natural Adrantages of Barbados.-In my experience, Barbados is second to no other part of the world in possessing natural advantages. It has a beautiful climate; the island resembles a large pontoon anchored in the South Atlantic, and is in consequence 
continually swept by the most refreshing breezes. The general appearance of the island is beautiful beyond comparison, recalling the appearance of the mother country in May and June. There is no dense tropical bush; grass-land, sugar-cane, and cotton meet the eye everywhere. The soil, for a tropical country, from the point of view of health, is an ideal one-coral limestone rock, pearly white and as absorbent as a sponge, so that no water rests upon it; water soaks through at once. The climate is therefore dry, and, together with the Atlantic breezes, made delightfully refreshing. I had the advantage of motoring through every parish in the island with my companion, Dr Hutson, and I can certainly say that the beauty of the white coral roads winding through the lovely green meadows and canefields, relieved at every point by sugar windmills and clumps of cabbage palms, is a picture never to be forgotten, and in my opinion, Barbados ought to become the ideal recuperating ground of the tired-out and sick ones of Europe and the United States. I shall never forget the feeling of absolute repose coupled with the stimulating and invigorating effect of the climate and scenery which I experienced at all hours of the day, whether in the early morning, in the noonday sun, when the dazzling roads glared out, or in the late eventide; no matter what the hour, everything in life appeared sweet. Yes, Kingsley said it was "At Last," and I re-echoed "At Last," "At Last." And as if to show how pleased nature was with its handiwork, it refrained from planting malaria. There is no malaria indigenous to Barbados. It is one of those parts of the tropical 


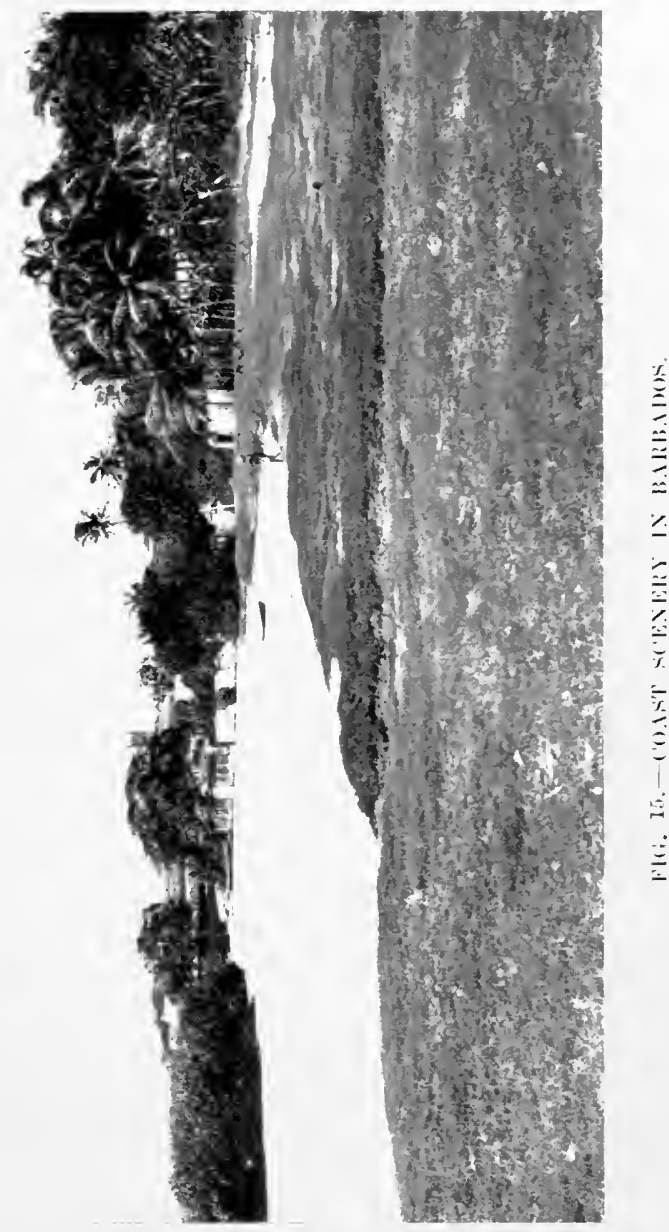

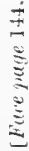

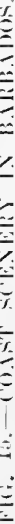



world which stands out unique in this respect. The old medical chroniclers have drawn attention to this fact: that whereas man had in the past introduced yellow fever until it became endemic, malaria, on the contrary, appears never to have been endemic. We now know that the malaria-carrying mosquitos-the Anophelines-appear to be absent from Barbados ; most probably this is due to the fact that the suitable conditions for their development do not exist. Owing to the nature of the soil, the storm-water is rapidly carried off through the innumerable "sucks," which are everywhere to be found in the porous coral rock, and what permanent ponds do exist seem to be perpetually stocked with minute fish-the "millions"-which effectively get rid of any mosquito larvæ. Nor is there any bush on the branches of which epiphytes might find a foothold and water accumulate, and so afford breeding places. No, the only homes the mosquito can find are furnished to a very large extent by man in the shape of barrels, cisterns, odds and ends, and drains. Remove these and cleanse the drains, and the mosquito must perish in Barbados. Therefore, as the line of action has been so clearly outlined by Providence, there can be. little doubt that Barbados will follow up and render the island mosquito-fiee, and the envy and admiration of the rest of the tropical world. It is, indeed, a reputation worth winning, and will cost very little. By the foreshore the innumerable crabs make a vast quantity of water-holding holes, which in turn give rise to a large volume of mosquitos, but fortunately neither Anophelines nor Stegomyia. 
"Barbados leg" and other forms of filariasis, such as "fever and ague," "rose," etc., do exist, and are no doubt dependent upon the supply of culex, which is still abundant; but culex will be swept away, and with it the diseases.

It is worthy of note that the natives of Barbados are exceedingly liable to malaria of a very severe type -that is, when they expose themselves to infection in other countries. In this respect, they are as susceptible as any newly arrived European. This is in favour of the contention that there is no indigenous malaria in Barbados. I have already mentioned that during the recent outbreak of yellow fever the natives suffered even more than the whites, showing also that owing to improved water-supply the annual recurrences of yellow fever had disappeared from the island, and with the periodic cessation of the fever the previous natural immunity of the natives likewise went.

Another disease which attracts attention is pellagra or psilosis, and about which we know very little.

Leprosy.-I visited the Lazaretto, where some 121 cases of leprosy are looked after. I also visited the General Hospital, where there are very many interesting cases. In comparison with similar institutions in Trinidad and British Guiana, one appreciates at once that whereas in the last-named places one observes at all points the organising hand of a medical head, and that some scientific use is made of the immense field for investigation which these institutions offer; by this means helping along the study of tropical diseases to the advancement of medicine and the alleviation of 
suffering. In Barbados, on the other hand, it is exceedingly disappointing to meet with very little scientific interest, and no building-up of a pathological or bacteriological department. In these respects there is a marked contrast with what exists in Demerara and Trinidad, where useful researches are being continually made, and where, moreover, exceedingly good work has already been done and published. I am convinced, moreover, that the hospital authorities in Barbados will find it difficult to attract enthusiastic young men unless they are prepared to recast their system. Nor do I think that they are, under present arrangements, in a position to reap the full benefits of the appointment of a pathologist or bacteriologist : although, of course, it is most desirable that such an appointment should ultimately be made-but not until a chief medical officer of health is created.

Government Entomologist.- In $\mathrm{Mr}$ Ballou, of the Imperial Department of Agriculture, the colony possesses an excellent entomologist, and it is to be hoped that with improved organisation the services of this gentleman will be utilised by the medical as well as the agricultural department, as in the case of the other islands.

On 30th March I took leave of Barbados, after having spent four weeks in the island, during which time I got to know and to love its inhabitants. The freshness and sprightliness of the island has had its effect upon all classes. Everyone wear's a smile on his face. I found exceedingly little surliness; the motto which I adopted, "Wear" a smile on your face and a flower in 
your buttonhole," admirably suited the temperament of all, although the island was passing through a period of great depression. The sanitary inspectors with whom I had worked every day during March all came down in a body to the steamer to see me off, as also did my two companions, Mr Yearwood and Dr Hutson, and my most kind host and hostess, the Governor Sir Gilbert Carter and his wife.

I sailed forth bearing with me nothing but the most pleasant recollections, and an intense wish to do all in my power to render the health conditions of their beautiful island second to none in any quarter of the globe; and I firmly believe this can be done, and it is with that conviction and in that spirit that $I$ have ventured to make the suggestions and criticisms which I have done in the preceding chapter. 


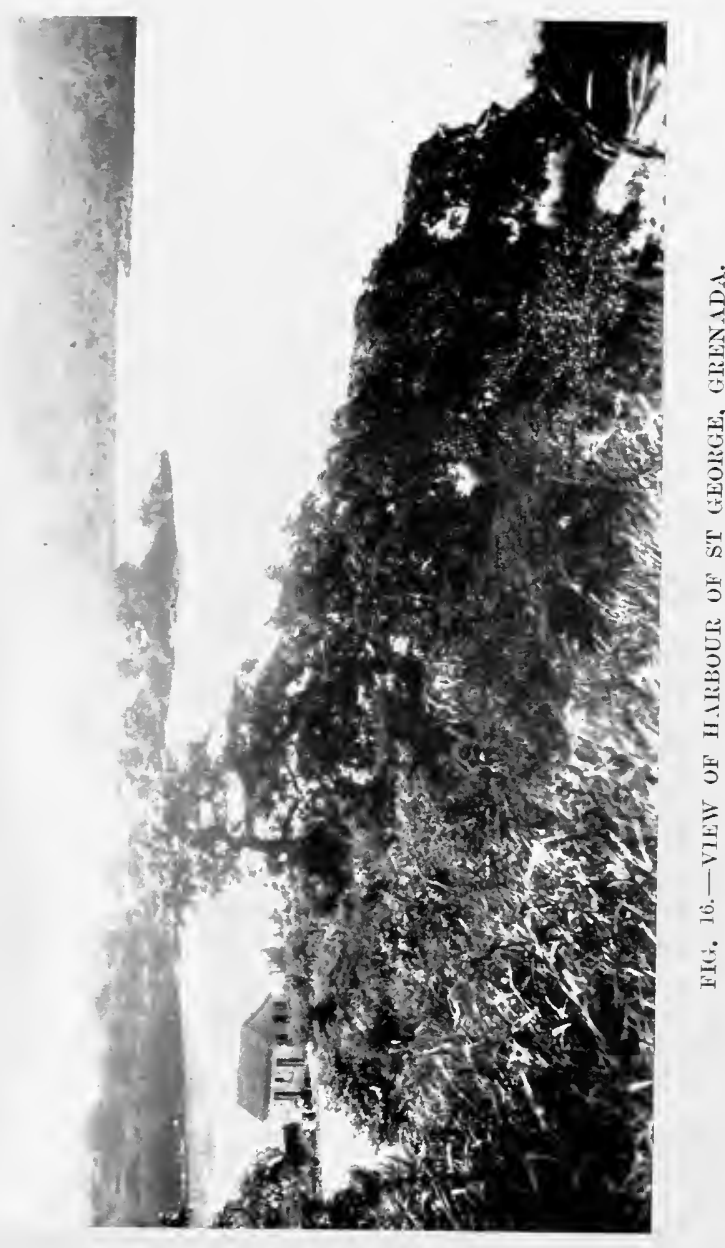

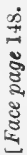





\section{CHAPTER XI}

HEALTH PROGRESS AND ADMINISTRATION IN GRENADA

ON 1st April I arrived in Grenada: I confess it, with considerable emotion. Sir Frederick Treves, in his Cradle of the Deep, has pictured to us the stout hearts which our ancestors must have had to brave the life on sea in the days of the sailing-ships; he has pictured to us the awful discomfort of the sea passage of the sailing-ship of those days. Well, here I was, now landing in Grenada after a most enjoyable voyage in the R.M.S.P. Company's ship Tagus, with all the modern comforts of a well-found craft, splendid cuisine and sleeping accommodation, and only thirteen days from Southampton to Barbados. Yet only a few decades before, my mother, then a schoolgirl, had set out on a sailing-ship to join her sister in Grenada-a voyage of nine weeks, and faced what food! and what accommodation! She used to describe to me how, often, the few passengers on board had to hold their noses when they took a cup of tea-no frozen nor condensed milk was ever heard of then; and to make the misery still worse, the usual ships' fever, "Yellow Jack," broke out, and one by one the crew were consigned 
to the deep, and then finally they had to face the ordeal of the quarantine of those days.

Grenada is a beautiful island, rendered all the more striking by contrast with Barbados. Barbados, with its gay freshness and brilliancy and slight elevationGrenada, more solemn, with green everywhere, hills and valleys covered with cacao plantations and trees of all kinds. When we landed, St George's was not a hotbed of fever ; it was as free from the danger of yellow fever as Southampton. Yet, when my mother was there her sister had just got over the usual attack of the acclimatising fever of Grenada. Yellow fever was then endemic, as well as in all the West Indian Islands, as we have seen. The colony was also, moreover, in those days badly plagued with malaria; one sister got yellow fever, the other-my mother-malaria, both within a few weeks of landing. And this was the usual occurrence at that period. But to-day how different!

It is clear, from examination of the old military records, that yellow fever was probably endemic up to the fifties, when it appears to have died out.

In the year 1817 the mortality of the troops from yellow fever is given as 8.2 per cent., and in the year 1818 as 21 per cent.

An extract from the Blue-book of the year 1881 shows that a few cases of the endemic fever occurred which, from the description, appear to have been cases of yellow fever. Mr Edward Drayton, of Grenada, also confirms this from personal recollection.

Since then the cases which have occurred have been 


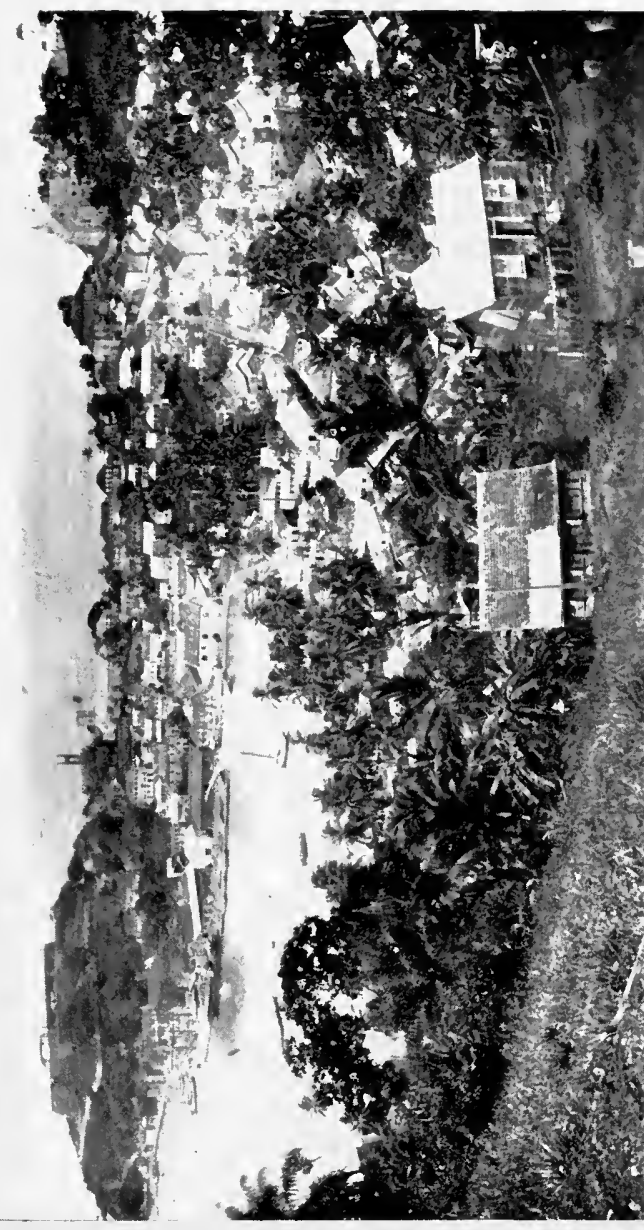

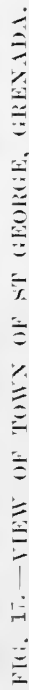



all imports. There is no longer question, therefore, that yellow fever has died out, and in my opinion the great factor which has led to this has been the introduction first in 1837 of a pipe-borne water-supply. This water was laid on to only four standpipes and not to any houses. It proved inadequate and was augmented in the year 1879 , and later again in 1907 , and now there are thirty standpipes and 240 house-services in the town. I think that there can be very little doubt that the ample pipeborne water-supply of 1879 was the death of endemic yellow fever, as also of the diseases contracted through drinking the polluted well-water of the old period.

How yellow fever was supposed to have arrived in Grenada in the 18th Century.-The following curious and interesting narrative dates back to 1793 . Dr Chisholm, a well-known writer on yellow fever of that period, gives it as his opinion that up till then all cases of yellow fever in the West Indies had arisen from marsh miasmata and were not contagious. In 1793, however, a nova pestis, "a peculiar, original, foreign plague, recently generated and utterly unknown before, endued with a distinct character, possessing new powers of devastation, and capable of propagating itself throughout this world," was introduced into Grenada on 19th February 1793, by a ship which possessed the doubtful name of Hankey. The new disease did not stop at Grenada, but Grenada became from that date the centre from which yellow fever spread, not only throughout the West Indies, but to Europe and America as well.

The wanderings of the good ship Hankey are thus 
narrated. She left England in April 1792, in company with the ship Calypso. She was chartered by the Sierra Leone Company, and had a cargo of stores and adventurers who were seeking to found a settlement in the island of Bulama, near the mouth of the Rio Grande, on the West African coast. On arrival at Bulama, the adventurers on board found they could not go ashore, on account of the bloodthirsty and cannibalistic tendencies of the inhabitants. They were obliged, therefore, to live on the ship to the number of 200 , including men, women, and children. Some malignant fever soon broke out amongst them, and when ultimately she had to leave, there was only the captain, mate, and two seamen left alive to navigate the ship. She put to sea for the West Indies, and on the way fell in with a warship, from which assistance was obtained, with the result that the fever also broke out on the warship-at least, so it is narrated. At last, when the Hankey arrived at St George's, all those who went near her also got fever. Then about the middle of April 1893, the disease began to appear ashore, introduced, so the narrative states, by a negro wench who took in sailors' clothes to wash. The disease then spread to the garrisons and held sway during May, June, and July, and from Grenada the clisease was carried to Jamaica, St Domingo, and Philadelphia. Such is the history of the introduction of yellow fever-Bulam fever-into Grenada and other West Indian islands by the fateful ship Hankey.

The introduction of the pipe-borne water at once did away with the old-time rain-water barrels, concrete 


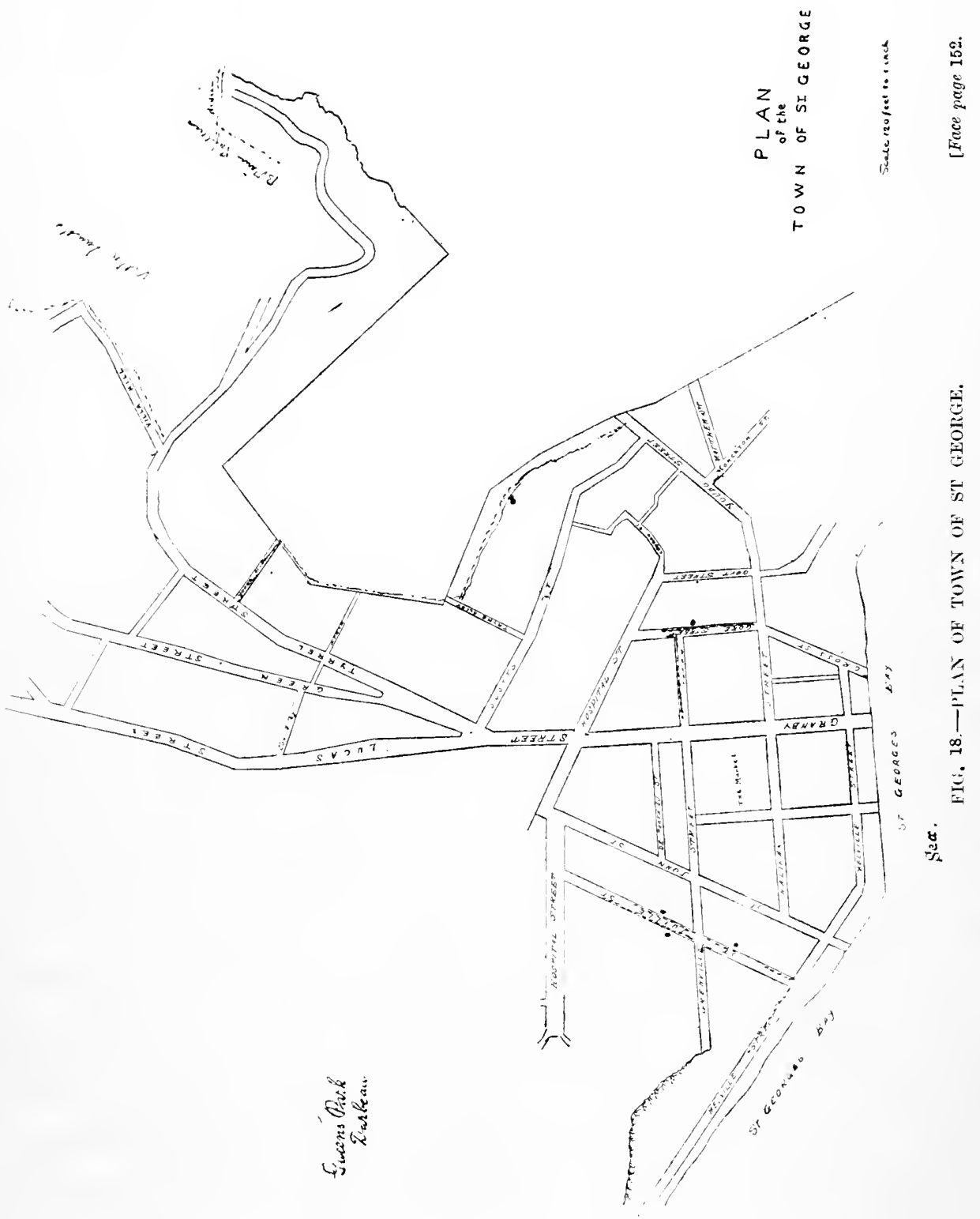



cisterns, wells, and all the odds and ends for storing water.

And in St George's, owing to the steep inclines, there is a comparatively good flushing of all drains, and there is in consequence no tendency to the formation of pools.

And there seems little doubt that St George's has been as remarkably free from Stegomyia for some considerable time past as it is to-day.

Stegomyia Survey.-I started my survey on 1st April, setting out with the Medical Officer, Dr G. W. Paterson, $\mathrm{Mr}$ Anthony De Freitas, and Inspector Smith and Sergeant Briggs. Our first tour of inspection embraced the houses of the poor and very poor ; later we examined those of the better class. Altogether, I examined 80 houses in St George's. These contained 116 receptacles, consisting of barrels, washtubs, jars, kerosene tins, and receptacles for flowers, such as calabashes, glass vases, etc. The tubs and barrels were for the most part clean; the worst offenders were glass vases, used for striking croton cuttings. I found larvæ of Stegomyia calopus in five out of the eighty houses. From this it is evident that the total number of water receptacles is not great, the house taps and standpipes having done away with the necessity of storing water, and the proportion of Stegomyia is very small. This is one great reason why Grenada has escaped yellow fever.

Yellow Fever.-Two imported cases of yellow fever occurred in 1907 ; both had come from Trinidad, and the evidence is in favour of their having contracted the disease in Trinidad in the spring of 1907 ; one was in a white, the other was in a black subject. The cases 
were properly dealt with, and no secondary cases occurred.

Antilarval and Yellow Fever Measures.-Under the Public Health Ordinances, 1902 and 1905, regulations were made, 24th April 1907, to deal with yellow fever, in respect to early notification, fumigation, and the prevention of the breeding of Stegomyia larva; these measures were hastened on, owing to the outbreak of yellow fever in Trinidad. On 30th August 1907, a further regulation was issued for the prevention of yellow fever. Since my visit, May 1909, useful regulations dealing with mosquito lar'væ have been passed, making it a punishable offence to have mosquito larvæ on the premises, forbidding the keeping of stagnant water, and insisting upon screening. The regulations also recommended the use of larvæ-destroying fish. (For further details, see Appendix.)

I visited the small yellow fever isolation hospital; it is small, but thoroughly well screened and efficient.

\section{Health Administration.}

Population.-Estimated at 71,504 on 31st December 1907.

Division of Island.-The colony is divided into six parishes, and in addition to these there are certain small dependencies, known as the Grenadines, of which the largest is Carriacou. The following is a list of the parishes :--

St George's.

St David's.

St Andrew's.
St Patrick's.

St Mark's.

St John's. 
There are ten medical districts, in charge of the following officers :-

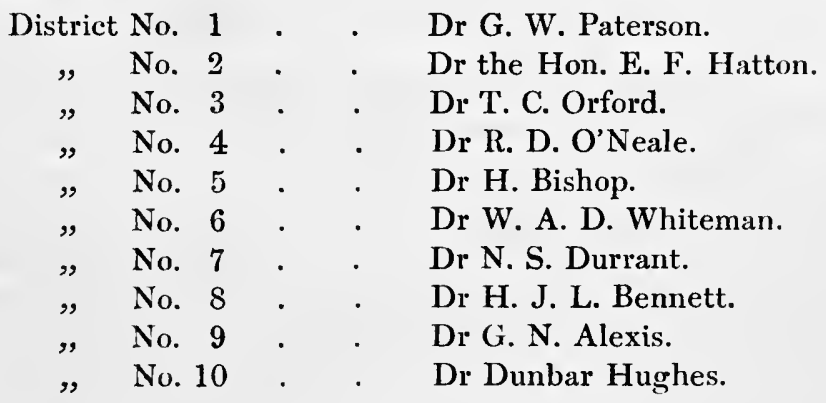

There is also a house-surgeon at the colony hospital in St George's, who is, at present, Dr J. V. de Coteau.

Principal Towns.-The principal towns are :-

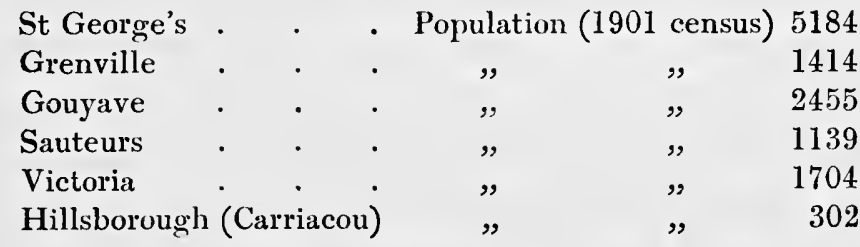

There is a board of health.

The Governor and the members of the Executive Council form the general board of health of the colony. There are six district health authorities, consisting of the medical officer, the chief and subinspectors of police and other official and unofficial members. Fixed monthly meetings are held. Excellent annual medical reports are made to the Colonial Secretary from each of the districts by the medical officer in charge, as also of all the charitable institutions. 
Yearly reports of the Registrar-General are also published, and include births, deaths, and marriages.

There are two Public Health Ordinances, 1902 and 1905 , and upon the authority of these, regulations and bye-laws have been issued.

The St George's District Board has framed sanitary and rubbish bye-laws, dealing with :-

1. Removal of night-soil.

2. Closets.

3. Offensive matter.

4. Purifying houses; and

5. Adulteration of milk (Appendix).

A very useful handbill has been issued by the St George's District Board of Health, pointing out the danger of unboiled water and flies in connection with the spread of typhoid and dysentery.

A memorandum was also issued by the Governor, drawing the attention of district medical officers to the importance of furnishing monthly returns of infectious diseases, in order to help to stamp out all such sickness. Their attention was also drawn to malarial fever's.

Malaria.-In Barbados we have seen that there is an ideal porous soil which prevents the formation of small puddles, and that the ponds which exist are well stocked with fish. I mentioned that there were no Anophelines, and that endemic malaria did not exist. What a contrast is Grenada! a stiff clay soil, numerous hills and valleys, the whole island threaded with streams innumerable, and here and there a marsh. It is not, therefore, to be wondered at that Anophelines are present 
and that Malaria is the chief disease of the island. It seems incomprehensible that there should be still doubters of the mosquito doctrine when two parallel natural experiments like Grenada and Barbados exist side by side.

I have made up, from various sources, the following annual malarial death-rates :-

\begin{tabular}{|c|c|c|c|c|}
\hline 1899 & 71 deaths & 1904 & 99 & deaths \\
\hline 1900 & $80 \quad$, & 1905 & 110 & \\
\hline 1901 & 75 & 1906 & 175 & ", \\
\hline 1902 & 115 & 1907 & 120 & ", \\
\hline 1903 & 110 & & & \\
\hline
\end{tabular}

Malaria is most prevalent in the rainy season.

In 1907, Dr G. W. Paterson, in his annual report for No. 1 District, St George's, states that there was a marked reduction in the number of cases compared with the previous year'; thus in 1907 there were 317 cases and 12 deaths, as against 681 cases and 22 deaths in 1906. In this district the chief sources of malaria are the marsh lands in the Tanteen and Queen's Park. In the same No. 4 District malarial fever was severe in 1907 . In the No. 6 District 1119 cases of malaria are reported. In addition to the endemic malaria, there is also a virulent imported form. Drs N. S. Durrant and H. J. L. Bennett, who have taken particular note of this, believe that the returning labourers have brought it back with them from Panama. If this is so, it is interesting, because in all human probability these same workmen would have had the malaria common to Grenada in their childhood or at some time prior to leaving for the Canal zone, but were not rendered immune thereby. 
Antimalarial Measures.-The first offensive blow to the Anophelines was the introduction of a pipe-borne water-supply to the towns of St George's, Gouyave, and Grenville, which did away with odd collections of water. In the second place, more land has been put under cocoa, and this has necessitated better drainage, and I have been informed by planters and doctors that since cocoa has replaced cane, there has been an improvement in the number of malaria cases.

Thirdly, the Government and the district medical officers are alive to the necessity of action, and are now only kept back through want of funds. The following circular was issued to district medical officers in July 1906, requesting them in future to include in their annual reports the mention of any measures taken to eradicate malarial fever. It runs as follows :-

I am directed by His Excellency the Governor to communicate to you the following extract from a circular dispatch from the Secretary of State for the Colonies, dated 6th June 1906, respecting the manner in which reports of the measures taken to eradicate malarial fevers, etc., are in future to be dealt with :-

3. It has been contemplated to issue annually a report of the work done by means of the funds subscribed by certain Colonies and Protectorates, and administered by the Advisory Board of the Tropical Disease Research Fund, which was constituted by my predecessor. I would suggest that the Advisory Board should utilise in their anmual report, which would be issued early in each calendar year, any reports on the measures taken to eradicate malarial fever, yellow fever, and other mosquito-borne diseases, which Colonial Govermments may be able to supply. The report of the Advisory Board will be for the academic year 1st October to 30th September, and it would therefore be sufficient if a section dealing with these measures could be inserted in the usual annual medical report of each Colony or Protectorate which is, or should be, always received at the Colonial Office before the autumu of the succeeding year. 
4. This special report or section of a report would be supplementary to, and not in substitution for, the returns now included in the annual report. It should give a concise account of the nature and cost of all measures of the kind indicated which have been begun or were in progress during the period in question, whether by legislation, public works, education, sanitation or otherwise, and it should, if practicable, give figures showing the comparative salubrity of different localities, and the varying rates of death or disease from malaria, etc., among the several classes of the community. Any really accurate and trustworthy figures as to the results of precautions taken against mosquito-borne infection should be of value.

I am to request that in future in your annual report you will be so good as to include mention, in the manner indicated, of any measures taken in your district.

Edward Drayton, Colonial Secretary.

In company with Dr Paterson, I inspected the Anopheline breeding grounds in the St George's District, viz., the Botanic Gardens, and the Tanteen and Darbeau swamps. There is very little doubt that canalisation of these swamps, and the admission of sea-water and fish, would do much to flush and drain them and to rid them of larvæ. On 1st April 1909, "millions" were introduced from Barbados into the Botanical Gardens, to deal with the water collections there.

As Grenada has done so remarkably well in connection with yellow fever, I do hope it will be encouraged to continue the fight against the Anophelines, and so render Grenada one of the most fertile, and at the same time most healthy, of the agricultural stations in the West Indies.

Grenada is the chief of the three Windward Islands, and coming from Bardados, the change to colonies where order prevails in the medical adminis- 
tration is very striking. There are annual medical reports, and one can see at a glance what is being done to reduce sickness rates, what use is being made of the medical institutions, and so on. The medical reports are well reasoned out and clearly drawn up. The medical organisations of Grenada, St Vincent, and St Lucia are not expensive. It is not too much to say, that owing to their existence, the few imported cases of yellow fever which did occur, did not spread as they undoubtedly did in Bardados. In this respect alone the three Windward Islands would have recouped themselves over and over again for the necessary expenditure on the medical staffs. Further, useful medical investigations have been made upon diseases of immense importance to these colonies. In Grenada I visited the Yaws Hospital, where patients are carefully watched and treated, and in the general hospital I saw many cases of ankylostomiasis.

In January 1908, the Colonial Secretary issued a copy to district medical officers, of the Secretary of State's dispatch relative to measures taken against ankylostomiasis in the colony (see Appendix). The disease has fortunately not assumed serious proportions.

Plague.-The administration, determined to be forearmed, have taken wise measures against rats. A circular was issued in June 1908 to district boards, pointing out the relationship of rats to plague, and the steps which should be taken to exterminate them. At the same time, rat virus and rat traps were imported (see Appendix). No cases of plague occurred.

Modified Smallpox and Eruptive Fever and Vaccina- 
tion.-For interesting information upon these diseases, see Appendix.

Tuberculosis.-Attention is directed to the extreme reluctance of the natives to ventilation, and in consequence, to the still considerable prevalence of the disease. 


\section{CHAPTER XII}

HEALTH PROGRESS AND ADMINISTRATION IN ST VINCENT

I ARRIVED in St Vincent on 6th April, and immediately established my office, with the permission and kindness of the then administrator, His Honour E. J. Cameron, C.M.G., in Government House.

St Vincent.-Estimated population (on 31st March 1908), 51,779.

The island is divided into six parishes, as follows:Charlotte Parish comprises the lands extending from the river called the Iambou to Kingstown North River, where it empties itself into the sea, and running up the bed of the last-named river until it divides, and from thence continuing along the course of the northern branch of the river to the great ridge of mountains running through the centre of the island of St Vincent.

St Andrew's Parish comprises the lands extending from the river called the Kingstown North River, and from the southern branch thereof unto the high ridge to the northward of Queen's Valley, which divides the Valley from Rutland Valley, and rumning along the ridge until it meets the great ridge of mountains which runs through the centre of the island of St Vincent. 


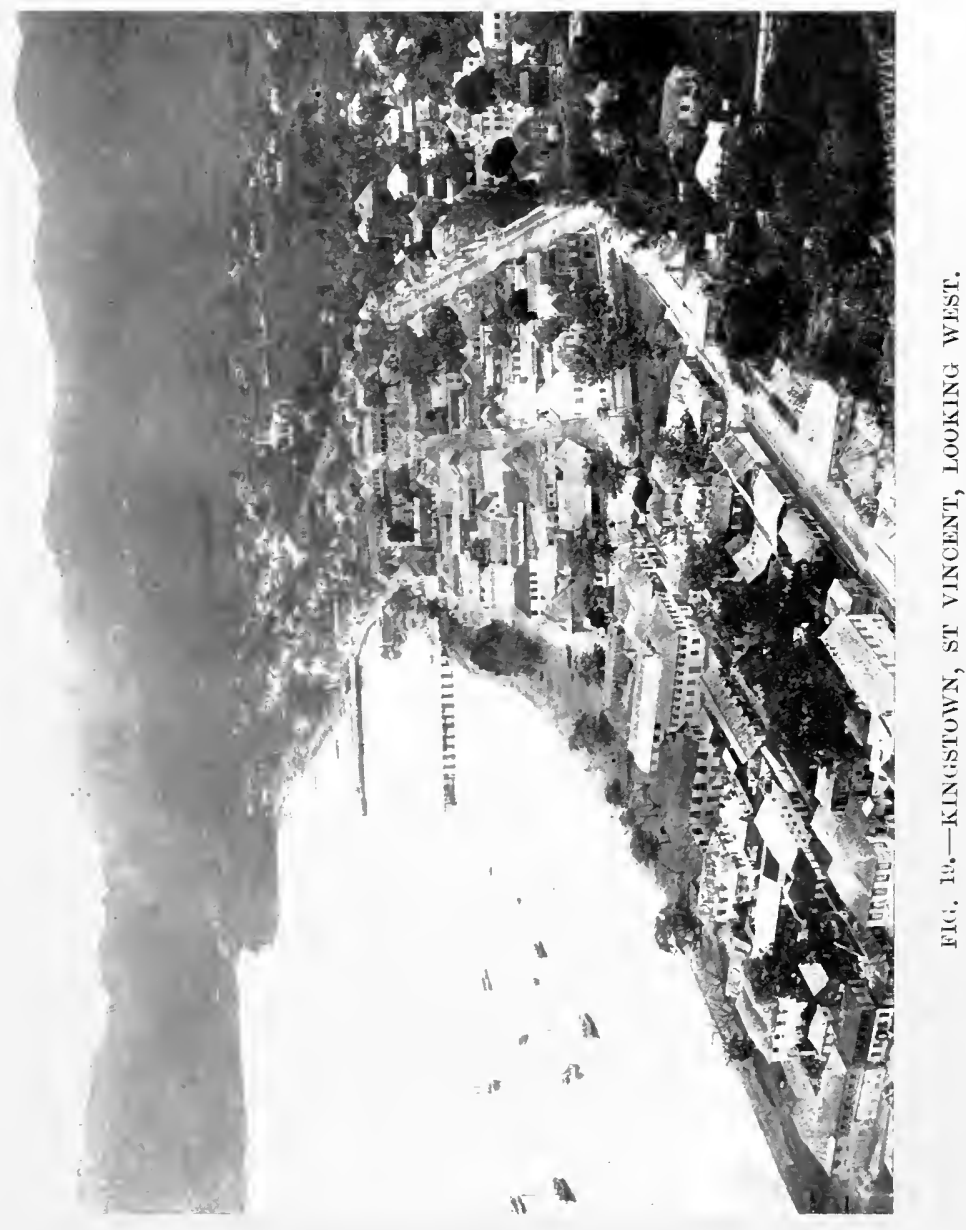

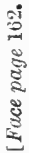

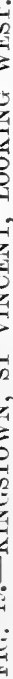



St Patrick's Parish extends from the ridge to the northward of Queen's Valley unto the high ridge to the northward of Cumberland Valley, commonly called Byam's Hill, and shall run along the last-named ridge until it meets the great ridge of mountains which runs through the centre of the island of St Vincent.

St David's Parish extends from the last-mentioned and northern boundary of St Patrick's Parish unto the northern boundary of Charlotte Parish.

The Grenadines Parish comprises the island of Bequia and such other of the islands within this colony, commonly called the Grenadines, as lie to the northward of the island of Carriacou.

For medical purposes the colony is divided into six districts, as follows :-

Kingstown District. To comprise the town of Kingstown as defined by section 73 of Ordinance No. 11 of 1897, and that part of St Andrew's Parish which lies to the south of the road leading to Fort Charlotte.

No. 1 District. That part of St George's Parish other than the town of Kingstown which lies to the north and west of Glen River and south of the Vigie Ridge, also the town of Calliaqua and area within a radius of 440 yards from the Police Station in that town; the Parish of St Andrew, south of ridge running from Biaha point to Mount St Andrew, separating Buccament Valley from Clare Valley, etc., but exclusive of that portion of the parish included in Kingstown District, also the islands of Bequia, Mustiquc, Balliceaux, and Battowia.

No. 2 District. The Parishes of St Patrick and St 
David and such part of the Parish of St Andrew as is not included in the Kingstown and No. 1 Districts.

No. 3 District. That part of St George's Parish not included in No 1 District; and portion of Charlotte Parish lying to south of a line formed by the spur which runs from the Petit Bonhomme dividing Greigg's Settlement from Mesopotamia Valley to source of Biabou River, thence following that river to the sea, and embracing the whole of the Mesopotamia Valley.

No. 4 District. The remainder of Charlotte Parish.

No. 5 District. The Grenadine islands included in the Government of this colony other than those included in the No. 1 District.

The principal towns are :-

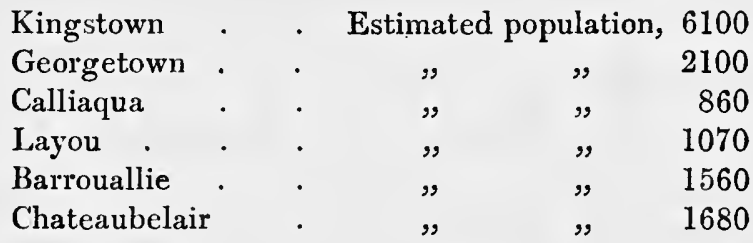

\section{Medical Organisation.}

Each district government has a medical officer, appointed by the Administrator, on selection (in the case of those purveyed from England) by the Secretary of State for the Colonies. The following is a list of the present medical officers :-

$$
\begin{aligned}
& \text { Kingstown District . . Dr C. H. Durrant. } \\
& \text { District No. } 1 \text {. . . Dr Dodds. } \\
& " \text { No. } 2 \text {. . . J) P. F. Cremona. } \\
& \text { " No. } 3 \text {. . . Dr P. Gray Marshall. } \\
& \text { District No. } 5 \text { is visited. }
\end{aligned}
$$




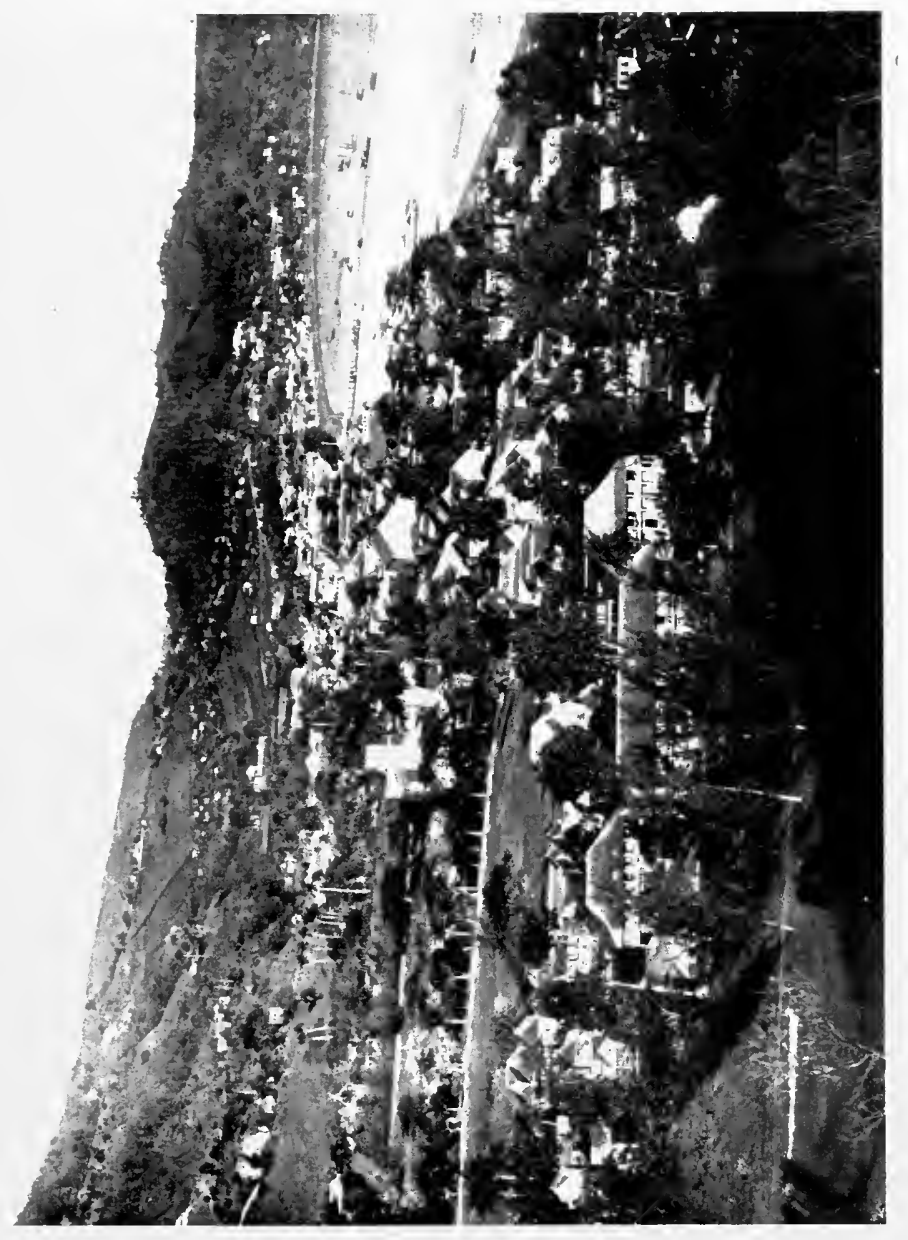

落 

The No. 4 District is at present vacant, owing to the recent death of Dr C. R. Pike; the medical duties of the district are, however, performed by Dr Cremona.

Dr C. H. Durrant is therefore the medical officer of the principal town.

\section{Health Administration.}

On 6th April, I met the Kingstown Town Board, which acts as the local health authority for Kingstown.

The chairman of the Board is $\mathrm{Mr}$ W. C. Forde, and there are four other members.

The warden is Rosemont G. Cropper.

There are two permanent inspectors-the warden and the supervisor.

In emergencies, four to six additional inspectors are appointed.

Thus it will be noticed that whilst Dr Durrant is principal medical officer for Kingstown, there is also a local health authority for Kingstown.

Public Health Acts, Ordinances, etc.-As the Public Health Act of 1865 did not contain clauses relating to mosquito destruction, an Ordinance, No. 3, of 1901, was passed to repeal it, and regulations were framed in 1907 to deal according to modern methods with yellow fever and mosquitos. A new ordinance is now being prepared for 1909 with provisions against stagnant water and larvæ; also with provisions relating to the proper storage and control of water, the notification and the prevention of the spread of infectious diseases. 
Non-compliance with the antilarval regulations is visited with a penalty not exceeding $£ 20$.

It goes without saying, that, like all the other sister islands, St Vincent is very beautiful. The valleys and the hills are well covered with woods, and numerous streams pass through the valleys on their way to the sea. In Barbados I visited all the parishes throughout the island on motor car, in Grenada I drove through the island from St George's to Grenville, in both cases getting a good idea of the nature of the country. In St Vincent, by means of a rowing boat, in company with the late Dr Branch, I was able to get a good view of the contour and nature of the island on all sides. There is evidence of past volcanic activity; every stratum tells its tale. The chief town, Kingstown, is clean, and what I have said of St George's and Bridgetown holds equally good for Kingstown, St Vincent.

The old-time fever den is now a thing of the past. Yellow fever is not endemic; although, as we have seen in the early chapters, time was when it was always recurring.

In 1817 the annual percentage mortality from fever in the garrison is stated as $\mathbf{1} 12$. In 1822 one case of yellow fever is reported, etc.

The Yellow Fever Outbreak, 1909, and the Measures taken to Stamp it Out.-Five cases were reported: four in Kingstown and one in the village of Bequia.

With regard to the origin of these cases, Dr Branch was of opinion that a mild case of yellow fever was imported from Barbados in one of the numerous schooners which trade between the two islands. For 
although yellow fever was not reported from Barbados at the time when the first two suspected cases were seen, it was so very soon afterwards (12th October 1908). He states it was unlikely to have been introduced from Trinidad or Martinique, as these places are about three days' sail, whilst Barbados is only fifteen hours' sail, and there is no trade with Martinique. Trinidad is not excluded, however, but Dr Branch thinks it improbable. Dr Durrant also states that it would have been unlikely for a case to have come from Trinidad, as at the time there was a very rigid examination of all arrivals from Trinidad, owing to the fact that there was plague; it would, therefore, have been improbable that a case of fever should have escaped the medical inspection.

In view of the facts and the smallness of the outbreak, it is most reasonable to suppose that yellow fever was introduced; it was kept small and soon extinguished. And for the promptness with which it was dealt with, we must here, as also pointed out in the case of Grenada, thank the more perfect and up-to-date medical organisation.

The precautionary measures taken were as follows :-

Disinfection and Precautionary Measures.-

CAse No. 1.-The house and shops underneath were fumigated on date of death, 10th September. The adjoining houses were fumigated the next day. Contacts were kept under surveillance. House-to-honse visitation was carried out in two blocks of the town, in the neighbourhood of the residence. On 11th September, and on the same and following days, the sanitary inspectors went through the whole of Kingstown directing 
and enforcing the clearing of bush, trimming of trees, clearing-up of broken bottles, etc., etc.

CASE No. 2.--The house was fumigated on date of death, 10th September, as also the adjacent house. Contacts were kept under surveillance. The yards of the adjacent house were cleaned up, and all likely mosquito breeding places attended to.

CA.SE No. 3.-The house was fumigated on 2 nd October, the adjoining houses on the next day. Contacts were kept under surveillance. House-to-house visitation in the neighbourhood was carried out on the 13th and on 18th October.

CASE No. 4.-Patient was isolated in his own room by effective mosquito screening on the 24th October, and the rest of the house was sealed and fumigated on the same day. Contacts were kept under surveillance. Adjoining houses were fumigated on the 25th October.

Case No. 5.- The house in Kingstown in which the patient died was not fumigated, as the period of infection had passed when the patient was brought in. The medical officer, Dr Durrant, visited Bequia on the 16th and 17th December and fumigated the house in which the patient had been taken sick, and another house to which she had been removed during the illness. He also oiled a water cistern at the former house. Contacts were examined on both days and found well. He also drew the attention of the local health authority to other necessary sanitary precautions. He made enquiries as to origin of infection, but was unable to trace anything that would throw light on the subject. 


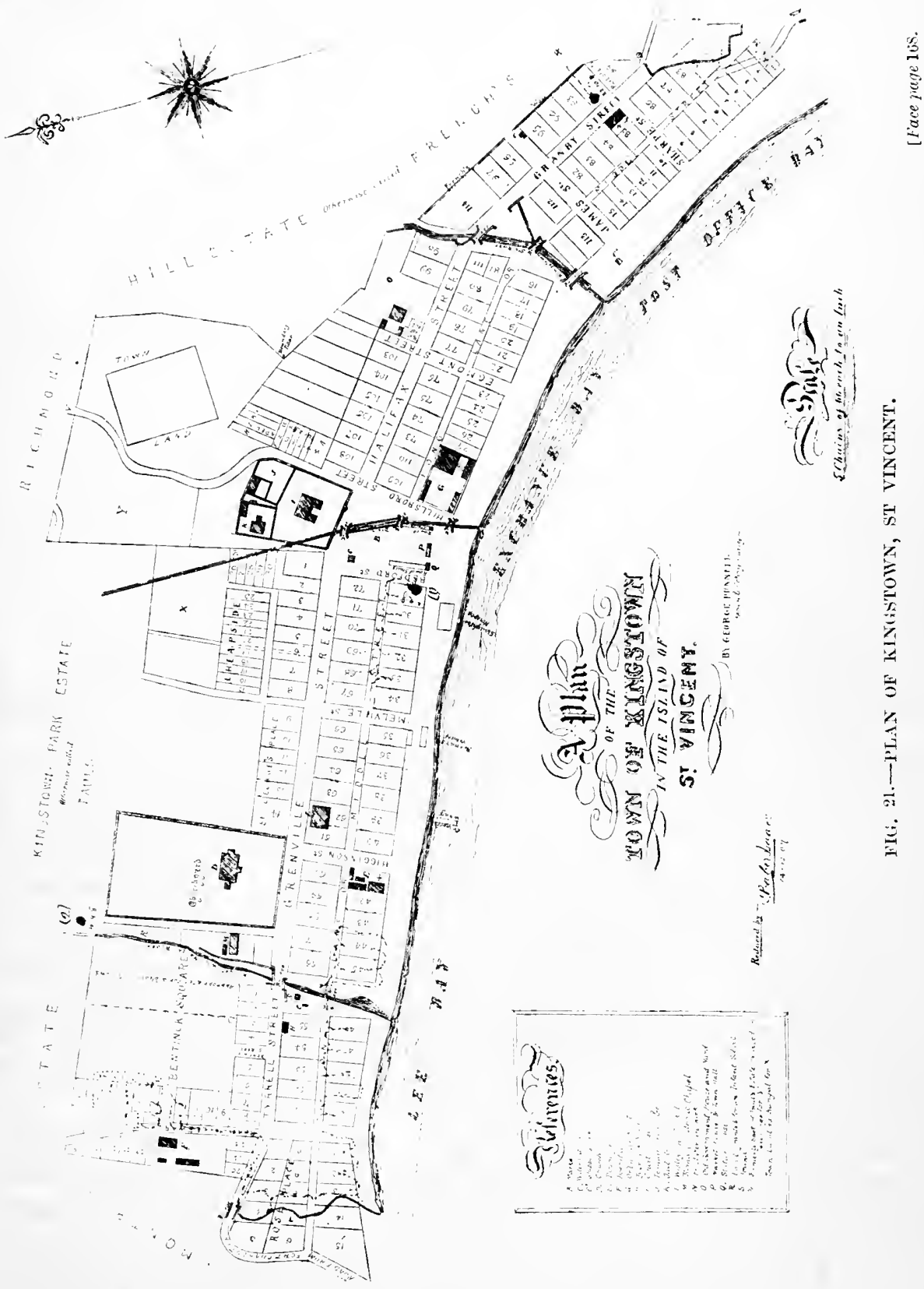



On the 28th and 29th December, Dr Durrant again visited Bequia, examined contacts, and found them free from symptoms of infectious or contagious disease. Further enquiry failed to discover a single case of fever.

There is provision in the Colonial Hospital for the isolation of cases of yellow fever. The screened ward, which I examined, was in every way effective.

At the quarantine station there is also a wellscreened house. There is in addition an excellent observation station for suspects.

\section{Mosquito Survey-Kingstown.}

I inspected 39 houses situated in Bentinck Park, in the Square, Rose Place and Lime Kiln Bay, Queen Street and Middle Street.

The yards were, on the whole, clean, containing but few odd receptacles. They had evidently been looked after. Many of the houses had standpipes, and standpipes were fixed at intervals along the roadways. The result is that the water-containers are not numerous, as there is no necessity for them. I examined 5 barrels, 12 washing-tubs, 15 jars, and 20 zinc buckets, and larvæ were found only three times. No rain-water or well-water is used systematically.

In this tour of inspection, I was accompanied by Dr Branch and the warden, R. G. Cropper, Esq.

I also visited Layou and Barrouallie, along the coast, with Dr Branch.

At Layou we were met by the warden, the Rev. Mr 
Paterson. We examined 20 houses; the yards were somewhat neglected.

The water-supply was derived from the river. No standpipes were found. I examined 6 barrels, 2 tubs, 15 jars, and 12 buckets and 5 kerosene tins, etc. Larvæ were found on two occasions.

At Barrouallie I visited two houses and examined 10 barrels, 2 tubs, 5 buckets, 8 jars, and other odd receptacles. Larvæ were found in all the barrels. The water-supply is obtained from a spring, and there are also some wells in the rainy season. Roof-water is collected. $\mathrm{Mr}$ James Gould is the warden.

It would be a great boon to introduce a proper water-supply for both places, and to appoint sanitary inspectors.

I inspected Calliaqua with Dr Durrant, and on the way examined the houses along Sion Hill. They nearly all of them have barrels for holding rain-water or drinking-water. 'The majority contained larvæ. This district was the worst part of Kingstown as regards larvæ, and this is due entirely to the fact that there are no standpipes.

At Calliaqua I inspected 19 houses. Barrels were relatively very numerous. I examined 6 barrels, 10 buckets, and 6 jars. There were also 3 wells and numerous old receptacles which would breed larvæ in the rainy season. Larvæ were present in two houses. This town is weak from a yellow fever defensive point of view. A proper water-supply is most desirable, and also a sanitary inspector. 
I visited, with Dr Branch and Warden Cropper, the market, and examined several houses and yards. I found in them 7 barrels, 7 tubs, and 3 buckets. Larvæ were found three times. The yards were for the most part badly kept and contained numerous odd receptacles. One yard contained a lot of barrels. There was much roon for improvement in this neighbourhood.

Summary of Mosquito Inspection.-Kingstown and Sion Hill :-

60 houses.

20 barrels.

19 tubs.
23 buckets.

15 jars.

Larvæ in 9 houses.

Towns of Layou, Barrouallie, and Calliaqua-

65 houses.

22 barrels.

4 tubs.

29 jars.
27 buckets.

5 kerosene tins.

3 wells.

Larvæ in 14 houses.

As in Barbados and Grenada and the other West Indian islands, so in St Vincent, it is to a modern pipeborne water-supply that we must ascribe the prevention of cholera, and no doubt also the probable extinction of yellow fever. Wells were done away with, and therefore the necessity for keeping stagnaut or roof-water ceased.

Malaria.-This disease still claims a very considerable number of the population. It is chiefly confined to certain districts, as Layou and Arno's vale. Several streams pass down from the high land at the back of 
Kingstown to reach the sea. Their mouths are liable to become blocked by the foreshore, and in addition their beds are very uneven; as a result, much puddling occurs. A considerable amount of malaria is attributed to them. The island is also intersected by numerous streams, there is a considerable growth of trees, and there exists some low-lying patches of swampland. Some of the roadside drains are also shallow and weed-grown; they require to be deepened and given better falls. I inspected Paul's Lot, which is a low-lying swampy piece of land and requires proper drainage. The expenses which would be incurred to carry out these improvements would be counterbalanced by the increase in the health of the community.

The following are the annual number of cases of malaria :-

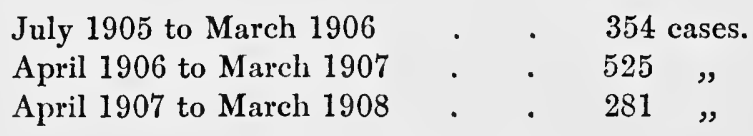

As in the other islands, so in St Vincent, entomological studies have been taken up by $\mathrm{Mr}$ Paterson of the Imperial Agricultural Department.

He and the late Dr Branch studied the question of the natural enemies of mosquitos, and made observations showing that the "water-boatman" attacks the larvæ of mosquitos by sucking them dry.

Other Diseases :-

Ankylostomiasis.-The returns show a very considerable number of cases of ankylostomiasis and anæmia. 
Tuberculosis and Syphilis also claim a very large number of victims. These two diseases have stepped in and increased, whilst the water-spread diseases and yellow fever have gone steadily out.

Filariasis.-A considerable number of cases are recorded annually. 


\section{CHAPTER XIII}

HEALTH PROGRLSS AND ADMINISTRATION IN ST LUCIA

I ARRIVED in St Lucia in the early morning of the 9th April, and had the opportunity, in the small steamer in which I travelled, of seeing the very mountainous and hilly nature of the island: it was very beautiful; and equally pleasing in another direction was the compact, cleanly appearance of the prosperous little coaling-port of Castries. The only touch of sadness was the appearance of the vast collection of magnificently constructed military quarters lying to the back of the town. They were all deserted, and it was most depressing to wander through block after block and to think that this vast expenditure of money was now all wasted. But let us hope that they may yet be utilised. Of course, this vast preparation for the garrisons recalled the time when, in common with the other islands, yellow fever was endemic in the colony and yearly demanded a heavy toll of the garrison. Yellow fever was prevalent and fatal in the year's 1818, 1822, 1824, and 1827. In 1818 the mortality was 14.5 per cent. ; in 1832, 30.8 per cent. ; in 1824 and 1827, 21 per cent. 


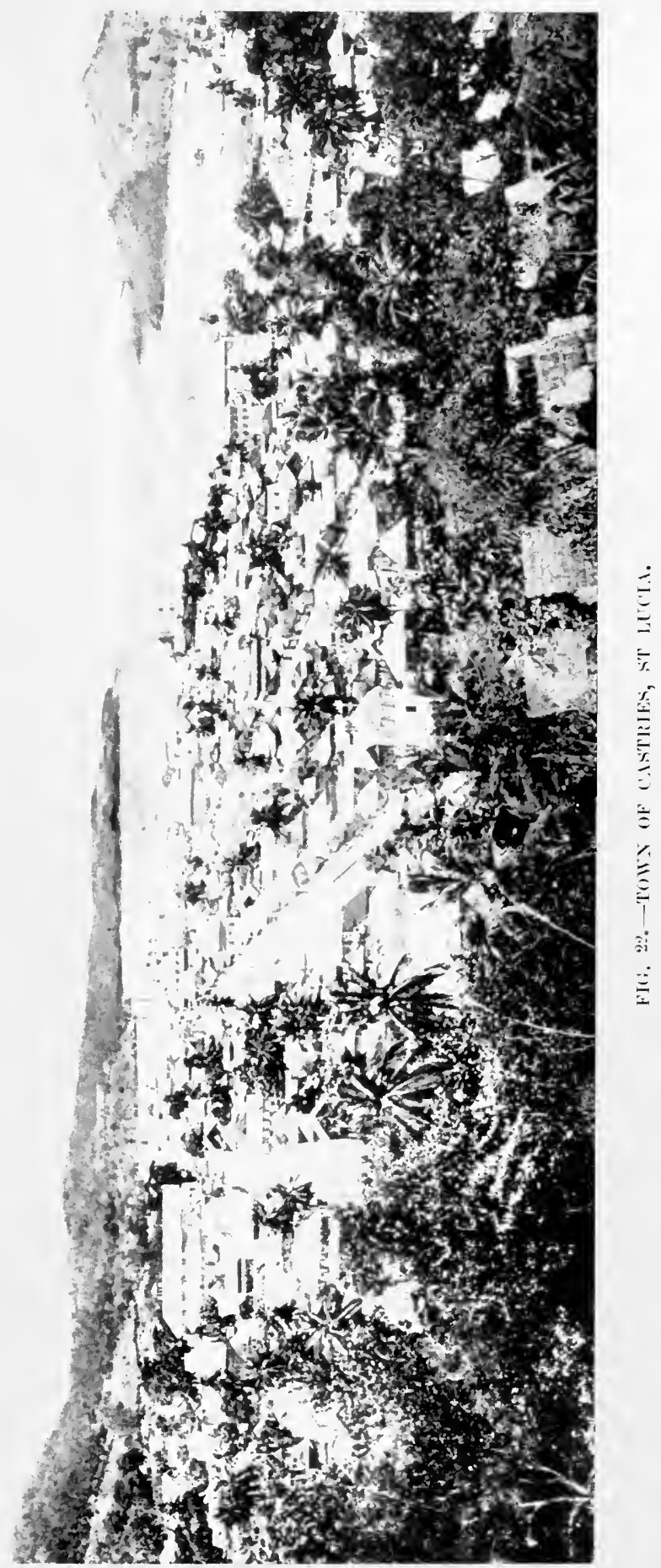



In his History of the Black Watch, Archibald Forbes has described the mortality in the campaign of 1796 , when one regiment lost 800 men in one year.

Hunter states that in the war with the French in St Lucia, 5000 of the bravest troops in the world took possession of the island with little loss from fighting, but at the end of twelve months scarcely a man was alive. To-day, were soldiers quartered in them, there would in all probability be not one case; indeed, the soldiers would be in far more bracing and health-giving surroundings than in the old country. What has banished yellow fever from the Castries? Again the answer is the same as in the case of the adjacent islands. The introduction in 1848 of a pipe-borne water-supply laid on to the houses and to standpipes along the road. This bedrock measure of sanitary reform did away to a considerable extent with the wells and barrels. With the diminution of the wells, water-carried diseases, like cholera, disappeared to a large extent, and with the lessening of the number of water receptacles, the breeding places of the Stegomyia were also reduced, and the chance of spreading the infection of yellow fever greatly diminished. In spite, however, of the modern pipe supply, there persisted a very large number of barrels and especially numbers of the old type-French and Spanish olive jars, and innumerable odds and ends which could hold water; there were also a few concrete cisterns and iron tanks. From 1905 a raid was commenced on these receptacles, and when I made my house-to-house inspection this year, I found that the large jars had for the most part been inverted, so that 
they could not hold water, or that they were placed under cover so that the rain could not get to them. Receptacles which could not be readily removed as cisterns were screened. The barrels still remaining are, I believe, also screened. A few wells still persist, which no doubt will soon be got rid of.

Public Health Acts, Ordinances, and Regulations.In 1874 an Ordinance was made to secure the health of the colony. This Act dealt with the appointment of the Board of Health; the making of sanitary regulations; the power of inspection; and the infliction of penalties. In 1881 a special Yaws Ordinance was introduced.

In 1902, regulations were made under the 1874 Ordinance by the Board of Health. These dealt with the appointment of inspectors of nuisances, the cleansing of houses and yards, and regulations dealing with towns and villages.

In 1903 a special Ordinance, entitled the "Medical Officers' Ordinance," was made to amend the law with respect to medical officers. The colony was divided into medical districts, of which there are now six; the duties of medical officers were also proscribed.

In 1907, additional regulations were formed to deal with waste and stagnant water, and all water receptacles, making it a nuisance to keep any breeding grounds for mosquitos unless screened. These regulations also proscribed the procedure in regard to yellow fever of an up-to-date character. In 1908, further regulations were issued dealing with contacts, isolation, surveillance, in connection with plague, cholera, smallpox, and yellow fever. 


\section{Mosquito Destruction.}

The following useful notice has been issued to householders in St Lucia, July 1909 :-

1. In the general interest of the public health, and particularly to prevent the introduction and spread of yellow fever, which would most seriously affect the trade of the island, every householder is invited to co-operate with the health authorities in the destruction of mosquitos.

2. It is by mosquitos that both yellow fever and the ordinary malarial fever are carried and spread.

3. Mosquitos can only breed in stagnant water; therefore you are requested to see that-

(a) Any tanks or jars or other water receptacles in your yard are screened according to the Board of Health regulations, to prevent mosquitos getting into the water to breed.

N.B.-The health authorities will be prepared to examine premises and give advice as to the proper way of screening, etc. In Castries a specimen of such screening can be seen at the police station.

(b) All wells are filled up.

N.B.-Well-water in Castries is most unwholesome.

(c) None of the following articles are kept lying about your yards or lots:-

i. bottles : whole or broken,

ii. tins,

iii. broken pieces of earthenware,

iv. coco-nuts,

v. calabashes,

or any other thing capable of holding water.

(d) All hollows in the ground about your yards or adjacent premises are filled up to the level, so that water may not collect in them. 
(e) Water kept in-

i. washing-tubs,

ii. flower vases,

iii. chickens' drinking-vessels,

is changed very frequently and the vessels kept free from moss, because the green moss found in such vessels harbours the mosquito larvæ and keeps them alive while the water is being changed.

Issued by advice of the Medical Board.

\section{H. A. Smallwood, Acting Colonial Secretary.}

From 1906 the Government has, in fact, taken systematic steps to diminish the mosquito nuisance, and they have reaped the benefit, as we shall see.

I examined the inspection book of one of the sanitary inspectors. It testified to the care with which the yards of the inhabitants of Castries were examined for the presence of water receptacles, rubbish, and especially larvæ.

The book shows that at first the inhabitants were cautioned against the dangers of stagnant water and harbouring larvæ. Finally, summonses were obtained.

After regulations were passed making it an offence to breed larvæ, the following prosecutions took place :-

$\begin{array}{rrrrrr}\text { Year } 1907 & . & . & . & & 13 \\ \# 1908 & . & . & . & & 57 \\ \# 1909 & . & . & . & & \end{array}$

The moving force which more than anything else led to the health security of St Lucia, was the active stimulus of the late Administrator, Mr Philip C. Cork. I had in 1905 the privilege of working with $\mathrm{Mr}$ Cork, when 
he was acting as Administrator in British Honduras, during the yellow fever outbreak in that colony. The line of action which he took when he subsequently arrived in 1906 in St Lucia was characteristic. He issued a memorandum to medical officers in the island, calling for returns, showing the number and description of the mosquito-borne diseases (for the previous twelve months).

The information elicited, although meagre, was exceedingly interesting (see Appendix). In the first place, it drew the attention of medical officers to the importance and significance of these diseases, and showed that the administrator was fully alive to the necessity of action. In the second place, it showed to what extent the medical officers had kept in touch with modern developments in epidemiology and mosquitoborne diseases. Thirdly, it demonstrated where weak spots existed in sanitary administration in respect of these important diseases, and where in consequence the medical machinery required augmentation. If this example were more often followed, there is no question in my mind that sanitary administration would be greatly strengthened and sickness and death-rates lowered.

Another circular was issued to the medical officers, as follows :-

GovernMent OfFice,

17 th June 1909.

Sir,- - Referring to the circular from this office dated 21st March 1907, forwarding for your information and guidance copy of additional Regulations, framed by the Board of Health under the Public Health Ordinance, 
1874, I have the honour to invite your attention to the 2nd paragraph of that circular, and shall be glad to hear from you that, in accordance with the instructions contained therein, you have satisfied yourself that the inspectors of nuisances in your district fully understand the duties required of them under the regulations, and that they are effectually carrying them out.

2. I shall be pleased also to receive a report from you on the results of any experiments that you may have made for destroying mosquito larvæ in tanks and barrels by the use of small fish, as suggested by $\mathrm{Mr}$ Cork.-I have, etc.,

E. D. Laborde.

Stegomyia Survey.-In company with Dr A. King, I visited on 11th and 12th April, 93 houses and yards in different quarters of the town, including those of the poorest classes, and those of the poor and better-class tradesmen.

In a considerable proportion of these houses there were standpipes in the yards, and if not, near at hand, in the roads; in consequence, there is no necessity for the long storage of water.

The water receptacles consist of large jars, very few rain-water barrels, but tubs for washing clothes are numerous. There are also large tanks for storing rainwater, and a few wells and concrete baths and odd receptacles. Odd receptacles are, however, not numerous. The large tanks are usually screened with wire-gauze, and the jars have for the most part been removed or placed mouth downwards, so as not to collect water. It is obvious, from the appearance of 


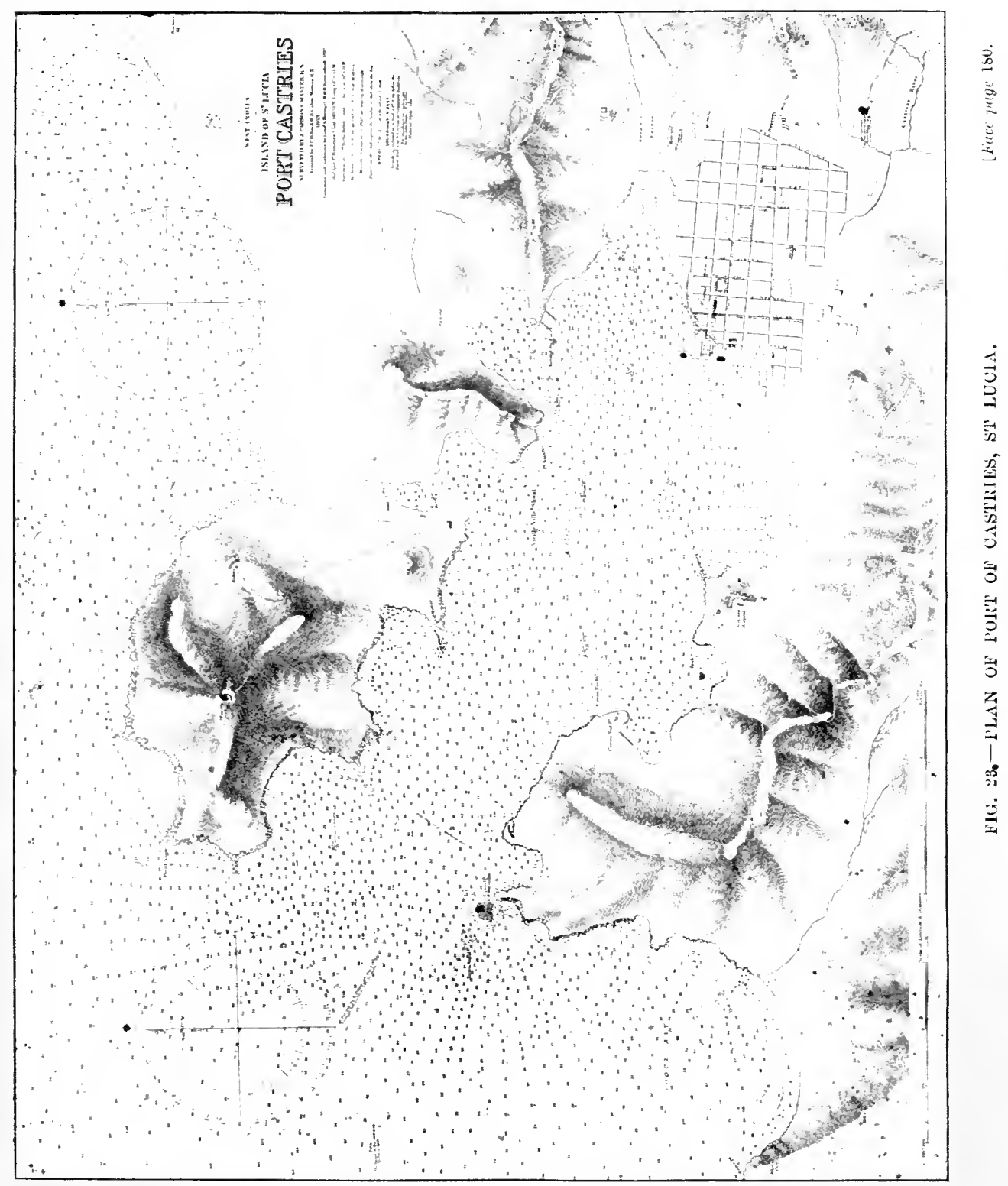



the yards, that householders have been warned of the danger of keeping stagnant water; nevertheless, as showing the importance of constant vigilance, I found numerous breeding places in the yards, but all sources could be readily got rid of.

I examined-

4 barrels.

85 washtubs.

57 jars.
36 kerosene tins.

96 buckets.

1 well.

Larve were found 28 times in the 93 houses.

History of Yellow Fever in St Lucia.-As I have stated previously, we know that yellow fever formerly regularly visited the island. Thus, in 1839, we read that yellow fever attacked the troops at Morne Fortuné from August to September, and that out of 134 white troops, 93 were attacked, and 20 died. The inhabitants, however, suffered still more severely, and the epidemic commenced earlier amongst them, in July. It is stated that the disease ceased on the occurrence of the boisterous weather and heavy rains. Some cases were, however, recorded on Pigeon Island in October. An epidemic is also recorded in 1842. In 1901, yellow fever is stated to have occurred on the Morne Fortuné and to have been due to the excavations for the railway then in progress. Since 1904 - that is, when the present principal medical officer, Dr King, arrived in St Lucia - no case has been recorded.

During the period, however, there was very considerable risk of imported cases from either Martinique, Trinidad, or Barbados. Dr King attributes the immunity 
of the island to rigid inspection of ships arriving from infected ports, both as regards the passengers and crew, and to ascertaining whether all Stegomyia had been killed on departure of a ship from an infected portin other words, whether fumigation had been efficiently carried out. The port of the island is Castries, but on the north of the island at points nearest Martinique, no doubt the arrival of small boats does occur. In time of danger a most careful watch is kept upon this part of the coast. In any case, even if a mild case had passed in, no other cases have occurred in the island during the very severe epidemic in Martinique. This is attributed to the great additional safeguard of having enforced the antilarval measures previously alluded to. We have already noted how two of the Windward Islands, Grenada and St Vincent, had a few cases each as the result of importation. Owing to the precautions taken in each of these islands, the disease did not spread. In St Lucia, the third island of the Windward group, and within only a few miles of Martinique by boat, where there was a very severe epidemic, and in constant communication with Barbados and Trinidad, where also there was yellow fever, not one case of yellow fever occurred. In my opinion the administrative and health authorities are to be heartily congratulated for having had such a good sanitary organisation. Castries is a growing coaling port, and had yellow fever occurred, it meant destruction to the principal industry of the port. In this year (1909), whilst yellow fever was present in three of the West Indian islands, St Lucia escaped altogether, and 
Grenada and St Vincent easily prevented their few imported cases from infecting their respective territories. In my opinion, no more striking example is needed to demonstrate the economy of having a chief medical officer of health, and a proper modern medical organisation. These three islands have saved in 1909 more than the cost of their medical organisations by their security from yellow fever. Surely Barbados is now in a position to study what these organisations are, and to adopt a similar system, and so avoid in future the disaster of 1909 .

Quarantine Administration.-It was especially during my stay in Castries that I was made aware of how, with the best intentions, the practical good which the intercolonial quarantine laws were calculated to bring might be neutralised or even turned to disaster by the want of organisation of one of the contracting parties.

The Administrator of St Lucia, who, as I have said before, had a thorough knowledge of yellow fever prophylaxis and quarantine administration as affecting it, was perpetually harassed by anxiety lest yellow fever should enter St Lucia from Barbados. For this anxiety he had most reasonable grounds. For, owing to the admitted unfortunate delay in making a diagnosis of the fever cases in Barbados, ships were arriving in Castries with clean bills at a time when rumour and subsequent notification clearly showed that yellow fever existed in the island. And not only this, but Dr King, who made his usual rigid examinations of the ships, reported to $\mathrm{Mr}$ Cork that fumigation had not been completely carried out in Bridgetown, for he found living 
Stegomyia in some of the ships examined. This, of course, is as serious as finding cases of the fever in man during the infective stage. An infected Stegomyia is as dangerous as an infected man, and the answer given by Barbados to Mr Cork's anxious enquiries about these matters were, in my opinion, not calculated to relieve his natural anxiety. As I have pointed out before, for producing this state of alarm in a friendly and sister colony, Barbados is, in my opinion, alone to blame, for its lack of proper medical organisation. It is, therefore, incumbent upon Barbados, in the interests not only of its own trade, but of that of the sister colonies, and the efficient working of that common-sense measure, namely, the Inter-colonial Quarantine Act, to recast its medical organisation and appoint an efficient head.

Quarantine Station.-I visited, with Dr King, the quarantine station. It is excellently arranged.

Other Diseases in St Lucia.-Annual medical reports are published, showing what the hospitals and dispensaries are doing, so that the enquirer and student can readily see what are the diseases which are most prevalent, and thus be able to better advise on the best method of preventing them.

Amongst the chief diseases are: Malaria, intestinal parasites, ankylostomiasis, yaws.

Malaria.-The island is volcanic in origin. It is very mountainous; from a central ridge or backbone numerous streams run down to the coast, numerous very fertile valleys starting from the ridge, sprear out and become flat towards the coast; these valleys, being 
well supplied by streams from the higher ground, become in the low-lying parts swampy, the soil consists of alluvial mould and clay, and tends to hold up water. Sugar is cultivated in these valleys, and malaria is common in the wet season.

I visited some marshy low-lying spots in the neighbourhood of Castries, which it is proposed to drain, and in my opinion the health conditions would be greatly improved if this was carried out, especially as there exists no insuperable difficulty in carrying out the necessary drainage operations. Owing to the prevalence of yaws in 1881, a Yaws Prevention Ordinance was made, and in 1907 a further Ordinance to cement it in certain particulars was passed.

Ankylostomiasis.-To prevent this disease from spreading, public opinion was being educated by means of leaflets, setting forth the simple methods of prevention (see Appendix).

The history of the sanitary progress of St Lucia would be incomplete without reference to the excellent work accomplished by Major Hodder. This observer has given a most excellent account of the drainage and other works carried out in 1902-3 with the object of destroying mosquitos in St Lucia. The Royal Army Medical Corps and the Royal Engineers combined to get rid of the pests by draining swamps, constructing new drains, and clearing bush. The Town Board of Castries had also from 1890 to 1900 undertaken drainage operations and had introduced the new watersupply mentioned to begin with. In Major Hodder's opinion, all these works had contributed to diminish 
malaria in Castries. Major Hodder describes the works which he undertook at Vigie, the Morne, and La Toc, at a total cost of $£ 3985$, or an annual expenditure of $£ 1782$. The figures which he gives are of very practical value. 


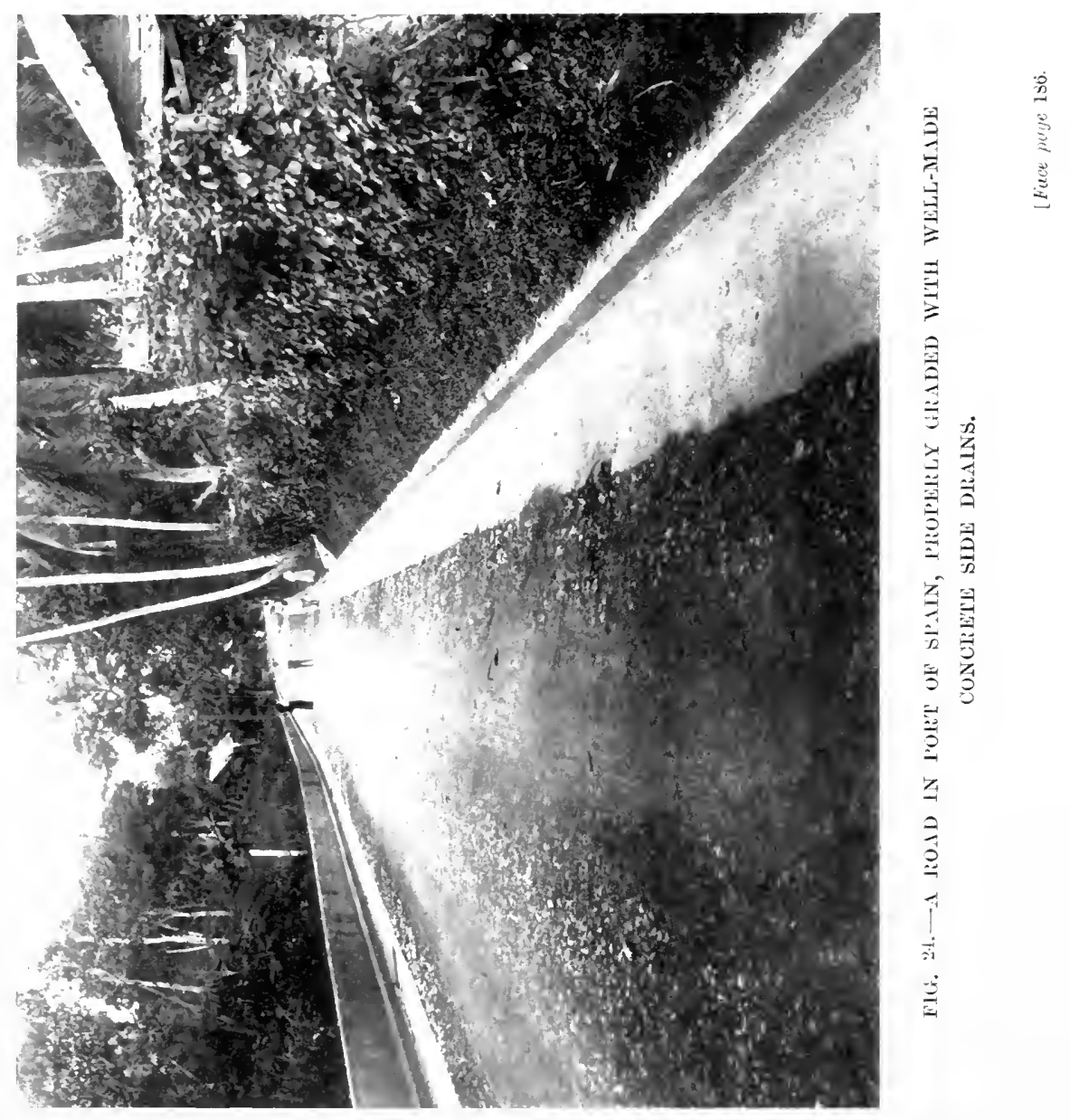





\section{CHAPTER XIV}

HEALTH PROGRESS AND ADMINISTRATION IN TRINIDAD

I ARRIVed in Trinidad on 3rd May 1909. It is a large island, with some 336,769 inhabitants ; it is very fertile, and is covered with vegetation; cocoa and cane are the staples, and rubber is now being largely cultivated, and cotton is beginning to be grown in Tobago. The island is hilly, and there are several rivers.

On landing in Port of Spain, I experienced the same feelings that $\mathrm{I}$ did in landing at the other islands. Here was Port of Spain, in every sense an up-to-date and well-found city, a city which is sometimes spoken of as the Liverpool of the West Indies. There was no epidemic passing through it, nor indeed was there any abnormal mortality. But what was the condition in the early part of the nineteenth century? We read that the mortality of our troops from yellow fever alone was 30 per cent. in the year 1818, and in 1828 it was 13 per cent., and in the six years from 1820 to 1825 it was on an average of $3 \cdot 2$ per cent. We can say that in those days yellow fever was endemic and always present, and so, we may be sure, were all the other West Indian fever's. In the adjacent island of Tobago, the 
mortality in 1818 was 13 per cent. amongst the white troops; in 1819 it was 18 per cent., and in the year 1820 as high as 80 per cent. In 1821 it was 25 pel $^{\circ}$ cent. Figures like these show that not only was yellow fever endemic, but that new arrivals were, as in all the other islands, sure to get it. And again we ask the question: What has brought about the almost complete cessation of yellow fever? The answer is the same as that given in the case of all progressive cities in the yellow fever zone-namely, the introduction of a pipeborne water-supply. This was introduced in 1851. Also, no doubt the improvements in building construction, proper drainage, and the cleansing of backyardsthe conditions, in fact, which do away with the necessity for the storage of water in barrels and odd receptacles, and which prevent the formationjof puddles-contributed in no small measure to the present-day security.

The Water-supply.--The pipe service was introduced in 1851, since which date great extension of the area supplied has taken place, and further extensive improvements are now contemplated. To the new water system we must then ascribe, as in each of the other islands, the death of yellow fever, and no doubt also the marked diminution of all those diseases due to the consumption of polluted water.

If up to the year 1825 yellow fever was the rule rather than the exception, what outbreaks have been recorded in the latter half of the nineteenth century? Outbreaks are recorded in Trinidad in the years 1889, 1891, and 1894, and the last small outbreak, which was comparatively recent, was in $\mathbf{1 9 0 7}$. These dates show a 


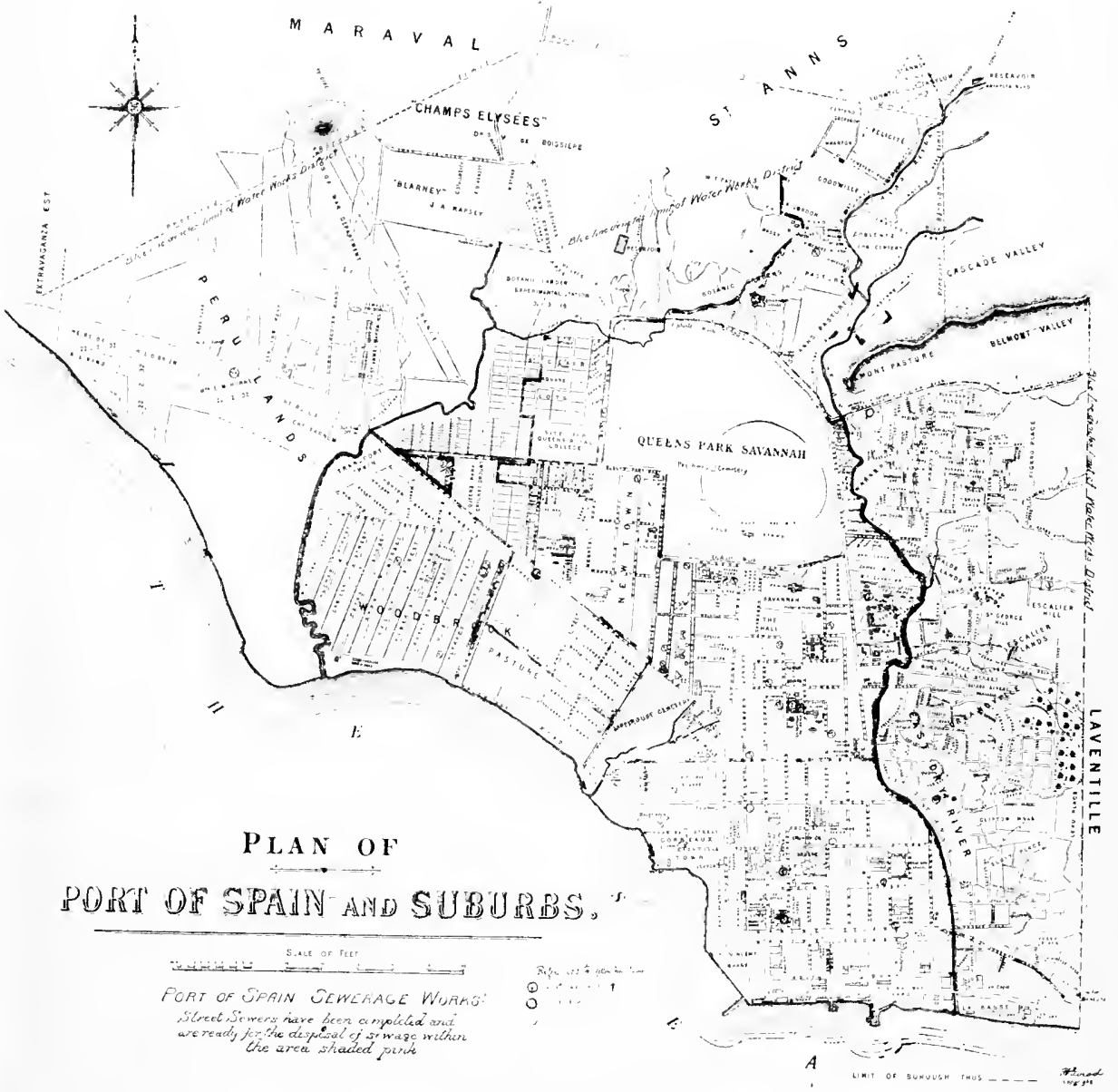

FIG. 25.-PLAN OF PORT OF SP'AIN AND SUBURBS. 

certain amount of the periodicity noted by the older writers-in this case a recurrence after intervals of twelve or thirteen years. As I have stated elsewhere, this periodicity may be related to the immunising effect of each epidemic upon the population: non-immunes are born in the intervals, and new arrivals come from other countries; then, given the importation of yellow fever, the non-immunes are picked out by the disease. But after an epidemic a large immune population is left in possession, and naturally no cases occur amongst them until the non-immunes have had time to collect again.

History and Duration of the recent Outbreak.-From the end of January 1907 to the end of March in the same year, five cases of yellow fever occurred; all those attacked were new arrivals, the type of fever was severe, and four out of the five died. Looking at these cases in the light of what we know about yellow fever, gained both from the experience of past epidemics and of recent ones, I can come to no other conclusion than that there was in the Port of Spain an area in which there was a considerable number of infected Stegomyia; and this would indicate that there had been in that area unrecognised cases of yellow fever. As in the case of Barbados, the outbreak of yellow fever amongst the newly arrived gives the impression of a "bolt from the blue." In reality it is nothing of the kind: the disease was there smouldering for a considerable time unobserved, but nevertheless able to communicate the virus to the Stegomyia, which in its turn infected the sensitive new arrival with the malignity typical of this disease; then 
the disease became patent to all. This is the usual history throughout the yellow fever zone. The first mild cases amongst the inhabitants are not recognised; the new arrival, as in the days of Blair, becomes, when infected, the first signal that anything is wrong. Cases continued to recur from March onwards to the end of August of the same year, 1907, by which time there had been 38 cases. Then a new case was found in the town of San Fernando on 1st November, and further cases developed, until a total of 47 was reached on 1st March 1908. That is to say, the epidemic lasted fifteen months, and there were altogether 47 cases, 28 of which were fatal. This represents a high percentage mortality.

Return of Number of Cases of Yellow Fever Notified, and the Number of Deaths in the Colony and in Port of Spain, for the years 1907, 1908, and 1909.

\begin{tabular}{|c|c|c|c|c|c|c|c|c|c|c|c|c|c|}
\hline \multirow{2}{*}{ Year. } & & \multicolumn{3}{|c|}{$\begin{array}{l}\text { No. of Cases } \\
\text { treated } \\
\text { in the Colony. }\end{array}$} & \multicolumn{3}{|c|}{$\begin{array}{l}\text { No. of Desths } \\
\text { in the Colony. }\end{array}$} & \multicolumn{3}{|c|}{$\begin{array}{c}\text { No. of Cases } \\
\text { treated } \\
\text { in Port of Spain. }\end{array}$} & \multicolumn{3}{|c|}{$\begin{array}{l}\text { No. of Desths } \\
\text { in } \\
\text { Port of Spain. }\end{array}$} \\
\hline & & M. & F. & T. & M. & F. & T. & M. & F. & T. & M. & F. & T. \\
\hline 1907. & & 31 & 8 & 39 & 18 & 3 & 21 & 24 & 7 & 31 & 17 & 1 & 18 \\
\hline 1908 . & . & 3 & 7 & 10 & 2 & 6 & 8 & 1 & 7 & 8 & 1 & 6 & 7 \\
\hline 1909. & . & $\ldots$ & $\ldots$ & $\ldots$ & $\ldots$ & $\ldots$ & $\ldots$ & 1 & ... & 1 & 1 & .. & 1 \\
\hline
\end{tabular}

The following statement details in tabular form some interesting features of the incidence, etc., of the disease :- 
Table showing Sex, Age, and Race Distribution of Cases of Yellow Fever in 1907-8, with Number of Deaths, Death-rates, etc.

\begin{tabular}{|c|c|c|c|c|c|c|c|c|c|c|c|c|c|c|}
\hline \multirow{2}{*}{$\begin{array}{c}\text { Total } \\
\text { No. } \\
\text { of } \\
\text { Cases. }\end{array}$} & \multicolumn{2}{|c|}{ Sex. } & \multicolumn{2}{|c|}{$\begin{array}{l}\text { Aversge } \\
\text { Age. }\end{array}$} & \multicolumn{3}{|c|}{ Race. } & \multicolumn{2}{|c|}{$\begin{array}{l}\text { No. of } \\
\text { Deaths. }\end{array}$} & \multicolumn{2}{|c|}{$\begin{array}{c}\text { No. of } \\
\text { Recoveries. }\end{array}$} & \multirow{2}{*}{$\begin{array}{l}\text { Death. } \\
\text { rate. } \\
\text { Gross. }\end{array}$} & \multicolumn{2}{|c|}{$\begin{array}{l}\text { Death-rate } \\
\text { per cent. } \\
\text { of Attacks }\end{array}$} \\
\hline & M. & F. & M. & F. & White. & $\begin{array}{c}\text { Col- } \\
\text { oured. }\end{array}$ & Black. & M. & F. & M. & F. & & M. & F. \\
\hline 47 & 32 & 15 & $25 \cdot 9$ & $23 \cdot 46$ & 40 & 5 & 2 & 18 & 10 & 14 & 5 & $59 \cdot 57$ & $56 \cdot 2$ & $66 \cdot 3$ \\
\hline
\end{tabular}

More than twice as many males as females attacked, but percentage of deaths amongst females attacked was greater than amongst males. Ten of those attacked were natives of the West Indies, one was an indentured East Indian immigrant, the remainder had resided in the West Indies for periods varying from four days to thirteen years.

The Origin of the Outbreak.-It is exceedingly interesting to note that this epidemic partook of the usual character, namely, the "bolt from the blue" type. There was a distinct feeling amongst the medical profession that the origin of the disease might be miasmatic-that is, that there were local predisposing causes. In other words, that there was something in Trinidad which, apart from importation, could give rise to the disease. This is, as we have seen, the revival of the ancient and long-buried doctrine of local miasmatic origin. It is the invocation of the miraculous to explain an outbreak which, to my mind, has a perfectly rational and easy explanation. A glance at the map of Trinidad shows at once the proximity of Trinidad to Venezuela. 
The former is placed at the mouth of the Orinoco. There is, therefore, a large trade and intercourse with Venezuela, and there are many Venezuelans and relations of Venezuelans in Trinidad. Moreover, the latter place is peaceful and prosperous, while the former territory, until quite recently, was the reverse. There is, therefore, an inset of traffic from Venezuela to Trinidad. If we enquire what are the health conditions obtaining in Venezuela, we learn that they have been very bad-as bad as could be ; there has been practically no health administration. Yellow fever, it is reasonable to suppose, is endemic in that country, and systematic anti-yellow fever measures have never been undertaken. We learn from our consular representatives that yellow fever is practically always present in La Guayra and Caracas, and in 1907 there were epidemics at Ciudad Bolivar - a trading port on the Orinoco having a constant communication with Port of Spain. There were some forty to fifty reported cases in 1907 , and some 150 in 1908 . These of course only represent the cases of fever amongst the better-class people; in all probability the cases amongst the poor and very poor were never reported, and the epidemic might therefore have been a very large one. U.S. Consul Moffat, reporting to Washington, 11th May 1907, from La Guayra, stated: "Yellow fever and smallpox are at all time more or less prevalent here." Ciudad Bolivar is only forty-eight hours distant by steamer from Port of Spain. In 1909, forty-one ships arrived from Ciudad; they were all cattle-boats and regular traders, with one exception; they all brought passengers. Being for the 


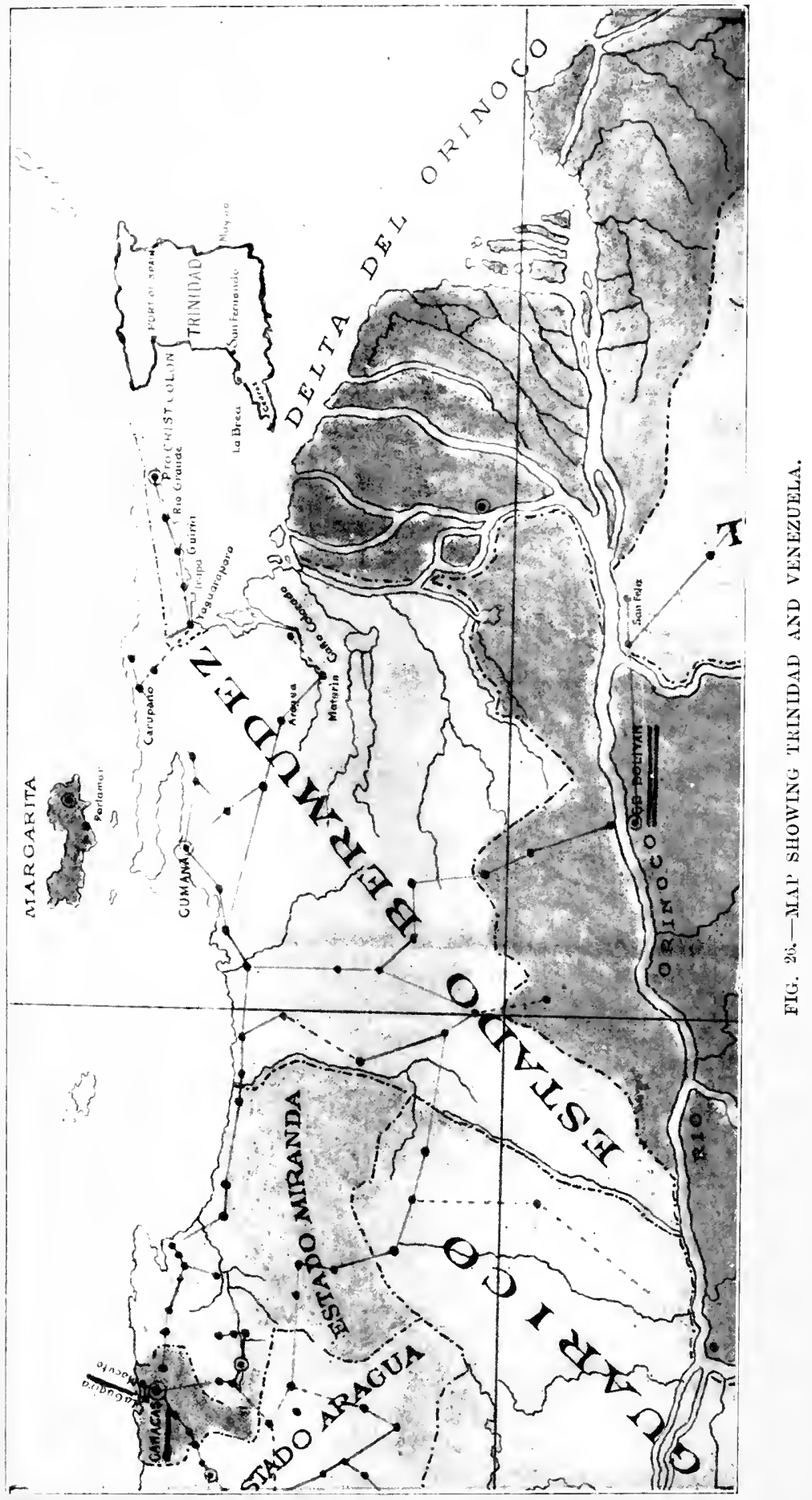



most part cattle-boats, they have to remain alongside the wharf at Ciudad for some time to load up. At all times, cattle-boats, unless under the strictest supervision, are a source of danger. Nevertheless, we learn that this form of craft was treated like all othersstrictly in accordance with quarantine regulations-and as the Venezuelan authorities no doubt rarely admitted under Castro's regime that they ever had yellow fever or plague, it is probable that these ships carried clean bills and were not fumigated at Port of Spain, nor the passengers and crew kept under observation in a quarantine station, or under surveillance. In my opinion, we do not want to invoke the long-buried tradition of miasms to account for infection, when there is such an obvious source as Venezuela, and one which has probably been ever present; and the reason why Trinidad has not been overrun with yellow fever and plague for years past, has been because, as we will show, the local sanitary organisation has been really excellent, and the Stegomyia has been kept under. Otherwise, I am convinced that yellow fever would be as endemic in Trinidad to-day as it is in Venezuela or in ports on the Amazon. As showing how Central American countries treat yellow fever and smallpox, the following statement is of interest :-

Report of the Prevalence of Yellow Fever in Central. America.

British Consulate, Guayaquil, Ecuador, November 10, 1906.

Sir,-I have the honour to report, in pursuance of instructions contained in Commercial Circular of the 
Foreign Office, No. 26350, dated 31st August last, that various cases of yellow fever exist at this port. There are ten cases under treatment in the Yellow Fever Lazarette, besides others in private houses (numbers not ascertainable). From 20th October last to date, four deaths have occurred from this fever.

Smallpox is also prevalent here on a large scale. The number of cases cannot be ascertained, but there have been eighteen deaths in the same period (since 20th October).

No measures whatever have been taken by the Government or municipal authorities to deal with these serious infectious maladies.

Alfred Cartwright.

The Colonial Secretary,

Trinidad.

In addition to Venezuela, Port of Spain has oversea relations with Brazil and the Amazon, Dutch Guiana, Central America, and Barbados.

To my mind, however, the evidence points to Venezuela, and in this connection I am informed by Dr Prada that in the 1894 epidemic in Trinidad the earliest cases were amongst Italians who had come from Venezuela, and that from them it rapidly spread.

As Venezuela is so close to British territory, and as it is the country which commerce-paralysing diseases are most likely to traverse, I have made special enquiry into the health conditions obtaining there, and SurgeonGeneral Clare has furnished me with the following useful information :-

Health Administration in Venezuela.-It will be understood that these observations were made in President Castro's time of office, and it is now to be 
hoped that with the change of Government, a sanitary awakening similar to that which has passed through Mexico and Brazil, will be brought about.

Notification of infectious diseases are not compulsory. The British Minister at Caracas says, under date 12th December 1907 :-

I have the honour to inform Your Excellency that a considerable amount of smallpox has continued to prevail at Caracas up to the present date. . . . In reply to Your Excellency's dispatch of the 3rd instant, which reaches me as I write, I would explain that the notification of infectious diseases is not compulsory in this country, and that, consequently, the authorities are not able, even were they anxious, to provide accurate information. In point of fact, their attitude is the reverse of helpful.

The British Vice-Consul at La Guayra says, under date 4th July 1907 :-

No sanitary report is furnished from the hospitals or by the doctor of the port. One is therefore obliged to depend merely on public rumours to learn when there is any increase in the sick rate of the town. . . . While on this subject, it might be well to state that although there is always some fever in La Guayra (and indeed all other ports of Venezuela) from which deaths do occur, it is not at all certain that it is yellow fever. It is only given that name in the rare cases in which foreigners are attacked, and the greater number of these cases even are not fatal.

July 4th, 1907.-The British Vice-Consul at La Guayra says :-

There is no means of obtaining any official or 
reliable information on the subject of the diseases existing, or about fresh cases which may occur.

The British Minister at Caracas reports, under date 7 th July 1908, while transmitting a copy of a note from the Minister of Foreign Affairs, Venezuela, stating that plague had been exterminated in the port of La Guayra :-

In spite of this official announcement, I am given to understand by the Vice-Consul at La Guayra that two more cases have occurred, the last on the 30th ultimo. These are no part of those I mentioned in my postscript in my last communication.

The Vice-Consul's report said :-

As regards this city, I hear that there were two cases on Sunday last. Certain perfunctory precautionary measures are being taken. ... I understand that the Government of Caracas imposes quarantine on arrivals from Puerto Cabello, on account of the prevalence of yellow fever in that port.

In a private communication H.B.M. Minister at Caracas says, under date 1st December 1908 :-

It may be remembered that yellow fever is more or less endemic in the Maracaibo district.

July 7th, 1908.---British Minister at Caracas reports that the Government of Curaçoa are quarantining arrivals from Puerto Cabello, on account of the prevalence of yellow fever in that port.

Under date, Guayra, 20th September 1908, the British Vice-Consul says :--

The sicknesses in Yaguarapero, Yrapa, and Cristobal 
Colon are endemic fevers; but I must inform Your Excellency that the ports of the Republic pertaining to my Consular District take no precautions whatsoever to prevent contagion, should there be any epidemic in other states of the Republic.

In reporting three authenticated cases of plague at Caracas, under date 5th June 1908, the British Minister says :-

No official communication of any kind has been made on the subject, and no information is obtainable from official sources. The Press, which is under Government control, has not alluded to the matter. No trains have as yet been permitted to run between Caracas and La Guayra, but carts are permitted to convey goods under certain restrictions. Clandestine communication is constant. The fund collected for prophylactic measures is exhausted and great discontent is prevalent in the town. A few days ago there were some incipient attempts at riot and the offices of the German firm of Blohm were stoned. . . . The information to be obtained from the sanitary authorities is demonstrably false.

Under date 4th May 1908, the British Minister says :--

No credence need be attached to the "official" figures given above. There is reason to believe that they might be doubled or trebled without exceeding the mark. The sanitary cordon, which is supposed to isolate La Guayra, continues to be a pure farce.

21st April 1908.-Reporting several more deaths from the mysterious sickness, which afterwards proved to be plague, the British Minister says :--- 
The Venezuelan Government has at last had recourse to other measures than the imprisonment of the doctors who reported it, and a Presidential Decree, dated 18th April, prohibits all communication with La Guayra for a period of fifteen days .... the difficulty of obtaining reliable information is very great. . . . I understand from the Vice-Consul at La Guayra that funerals are taking place secretly and at night . . . efforts adopted by the authorities are entirely directed by executive officers without expert medical or sanitary advice, and are likely to prove as inefficacious as they are drastic . . . the sanitary cordon is a farce. Fugitives from La Guayra can easily reach Caracas on foot by the mountain paths, and the number so arriving must be considerable.

These memoranda conclusively show that the sanitary organisation was in a very weak state, and that no reliance could be placed upon any health report issued from Venezuela. So obviously bad was the system of notification that the British Minister at Caracas sent a special memorandum on the subject to the Minister of Foreign Affairs in Venezuela, pointing out the great disadvantage of the system to commerce. In December 1908, Trinidad was asked to remove quarantine restrictions against arrivals from Venezuela. The Surgeon-General, in my opinion, replied correctly when he pointed out that as they had no really trustworthy information of the health conditions obtaining in Venezuela, it would be unwise to remove restrictions. The opinion of the Surgeon-General was not, however, followed, and quarantine restrictions were removed. This action, in my opinion, was most unwise. For until Venezuela puts its house in order, and the Trinidad sani- 
tary authority has positive evidence that there is an efficient sanitary administration, similar to that existing in Trinidad itself, it appears to me to be incumbent upon Trinidad to most carefully supervise all arrivals from Venezuela. I cannot too strongly insist upon the fact that plague is passing from the Pacific side of the American continent to the Atlantic side, and that one great highway for its passage is through Venezuela, where, owing to lack of organisation in the past, the conditions for its taking root and spreading are present. From Venezuela the plague is unquestionably creeping in its eastward course, and it has now got to its first barrier-that is, Trinidad; here, thanks to a very efficient medical organisation and sanitary service, it has been held in check. This, however, places a very severe strain on Trinidad, and in order to lessen it as much as possible, I strongly urge the careful inspection of all ships and passengers arriving from Venezuela.

In connection with a more stringent supervision of the Venezuelan traffic, Mr H. B. Walcott, Collector of Customs, Trinidad, suggested a line of action similar to that adopted with success in British Honduras-namely, the insistence of weekly reports from the Consuls in Venezuela, the examination of Venezuelan ports by English medical officers, as done in Guatemala and in Spanish Honduras, then systematic inspection and fumigation of all ressels arriving from Venezuela, as was done in Belize. La Guayra is the port for Caracas, and Ciudad Bolivar is the large port on the Orinoco. From both places steamships come, both to Port of Spain and San Fernando. Moreover, small sailing 
craft of from 5 to 10 tons, which ply an irregular trade, also pass between these ports. The smaller boats may come to La Brea and Mayaro.

On 17th May 1909, I visited the s.s. Delta, a stern-wheeler used in the cattle and passenger trade between ports on the Orinoco and Port of Spain. I examined the ship. I did not observe any mosquitos on board, but it would be very easy for mosquitos to gain access while she was moored alongside at Bolivar.

The following memorandum on the communication between Trinidad, Venezuela, and the Orinoco River has been kindly furnished me by the Collector of Customs, 10th May 1909.

The number of vessels entered and cleared from and to Venezuela and the Orinoco during the year ended 31st March 1908 was as follows :-

Entered.

Sailing vessels . 1,413, 18,052 tons.

Steamers . . 176, 124,258,
Cleared.

$1,457, \quad 18,377$ tons

$242,274,013$,

The stean communication is as under :-

Orinoco River (Bolivar, San Felix, and other points on the river) to Port of Spain. One steamer fortnightly, and occasional steamers. Time taken, thirty to thirtysix hours.

Venezuelan coast of Paria to Port of Spain. Occasional steamers, guarda costas, and launches. Time taken, six to thirty-six hour's.

Northern coast of Venezuela (Carupano and onwards) to Port of Spain. French Line, one monthly. Dutch Line, two monthly, Hamburg American Line, two monthly, and occasional steamers. Time taken, seven to ten hours. 
The communication by sailing vessels is :-

Venezuelan coast of Paria (usually Maturin) to Port of Spain. One ton upwards, average one a day. Time taken, three days.

Venezuelan coast of Paria, Bolivar, Maturin to San Fernando. One ton upwards, average one daily. Two to three days.

Orinoco to La Brea, Mayaro, and Cedros. Open corials. Time taken, three days. Nearest point northern coast of Venezuela, Christobal Colon, and other places to Monos. Open boats. Average, one daily. Time taken, six to twelve hours.

As I mentioned in my interim report to the Governor of Trinidad, in my opinion it would be most desirable that the whole services of a medical officer should be used for the duties of quarantine officer, and that he or an assistant medical officer should from time to time visit towns in Venezuela, so as to make a personal investigation of the health conditions obtaining there.

Diffculties of Diagnosis.-Just as difficulties over the question of diagnosis occurred in Barbados, and have occurred time and time again in the history of all yellow fever outbreaks, so in Trinidad there were difficulties; and these difficulties, as in the case of Barbados, led to suspicions on the part of adjacent sister colonies. It will be recollected that Barbados diagnosed a form of gastric influenza accompanied by black vomit--a disease which was, in all probability, yellow fever. In Trinidad some of the medical men and Surgeon-General Clare diagnosed a very severe form of malaria-a typhomalaria - of few days' duration, very fatal, and sometimes, so it is stated, accompanied by vomiting. It is 
now, of course, of very little use to speculate as to whether this typho-malaria was really malaria or yellow fever or not. I mention the circumstances here, in order to emphasize the necessity in all cases where there is a difficulty of diagnosis in respect to diseases which have important administrative consequences, of convening a small board of medical experts to act as a consultative body with the Surgeon-General. Wherever one goes in the West Indies, there is always evidence of doubtful diagnosis, and in consequence plenty of interinsular incredulity - far more intercolonial confidence is required to work the quarantine laws to their best advantage.

Yellow Fever Prophylaxis in Trinidad. - The SurgeonGeneral furnished me with the following interesting memoranda of the precautionary measures taken :-

Special powers were secured for the sanitary authority by regulations made by the Governor in Executive Council on 22nd March and 6th April 1907, enabling prompt action to be taken with a view to accurate diagnosis and efficient control of each case as it occurred, and to limit the spread of infection; these regulations were amended and consolidated on the 16 th January 1908, and very active measures directed towards improved sanitary conditions, and the extensive destruction of mosquitos were in operation during the prevalence of the disease; there can be no doubt these operations were successful in largely controlling the spread of yellow fever in the town, but so many apparently distinct and yet potentially active foci of infection presented themselves at intervals, that it became a matter of much difficulty to exert and to maintain a restricting influence upon the progress of the disease. In this connection the importance of individual efforts in co-operation with the sanitary authorities can scarcely 


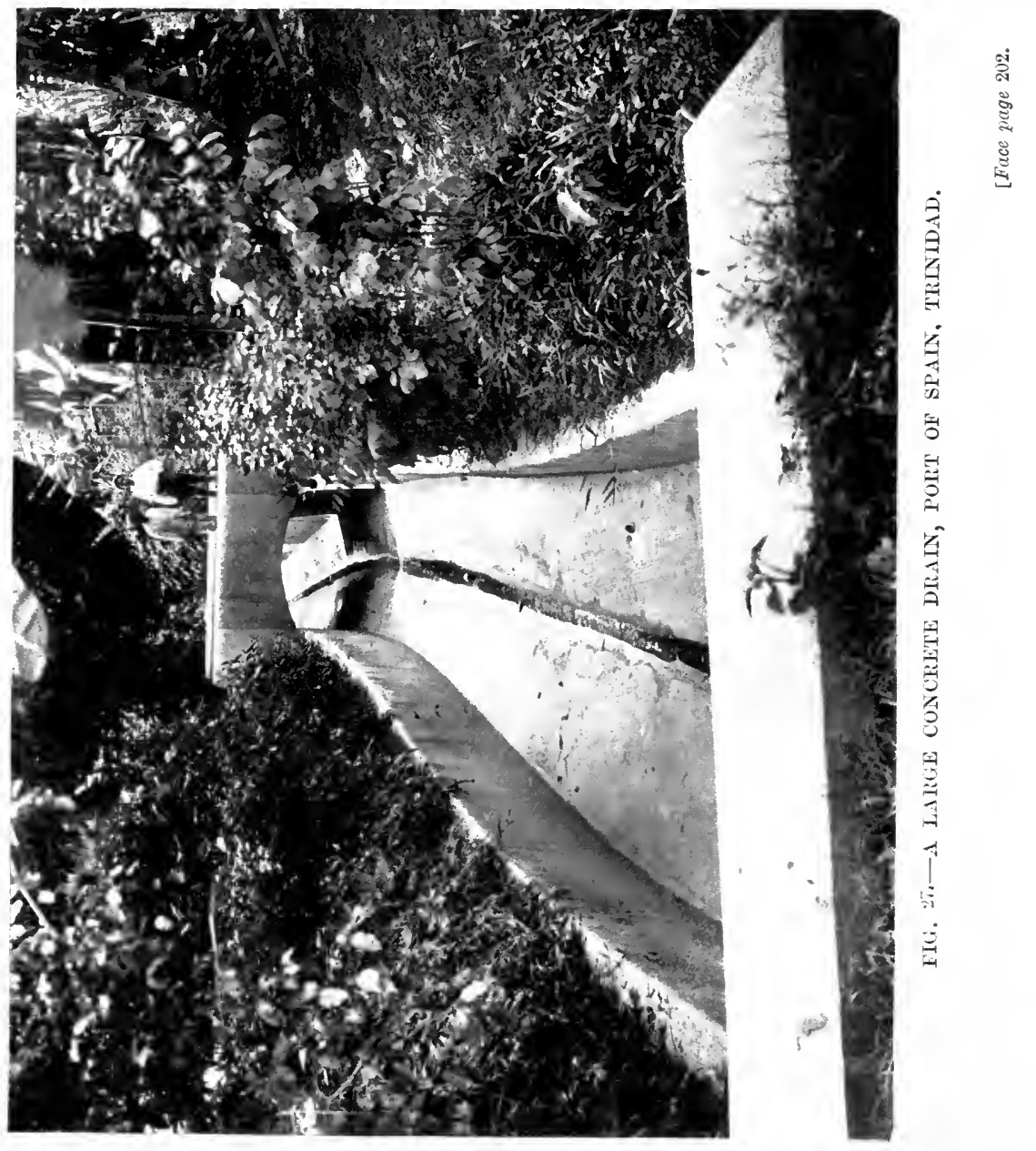



be over-estimated, and it is surprising, and a matter for regret, that persistent practical demonstrations and instruction by the sanitary staff appeared to arouse so little personal interest and sustained effort towards the protection of the individual and the community from extension of the disease.

On the occurrence of the first case, steps were at once taken for screening and isolating the patient, and for fumigating the house and the adjoining premises, and the residents in the immediate neighbourhood were kept under daily observation.

These measures were carried out generally with respect to subsequent cases.

The staff of assistant sanitary inspectors was augmented, for the more effectual inspecting and cleansing of yards throughout the town.

A proposal from the Acting Inspector-General of Constabulary for enlisting the services of the police in carrying out these duties was gladly accepted, and their co-operation proved of great assistance in the work of sanitation.

It was evident from the beginning of the epidemic that the infection was spread over a wide area in Port of Spain. No case, however, occurred near the waterfront, or in the lower half of the town.

It is to be regretted that it has not been found possible to arrive at any satisfactory conclusion with regard to the origin of the epidemic. Yellow fever is not endemic in Trinidad. It is remarkable that epidemics of the disease (although a difference of opinion obtained amongst medical men as to its nature) appear to have occurred at intervals of about twelve to thirteen years, viz. : in 1869, 1881-82, 1893-94, and in 1907.

Trinidad is peculiarly open to the importation of infectious disease from the neighbouring mainland of Venezuela, which presents a long coastline in close proximity, and there being no obligation on the part 
of the Venezuelan authorities to notify the existence of such infectious disease.

(Up to the end of June there have been twenty-four cases notified, with eleven deaths. Later cases were generally of a milder type. The fact that not more than one case occurred in any house, would afford ground for believing that the preventive measures adopted were effective.)

As evidence of the activity of the sanitary service and medical administration, I quote the following extract of the proceedings of the Board of Health, (published in the Port of Spain Gazette, 4th May 1909) :

The acting sanitary inspector reported that the regular and surprise visits had been paid during the month of April, and of 471 orders served, 351 were complied with. Three cases of typhoid fever had occurred. One at Regent's Lane, Belmont, had since been discharged from the colonial hospital, another was still under treatment at that institution, while the third case, from No. 48 Charlotte Street, had proved fatal. In each case the premises were disinfected and advice given as to the storage of water, etc., and the necessity of keeping water-closets and drains in a sanitary condition. The following premises were disinfected for pulmonary and tuberculous diseases :-No. 6 Regent Street, 23 Belle Eau Road, 20 Frederick Street, 36 Piccadily Street, 5 Baden Powell Street, 2 Rosslyn Lane, 46 Charlotte Street, 2 Brunton Lane, and 40 Marine Square. The number of shops inspected was 165. Twenty-three prosecutions were instituted, and convictions obtained in all save one, where the defendant was not found. Twenty-one were against occupiers for failing to keep their premises free from stagnant water liable to breed mosquitos. A fine of 


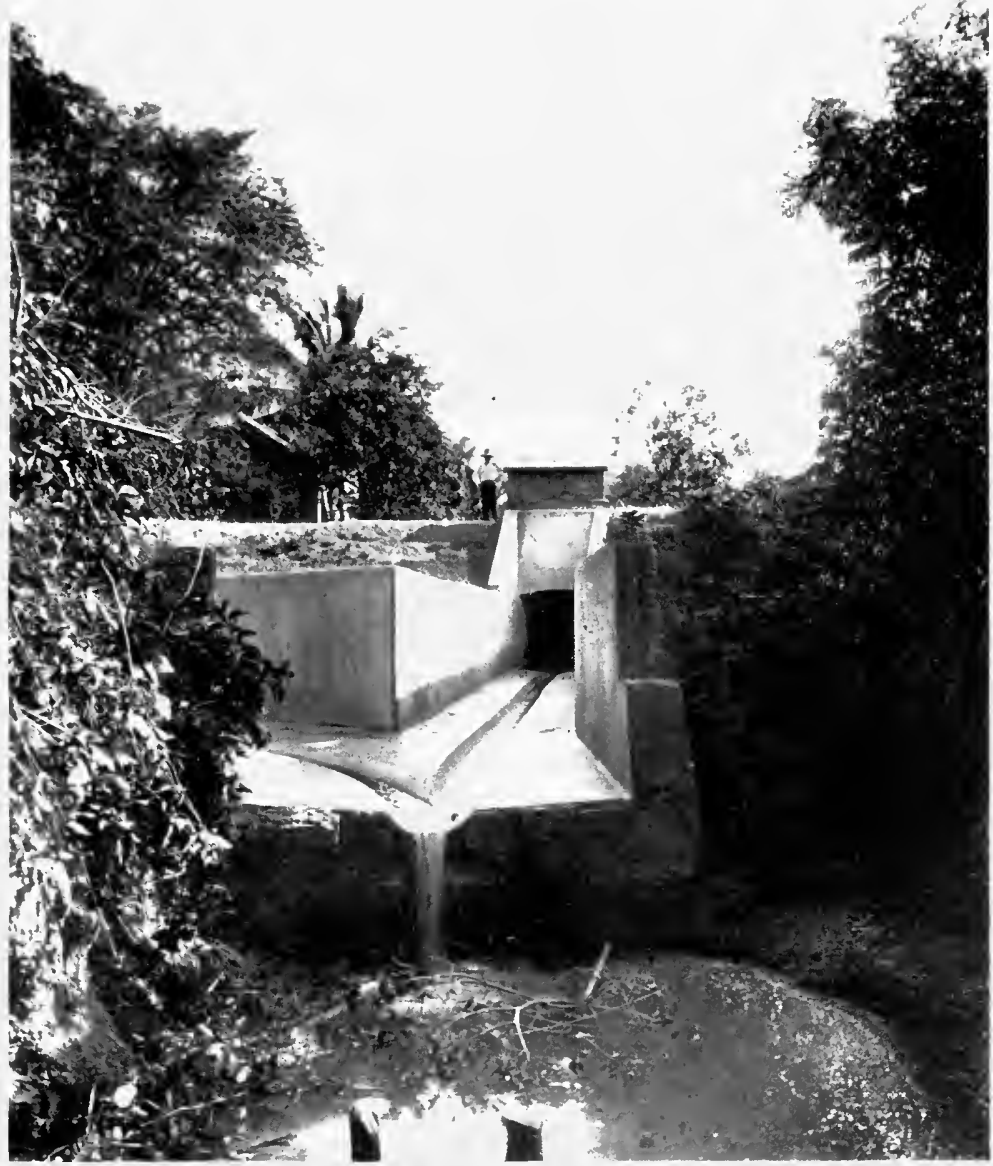

FIG. 28.- LARGE CONCRETE DRIINS, PURT OF SPAN, TIISIDAT). 

2s. 6 d. or 7 days' imprisonment was imposed in 20 cases, whilst one defendant, who was fined $£ 3$ or 14 days, elected to go to jail. In one case against an owner for not complying with an order served for the emptying and disinfecting of a cesspit, the defendant was fined £1 or 14 days' imprisonment. The fine was paid.

Trinidad is an example of what can be done by proper medical organisation and equipment. Considering that the total population of the island is over 300,000 , and that of Port of Spain over 70,000, the yellow fever outbreak of 1907-1908 has been a very small one.

The success of the present prophylactic measures should stimulate Trinidad to perfect its machinery still more; more especially because it has a volcano ever ready at hand in the form of Venezuela. The success which the medical authorities have had should also for ever banish the pessimistic and progress-destroying doctrine of miasm.

Stegomyia Survey.-If the enquirer wishes to understand why yellow fever and plague have not taken root in Port of Spain, let him do as I did, and make a detailed examination of the yards and houses in the various sections of the town. Altogether, I visited 211 lots in the poorest, middle-class, and better-class quarters in the town. I found the yards on the whole clean and free from odds and ends, and in many cases concreted. I was glad to note a great absence of bush in the yards; there was nothing to impede the sun's rays nor the fresh air. I also noticed a useful innovation in the fact that the down-spouts of many of the 
roof-gutters were conducted directly over the yard drain, thus preventing placing a barrel under it; in some cases indeed there were no roof-gutters at all, in order to preclude the possibility of water lodging there, as it so often does. In the 211 lots I examined, for larvæ,-

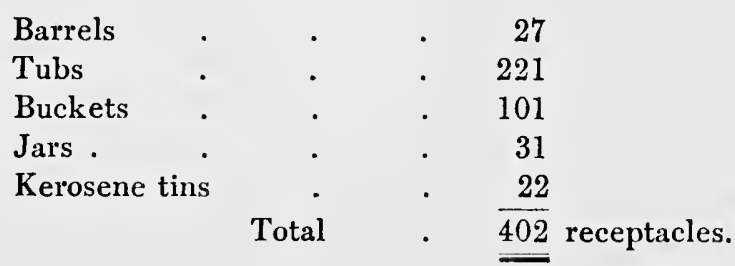

Larvæ were found in 24 out of the 211 lots.

The first striking fact is the small number of barrels. Of all the towns which I have visited, Port of Spain contains the smallest number relatively, and no doubt this is the reason why the Stegomyia larvæ were also scarce. It will be noted that there is a large quantity of tubs; these I found usually exceedingly clean; they are used for washing only. In the majority of yards there were water-taps, and, as I have mentioned above, the down rain-water spouts were turned directly over the drains without the intervention of a barrel. On these tours of inspection I was accompanied each morning by Surgeon-General Clare and Dr C. F. Lassalle, the chief sanitary inspector, and, later on in the month, by Dr J. R. Dickson, who had returned from leave of absence. In my opinion, they all deserve unstinted praise for the excellent condition of the yards. The sanitary authority is indeed fortunate in having as its two chief sanitary inspectors such highly qualified medical 
men as Dr's Lassalle and Dickson. Whilst in Port of Spain the ordinary receptacles for breeding mosquito larvæ are few, it is worthy of note that the taste of the inhabitants for flower cultivation has introduced a special water-container which does tend to encourage the breeding of mosquito larvæ-these are known as antiformicas.

Antiformicas are various forms of water receptacles used for the prevention of umbrella ants reaching flowers. They are made either in the form of metal or earthenware rings or collars, which surround each plant, and capable of holding water, or as a cement drain running round a flower-bed. They are all liable to breed mosquitos, because the water may be left too long in them.

\section{Malaria in Trinidad.}

General Mortality and Malaria Rates in Port of Spain.

\begin{tabular}{|c|c|c|c|c|}
\hline Year. & Deaths. & Death-rate. & $\begin{array}{c}\text { Deaths from } \\
\text { Malaria. }\end{array}$ & $\begin{array}{c}\text { Rate per } \\
1000 .\end{array}$ \\
\hline $1904-1905$ & 1638 & $27 \cdot 76$ & 32 & 0.54 \\
$1905-1906$ & 1949 & $32 \cdot 48$ & 74 & $1 \cdot 23$ \\
$1906-1907$ & 1909 & $31 \cdot 81$ & 78 & $1 \cdot 03$ \\
$1907-1908$ & 1838 & $30 \cdot 63$ & 71 & $1 \cdot 18$ \\
\hline
\end{tabular}

Dr E. Prada, secretary of the medical board, Trinidad, informs me that blackwater fever is uncommonly prevalent in the adjacent island of Tobago; in fact, that it is the disease of Tobago, and attacks all new arrivals, people from the neighbouring island of Trinidad being liable to it; yet in Trinidad itself blackwater fever is rare. Another interesting fact is 
that in Trinidad, just as in British Guiana, the Barbadian labourers are very liable to malaria.

Mosquito Survey of Trinidad and Entomological Researches.-Mr F. W. Urich, Government entomologist, is doing excellent work in making a complete survey of the mosquitos of the island of Trinidad, and co-operating with the medical authority and the educational authority in pointing out the breeding places of the harmful mosquitos. He has prepared a series of documents and photographs showing the dangerous species and where they breed, and also the simple means which may be taken to prevent their breeding. He has also prepared a card pointing out the fish which eat mosquito larvæ. In this respect his educational work is more up to date than anything I have seen as yet. Mr Urich mentions several species of predatory larvæ which attack mosquito larvæ, and has furnished me with specimens.

I visited, on 10th May, some special breeding grounds of mosquitos with $\mathrm{Dr}$ Clare and $\mathrm{Mr}$ F. W. Urich. The latter demonstrated the work he was doing upon the breeding places of mosquitos. $\mathrm{He}$ divides the tree and plant breeding places into three groups-namely, the "rot-hole," the "bromelia," and the "bamboo." In an examination of five trees, we found larvæ present in the rot-holes in three of them. They were readily syphoned out with a pipette. A considerable number of the species were predatory. $\mathrm{Mr}$ Urich is describing a bromelia Anopheline, which he thinks may be a source of malaria upon the cocoa and other plantations. I also visited the Caroni swamp 


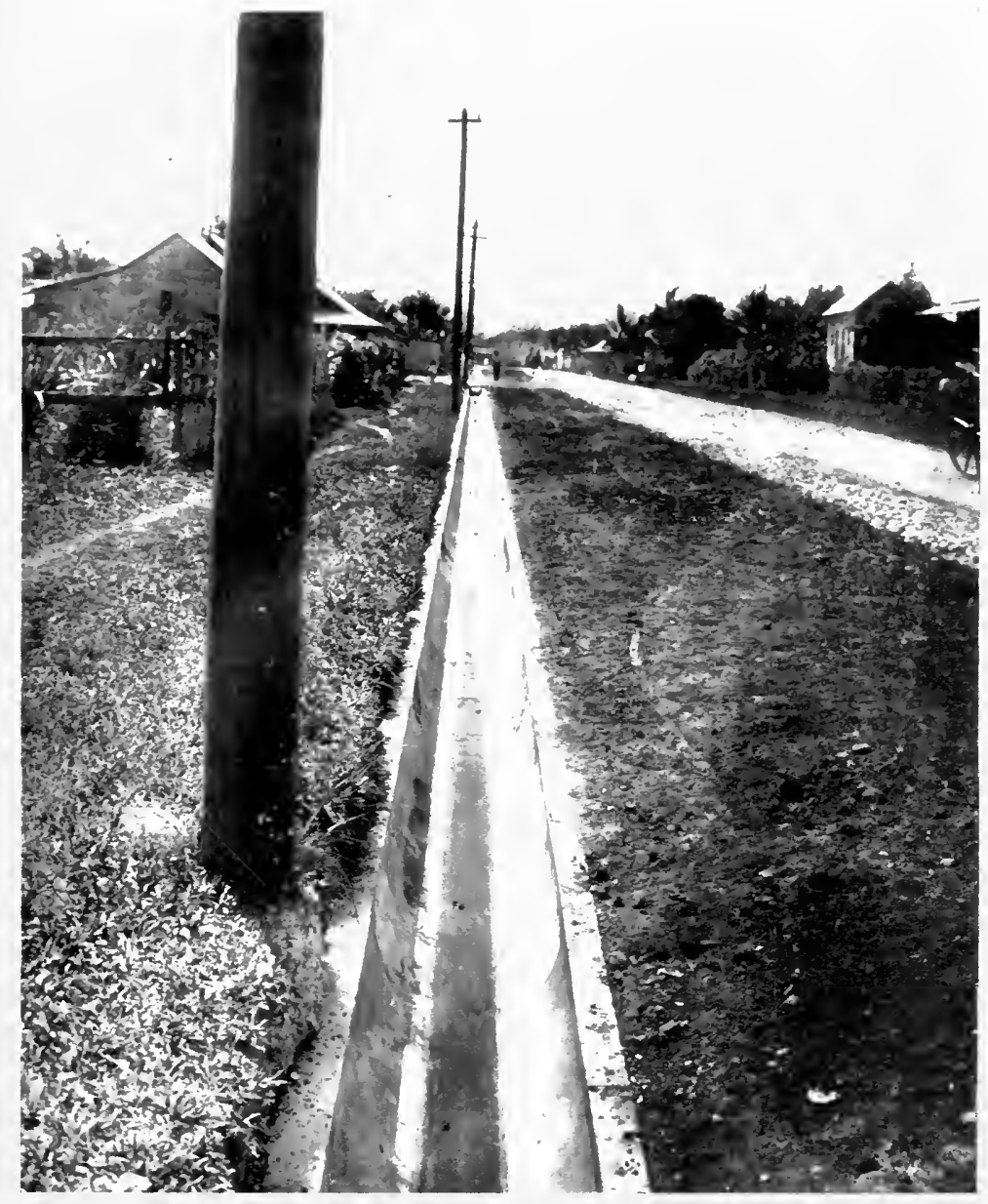

FIR, 29.-1 COXCRETE IOAINIDE DRAIN, POHT OF SPAIN, TRINIDAD, 

and saw breeding places of Anophelines. This district has a bad reputation for malaria. The breeding places are the small pools, as the larger channels are stocked with fish. The district ought to be well drained.

List of Anophelines in Trinidad (on the authority of Mr Urich) :-

1. Anopheles tarsimacula, Goeldi . . Grassy pools. $A$. argyrotarsis and $A$. albimanus.

2. A. mediopunctatus, Theo . Cycloleppteron (m.).

3. A. bellator, D. and K. . . . Bromelia. A. lutzii.

4. A. maculipes, Theo . . . . Grassy pools. Arribalzagia maculipes.

5. A. apimacula, D. and $\mathrm{K}$. Proc. Biological Soc. of Washington, vol. xix., p. 136.

"Generally speaking, Anopheles tarsimacula, Goeldi (Syn. A. argyrotarsis or albimanus), is the common species on lowlands, especially in badly-drained districts near swamps, generally occurring on the coast. Associated with it are to be found $A$. maculipes, Theo, and rarely $A$. mediopunctatus, $A$. bellator, $\mathrm{D}$. and $\mathrm{K}$. A species closely allied to $A$. lutzii, Theo, is a forestinhabiting species living only in Bromeliæ. It is found in hills where there is no water. It is also found on cocoa estates, where Bromeliæ are allowed to thrive in abundance on the shade trees. Common in forest all over the island and on many cocoa estates. My attention has often been called to the fact by country people that fever is prevalent in recently felled land: I put it down to this species and not to A. tarsimacula. Dr Dickson 
has promised to find out whether it is a malaria carrier or not." Dr Lassalle also in 1903 made a collection of the principal mosquitos of Trinidad. The description of these is published in the 1902-3 Annual Report of the Surgeon-General.

In addition to Drs Urich and Lassalle, Trinidad is also fortunate in having a volunteer in Mr Caracciolo. In fact, the entomological equipment of Trinidad is exceedingly good and is bearing excellent fruit.

There has been a co-operation between the agricultural and scientific departments under the leadership of Lieutenant-Colonel Collens, Professor Carmody, and the Acting Superintendent of the Botanic Gardens, Mr Evans, the practical result of which has been that since 1905, systematic instruction has been given in insect pests to pupil teachers and others, and still more recently the system has been further strengthened by co-operation with the medical authority, so that sanitary inspectors are now being trained by the Surgeon-General's officers, Doctors Dickson and Lassalle, and Mr F. W. Urich. In my opinion, this colony is one of the most advanced in this respect, and, having made such a good start, I now suggest that a bacteriological and medical entomological department be established as soon as possible, so as to reap at once the advantages which must accrue. The usefulness of such a department to the colony cannot be over-estimated: it would assist the medical profession and agriculture. It is a most happy coincidence that Trinidad at the present moment possesses a group of admittedly kcen investigators second to none. If this 
scientific department were established and regular transactions published, the gain to tropical medicine, and to the advancement of health and commerce would be very great.

Sanitary Science Training.-In reply to a communication addressed to the Government of Trinidad by the then Secretary of State for the Colonies ( $\mathrm{Mr}$ Alfred Lyttleton), dated 20th May 1904, both the SurgeonGeneral and the Director of Education described the steps which were being taken to teach elementary tropical hygiene in the schools. They both sympathised with the necessity for this teaching, and since that date much has been done by the Director of Education, Surgeon-General Clare, Dr Dickson, and Mr F. W. Urich; indeed their work in this respect is admirable, and might with advantage be followed in other colonies.

Annual reports are published by the Government analyst, Professor Carmody, containing much useful information upon subjects relating to public health.

On the training given to sanitary inspectors, SurgeonGeneral Clare writes me as follows :-

The small elementary book published by $\mathrm{Dr}$ Dickson on Hygiene, forms the basis of the instruction given in a course of lectures extending over three months to candidates training to become assistant sanitary inspectors; the third course is now in progress.

Dr Dickson's notes have been re-edited and further developed and extended, and a second edition is now in the printer's hands, and will shortly be published. Dr Dickson's work is one of the text-books which I 
recommended for the use of elementary school teachers, for whom I suggested that courses of lectures on hygiene should be arranged and that hygiene should be made a subject for teachers' certificate examinations.

Elementary Instruction in Hygiene.-The Director of Education, Lieutenant-Colonel Collens, has inaugurated a very admirable system of elementary instruction in hygiene, especially in relationship to mosquito-borne diseases, and for this purpose various pamphlets have been drawn up, two by Dr Dickson, one of an elementary but very practical kind, and the other of a more detailed description. These two pamphlets, together with Prout's pamphlet on Hygiene, are extensively used throughout the colony in the schools, and there is no doubt that this educational hygienic campaign is bearing fruit, and that it should be copied in all other colonies. It appears to me to be the first serious attempt at teaching tropical hygiene in schools. In addition, a systematic series of lectures in hygiene and hygienic instruction generally is given to candidates wishing to become sanitary inspectors in the town or Port of Spain. These demonstrations are given by Drs Dickson and Lassalle. In this way it is hoped to procure for the town of Port of Spain a corps of well-trained sanitary inspectors.

To show that this system is put into practice, I insert the following notice from the Port of Spain Gazette of 9th May 1909 :-

At 8.55 o'clock yesterday morning, Dr C. F. 


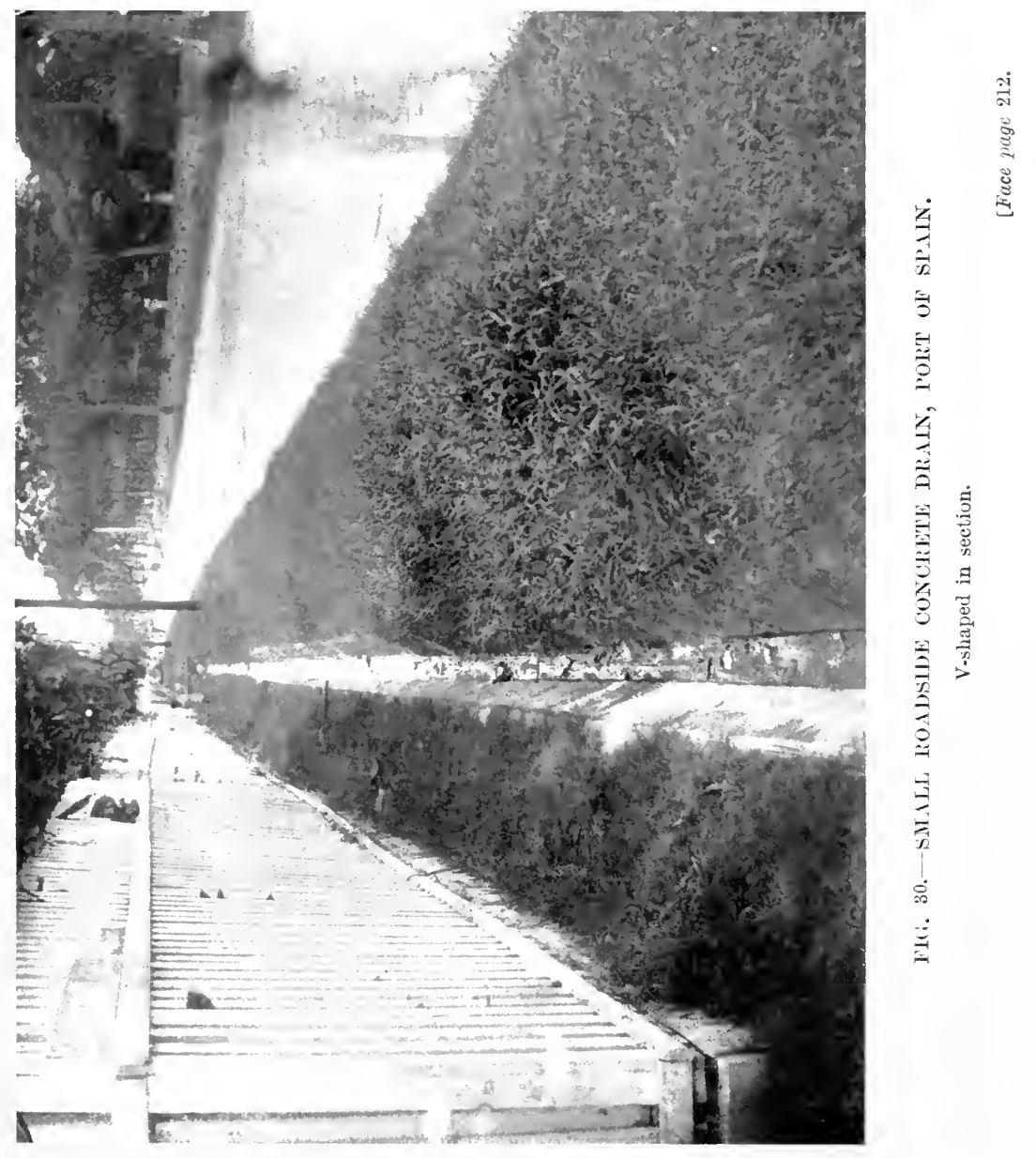



Lassalle, D.P.H., continued his lecture on hygiene at the Victoria Institute, before a number of the constabulary and elementary teachers. The number of the latter has increased by five. The lecturer reviewed the nervous, the circulatory, and the alimentary systems of the human body.

To illustrate the earnestness of the educational movement in Trinidad, I insert here for the guidance of other colonies the following report upon education which has been furnished me by Colonel Collens, the inspector of schools.

Report on the Teaching of Hygiene in Trinidad and Tobago.

A course of weekly lectures on hygiene and sanitation, lasting for a term and ending with a test examination, has been given this year at the Victoria Institute by Dr Dickson, Assistant Medical Officer of Health. Though intended mainly for assistant sanitary inspectors and candidates for similar posts, it was also open to primary school teachers, and, as the lectures were given at a convenient hour on Saturdays, several schoolmasters took advantage of the opportunity thus afforded them.

As a further step towards the teaching of hygiene in our schools, it has been placed by the Board of Education upon the syllabus of the Teachers' Certificate Examination, and will consequently form one of the optional subjects in the next annual examination, to be held in April 1909. The text-books specially recommended for study are Dr Prout's Elementary Hygiene and Sanitation, and Dr Dickson's Lecture Notes on Elementary Hyyiene. There has been such a demand for the latter, that the first impression is exhausted ; but a new and revised edition is in the hands of the printer, and will shortly be ready for issue. 
Mr F. W. Urich, F.E.S., of the Education Department, has prepared one or two lantern slides, illustrating the life history of the mosquito, and has been successful in obtaining some good negatives, from which he can add to the number.

In many schools hygiene is often taken at the annual examination as the subject for object-lessons, particular stress being laid upon the part insects play in the spread of malaria and other diseases.

I have now brought forward sufficient proof to show the earnest nature of the educational movement in Trinidad, and it is with still greater pleasure that I can myself testify to the support which both the Roman Catholic and the Protestant clergy give to this beneficent and humanitarian movement.

Sanitary Administration.-The ordinances 187 and 188 form the two Health Acts, and in addition to these there are several special ordinances relating to food and drugs, to lepers and yaws, to the registration of births and deaths, to vaccination, to bakehouses, to water, sewers, the medical board, etc. A new ordinance has been drafted in 1909, relating to public health, and in it the sanitary authority has inserted clauses which relate to larval and mosquito destruction, in connection with yellow fever and other insect-borne diseases. It is in these respects, therefore, fully up to date.

The General Board of Health. - The constitution of the General Board of Health is regulated by section 3 of Ordinance 187-its powers are purely advisory, and it is not entrusted with any funds; the members at present are :- 
The Governor, President.

Hon. Surgeon-General, Chairman in Governor's absence.

The Mayor of San Fernando. ex-officio.

Chief Commissioner, Port of Spain.

$\left.\begin{array}{l}\text { Dr H. M. Alston. } \\ \text { Dr S. Lawrence. }\end{array}\right\}$ Nominated by Medical Board.

Hon. Protector of Immigrants.

„ Attorney-General.

" Director of Public Works.

„ Inspector-General of Constabulary.

The Director of Agriculture.

The Crown Solicitor.

Dr R. H. E. Knaggs.

Dr J. W. Eakin.

Dr E. I. Read.

Dr E. Prada.

Mr A. D. Owen.

The Surgeon-General is also Chief Medical Officer of Health for the Colony; and there is an Assistant Medical Officer of Health, who is also sanitary inspector for Port of Spain under the Surgeon-General's direction.

Port of Spain has also a Town Board of its own, which consists of eleven householder's nominated by the Governor, who also appoints one of them to be Chief Commissioner with salary fixed by Legislative Council. This board discharges all the functions of the late Town Commissioners, the Water Authority, and the Sewerage Board, and exercises control over water-supply, sewerage, drainage, etc., of the town: the Surgeon-General and Chief Medical Officer of Health for the colony has no jurisdiction in these matters in Port of Spain.

In the country districts the Warden is the sanitary inspector and the executive officer in charge of the general sanitation of his ward-in some wards he has 
assistant sanitary inspectors, who are also his ward officers-many of these officers are devoid of any training in sanitary matters.

The Port of Spain Town Board has no medical officer of its own, as in the case of Georgetown, Demerara, nor has it a Town Supervisor. It employs, however, a Chief Engineer (Mr E. V. Acton). Therefore the Surgeon-General is the official medical head, not only of the colony, but also of the town of Port of Spain, and he has under him an assistant medical officer of health, who is called Sanitary Inspector of Port of Spain. This is Dr Dickson, and the arrangement seems to work admirably. Thus Dr Clare has power to see that the sanitary arrangements of the houses in Port of Spain are kept up to the proper standard, and it is he who initiates antilarval or other special measures. $\mathrm{He}$ has, however, no jurisdiction over drainage, sewerage, or water-supply. These are functions that are taken over by the Port of Spain Town Board.

In other colonies in the West Indies the medical officer for the town may not be under the direct control of the Surgeon-General. On the other hand, in Port of Spain the chief sanitary officer is practically the medical officer of health of the town, and is the assistant of Dr Clare.

Sanitary Staff of the Port of Spain.

Surgeon-General and Chief Medical Officer of Health of the Colony.

Assistant Medical Officer of Health, who is also the Chief Sanitary Inspector of Port of Spain.

Five Assistant Sanitary Inspectors. 


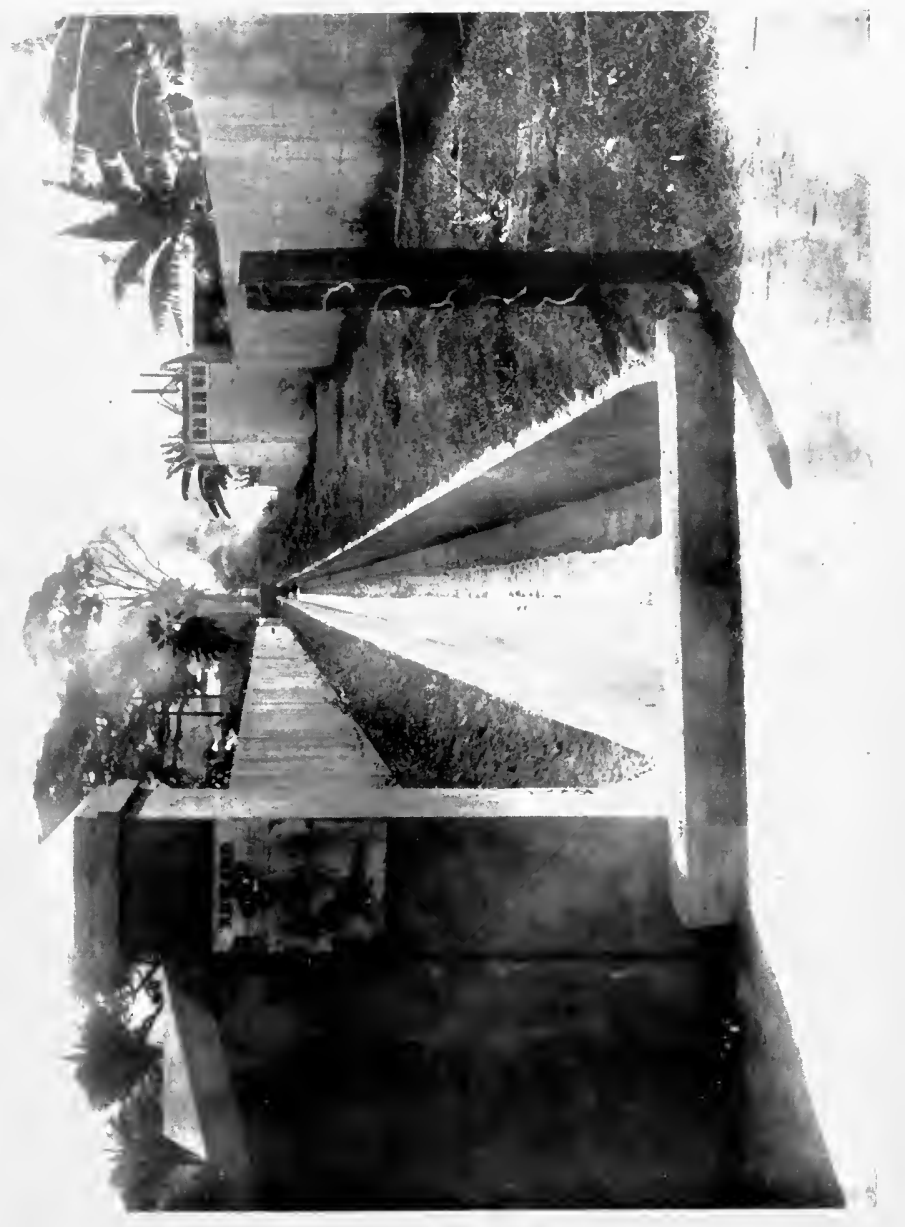

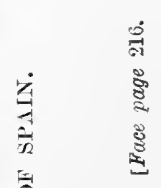



Eight extra Assistant Sanitary Inspectors.

Eight cleansing gangs of three men, each under a headman.

One headman at Belmont.

Two boys for handling rats.

One clerk for recording rats, paying for rats, etc.

One man for disinfecting and spraying premises, railway carriages, etc.

Note. - Eight extra Assistant Sanitary Inspectors and eight cleansing gangs employed since outbreak of plague.

One headman at Belmont specially employed in Antimosquito work.

\section{Assistant Sanitary Inspectors:-}

One is engaged in clerical work, keeping of books and records, preparing of returns, and assisting the Sanitary Inspector generally in office work.

The town is divided into twelve districts, one of which is allotted to each of the other twelve Assistant Sanitary Inspectors.

\section{Districts of Assistant Sanitary Inspectors:-}

Mr Thorne.-Duncan Street, Nelson Street, George Street, Charlotte Street, and all cross streets from the river to Henry Street, from Park Street to the sea.

Mr Mark.-Henry Street, Pembroke Street, Chacon Street, and all cross streets fron Henry to Abercromby Street (south of Park Street).

Mr Huggins.-Abercromby Street, St Vincent Street, Edward Street, part of Sackville Street, and cross streets from Abercromby to Richmond (south of Park Street).

Mr Rawlins._Richmond Street, Sackville Street (from Richmond Street to the sea), Francis Street, Charles Street, London Street, Kew Place, Fraser Street, Philip Street, Victoria Square, Scott Bushe Street.

Mr C. Herbert.-From Abercromby Street (north of Park Street) to Charlotte Street up to Queen's Park East.

Mr Sylvester.-From Abercromby Street to Victoria Avenue (north of Park Street).

Mr Parkinson.-Victoria Avenue to St Clair Avenue.

Mr Henly.-Woodbrook District.

Mr Henry.-Rose Hill District. 
Mr Roach.-From Clifton Hill to South Quay, including Plaisance Road and Picton Road (east of Dry River). .

Mr R. Herbert.-Belmont District up to Belle Eau Road.

Mr Smith.-From Belle Eau Road to Park Street East.

\section{Cost.-Month of April.}

Five Assistant Sanitary Inspectors ( $£ 75$ to $£ 100$ per annum each)

Eight extra Assistant Sanitary Inspectors (4s. 2d. per working day), and Rat Recording Clerk (2s. 11d. per day) . .

Eight gangs of three men each, and two boys for rat handling • $\cdot$ ·

One man for disinfecting and spraying premises, railway carriages, etc. (2s. per day)

$£ 38 \quad 15 \quad 0$

$\begin{array}{lll}49 & 17 & 6\end{array}$

$\begin{array}{lll}60 & 9 & 9 \frac{1}{2}\end{array}$

From the preceding account, it will be seen that Trinidad is fortunate in possessing an excellent sanitary organisation, and it is therefore not surprising to find how excellent have been the public works carried out under the various departments, including drainage and road-construction. The accompanying illustrations are proof of the excellence of the roads and the side drains, as well as of the large storm-water drains which have been made to take the bed of former small gullies and so avoiding thereby the formation of pools. These drains are splendid examples of their kind, and can well serve for models for tropical towns; they are a potent factor in preventing malaria. In Port of Spain there is everywhere evidence of concrete. The surfaces of very many of the yards are concreted, and as this has been done in the crowded quarters of the town, it has in a 
great measure contributed to diminish both rats and fleas, and therefore to lessen the dangers from plague.

The yards are kept clean and the roadways are as free from puddles as in any well-administered town in England.

Health Conditions upon Estates-Malaria and Ankylostomiasis.-I visited three of the sugar estates of Trinidad - namely, Orange Grove, that of the Usine St Madeleine, and Caroni. The impression which I obtained was that ranges or barracks were clean and well-ventilated, and that the labourers and their families appeared contented and happy. They have schools and hospitals of their own upon the estates. Rain or riverwater is used for drinking purposes. I did not see any screened water-barrels, but on the other hand, on one estate no larvæ were to be found in the barrels, as they each one of them contained a fish. The latrine accommodation was indifferent. Both water-supply and sewage disposal leave plenty of room for improvement, and obviously the expenditure is well worth the consideration of the estate managers and the Government. In his Annual Report to the Protector of Emigrants, the Surgeon-General states:-

I forward herewith the usual statistical returns for the financial year ended 31st March 1908, as required from me by section 233 of the Immigration Ordinance.

The total indentured immigration population dealt with by the medical risitors in the year under review was 10,929 , of whom 9266 were distributed on sugar estates and 1663 on cocoa estates.

The total number of cases treated within the year was 28,572 ; of these 26,039 occurred on sugar estates 
and 2533 on cocoa estates. 262 deaths are recorded on sugar estates and 19 deaths on cocoa estates yielding for their total populations respectively, percentage rates of 2.8 and $1 \cdot 14$, and a gross mortality rate of 2.56 on the total population.

"The incidence of sickness amongst indentured immigrants on sugar estates as compared with cocoa estates appears to be nearly twice as great, the records yielding 281 and 152.3 respectively, with a corresponding variation of the mortality rates: this very marked contrast may be due to the more arduous and exhausting labour conditions on sugar estates, but I think it is also referable in no small degree to the much greater prevalence of malarial diseases on sugar estates; indeed, the 'Principal Diseases Treated' nearly all present themselves relatively in much larger numbers on sugar estates than on cocoa plantations."

"Malarial fevers are responsible for more than a third ( 35.8 per cent.) of the gross tale of sickness amongst indentured immigrants, and the groups of estates in the two Naparima districts contribute nearly one-half of the total number of these cases; on these estates also, nearly half of the total cases of sickness of immigrants is attributed to affections of malarial origin, and in other districts perseverance in Chaguanas, Sevilla, Exchange, and Waterloo in Couva, and Esperanza in Pointe-ì-Pitre, exhibit in their case-books a large incidence of this fertile and preventable source of illness and diminished labour supply."

It is worthy of note that whilst blackwater is not recorded in Trinidad, yet it is often met with in the adjacent island of Tobago; thus four cases were reported in the year 1902-3.

Ankylostomiasis.-With regard to this disease, the Surgeon-General states: "Until greater precision in diagnosis and accuracy of record are obtained, the 


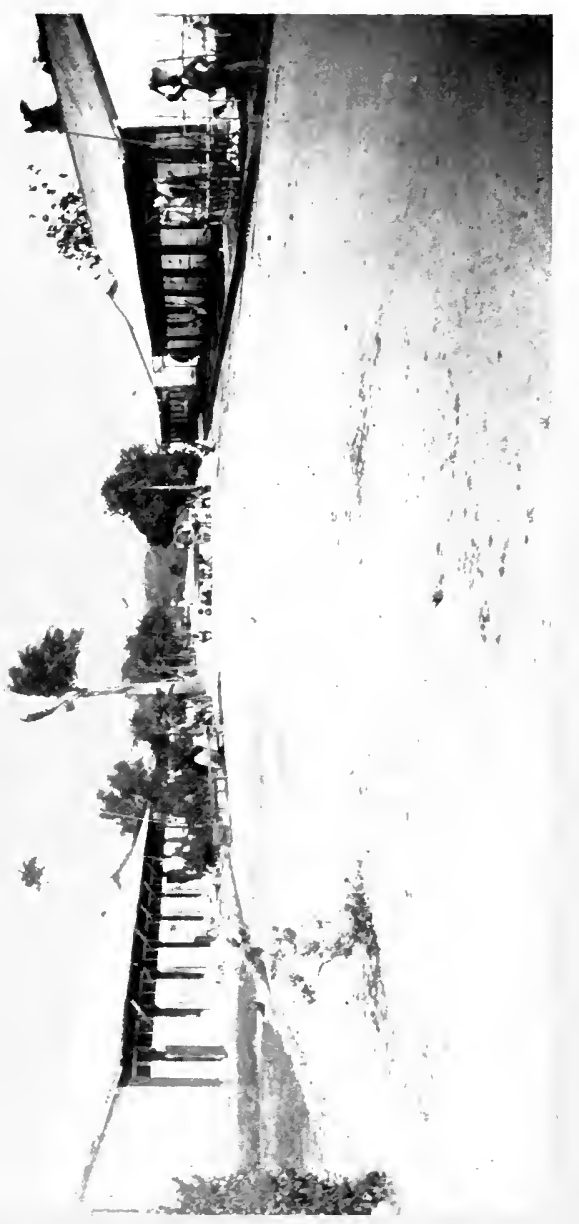

竞

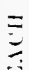

$-$

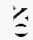

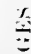

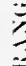

$\Xi$

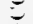

$\stackrel{1}{\vdots}$

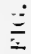



statistical returns under this as well as other headings must be unreliable, and the difficulty of devising and introducing measures for the control of disease must be correspondingly increased, as accurate information about the prevalence and distribution of any particular disease forms one of the essential factors on which to base operations for its prevention."

Return of Cases of Ankylostomiasis treated at medical Institutions and Estates during the years 1904-5, 1905-6, 1906-7, and 1907-8.

\begin{tabular}{|c|c|c|c|c|}
\hline \multirow[t]{2}{*}{ Period. } & \multirow{2}{*}{$\begin{array}{c}\text { Medical } \\
\text { Institutions. }\end{array}$} & \multicolumn{2}{|c|}{ Estate Hospitals. } & \multirow[t]{2}{*}{ Total. } \\
\hline & & Sugar. & Cocos. & \\
\hline $\begin{array}{l}1904-1905 \\
1905-1906 \\
1906-1907 \\
1907-1908\end{array}$ & $\begin{array}{l}216 \\
356 \\
427 \\
430\end{array}$ & $\begin{array}{l}158 \\
711 \\
107 \\
114\end{array}$ & $\begin{array}{r}17 \\
24 \\
5 \\
7\end{array}$ & $\begin{array}{r}391 \\
1091 \\
539 \\
551\end{array}$ \\
\hline Total . & 1429 & 1090 & 53 & 2572 \\
\hline
\end{tabular}

In the Surgeon-General's annual returns, ankylostomiasis receives a full measure of attention, as the following extracts show :-

\section{ANKYlostomiasis, 1905-6.}

"This disease has continued to be very prevalent, more especially among the immigrant labourers on the estates, and is, I fear, on the increase. There is no doubt that the extensive prevalence of the disease among the labouring class is a matter of very serious importance, as it is probably directly or indirectly the most potent cause of inefficiency, and it is of the highest importance that such measures as may be possible for the prevention and cure of the disease should be generally adopted. 
"With regard to the indentured immigrants, the following measures should be carried out:-

1. Periodical individual inspection and examination.

2. Prompt treatment of those affected.

3. The compulsory use of latrines.

4. The proper disposal of the excreta.

5. The smearing of the feet and ankles of the labourers with coal-tar before going to work in the fields.

6. The provision of a supply of pure drinkingwater.

"With regard to the general population, the want of control, and the fact that many people in apparent health act as hosts of the parasite and are sources of contagion, make it difficult to recommend practical measures for dealing efficiently with the disease."

\section{Ankylostomiasis, 1906-7.}

"Ankylostomiasis continues to prevail extensively, chiefly among the Indian population, and is a serious cause of disability amongst the labourer's on the estates."

"I have taken steps to carry out as far as practicable the measures specified in my last annual report for controlling, and if possible stamping out, this disease."

"Circulars were issued to all district medical officers, directing :

1. The systematic examination of all indentured immigrants, and the treating of all found infected;

2. The forwarding of a monthly return of cases; and the protector of immigrants was requested to impress upon the managers of estates the importance 


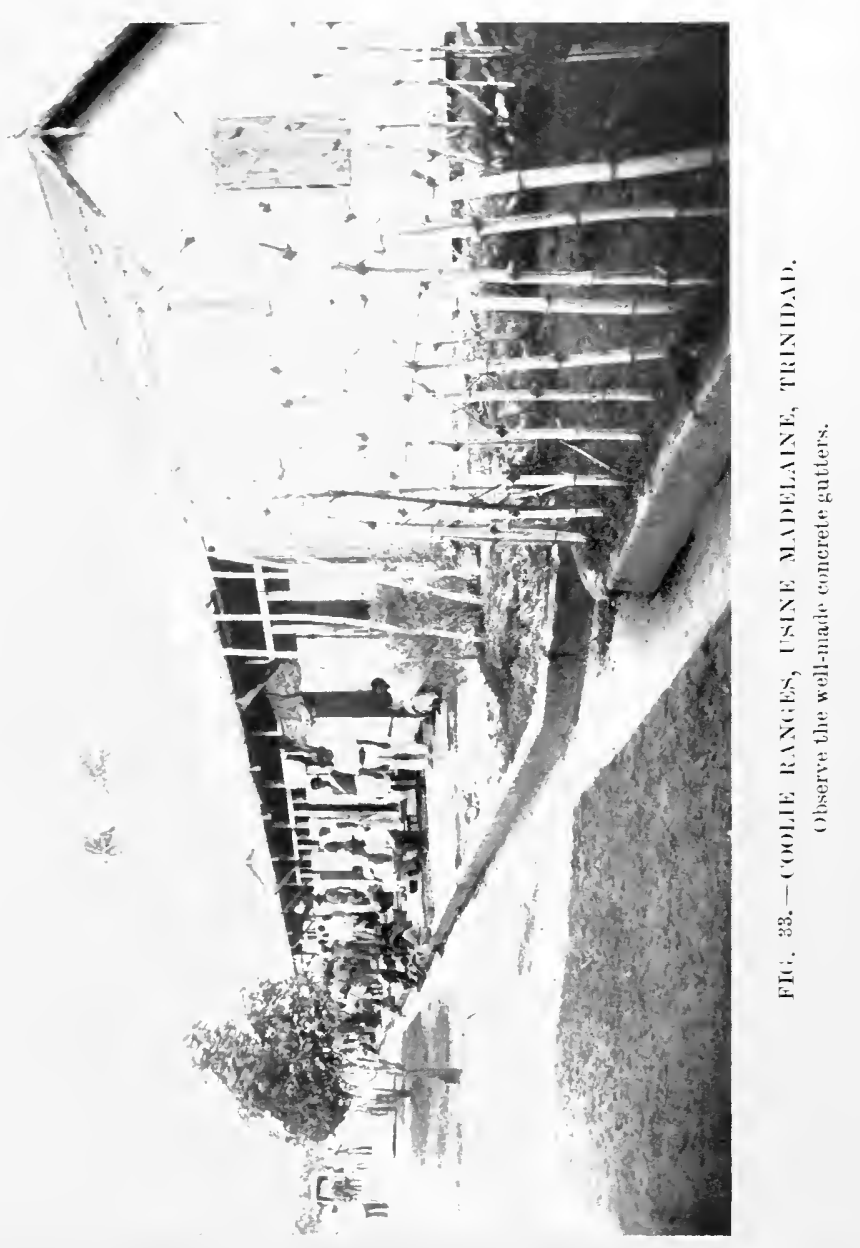



of giving every assistance in the carrying out of these measures, including the providing of the necessary appliances for the examination of freces. I regret to say that the estate authorities generally have not responded cordially to this appeal, and consequently little has yet been done to carry out the scheme indicated."

\section{Labour and ANkylostomiasis.}

As far back as November 1901, the Hon. G. T. Fenwick and Mr Meaden recommended attention being given to the prevention and modification of ground- or wateritch, and for this purpose a committee was formed and a circular drawn up, based on recommendations by $\mathrm{Dr}$ Bennett. The report and circular are as follows :-

The committee having carefully considered the letter of Mr T. H. P. Heriot and the papers by Drs A. B. Dalghalty and R. C. Bennett on this scourge of the field-labourers of the colony, beg to report :-

That in their opinion the disease is so prevalent and incapacitates from time to time such large numbers of our labouring population, as to render imperative the adoption of such measures as will best tend to its prevention or the mitigation of its severity.

To enable the society to recommend to employers of field labour the best measures to be adopted, the committee think the employer's should be invited by the society to make a careful trial, extending over a period of twelve months, of one or other of the several treatments for prevention and cure recommended by $\mathrm{Dr}$ Bennett, and to keep a correct record on certain welldefined lines of their observations and the results of the trial, such record to be forwarded to the secretary of the society at the end of twelve months. 
A form of circular letter to be addressed to the employers is herewith submitted.

The report of a commission on the labour question (agricultural) in the colony, presented on the 5th February 1906, stated : "The Surgeon-General attached the greatest importance to ankylostomiasis, or grounditch, attributing to it the prevalence among fieldlabourers of anæmia, which, in its turn, produces liability to other diseases and permanently impaired energy. . . . We have already touched on the farreaching effects of ankylostomiasis, and we need now only point out to Your Excellency the desirability of adopting here the preventive measures adopted in British Guiana with gratifying results, and advocated for Trinidad by the Medical Inspector of the Indian Government some thirteen years ago."

Recommendations were made, at the instance of the Secretary of State, by the Surgeon-General, for the control of ankylostomiasis. In the first place, a return of all cases in estate hospitals and on plantations, as well as a report for the last four years, was drawn up by the Surgeon-General. An ordinance was then drafted, and this ordinance has been criticised and reported upon, and modifications and strengthening suggestions made by the Surgeon-General.

I am of opinion that the measures proposed by the Surgeon-General should be put into practice in order to stamp out ankylostomiasis.

\section{Proposed Ankylostomiasis Ordinance.}

Employers of agricultural labour to provide proper latrines, under penalty, and any person defecating except in a latrine to be liable to a penalty.

Object: To prevent pollution of surface soil.

Note.-This draft ordinance stands referred for a report from a committee, and is now receiving attention. 


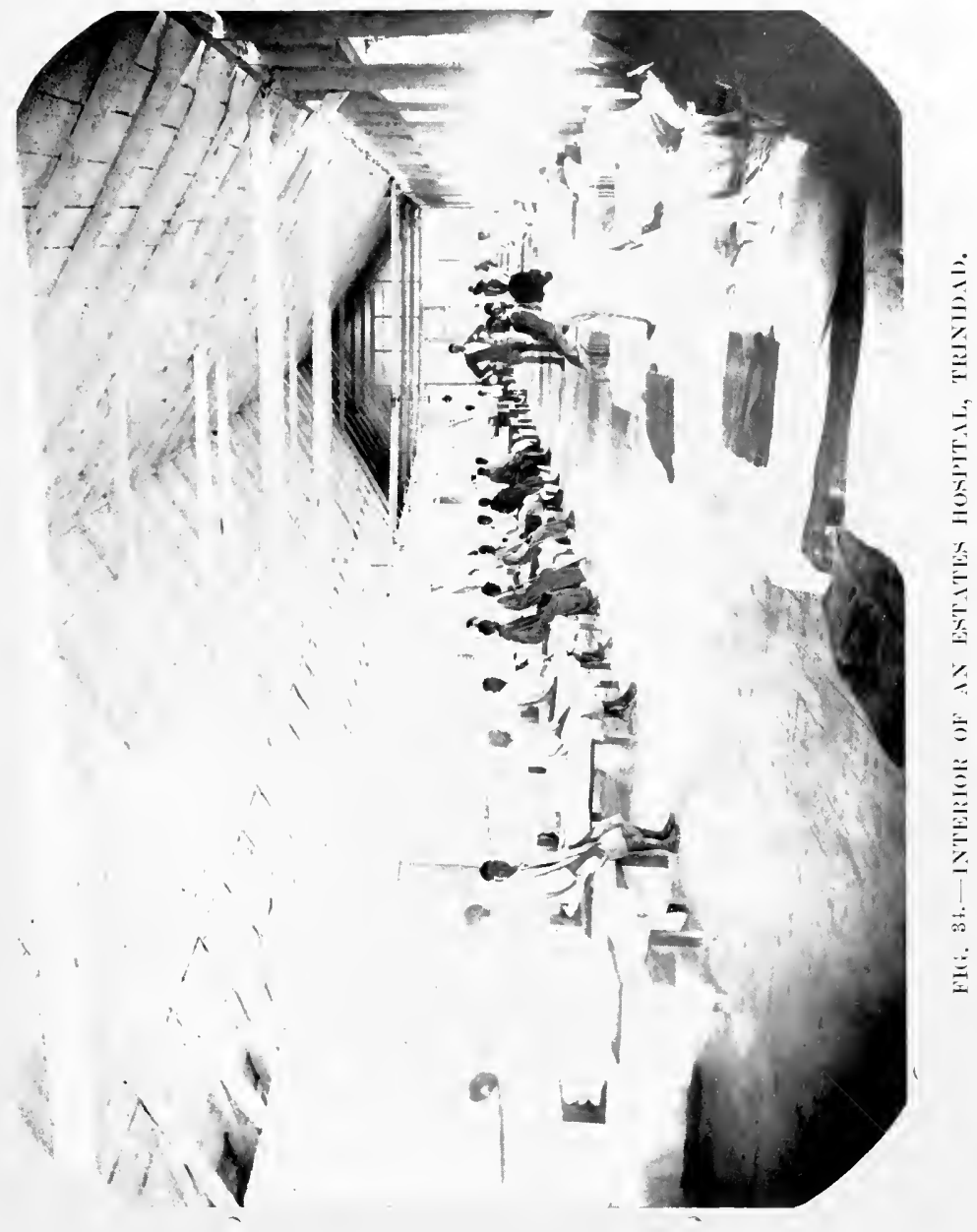

ב⿱艹

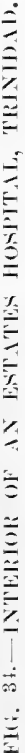



Plague. - As has already been seen in a previous chapter, plague occupies a large and anxious share of the attention of the Government ; regulations have been drafted in respect to it, and a vigorous sanitary inspection of all the poorer quarters of the town maintained, as well as precautions taken against rats (see Appendix). I have already fully commented upon the necessity of strict supervision of arrivals from Venezuela.

Smallpox has also received a considerable share of attention, and an interesting report has been drawn up and published by Dr R. Seheult. The subject of smallpox in its various modifications is one well worthy of scientific study in the West Indies (see Appendix).

Tuberculosis.-A society has been formed in Trinidad for the prevention and treatment of tuberculosis. The society is doing good work by means of a dispensary, and by publishing leaflets containing instructions for the prevention of the disease.

Leprosy. - An interesting report upon this disease for the year 1890 has been drawn up by the Acting Superintendent of the Leper Asylum; he states that :-

Tuberculosis occurred in seven cases of tuberculated leprosy, in two cases of mixed leprosy, and in none of the anæsthetic variety. These give as percentages :-

$\begin{array}{ll}\text { In tuberculated leprosy } & \cdot \quad \text { about } 66 \text { per cent. }\end{array}$

Dealing in a similar manner with diseases of the kidney, he found that it occurred as follows :-

In tuberculated leprosy . about 36 per cent.

" anæsthetic leprosy . " 11 "

The figures are too small to enable any inferences to 
be drawn, but are perhaps worth preserving as showing the frequency of occurrence of these diseases in the different varieties of leprosy. The absence of any form of tuberculosis in the anæsthetic variety of the disease is to be noted.

I visited the leper asylum and was much impressed with the care and attention bestowed upon the patients by the devoted Roman Catholic Sisterhood in charge; in my opinion, the colony is fortunate in being able to secure the services of this earnest and humane body of women. What is lacking is the spirit of research in the medical profession. Would that this could be revived, and more encouragement given it, not only in the West Indies, but here at home.

Ordinance No. 190.-The lepers' ordinance deals fully with the regulation, isolation, and care of lepers.

San Fernando General Hospital.-On 16th May I visited San Fernando, and inspected the hospital, which is very well arranged and equipped. The institution has a pathological department under Dr Seheult, and it contains many interesting specimens. Dr Seheult is busily engaged making investigations. There is an excellent mosquito-proof room in the hospital for the reception of suspects. I saw Dr Fabien, who is torwn Medical Officer of Health. The sanitation of San Fernando is not as advanced as that of Port of Spain, and much yet is to be done in the form of watersupply and drainage. More sanitary inspectors are required in all the smaller towns.

Yaus.-I visited the Yaws Hospital, Tacarigua, with 
Dr Clare and the doctor in charge (Dr Alston). Total number of cases, 184. A very large proportion of the cases were in young subjects from one to fifteen years. No evidence that there were any congenital cases. Indians formed about 50 per cent. of the cases. The arrangements in the hospital were excellent, and from an examination of the earlier records there is no doubt that since the institution of the hospital there has been a marked decrease in the total number of cases, so that bringing in the patients under control and supervision has had a very beneficial effect. There is a special Yaws Ordinance, No 191, which deals with the notification, segregation, and care of cases of yaws. 


\section{CHAPTER XV}

HEALTH PROGRESS AND ADMINISTRATION IN BRITISH GUIANA

I ARRIVED in this colony on 19th April 1909. British Guiana has been described as the "Tropical Holland," and, by the less ambitious, as an alluvial "mud-flat," stretching towards the sea-line, on which Georgetown and New Amsterdam are built. Numerous large rivers run through it to the sea, and it is cut up into lots and plantations by innumerable canals and trenches. Every roadway has a trench on either side of it; for it is only by excavating upon each side that a dry solid road can be constructed. The appearance of this flat, lowlying, alluvial plain, cut up into rectangular strips by middle and side dams, middle and side trenches, is very striking to the newcomer; and the longer one studies the country and its treatment, the more one marvels at the ingenuity and the pluck of those pioneers who showed how, in spite of all obstacles, a low-lying swamp can be made into a beautiful and productive country, with good solid roads and avenues, along which it is now a delight to motor.

"As the level of the land," wrote Blair, "is below 228 


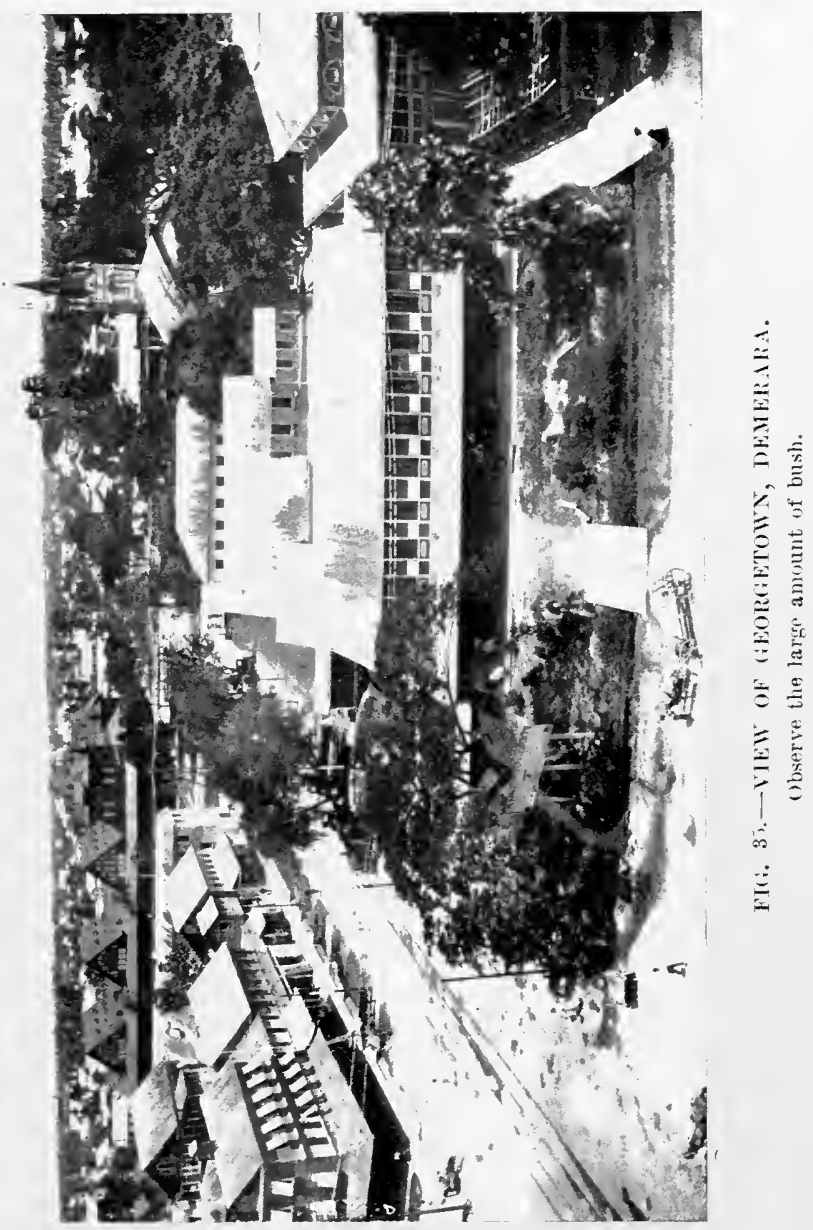



that of the sea, the cultivated lands require embankments on every side. Sluices in the embankments when the tides are suitable give vent to the surface drainage of the land. Numerous drainage and navigable canals intersect the country. Within Georgetown, in 1837, besides a few private drains, there belonged to the public 31 miles of open trenches, varying in width from 2 to 10 feet, communicating by 62 tunnels, and these required to discharge the surface-water of the city alone !"

The great obstacle to our forefathers in British Guiana was the intolerable mosquito-not that they then thought so, for then they considered that the marsh miasm, which we have already in the opening chapter discussed, was the cause of all fevers. They considered their adopted country the veritable factory of miasms, with mudbanks and swamps everywhere, and the odours arising therefrom, so bad in Georgetown down by the stellings, that the freshly painted white houses were soon covered by a thin deposit of black metallic lead, caused, as we know, by the conversion of the white oxide of lead in the paint into the black sulphide by the sulphuretted hydrogen emitted from the marshes. In those days, when white houses were being turned black in Georgetown, the city was one of the notorious "abodes of death," to the port of which sailors were only induced to go under false pretences, believing when they joined their ship that they were going to some other place with a more savoury reputation.

Those were the days, as we have seen, when the Secretary of State ventured an enquiry why 69 per cent. 
of the garrison perished from yellow fever! They were the times when every new arrival as a matter of course got yellow fever within a few weeks of arrival. We have records of fever in 1819, 1820, 1821, 1824, 1825, $1826,1828,1830$, and 1831, and in the years 1820, 1821, and 1825, yellow fever is specially mentioned. In 1820 the mortality from that disease is given as $\mathbf{1 6}$ per cent.; in 1821 , as 14 per cent. ; and in 1840 it was as high as 69 per cent. Far from this scourge disheartening the inhabitants, it, on the contrary, set men's minds thinking, and British Guiana will always stand out as a colony in which great medical knowledge has been a striking feature. The distinguished but forgotten Beauperthuy, as we have seen, finally settled in the colony; then later Daniel Blair became Surgeon-General. Both these men have left works behind them, showing that they were far in advance of the profession of their time, and were preparing the way for the great scientific discoveries of a later age. Blair's account of the yellow fever epidemic in British Guiana between the years 1837 and 1842 is full of interest and well repays study, especially in the light of modern knowledge. The reader will get a picture of Water Street, Robb Town, the Stellings, and Eve Leary barracks, and the mudlots in 1847, which, if he knows the Georgetown of today, with its 60,000 inhabitants, will convince him that every tropical country, whether above or below the sealevel, has a future, and one which is all the more easy today to accomplish, seeing that we know exactly how to meet disease. In my opinion, Demerara should be taken as the example of what can be done in the tropics 


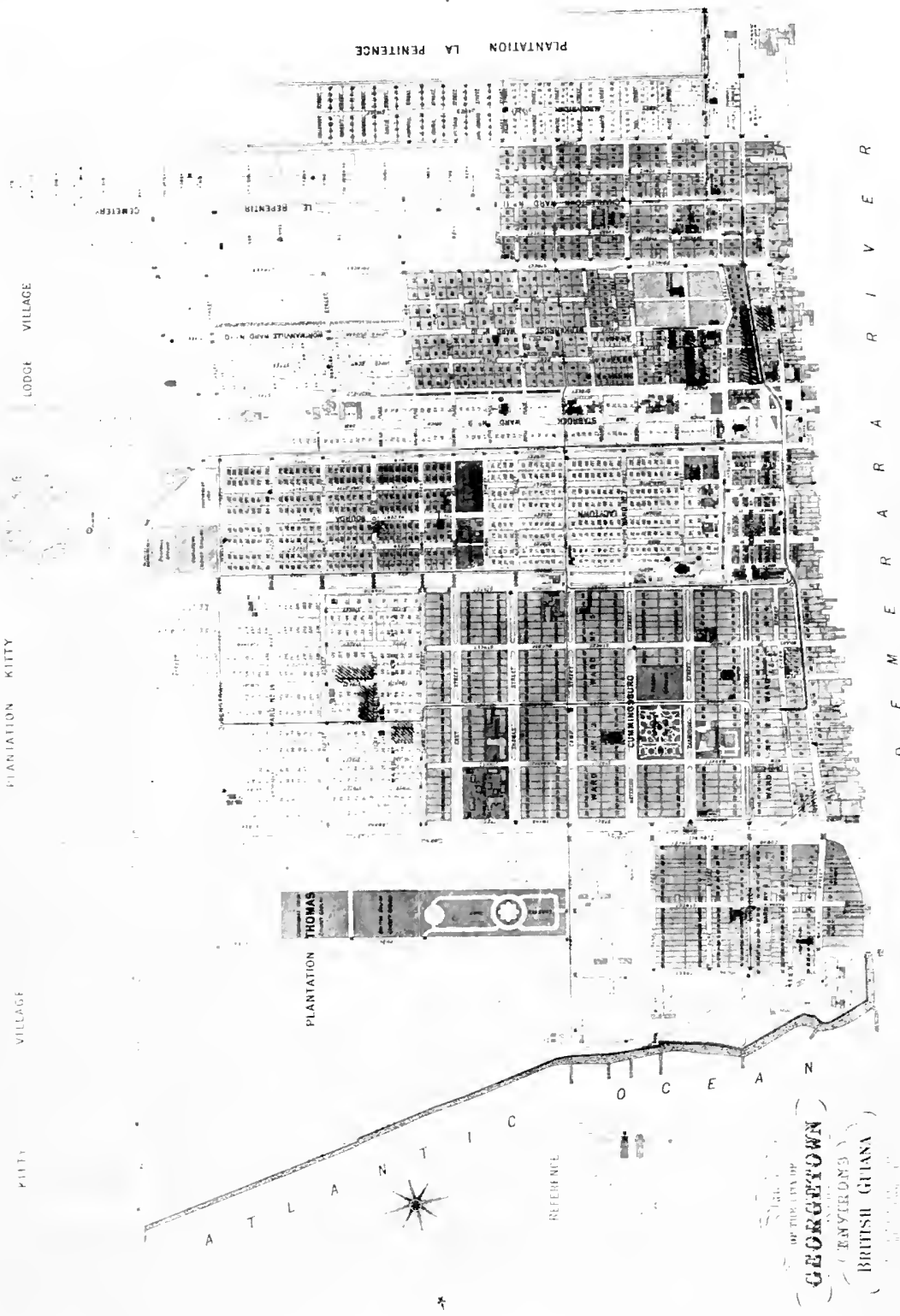



by intelligence and perseverance. The total population of British Guiana is now given at 354,549.

History of Yellow Fever in recent times.-Since 1888 up to the present time, there appears to have been no cases of yellow fever.

Here, therefore, is another example in the West Indies of the disappearance of yellow fever. The last large epidemic was in the year 1881 ; to what, then, must we ascribe the diminution and suppression of the disease? In this particular instance we cannot, with the certainty that we did in the case of the other islands, refer the immunity to the water-supply; as far as I am able to ascertain, a partial pipe-borne water-supply was introduced in the forties; rain-water has, however, continued to be the chief source of supply. It is stored, as of old, in large vats or in barrels and other receptacles. We are therefore driven to seek additional causes for the yellow fever immunity which Georgetown has experienced during the last decades. Probably the explanation lies in far stricter quarantine supervision, better housing, general sanitation, and medical organisation. These factors have led to security just as they did in New Orleans up to 1905, in spite of the fact that the Stegomyia was breeding in abundance in the numerous unscreened vats and barrels. But in 1905, when yellow fever had broken out widely over Central America, infection found its way into New Orleans, and in a few weeks that city was face to face with a great epidemic. This only shows that, given the entrance of a case of the disease and the conditions at hand for its spreading, as for example the presence of the Stegomyia, then all the 
other sanitary reforms are of little avail. In the case of Georgetown, yellow fever has fortunately been kept out, but, had it got in, it would have found the Stegomyia in abundance ready to spread it, for the Stegomyia was the common house-mosquito of Demerara.

Stegomyia Survey.-I made my house-to-house inspection in company with the Surgeon-General and Mr Luke M. Hill, Town Superintendent. Altogether I examined 33 lots in the poorer district of Georgetown; in these there were 44 large vats, 77 water-barrels, 42 washing-tubs, 19 buckets, 5 jars, and 7 kerosene tins, and in addition, small odds and ends. Practically all the barrels and a considerable proportion of the other receptacles contained larvæ with one or two exceptions ; no vats had been screened, as at the time of my visit screening had not been enforced. It was interesting to observe the immediate effect which the water-barrels had in favouring the development of the Stegomyia-larvæ were invariably present. Some of the yards were waterlogged, owing to their low level, and in consequence looked dirty. But in my opinion the most serious disadvantage under which the inhabitants laboured was the excess of bush which had grown up, and which gave rise to a vast amount of litter and kept the sun and fresh air out and the yards damp. There is a very great disadvantage in allowing bush to grow up in the yards in town. It gives cover to mosquitos, and, as many of the plants retain water, they encourage breeding. Worse still, the litter from them is excellent cover for rats and fleas, and so they encourage these most dangerous pests, and therefore the spreading of plague, 


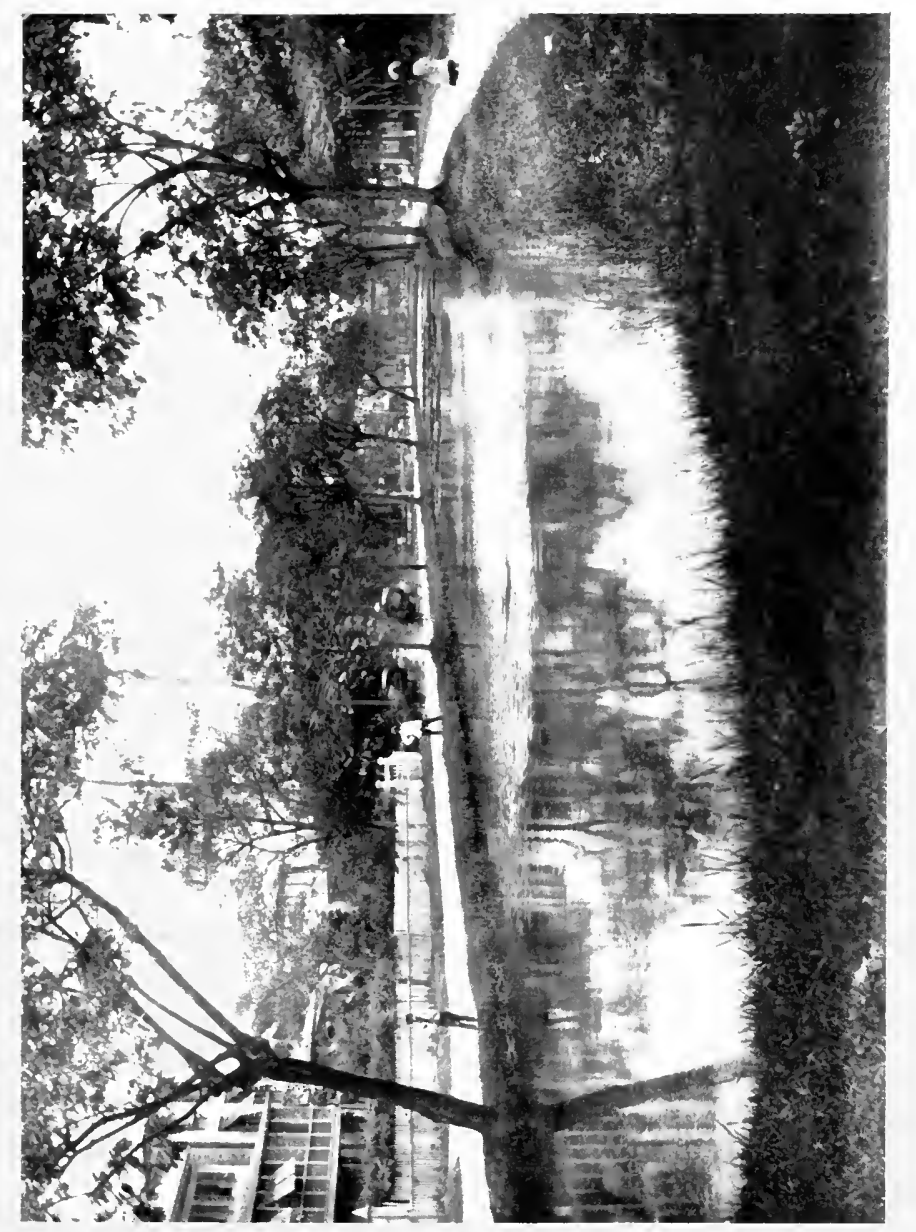

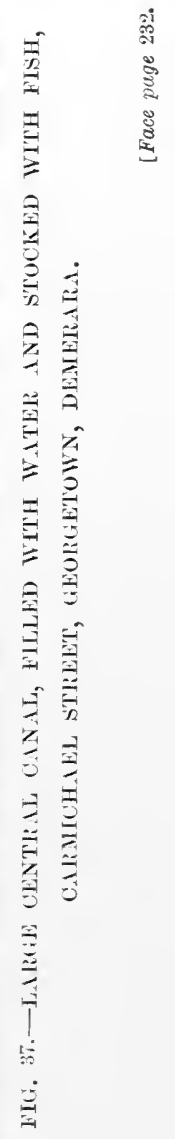



when once introduced. Moreover, by excluding the fresh air and contributing to the general dampness, it encourages tuberculosis. I am therefore convinced that from the public health point of view the yards should be thoroughly cleansed of all bush in the town. Ornamental trees along the roads are very beautiful and need not be interfered with, provided that their litter does not in any way obstruct the side drains and trenches. In the tropical world, wherever there is a tendency to plague or mosquitos, particular attention must be directed to bush clearing; it is rightly regarded as second only to drainage in importance.

On 22nd April I visited the town of New Amsterdam, Berbice. I made a tour of inspection with the Mayor and Town Council, Dr J. E. Godfrey, Dr De Freitas, the sanitary inspector, and the Rev. J. Aitkin. I inspected in Pitt and St Ann Streets fifteen yards belonging to houses contained in two lots. In these fifteen yards I found-

$\begin{array}{lllllr}\text { Barrels } & . & . & . & . & 40 \\ \text { Vats } & . & . & . & . & 8 \\ \text { Tubs } & . & . & . & . & 11 \\ \text { Tins } & . & . & . & . & 2 \\ \text { Buckets } & . & . & . & . & 5\end{array}$

this shows that there is a vary large excess of barrels used for storing water-chiefly rain-water. In ten out of the fifteen yards larvæ were found in the barrels, and the barrels nearly always contained larvæ. This shows that in New Amsterdam the barrels almost invariably contain larvæ, and this is the experience of others. The larvæ were those of the Stegomyia. With the Rev. J. Aitkin I examined in Stanley Town a small pond in a 
field and found Anophelines; he assured me that Anophelines, were, however, not to be found in the ditches. On 26th April I visited the Diamond Sugar Plantation, in company with the Surgeon-General and Dr Law, the medical inspector of the colony : there were many barrels for holding the domestic water, but they were all screened by means of copper gauze, and contained no larvæ.

The Study of Entomology in British Guiana.-Although the colony possesses no official entomologist, it is fortunate in possessing medical men and the Rev. J. Aitkin, who have devoted much attention to the breeding places of mosquitos. Drs Ozzard and Rowland and $\mathrm{Mr}$ Aitkin have contributed much to the mapping-out of the distribution of mosquitos in the colony. Mr Aitkin has been good enough to furnish me with the following memorandum upon the distribution of disease-carrying mosquitos in the New Amsterdam district. ${ }^{1}$

Cellia albipes and argyrotarsis.-The former is the most common Anopheline in New Amsterdam. It is found in ponds and in smaller collections of water at or near the ground-level, and in all manner of receptacles lying on the ground, such as tins, calabashes, etc., also in water in tree stumps about 20 inches from the ground. Not found as yet in trenches, vats, open iron tanks, nor in drains or standpipe-pools. $\mathrm{Mr}$ Aitkin adds :-

"I have made extensive observations over a large area of the colony, from Spira Village, about 100 miles up Corentyne River, on the Eastern boundary of the

1 His paper on the mosquitos of British Guiana has just appeared in the British Guiana Medical Annual, 1909. 


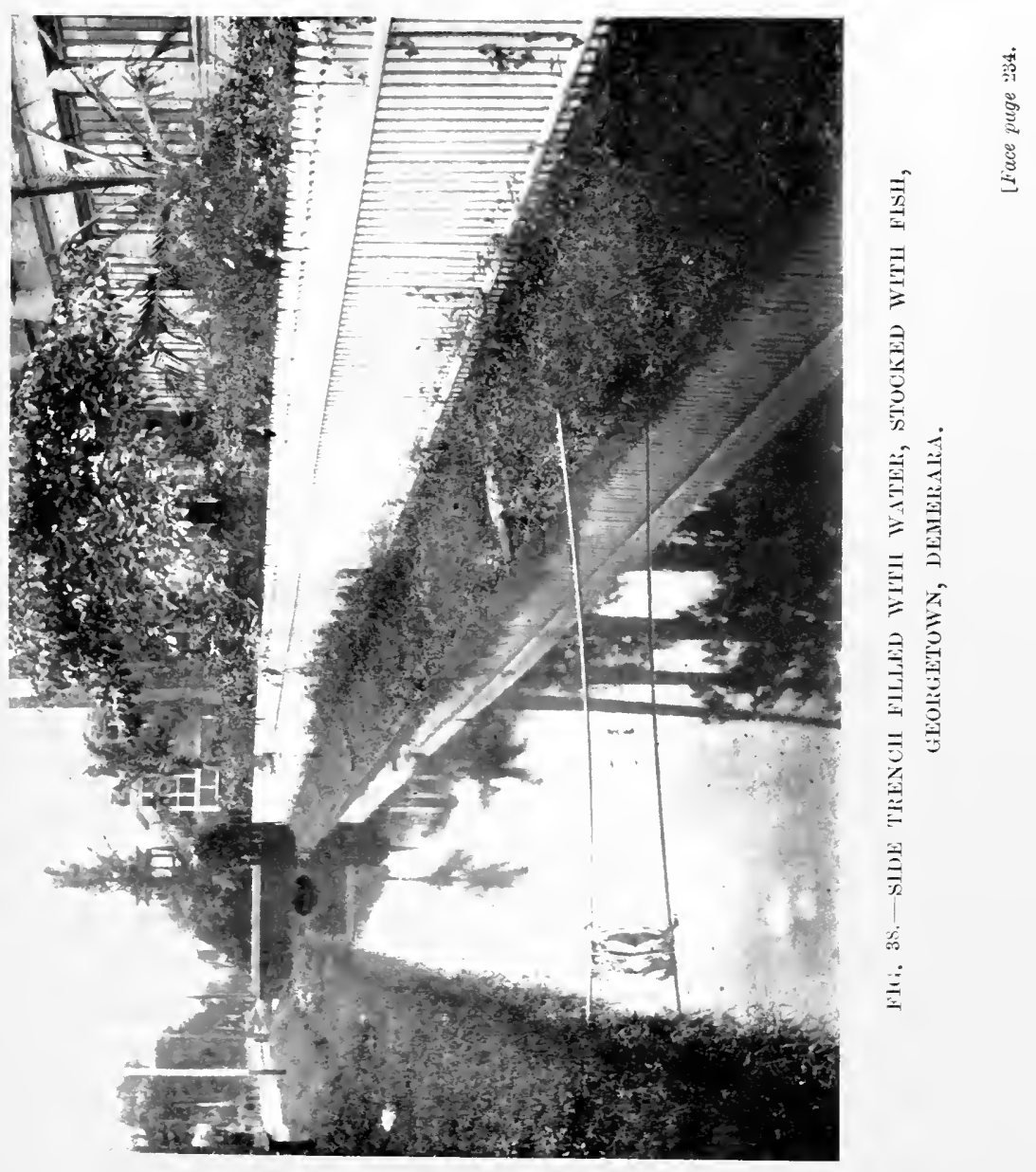



colony, at points on the coast from Skeldon to New Amsterdam; in Georgetown, and on West Coast, Demerara, Chalkhill Village, and Supenaam Creek, Essequebo, and my experience of the absence of Anopheline larvæ has been repeated without exception.

"Stegomyia calopus is found in vats, barrels, gobis, calabashes; refuse ware of all sorts; cisterns supplying baths, etc., those with pipe projecting an inch or two above the bottom; especially flower-glasses ; buckets (in houses and outside); small pools beneath houses; in tree stumps near houses; iron tanks at stables, etc. ; always in clear water.

"It is not found in trenches, nor exceptionally in the large iron tanks at hospital, New Amsterdam, though I examined carefully the matter from the bottom of two of these, bucket by bucket, as the tanks were being cleaned out on one occasion, and repeatedly when tanks were full. These tanks were curiously free from culicid larvæ, though larvæ cases of various gnats were frequently found by me in them.

"Culex similis and fatigans found in all the above places and also in foul trench-water, dirty barrel-water, in hollows in large sandbox trees, and in ponds."

As the colony is intersected by miles of fresh-water canals and trenches, and as rice is now being cultivated, the question has arisen: How far do these necessary large collections of water contribute to the breeding of mosquitos-more especially, of course, the harmful kinds? $\mathrm{Mr}$ Aitkin, from his experience, states as follows :-

The Trenches.-." As noted above, my varying experience of trenches has been failure to find larvæ of Anophe- 
lines and Stegomyia. What importance they might assume were other breeding places barred, I cannot of course guess. At present I am satisfied they are not a factor in the problems of malarial and yellow fever."

"The drainage trenches are at certain seasons the breeding place of Culex toniorhynchus in countless numbers, and other culices of the fatigans type. Fish of the 'millions' variety keep the clear, fresh-water trenches free from all larvæ, and, except after long dry weather, fry of mullet, etc., abound in drainage trenches and keep these also free of larvæ. A little care and no expense, except that entailed in flushing during a month to six weeks annually, would probably do away with the mosquito plague in New Amsterdam, which gives the town its reputation as a mosquito-haunted place, C. tceniorhynchus has of course not been identified as a disease-carrier, but I have felt a degree of physical disturbance from his attacks which almost amounted to a pathological condition, with slight rise of temperature and sensation of tiredness. This, I may remark, was after some fifty minutes exposure in a boat in a trench hedged in by bush, and fortunately narrow, as Mark Twain said about the smells in Constantinople, for, if the trench had been wider it might have held more mosquitos."

"As previously noted, no Anophelines have been found in vats; Stegomyia and culicids have adopted them, but the latter only resort to them if no other accommodation is available. Culices of the futigans and similis type seem greatly to prefer any open water vessel partially shaded to the covered vat. At the Manse at Anchlyne, 

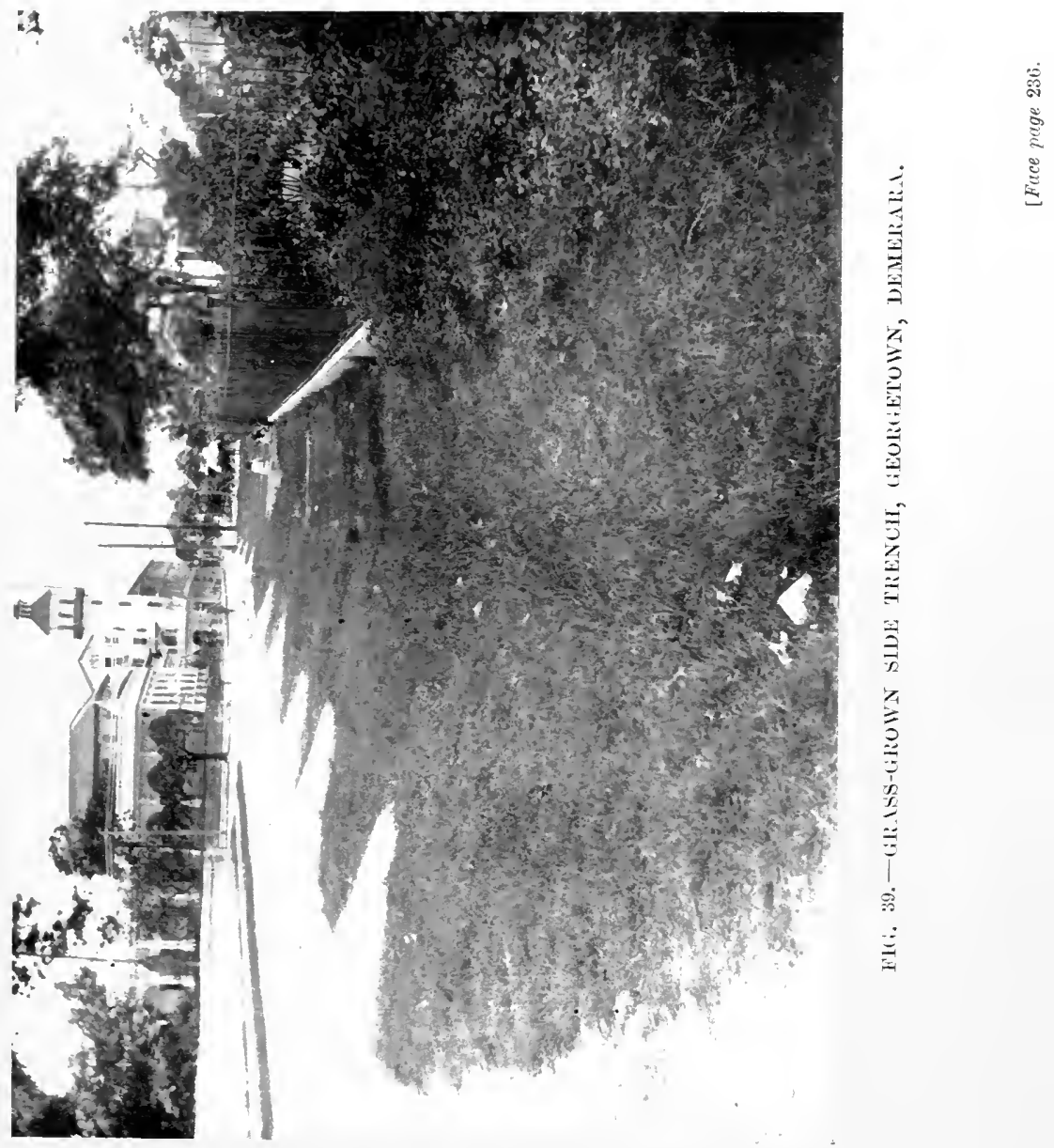

however, where, by the way, no other water was at the time arailable except in the trenches, I found numerous larva of $C$. cubensis (allied to fatigans) in the vat actually beneath the house as well as in other vats in the yard. In my vat here, there are plenty of $S$. fasciata larvæ, but no other species whatever."

"The ponds are far and away the most prolific source of malarial mosquitos in New Amsterdam and district. In several ponds in which fish of the 'millions' type are numerous, repeated examination has revealed no larvæ. In one instance, I managed to get Culex larvæ, but on frequent occasions before and after I failed to find them. Where no fish were found, larvæ of various Culicince and Anophelince were invariably plentiful."

In view of the above and other observations, it appears that the trenches and canals do not as a rule breed Stegomyia or Anophelines. This is no doubt due to the fish which are present, and it shows that in a country notorious for its innumerable waterways and swamps that the danger from malaria or yellow fever does not arise from them, but from the small collections of water in and around the dwelling-places. The fish look after the waterways, and it is the imperative duty of the sanitary authority to assist the fish, and to look to the vats and barrels-that they are screened, and that there are no odd receptacles in the yards or small pools of any kind.

Antimosquito Measures-An examination of the various reports of the Surgeon-General, and of the Town Board, as well as the original scientific papers 
which have appeared in the British Guiana Medical Journal, clearly disclose the fact that the medical profession and the Government had become fully alive to the importance of taking action against the mosquito. In his 1901-2 report, the Surgeon-General urged the necessity of adopting the various antimalarial measures which had at that time been advocated, such as drainage, the use of nets, and the taking of quinine, and he has repeatedly urged the importance of drainage (see Malaria). In February 1906, Councillor Wallbridge wrote a vigorous memorandum on the subject of mosquitos to the Town Council, pointing out that it was the duty of the Town Council to act now that the facts had been proven. He stated: "Much has been done in Georgetown in the direction of mosquito extermination, and the Town Superintendent deserves great credit for the improvements he has made, which have all tended towards the abolition of the mosquitos, such as levelling of the streets and grading, filling up street puddles, construction of well-graded concrete drains, the frequent collection of rubbish and its destruction, drainage of stagnant water, filling up of stagnant pools, removal of tins." I thoroughly endorse this statement: much has been done. Dr Wallbridge then proceeds to point out how the householders can assist the Town Council by doing some antimosquito work themselves. He also makes some very trite remarks about curtailing the size of the canals and removing weeds, and the trimming of the edges, stocking them with fish where necessary, and also oiling if the other means fail; he also recommended a scheme for flushing. 
A drainage committee of the Town Council was formed, and they suggested in their report, that the Council's efforts should continue unabated, not only insisting but seeing that the rubbish in the yards of the town are removed and the vats and the other receptacles for drinking-water properly protected by gauze. On 8th March 1909, Dr Wallbridge wrote: “The practical point is that the Town Council are responsible for the health of the town, and they are not doing the duty they have sworn to do, so long as they are not doing all they can do to exterminate mosquitos in the town."

Mosquitos are like tourists: if they do not find accommodation in the town, they will cease to stay there.

Under New Ordinance 13 of 1907, new regulations were made enforcing proper drainage of lots in Georgetown. In the same year, mosquito prevention bye-laws were also introduced to compel the screening of all vats and other vessels.

They were not, however, enforced until this year, when very vigorous action was taken, and up to July some 1700 vats were screened (see Mosquito Laws).

I have now brought forward evidence to show that in spite of most serious natural difficulties, British Guiana has done a great deal to rid itself of mosquitoborne disease; of course a great deal remains to be done yet; but as the various authorities have done so well in the past, there is not much fear that they will depart from their vigorous and commerce-promoting policy of waging war on insect pests.

Malaria and its Prevention in British Guiana.-In 
1905, His Excellency Sir Frederic Hodgson, K.C.M.G., appointed a Commission to enquire into the general mortality of the colony, which was very high. In this report the cause of the highest mortality is stated to be malaria.

Thus the deaths from malarial fever in

\begin{tabular}{|c|c|c|c|}
\hline 1904 & . & . & were \\
\hline 1905 & . & . & " \\
\hline 1906 & . & . & , \\
\hline 1907 & . & . & , \\
\hline
\end{tabular}

The monthly returns from the various hospitals in the colony gave the total number of cases of malaria as 2387, and deaths as 74, and if to these we add all the diseases directly and indirectly influenced by the cachexia and anæmia produced by malaria, there can be no doubt that malaria is the principal disease of the colony.

So impressed was the Commission with these figures, that it recommended that steps should be taken against mosquitos, as follows :-

Arrangements have been made for the sale of quinine at the district post-offices, so as to place it within reach of the poorer classes. The drug is retailed at the rate of 2 cents for 30 grains, and meets with a ready sale. It is only intended for the benefit of the people, and in order to prevent as far as possible its purchase and subsequent resale at a profit, the quantity which can be sold to any one person, at a time, has been limited to 180 grains. Later on, as a further precaution, the supplies for this purpose were ordered in tablet form, coloured pink, and stamped with the letters 


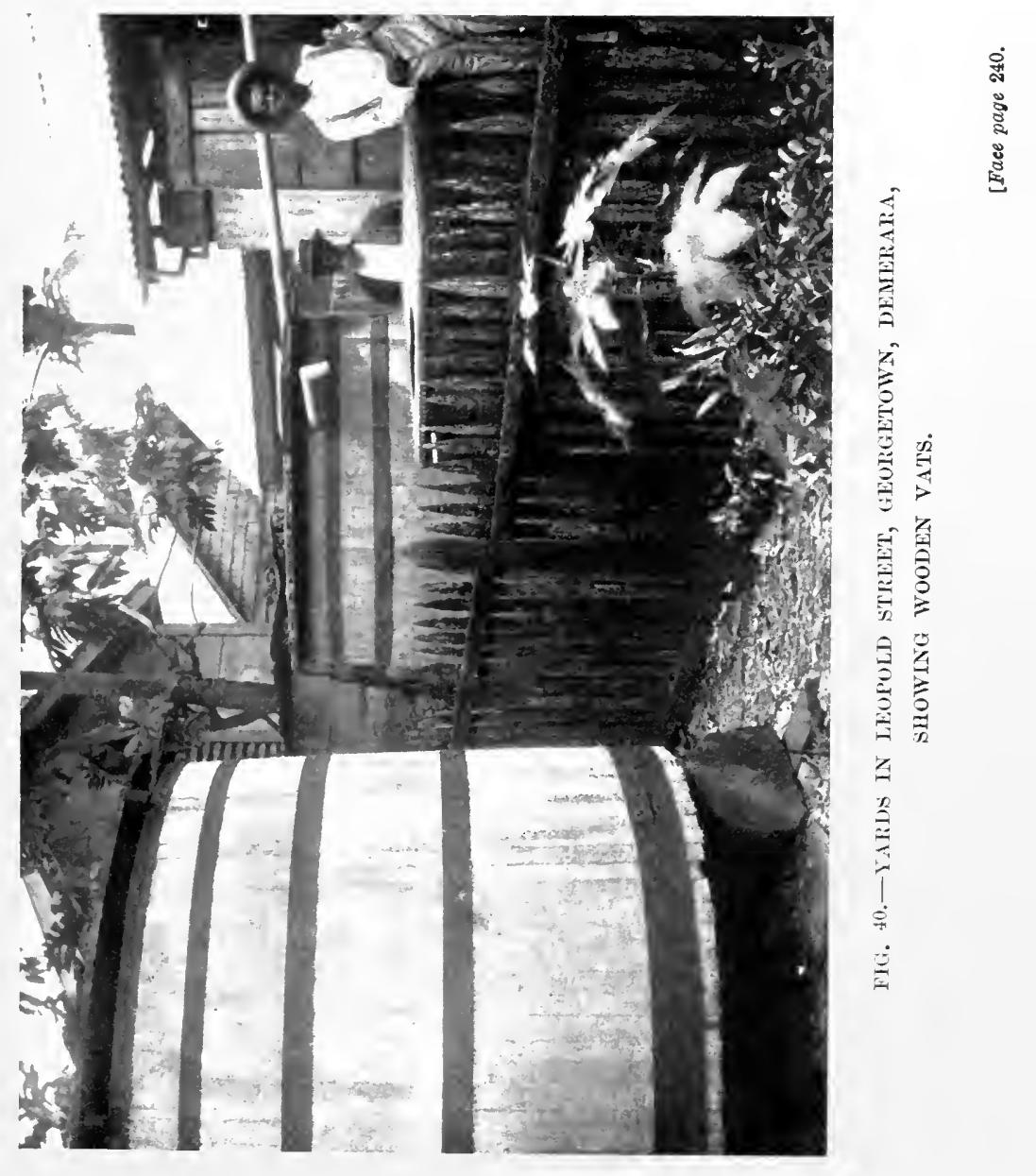



“B. G." Drainage operations, fish-stocking, removal of receptacles, and screening were also pushed forward.

Objections to Screening Measures.-A curious idea was at one time prevalent in Georgetown-namely, that as mosquito larvæ were said to be scavengers, their presence in the vats was therefore useful. People argued: Why screen, if the larvæ may remove harmful bacteria from the water? I have heard a similar argument used in British Honduras by the natives, who alleged that the presence of larvæ in water indicated that it was clean. In a certain sense this latter statement is true, as Stegomyia larvæ prefer clean water to dirty water, and hence are found usually in the drinking-water and not in the gutter-water. But on the other hand, we have no evidence whatever that larvæ remove pathogenic bacteria from water. ${ }^{1}$ The normal diet of larvæ consists of green algæ. But apart altogether from what is or what is not the food of larvæ, it is obvious that no one in their senses would trust to larvæ to remove from water the germs, either of cholera, or typhoid, or dysentery, and as we know the positive harm larvæ do when they become mosquitos, reason will, I feel sure, dictate that mosquitos should be prevented from breeding in water.

Education as a Prophylactio Factor in British Guiana.-The Mortality Commission's report referred to the importance of educating the public.

This has been acted upon: mosquito cards were prepared by Dr Wise, the Government bacteriologist,

I I have made a series of experiments which show that the presence of larva adds very considerably to the number of bacteria present. 
under the direction of the Surgeon-General, and these were distributed by the sanitary staff of Georgetown; in the same way, cards dealing with baby-feeding and tuberculosis were likewise distributed. The press of the colony has also done its share in educating the public: so that, all told, the public are in a position to-day to realise the advantage to be reaped by modern sanitary reform, and especially that branch of it which is directed against insect pests.

Mortality Returns. - As already stated, the Governor appointed a Commission in 1905 , to enquire into the general mortality of the colony.

The cause of highest mortality is stated to be malaria.

The death-rate for Georgetown is high, and appear's to be 40 per thousand.

There is a very ligh infant mortality.

The principal diseases which give rise to the great mortality amongst adults and infants is stated to be :-

Malarial and filarial diseases ;

Malaria in the country districts ; and

Filaria in Georgetown.

It is recommended, therefore, that steps should be taken against mosquitos, which are the proved carriers of malaria, yellow fever, and filaria.

\section{Death-rate per 1000.}

(Georgetown and Environs, exclusive of country patients in hospital.)

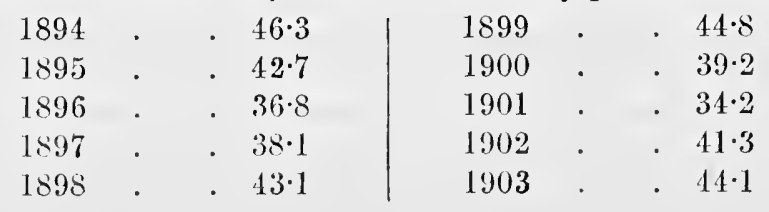




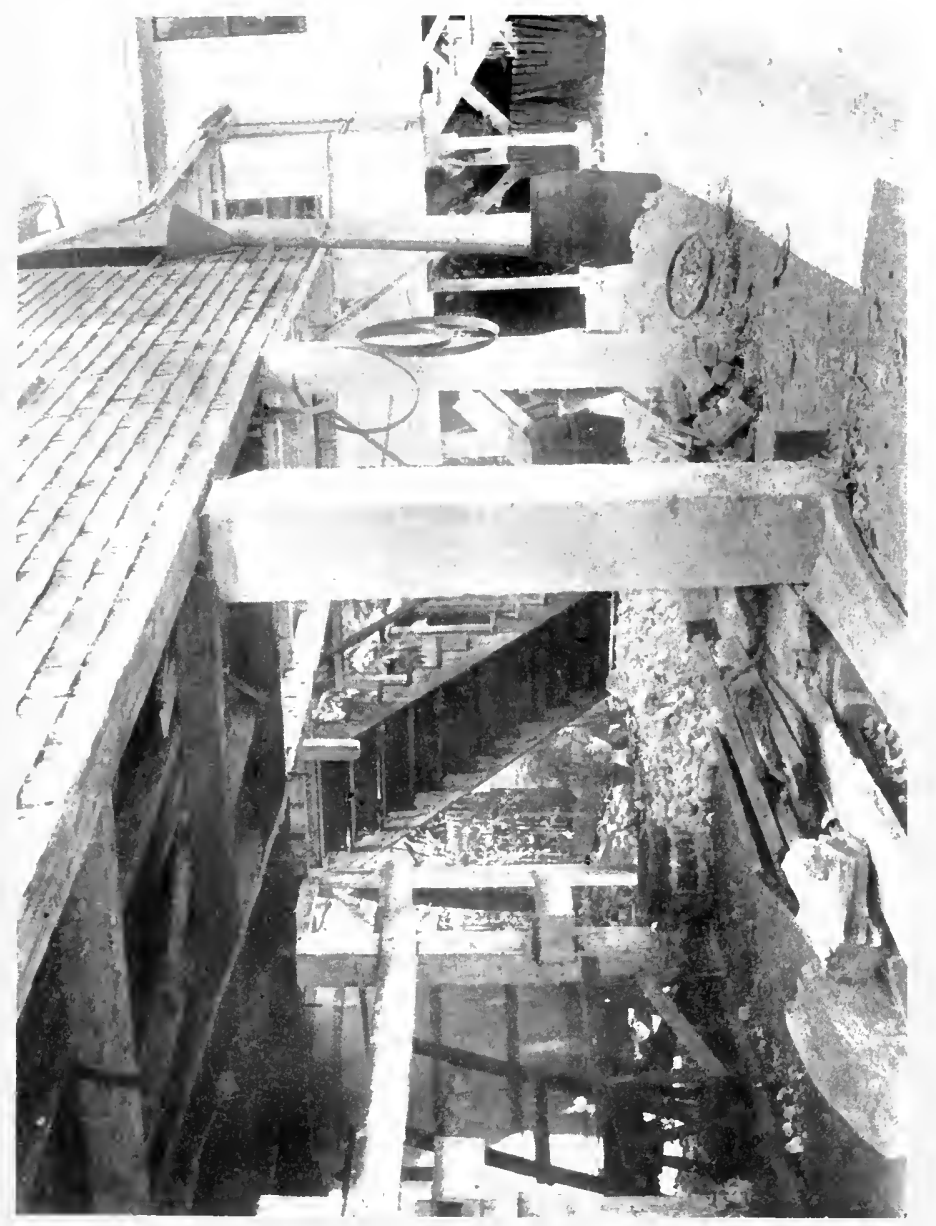

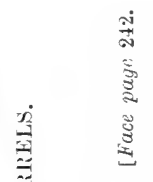



Deaths from

Ankylostomiasis

Anæmia

Malarial fevers

Phthisis and other forms
1904. 1905. 1906. 1907.

-..

-..

206

273 of tuberculosis

$\begin{array}{llll}365 & 287 & 296 & 272\end{array}$

Monthly Return of Diseases and Deaths in 1907-8 at the following Institutions:-Georgetown Hospital, Berbice Hospital, Suddie Hospital, Bartica Hospital, and North-Western District (Morawhanna and Arakaka).

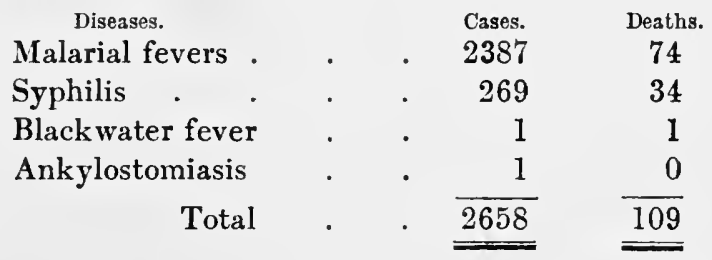

Ankylostomiasis.-The Commissioners stated that they regarded this disease as a most potent cause of illhealth amongst the coolies and also amongst the black and coloured population of the villages; 39,000 cases have been treated in the estates hospitals during the last four years. The Commissioners also stated that it was indirectly a common cause of the high mortality: for, like malaria, it caused anæmia, and this condition had a very pernicious effect upon nursing mothers, and therefore contributed indirectly to infant mortality; it also increased the gravity of diseases like tuberculosis or malaria. They recommended that efforts should be steadily made to combat the disease on the plantations and also in the villages, as it appeared that it was on the increase. They regarded the prospects of curative and preventive measures very hopefully. 
The Surgeon-General took vigorous action, and wrote a memorandum upon the subject to the Colonial Secretary of British Guiana. This was followed by circulars to all Government medical officers and to managers and attorneys of sugar estates (see Appendix). The circulars point out the necessity of accurate returns based upon systematic microscopic examination of the fæces and proper latrine accommodation. A circular was also issued by the Colonial Secretary drawing attention to the importance of suitable latrine accommodation and the prevention of defecation in the cane-fields (see Appendix for text of circulars). I visited one of the large sugar estates in the colony, known as Diamond. I went in company with Dr Law, who is the medical inspector of the colony, and travels round and inspects estates hospitals and reports to the Surgeon-General. An estate is supervised by a manager, under whom are overseers. Under these again are drivers, who look after the various gangs of labourers employed upon the estate. I inspected some estates hospitals and found the arrangements very good. I also examined several of the "ranges." They were particularly clean and well-ventilated, and, as remarked elsewhere, the waterbarrels were properly screened. On one estate there was good latrine accommodation for both males and females; I found the latrines very clean.

The question of latrine accommodation is now engaging the serious attention of the health authority of the colony, and there is little doubt that an effective system will soon be in operation on all the estates, and then it is to be hoped that similar arrangements of a suit- 


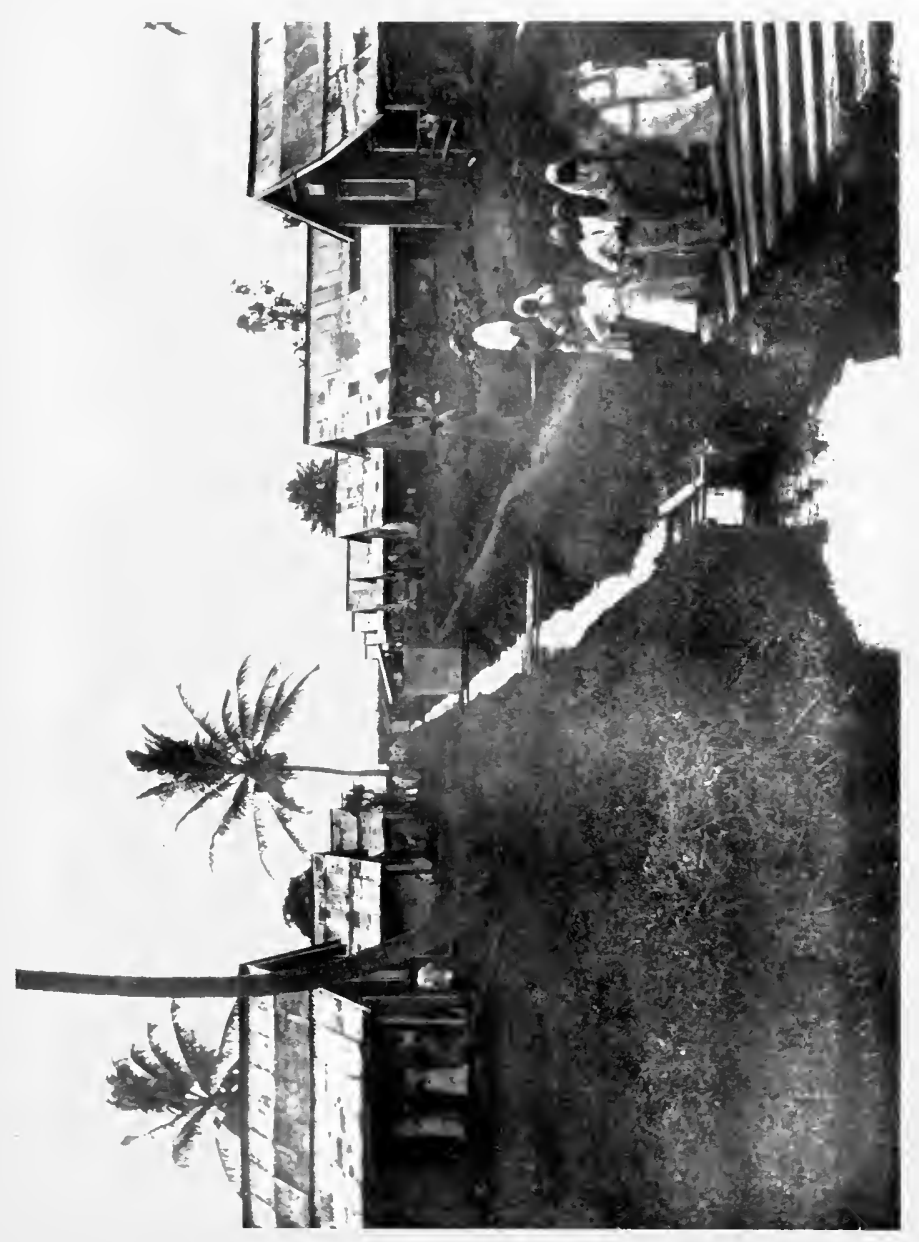

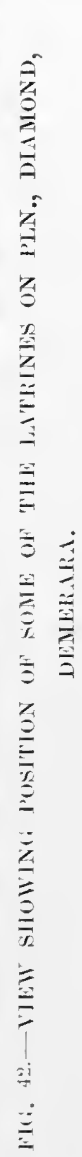



able nature will be made for the free labourers in the villages, so that this abominable labour-paralyzing and mortality-increasing disease may be overcome. In order to demonstrate the seriousness of this disease, I reproduce on p. 246 a table from the Surgeon-General's report.

After Malaria and Ankylostomiasis come tubercular affections. These are prevalent, and are due to causes into which $I$ have already gone, such as overcrowding and bad ventilation. The Government has actively taken up the matter by means of leaflets, trying to instruct the poorer classes. In my opinion, increased drainage operations and bush-cutting in the villages and towns will have a very beneficial effect.

Leprosy.-I visited the Leper Hospital, and was much gratified to find for the first time in my tour that an endeavour had been made to make original investigations, and to try new methods of treatment. Professor Deycke had made very numerous observations upon his new treatment with nastin.

Would that more investigators like Deycke could be induced to visit these magnificent colonial medical institutions for the purpose of investigation and research. No Empire gives such opportunities as the British.

The Colonial Hospital. - On 11th April I visited the Colonial Hospital with Dr Godfrey. There are 500 beds ; the hospital is beautifully organised and equipped. There is a pathological department with bacteriological laboratory and commencing library. Dr Wise is the bacteriologist, and steps are now being taken to appoint an assistant bacteriologist.

Sanitary Administration.-The Surgeon-General is 
Table showing the Number of Cases of Anchylostoma Infection on the different Sugar Estates from June 1904.

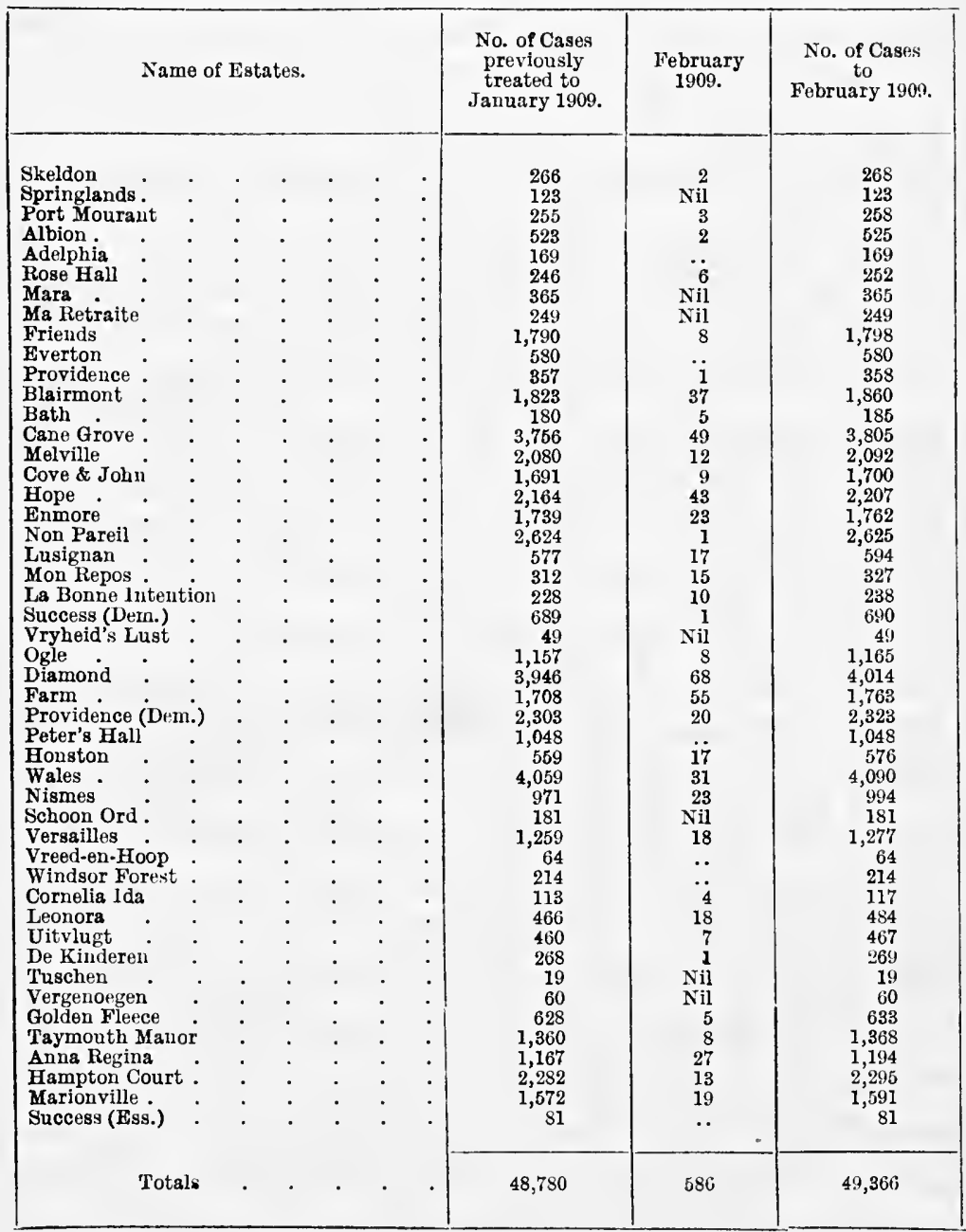




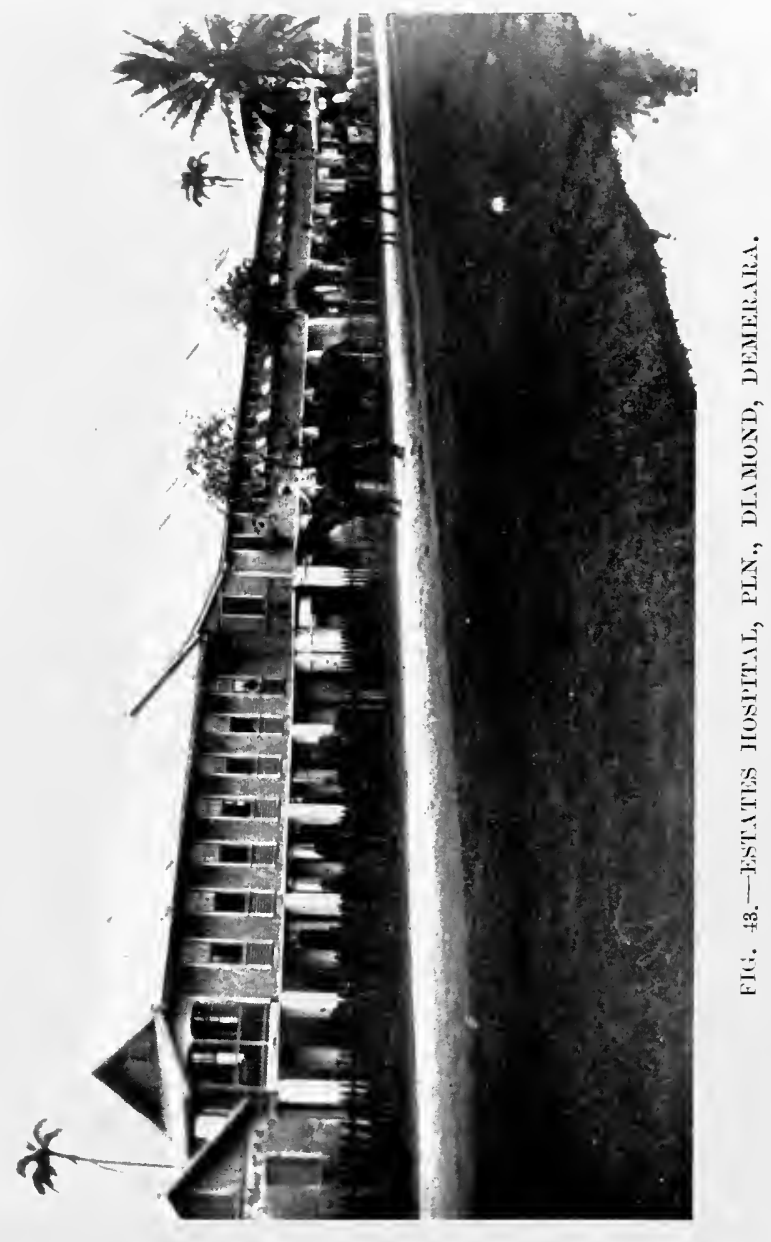



the medical head of the colony. There is also on his staff, as we have seen, a medical superintendent for the colony charged with the inspection of estates hospitals, and there is also a Government bacteriologist and various district medical officers. Georgetown, the capital of the colony, has a mayor and town council, and they have the services of a town superintendent and a medical officer of health. But as the whole services of this gentleman are not devoted to municipal and port sanitation, correspondence took place in 1908 in order to bring about the appointment of a medical officer of health for the city of Georgetown, its port and environs, whose whole time should be devoted to his public duties. To my mind, there can be little doubt that such a step would be a very wise and useful one, and would bring the sanitary administration of Georgetown and of its port in direct touch with the medical head of the colony, and for sanitary progress and organisation this is most essential.

Quarantine Administration. - So far, plague and yellow fever have been kept out. As an example of the trouble to which the want of medical co-ordination in Barbados put British Guiana, as well as the other colonies to which I have already referred in previous chapters, I quote the following correspondence:--

Tardy Notification of Barbados re Yellow Fever.

The Honourable

The Government Secretary,

I think the Barbados Government should have notified us earlier; we received the informa- 
tion ten days after the case occurred and three days after the death of the person.

2. I trust there will be a meeting of the quarantine authority at an early date, as there are, in my opinion, several matters that require to be dealt with :-

(a) The extension to thirty days of quarantine restrictions with regard to yellow fever;

(b) A place to be declared infected on the occurrence of one case of yellow fever.

\section{J. E. Godfrey, Surgeon-General.}

21st April 1908.

The Government Secretary, Mr C. T. Cox, then wrote the Government Secretary at Barbados, as follows :-

With reference to your telegram of the 16th ultimo, reporting the occurrence of a fresh case of yellow fever in Barbados, and to your circular letter No. 5 of the same date forwarding the medical report on the case, I am directed by the Governor to invite your attention to the time which elapsed between the occurrence and notification of this case, and to express the hope that every effort will be made to avoid such delay if any other cases should unfortunately occur.

The answer received was as follows :-

1. With reference to the recent cases of yellow fever that have been notified to you as having occurred in the parish of St Lucy in this island, I am directed to inform you that in consequence of rumours as to the prevalence of sickness in that parish the board of health sent down a special representative to investigate and report.

2. Dr Hutson, the officer selected, himself a member of the board of health, visited the parish, and after an exhausting enquiry made the report which is enclosed herewith. 
3. Although it is not possible to report as yellow fever cases which were not recognised as such by the doctor attending, and which were not seen by $\mathrm{Dr}^{\circ}$ Hutson, it has been considered desirable to inform all parties to the convention of the exact facts which have come to the knowledge of the Government, and of the measures which have been taken for the stricter surveillance and sanitation of the parish of St Lucy, and which are enumerated in the body of the report.

4. In this connection $I$ am to add that His Excellency regrets that there should have been delay in notifying certain cases of yellow fever. In no instance has any delay occurred when once a case of yellow fever has been reported to the health authorities; but it has unfortunately occurred that the doctors attending a case have not always been able to agree upon their diagnosis until after several days' observation, and in one case until some days after the man's death. In view of the measures now adopted, it is not likely that any further delay will be due to this cause.

It will be observed that the board of health, having no principal medical officer, sends down a member of their own board to investigate and report. In other words, they make Dr Hutson for the time being their honorary medical officer of health, and then, owing to their lack of medical organisation, the extraordinary statement is made contained in the last paragraph. 



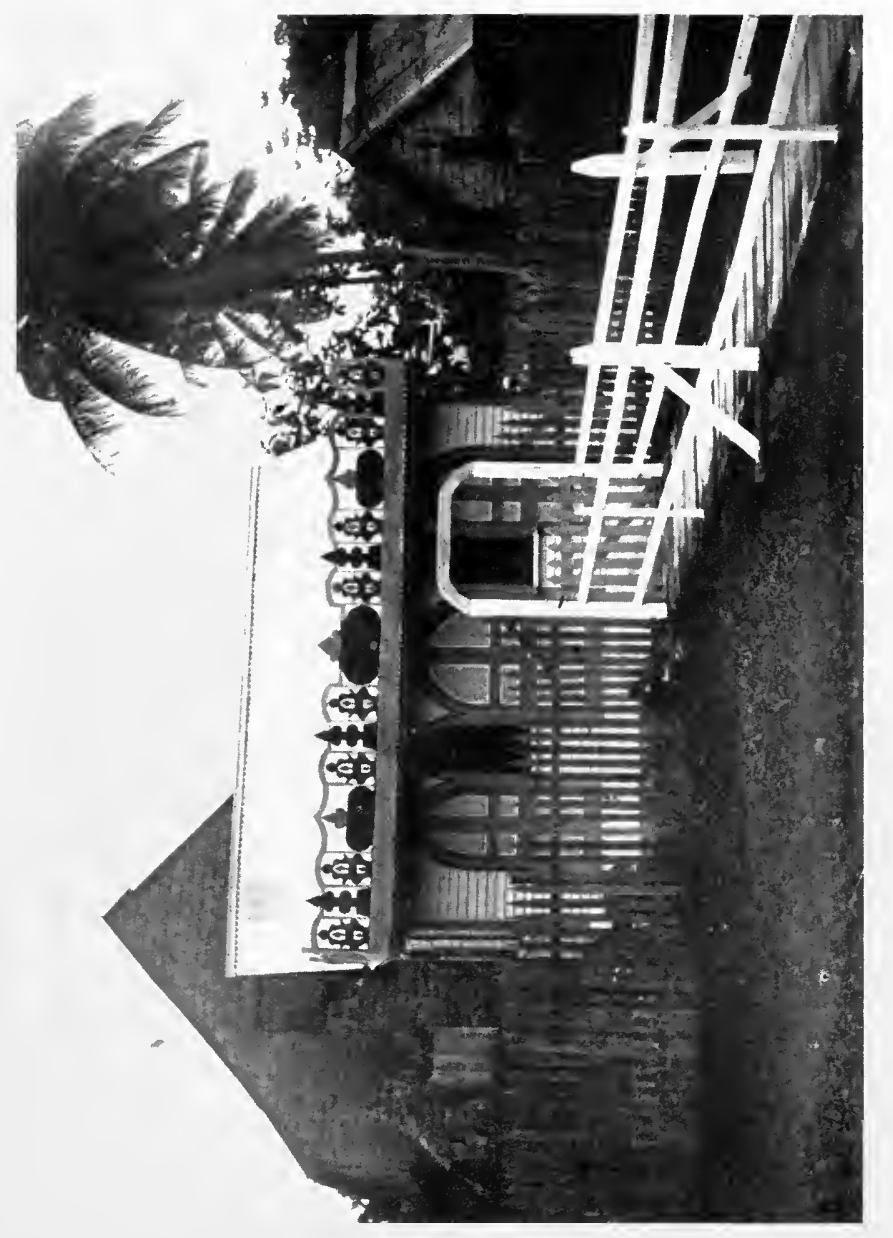

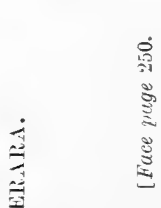



APPENDICES 



\title{
APPENDIX A
}

\section{CIRCULARS AND REPORTS RELATING TO ANKYLO- S'TOMIASIS IN BRITISH GUIANA AND IN THE WEST INDIES}

\section{Circular issued by the Surgeon-General.}

\author{
Surgeon-General's Office, \\ Georgetown, \\ 14 th December 1901.
}

SIR,

The existence of ankylostomiasis in this colony was first brought prominently to the notice of Government medical officers by the late Surgeon-General (Dr Grieve) in a Circular Letter, No. 14, dated the 2nd February 1888.

2. Since then it has been proved that the disease exists in every part of the colony, and is extending to an alarming extent.

3. The mortality returns directly attributable to this disease are small, but it is open to grave doubts whether some deaths at present attributed to other diseases would not be more correctly returned as due to ankylostomiasis. Whether this be so or not, of one point I think we may be sure, and that is: the existence of this disease is the source of the loss of a considerable amount of labour on sugar estates; hence it is most important for the employers of labour that these cases be correctly diagnosed and treated in the early stages; they could then be rapidly restored to health and become useful labourers, whereas, if neglected, they steadily become more and more debilitated, and ultimately become hopeless invalids fit only for the Alms House. 
4. As the disease is a preventable one, and eminently curable when treated in the early stages, it is our bounden duty to do everything in our power, not only to cure individual cases, but to endeavour by all means to stamp it out.

5. With this in view, therefore, I take the opportunity of bringing the matter again before your notice and of asking your hearty co-operation.

In order to facilitate the work, I beg to make the following suggestions :-

(a) The chief indication of ankylostomiasis is anæmia, with its attendant symptoms.

(b) After the removal of the parasites, this anæmia usually disappears rapidly, even without further treatment.

(c) To diagnose ankylostomiasis with accuracy, especially in its early stages, it is necessary to make a microscopic examination of the stools, in order to search for the ova. This is a most simple matter, requiring only an ordinary student's microscope with a magnifying power of not more than 150 to 200 diameters. The dispensers at the estates hospitals can easily be taught to prepare and have in readiness for you specimens of fæces of suspected cases.

(d) This is quickly done by placing a very small quantity of fæces on a slide, adding a little water if required, dropping the cover-glass on it and gently pressing it down. A ring of vaseline may then, if necessary, be put round the cover glass to prevent evaporation.

( $\epsilon$ ) Having found the ova (an excellent plate description of it is to be found in Davidson's work, Diseases of Warm Climates), the next step is to expel the parasite, and the following is the usual course adopted :-

Place the patient for a couple of days or so on "milk" or "spoon" diet, giving an alkaline bitter mixture to remove mucus. T'ien the night before the thymol is given, a dose of calomel is administered, 
and on the following morning 60 to 75 grains of thymol, divided into three doses-say, at 6 A.M., 7 A.M., and 8 A.M., and followed at noon by a full dose of castor oil. Thymol is best given in cachets or wafer papers.

$(f)$ All stools passed for 48 hours after administration of thymol should be carefully washed through muslin. This is done as follows: A good-sized hoop is made (a hoop from a flour barrel answers admirably), and muslin or very fine netting stretched over it. The fæces are then placed on this, which is held over a bucket and a stream of water kept gently flowing on them until practically all the fæces are washed away, when the worms are easily found and counted. This process can with a little teaching be done by the dispenser.

(g) The patient should then be placed on tonic treatment, and at the end of a week or so the stools again examined, and, if ova are found, the thymol treatment repeated.

6. As it has been found from experience that new immigrants frequently bring this clisease with them, or acquire it very shortly after landing here, particular care should be taken to examine each at the monthly inspections for symptoms of this disease, and any found to be suffering from anæmia should be at once placed under observation.

7. It will be noticed that the apparatus necessary for the detection of these parasites and their ova is extremely simple, the principal and most expensive item being a microscope with the necessary glass slides and cover-glasses. I therefore appeal to the estates authorities for their assistance and co-operation. This can best be given by supplying each hospital with a microscope, the cost of which should not exceed thirty dollars. I shall be pleased at any time to recommend or advise as to the sort of microscope that would be suitable.-I have, \&c.,

J. E. Godfrey, Acting Surgeon-Giencral. 


\section{Circular to all Government Medical Officers and Managers and Attorneys of Sugar Estates.}

\section{Surgeon-General's Office, Georgetown, 9th May 1902.}

\section{Ankylostomiasis.}

II. Monthly return of cases treated for Intestinal Parasites.

SIR,

Referring to my Circular No. 240, dated the 14 th December 1901, I have the honour to attach for your guidance a "form," which is to be regularly filled up and transmitted to me at the end of each month.

2. In making the microscopic examination of the fæces, you will take particular care to search for the ova of the three most common species of nematode worms found in the colony, viz., Ascaris lumbricoides, Trichocephalus dispar, Ankylostomum duodenale.

3. A description of this will be found in Manson's book on tropical diseases.

4. With regard to the purgative to be used in the ease of ankylostomiasis, it has been found advisable to use salines instead of oil, as thymol is to a certain extent soluble in oils, and toxic symptoms might follow due to absorption; for the same reason alcohol should on no account be given during the thymol treatment.

5. It is essential, in order to have the number of cases of ankylostomiasis properly returned, that every case should be diagnosed; and I must again impress on you the necessity of examining the stools of all cases of anæmia.

6. It is well to remember that in the cases of Ankylostomum duodcnale the stools should be examined shortly after they have been passed, otherwise the ova develop rapidly, and, the embryo having quitted the shell, the egg is no longer visible. 
7. With regard to the form under the heading "Result of Microscopic Examination," you will state the variety of ova of nematode worm found ; if none, enter " nil."

8. The fæces should be washed to search for the mature worms from time to time, and the result entered in the proper column.

9. Under the heading "Remarks," give anything of interest.

I have, \&c.,

J. E. GODFREY,

Acting Surgeon-General.

\section{Examination of Newly Allotted Immigrants for Ankylostomes.}

SIR,

I have the honour to direct that in future you will make a microscopic examination of the stools of every newly allotted immigrant on his or her arrival on the estate, so as to ascertain the presence or otherwise of ankylostomes.

2. This examination should be carried out with despatch, and in batches, so as to cause as little inconvenience as possible to the estates.

3. You will send the results of your examinations to me.

4. Please acknowledge receipt, and file.

I have the honour to be, Sir,

Your obedient Servant,

J. E. Godfrey, Surgeon-General.

To all District Government Medical Officers. 


\section{Circular No. 2708-British Guiana.}

\section{Government Secretary's Office, Georgetown, Demerara, 24th July 1908.}

SIR,

I am directed by the Governor to inform you that in connection with the efforts which have been made by the Government to stamp out ankylostome infection among East Indian immigrants, it has been found that upon those sugar estates where suitable latrine accommodation has been provided, and where efforts have been made to prevent the resident population from defecating elsewhere, there has been a marked improvement in health conditions.

2. The Secretary of State for the Colonies has, under the circumstances, suggested for consideration that in order to make these arrangements universal, and thus to lessen the risk of ankylostome infection to the general labouring population of the colony, the allotment of new immigrants to an estate should be dependent upon its being made clear that proper latrine accommodation has been provided.

3. The matter has been considered by the Governor in Council, and I am to inform you that having regard to the importance of combating ankylostome infection, it was considered very desirable that the suggestion should be adopted. I am therefore to inform you that, while no immediate action will be taken to give effect to it, as the allotment of immigrants during the current year has already been approved, the question will necessarily come before the Governor in Council when the applications for next year's allotments are received, and His Excellency trusts that if you should apply for immigrants next year you will be in a position to state that suitable latrine accommodation has been provided.

I have the honour to be,

Sir,

Your obedient Servant,

Charles T. Cox, Government Secretary.

To Kinployers of Coolie Labour. 
Sir,

Your attention has several times ${ }^{1}$ been called to the prevalence of anæmia among the labourers (indentured immigrants and others) employed on the sugar estates, and in the circulars noted in the footnote special reference has been made to ankylostomiasis as the principal cause of it.

2. The Governor, who has had this matter under his attention, is glad to notice that in the case of some districts the medical officers have carefully carried out their instructions for discovering and treating ankylostoma infection. But in others, although the conditions are more or less identical, nothing, or practically nothing, has been done.

3. The loss of work on estates due to anæmic labourers is at times very severely felt, and I am to acquaint you that His Excellency is determined that every possible effort shall be made to prevent any further loss of labour from ankylostoma infection or any other preventable cause. He expects that every Government medical officer will co-operate in the work of stamping out, or at any rate reducing, diseases of that character, and he trusts that henceforward those medical officers who have not hitherto attached importance to the disease of ankylostomiasis will do so in future, and that it will not be necessary to send further circulars and reminders.

4. The Governor's direction is that every immigrant, whether free or indentured, and every labourer who may be brought before you suffering from anæmia or showing any symptoms suggestive of the presence of ankylostomes, shall be dealt with in accordance with the instructions in your hands; and he desires it to be known that any officer who disregards this plain direction, will incur grave responsibility as regards the health of the labouring population, and, incidentally, the consequences which result from neglect to carry out an official order.

1 No. 14, of 2nd Feb. 1888 ; No. 240, of 14th Dec. 1901 ; No. 249, of 9th May 1902 ; No. 345, of 8th July 1904 ; No. 357, of 26th Oct. 1904. 
5. It will, I am to add, be one of the duties of the medical inspector to see that these orders are henceforward carefully observed and to make a report to me when there has been failure, which report will, in every instance, be submitted to the Governor.

$$
\text { I am, Sir, }
$$

Your obedient Servant,

J. E. GoDFrey,

5th November 1904. Surgeon-General, Georgetown.

N.B.-Please acknowledge receipt, and file.

To all Government Medical Officers.

Correspondence with regard to the prevention of Ankylostomiasis in British Guiana and other Colonies, 1909.

Summary of the Reports Received from the West Indian Colonies on the Subject of Ankylostomiasis.

Bahamas.-In this colony the disease is said to be practically unknown.

Bermuda.-This colony is also said to be free.

British Guiana.-The disease is very prevalent, no less than 39,000 cases having been treated in the estates hospitals in the last four years. There are no special sanitary measures legally enforceable for dealing with the disease. The Medical Department have had to rely on persuasive measures; but much has been done, especially on the sugar estates, 23 of which, or nearly 50 per cent., have been induced to provide proper latrine accommodation for labourers. In the village and country districts, the latrine accommodation is very unsatisfactory; but in the opinion of the Surgeon-General, the matter is not so important there as on the sugar estates. The village councils, under the guidance of the Local Government Board, are making every effort to improve the sanitary condition generally, so far as their finances 
allow. The Surgeon-General has recommended the enactment of legislation to compel owners to provide proper accommodation on estates; but the Governor wishes to postpone action, in view of the precarious financial condition of the estates. The Secretary of State has suggested to him that it might in any case be possible to make the allotment of new indentured labourers to an estate conditional on the provision of satisfactory sanitary arrangements. ${ }^{1}$ The treatment of individuals with thymol, beta-naphthol, or eucalyptus appears to be well understood, medical officers using one or other of these drugs according to individual preference.

Jamaico.-Ankylostomiasis is prevalent in certain districts, especially among the Indian labourers. No sanitary measures have been enforced on estates. A circular advocating the provision of latrine accommodation was sent to estate owners some years ago; but although something was done on a few estates, there was a difficulty in compelling the coolies to use the latrines, and no serious effort was made by employers to carry out the suggestion of the Government. Treatment with thymol appears to be general in Jamaica. The Governor proposes to consider amendments of the law to give the Medical and Immigration Departments power to enforce sanitary regulations. The general opinion of the medical officers is that the treatment of the population en masse is impracticable, and stress is mainly laid on sanitary measures. Notification of cases is recommended. The conditions in the villages seem to be fairly satisfactory.

Leeward Islands. - Ankylostomiasis is not prevalent, except, perhaps, in Antigua. No sanitary measures are enforced. No special measures are considered necessary, beyond the erection of additional latrines in centres of population. Individual cases have been treated with thymol.

Trinidad.-No special report has been received. The Factory Ordinance, now under consideration, contains a clause enforcing

1 The Governor has now issued a circular to estate owners, warning them that the allotment of immigrants in future years may be made conditional on the provision of suitable latrine accommodation. 
the provision and use of suitable sanitary accommodation, wherever groups of ten or more persons are employed on a sugar estate, the accommodation to be within 100 yards of the place where the persons are employed, and imposes a penalty on the misuse of such accommodation.

Windward Islands.-It is estimated that two-thirds of the labouring population in St Vincent are infected. No sanitary measures are in force, and no latrine accommodation exists on estates, while that in the villages is inadequate. The Administrator of St Vincent expresses the opinion that no successful campaign against ankylostomiasis is possible without a much more numerous and efficient medical staff. The medical officer of Kingstown suggests, besides the usual sanitary measures, the supply of drugs and microscopes to medical officers. In St Lucia the disease is very prevalent. The Administrator thinks that the Board of Health have powers to enforce sanitary measures at all factories and estates: but for this purpose funds would be required for inspection. No sanitary measures are, in fact, in force, and no latrine accommodation exists on estates. The villages are better provided in this respect. The medical officers regard treatment en masse as impossible. They recommend the instruction of the school children in simple sanitary rules. The Administrator suggested that some part of the cost of treatment of labourers should be thrown on employers, but the Governor appeared to think this impracticable. In Grenada ankylostomiasis has not reached very serious proportions. The Governor doubts the efficacy of any sanitary measures, since the labourers are not employed in large numbers on estates, and are constantly moving from place to place, being consequently very difficult to control in sanitary matters. Something might be done by persistent teaching in the schools : but he was not optimistic. The Secretary of State drew the Governor's attention to the allegation that the schools were not provided with adequate latrines, and asked that the matter might be looked into.

14 th October 1908.

Note.-Since the above memorandum was written, a dispatch has been received from the officer administering the government 
of Trinidad, from which it appears that the legislature will shortly be invited to deal with the question of sanitary accommodation on estates and in the largest centres of population. The SurgeonGeneral has arranged with the majority of estates proprietors to provide at their hospitals small microscopes and other apparatus. 


\section{APPENDIX B}

\section{REPOR'TS RELA'IING 'TO MOSQUI'TO-CARRIED DISEASES IN ST LUCIA}

Being the Replies to the Circular LetTer of the AdminisTRATOR asking For a RETURN OF MOSquito-borne Disrases in the Island, also on the Prevention of Tropical AN EMIA.

\section{D) Hughes to the Administrator. \\ Dennery Hospital, 6th December 1905.}

SIR,

In reply to your circular letter of the 25th November 1905, I have the honour to forward a return showing number and description of mosquito-borne diseases in the district during the last twelve months.

The number coming under my notice as a private practitioner extend only over a period of five months, as I took charge of this district on 4th July 1905.-I have, etc.,

A. F. Hughes.

Return of Mosquito-borne Diseases for the Fourth District for the past Twelve Months.

Diseases.

Number.

Remarks.

Malarial Fever.

Quotidian

Intermittent.

Tertian

158

Irregular

2

Bilious.

Remittent . . 1 Private practice.

Pernicious.

2. Filaria.

Elephantiasis . 1

Total . 162

The majority of these are females below 25 years. 


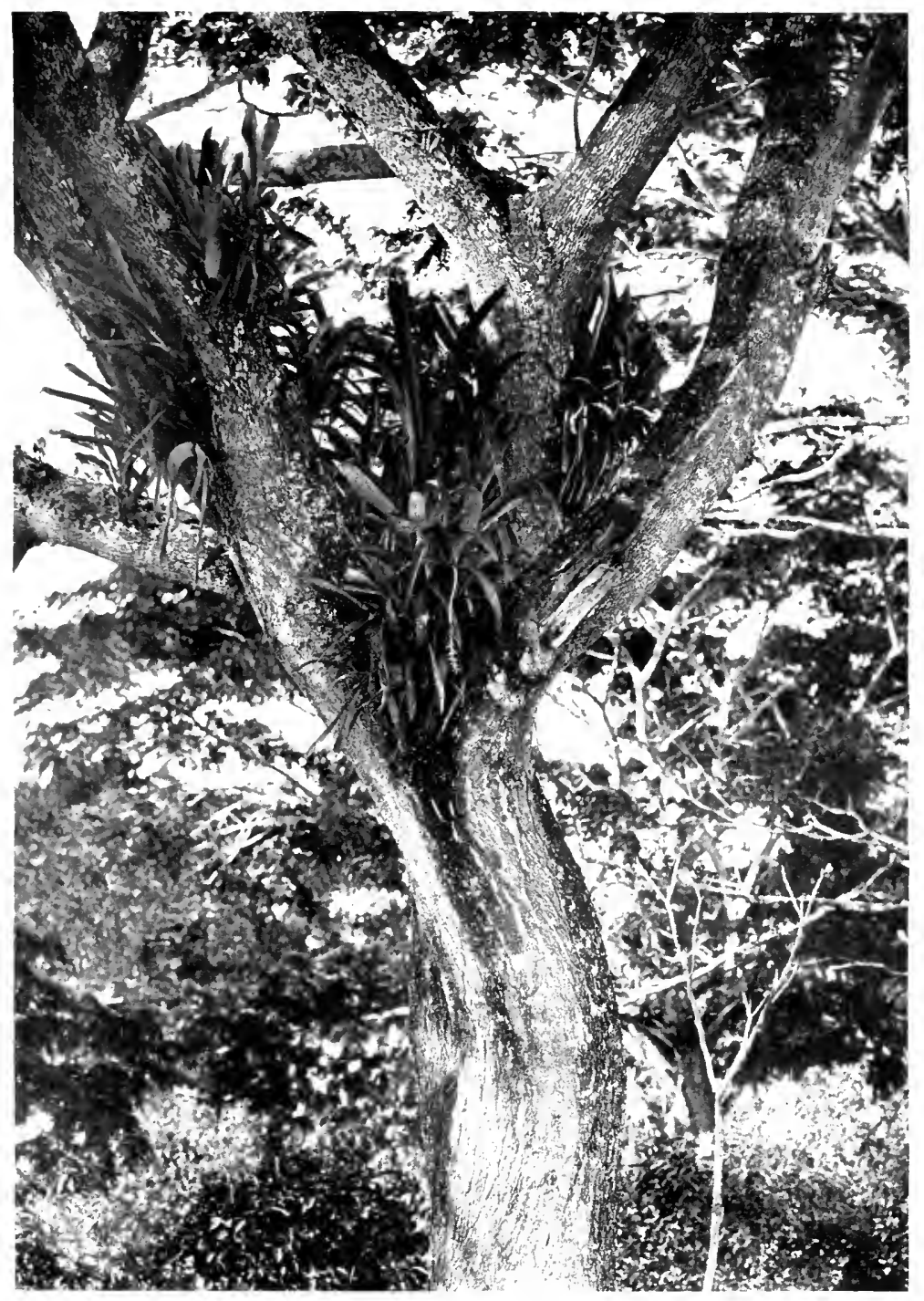

FIG, 45.-WATER-HOLDING IND MOSULTTO-LREEIING: EPIDHYTES

UPON A TREE, TRIXIIAD. 



\section{Dr King to the Administrator.}

CAstries, 16th December 1905.

SIR,

In reply to your circular of $25 \mathrm{th}$. November regarding mosquito-borne disease, I beg to submit the following figures:-

Month.

December 1904 . January 1905

February 1905 .

March 1905

April 1905

May 1905

June 1905

July 1905

August 190

September 1905

October 1905

November 1905

Total
Cases.

16

19

12

18

39

51

13

18

20

18

22

40

2. Of other preventable diseases, the intestinal parasites are the most important. In my opinion, these parasites cause far more serious illness and more deaths than do the mosquito-borne diseases in this colony. To them is largely due the large infantile mortality here.

In the towns it is the Ascaris lumbricoides which is most prevalent, and nothing but cleanly habits among the people can prevent persons becoming infected.

In the country there are places which are infected by Ankylostomum duodenale to such an extent, that even were rigorous measures enforced, these places would continue infective for a long time. It is noticeable that the places where the villages are worst kept and dirtiest, and where the people are filthiest in their habits (Roseau) give the largest number of cases. 
Another preventable disease which appears to be on the increase is enteric fever, but cases are very few and far between, and I have never been able to trace the origin of any case.

Infantile diarrhœa is not often prevalent, but much might be done to prevent it.

$$
\text { I have, etc., }
$$

ALEX. KING.

\section{Copy of a Circular on the Prevention of Ankylostomum Ancemia.-St Lucia.}

The disease which usually gives the people "palpitation" or "beating of the heart," "giddiness," "shortness of breath," and sometimes "sour stomach," is very often caused by a kind of worm, and can be prevented.

The worm (which is very small) lives in a person's bowels, and the eggs pass when the bowels move. In wet earth the eggs are hatched to very small worms--too small to be seenwhich enter the skin of the feet of anyone who walks on the soiled earth, or enter by the mouth of a person who eats with fingers which have touched the soiled earth. They reach the bowels, suck blood from them, and cause sickness.

If a person who has the sickness eases his bowels where others may walk, he may spread the disease. Many people who do not feel very sick have these worms, so nobody should ease his bowels in a place where other people may walk.

To prevent this disease:

1. Always wear boots if you can.

2. Never eat without first washing your hands; never let your children eat without first washing their hands.

3. Never ease your bowels where any person may walk; always use a latrine or buckets when possible.

4. Be careful with latrine buckets. Empty them at the proper place; never spill them in the street.

5. Train your children carefully in these matters. Never 


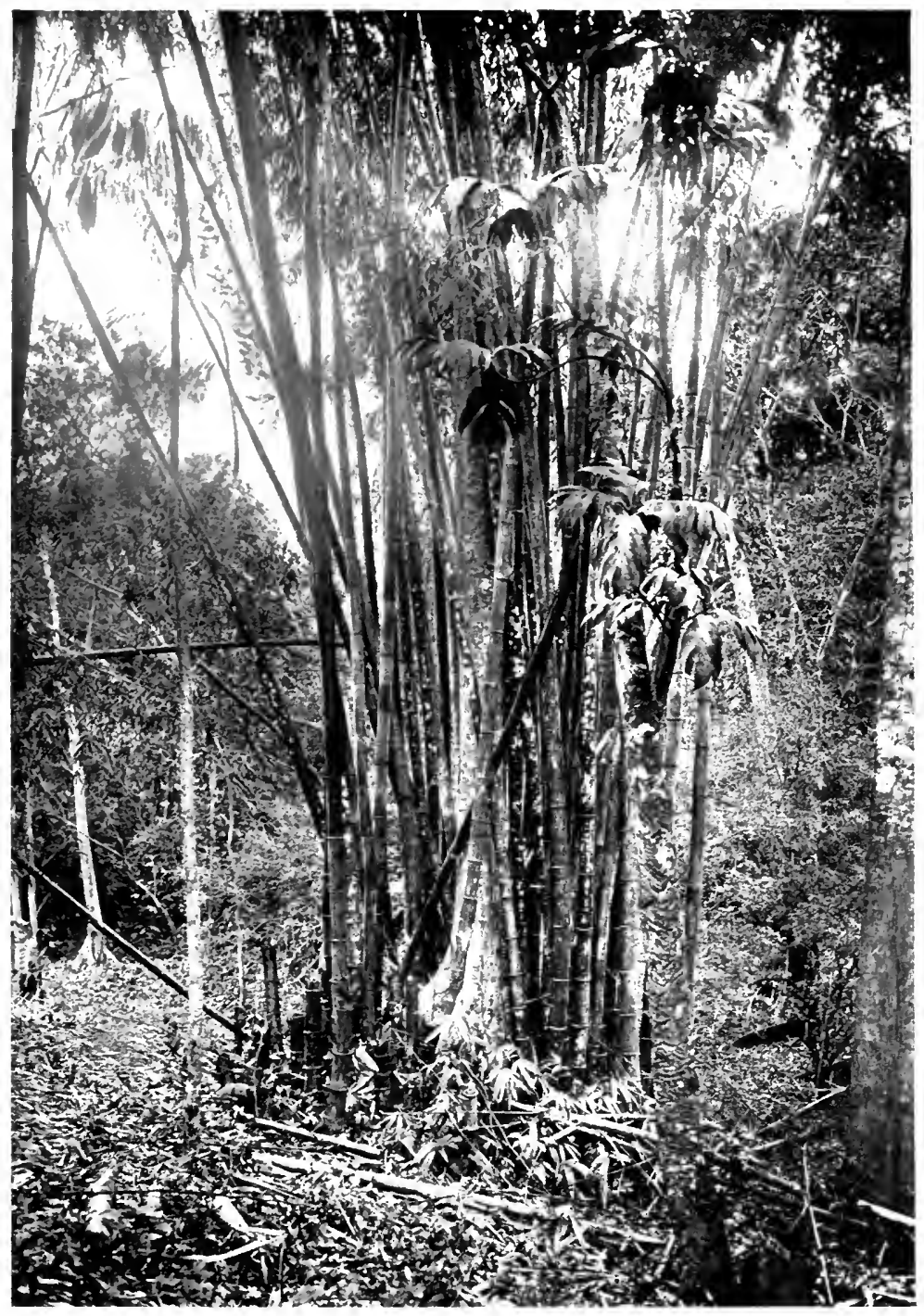

FH: 4\%.THE B.A.HBOO. 
1 
let them ease their bowels about the yards of the houses. Children often have the disease.

6. All excreta should be buried at least six inches below the ground. If this is done no harm can follow.

These instructions are for your own benefit, to prevent you falling sick from this disease. 


\section{APPENDIX C}

\section{CIRCULARS ISSUED BY 'THE HEALTH AUTHORITIES OF BARBADOS UPON THE SUBJECT OF YELLOW FEVER AND MOSQUITO DES'TRUC'TION}

\section{Upon the necessity of Prompt Screening and Mosquito Destruction.}

In reference to my circular of the 29th December last, in respect to the carrying out of the yellow fever regulations, I have been directed to ask that your board will, if they have not already done so, at once procure and have ready for immediate use, and have replenished as same wears out, as much mosquito netting as will effectively screen six patients, and will arrange that on a case of yellow fever being notified to your inspector the patient shall be screened, so as to prevent mosquitos from spreading the infection; and will also at the same time take steps under Regulation 4 to destroy the mosquitos, as well in the infected house as in any neighbouring houses which the doctor may think necessary, and in pools round about the houses; and will keep under observation for eighteen days all "contacts" of the patient, and from the twelfth to the eighteenth day will have such contacts examined daily by a medical man.

As it is highly desirable in the interests of the public health that any case of the disease occurring should be dealt with with as little delay and as effectively as practicable, I am directed to express the hope that your board will do everything possible to deal promptly and effectively with any case which may occur in your parish; and in order to assist you in doing so, my board will be willing to receive at Pelican Island any first cases, not 
exceeding four, which your board may not be able to deal with effectively at their homes.

4th January 1909.

Jas. SANDERSON, Clerk, General Board of Health.

The Chairman, Commissioners of Health.

Orders made under section 8 of the Public Health Act of 1898.

Importance of Suspicious Cases and Prevention of Wakes.

1. Immediately on the inspector of health of a parish being satisfied of the existence of a case or suspicious case of yellow fever in the parish, he shall at once affix to a conspicuous part of the house in which the sick person is, a "poster" with these orders printed thereon.

2. After such poster shall have been so affixed, no persons other than those persons actually residing in the house or in immediate attendance on the sick person, or who may be authorised by the medical attendant, shall enter such house until such house has been effectively fumigated.

3. Where any death occurs from yellow fever, no assemblage of persons in or about the house where the death occurs, and no "waking of the dead" shall take place.

4. The three foregoing orders shall for the present be limited and apply only to the parish of St Lucy.

Made by the General Board of Health, this 12th day of January 1909.

W. K. ChANDLER,

President.

14th January 1909.

As I have elsewhere stated, in the absence of a principal medical officer of health, and yellow fever still continuing to be notified in the parishes, the board of health requested one of 
their number to make a survey and to report upon the situation. Dr Hutson, the gentleman deputed, reported as follows: ${ }^{1}$

SIR,

HARMoNy HaLL, 9th January 1909.

At the request of your board, conveyed in your letter of the 5th inst., I visited the parish of St Lucy on Thursday, the 7th inst., in order to enquire into the situation with regard to the outbreak of yellow fever reported from that parish.

(c) With regard to suggestions for dealing with the existing situation, I found that all the most important necessary measures had already been decided on, although nothing had actually been done, owing to the uncertainty of obtaining the necessary funds.

The chairman of the sanitary commissioners handed me the following list of measures decided on by the sanitary board at a special meeting on 29 th December, which had been communicated by him to the President of the Board of Health. I quote his written memorandum :-

1. Isolation hospital.

2. A daily house-to-house inspection, with a view to report instantly to the parochial medical officer all cases of sickness. Six or eight inspectors may be necessary.

3. The parochial medical officer to attend such cases without any delay, with the view of removing the patient to the isolation hospital, if practicable, and also contacts.

4. All houses that contain yellow fever patients to be placarded, forbidding all people entering.

5. All expenses incurred to be borne by the Government.

In your letter to the Chairman of the Sanitary Commissioners, forwarded to him by me on Thursday, all these measures were

${ }^{1}$ I have omitted details of visits, etc. 
insisted on except the placarding of houses, which in my opinion would be a useful measure. The chairman points out, however, that this would be useless unless enforced by some policemen in uniform, as the ordinary rural constable has not sufficient authority to enforce measures of this kind. It appears that the fatal results of so many cases have caused an immense sensation in the district, and people and friends in the neighbourhood crowd into infected houses to visit the sick and in some cases spend the night there. The medical officer informed me that he counted eleven persons come out of a room where a yellow fever patient was lying ill, although he had given instructions that no one was to visit the house. When I visited the man Johnson, who was dying of yellow fever, there were quite a dozen persons in the room and at the door of the house. Of the fatal cases, Rollock was a visitor at Bowen's house and Johnson at Rollock's house.

6. The question of contacts has been dealt with by the Board of Health and a daily inspection by sub-inspectors has been ordered, followed by a medical inspection from the twelfth to the eighteenth day after the isolation of the case with which they have been in contact.

The Chairman of the Sanitary Commissioners and the medical officer are of opinion that this medical inspection is impracticable unless these persons are forced to remain at home or are made to go to some central place and be kept there.

This is a serious difficulty that must be considered by the Board of Health.

I think the number of contacts will be much reduced by preventing visitors to an infected house, and the actual inhabitants of the house will generally be available for inspection when the medical officer visits.

I suggest that the Board of Health pass an order, under section 8 of the Public Health Act, 1898, that infected houses should be placarded and visitors not allowed.

7. Another important matter is the prevention of "wakes," as provided for in No. 23 of the cholera rules made in 1893, in the case of that disease. This provision should be extended to all the quarantinable diseases. I am led to suggest this because I was informed that in one of these cases at least a wake was actually 
held. A collection of persons at night in a house where infected mosquitos are likely to be is specially dangerous in the presence of yellow fever. This provision would only be necessary if the previous suggestion I have made is not carried out. If visitors are excluded, wakes will not take place, except they are carried on by the family in the house-an unlikely event in any case.

8. It will be necessary to provide one or more houses in the district, to which persons can be moved after isolation of a patient while disinfection is being carried out. This is necessary if disinfection is done after dark, as it should be, in order to destroy as many mosquitos as possible, and especially the mosquitos that are active after sunset.

9. The most important measure, and one which should be most thoroughly and carefully done, is the destruction of mosquitos by treating with kerosene oil, Jeyes' fluid, or white lime all water-holes and collections of water in hollows or in privy-pits. In short, the breeding places of mosquitos must be attacked and abolished by drainage as far as possible, and where this is not possible the water must be treated in order to destroy mosquito larvæ. One man at least should devote his whole time to this small district, and his work should be carefully supervised by the medical officer and the sanitary inspector when they are visiting the district daily.

The destruction of mosquitos has already been suggested in the letter of your Board to the chairman, and I specially impressed on him the necessity for this measure, and urged that it should be commenced on Thursday at once.

10. It will be necessary to deal with all suspicious cases as if they were yellow fever, and not wait for positive symptoms to develop before screening and isolation are carried out; mosquito netting has already been provided. An attempt had been made to screen one of the patients I visited. The attempt did not reflect much credit on the inspector who had carried it out.

The control of the disease by preventing access of mosquitos to patients, is almost impossible in an isolated country district where the people are accustomed to wait some days after an illness commences beforc calling the doctor; but the daily house-to- 
house inspection will do much to discover new cases in the early stage. More reliance must be placed on the general destruction of mosquitos by destroying their breeding places, and on the special destruction of infected mosquitos by fumigation.

To recapitulate,-

The necessary measures are, as already described,-

1. The general destruction of mosquitos and the special destruction of mosquitos in infected houses.

2. The provision of an isolation hospital for the treatment of all suspected cases.

3. A daily house-to-house visitation in the infected district, with inspection of contacts, and medical inspection of contacts after the twelfth day.

4. Immediate report to the medical officer of all cases of illness in the district.

5. The appointment of inspectors for the daily inspection and patrol of the district.

All these have already been done or are arranged for as soon as it is possible to start them.

The following additional measures are recommended:-

6. The control of contacts by placarding of houses and restriction of visitors. For this purpose a special order would have to be made by the Board of Health under section 8 of the Public Health Act.

7. The prevention of wakes by order.

8. The provision of temporary accommodation for contacts while infected houses are being fumigated.

9. The effective control of all suspicious cases before the complete development of the disease.

The condition of the standpipes in Pio Corner and the need of a special squad of police have been referred to in previous pages. I further reconmend that a permanent infectious diseases hospital be arranged for in St Lucy, seeing that since 1902 this is 
the third time that provision has been made for meeting an epidemic, and each time the special equipment is disposed of.

With regard to what has actually been done, the Chairman of the Board arranged to summon a meeting of the Sanitary Commissioners for Saturday (yesterday), at which Durham Schoolhouse would be appointed for the use of the almshouse inmates, so that the almshouse may be used as an isolation hospital. Subinspectors were appointed by the chairman immediately after my visit, as he had names ready for appointment.

Special attention was to be directed to the destruction of mosquitos in water-holes, and a supply of mosquito netting for the hospital was arranged for through yourself as Clerk of the Board of Health after my return from St Lucy, as well as additional supplies of sulphur and Jeyes' fluid. At Dr Massiah's suggestion I have engaged two nurses in readiness to go down when he notifies he is ready for them.

The great length of this report prevents reference to many points of interest connected with the origin of the outbreak and the methods of notification, as well as the difficulties met with in getting hold of the early cases of the disease; but I have tried to confine myself to the actual points referred to in your letter of the 6 th inst.

\section{Circular upon importance of immediate Isolation, Screening, and careful Fumigation.}

1. In reference to my circular of the 4th January last, I have been directed to say that the screening of any person suffering from yellow fever, or a fever suspected to be yellow fever, may be done either by a netting put over the patient's bed or by mosquito (netting) frames made to fit over the doors and windows of the room in which the patient is, so as to prevent mosquitos getting into it.

2. I have been further directed to say, that the question having been raised at a meeting of the Board yesterday, as to whether it was necessary that the fumigation of infected houses should be done under the supervision of a medical man, the Board were of upinion 
that if, or when the Commissioners of Health for a parish are satisfied that their inspector is competent to carry out such fumigation, such fumigation need not be supervised by a medical mau.

3. The question as to whether a person who is suffering from yellow fever, or a fever suspected to be yellow fever, and cannot be effectively isolated on their own premises, but refuses to be removed to an isolation hospital, can be forcibly removed to such hospital, was brought before the Board of Health yesterday, and I was directed to say, for your information, that if such a person has been duly certified by a medical man to be suffering from yellow fever, or a fever suspected to be yellow fever, the police would be authorised, without any further warrant than the doctor's certificate, to enter the house of such person, after demanding admittance thereto, even by breaking into it, and remove the person to the isolation hospital; but if such medical certificate has not or cannot be obtained, then the sick person cannot be removed.

4. Should it happen that any ill person in your parish should refuse to be seen by a medical man, so as to enable him to give the necessary certificate, and such person cannot be induced to see the medical man, then the fact should be notified to me, so that the Board may deal with the matter.

5. The Board of Health yesterday made a general order forbidding the assemblage of persons and the holding of "wakes" in any house where a death has occurred from yellow fever. A copy of the order is sent herewith.

JaS. SANDERSON,

4th February 1909. Clerk, General Board of Health.

Sent to Commissioners and Inspectors of Health and Parochial Medical Officers. 
Order made under section 8 of the Public Health Act, forbidding Wakes.

1. Where any death occurs from yellow fever, no assemblage of persons in or about the house where the death occurs, and no "waking of the dead," shall take place.

Made by the General Board of Health, this 3rd day of February 1909.

I approve.-G. T. CARTER,

W. K. Chandler, President.

Governor:

4th February 1909.

\section{Circular drawing attention to Tardy Notification.}

Complaints having been made by some of the colonies who are parties to the Quarantine Convention, and also by the Foreign Consuls here, as to the length of time which in many of the reported yellow fever cases had elapsed between the case being diagnosed and the receipt of the report of it by the Board of Health, I have been directed to ask, that should you have a case of that disease you will at once send me direct a notice thereof on the top memorandum of the notification form, in addition to the usual notification to the Inspector of Health.

8th February 1909.

$$
\begin{aligned}
& \text { JAS. SANDERSON, } \\
& \text { Clerk, General Board of Health. }
\end{aligned}
$$

Sent to all Medical Practitioners.

Circular upon the necessity of Increased Vigilance, and the appointment of a Central Inspector and better Sanitary Supervision of Parishes.

At a meeting of the Board of Health yesterday, it was decided to appoint a Central Inspector to inspect day by day Bridgetown 
and its suburbs and the towns and villages and rural portions of the several parishes, for the purpose of ascertaining that the sanitation thereof was being efficiently and continuously carried ont, and also to bring to the notice of the proper parochial authority, any matter which in the opinion of the inspector required looking after, and to report from time to time on his work to the Board. Mr Cumberbatch was appointed.

The Board also decided to request the Commissioners of Health of each parish, if they had not yet done so, to divide up their parish into workable districts, and to place in charge of each district one or more (according to the size of the district) sanitary inspectors, with instructions to visit daily the houses in the district and report to the Parochial Medical Officer of the parish all persons found to be ill with fever. Each inspector to report daily to the Chairman of the Commissioners the sanitary and health conditions of his district, so as to ensure prompt medical attendance on every fever patient and the efficient sanitation of the whole parish.

The Board trust that your Commissioners will comply with their request in this matter with as little delay as practicable.

The Board are recommending the Central Government to bear the cost of the measures above referred to, and have no doubt that this recommendation will be favourably received.

$$
\begin{gathered}
\text { JAS. SANDEnSON, } \\
\text { Clerk, General Board of Ilealth. }
\end{gathered}
$$

8th February 1909.

Sent to Commissioners of Health of all Parishes.

Diary of the Central Inspector, 8th to 21st February.

I have examined the diary of Central Inspector Cumberbatch; it shows that this inspector was fully alive to the importance of the duties entrusted to him. The diary commenced on 8th February. I notice that on 9 th February he draws attention to the small accumulations of water which occur round standpipes. On the 10th he states:- "Caused several barrels containing water filled with larvæ and mosquitos to be emptied, and explained to 
the occupants my reasons for so doing." He also draws attention to the following, in connection with fumigation of a case of yellow fever:- "I do not think that as much care in stopping all crevices was taken as might have been." He adds: "I explained to the people of this neighbourhood the 'Mosquito Theory,' and warned them about the water in barrels and casks, and explained "Fumigation." "

12th February. - With regard to the fumigation of another house, he states:- "This house was improperly fumigated, as it was not made tight enough before the fumigation was started." Again, four houses and a meeting-room next to this house were not fumigated.

13th February.-I caused a good amount of water with larvæ and mosquitos to be thrown away in this distriet, and explained to the people why I acted thus.

17th February.-I found many vessels containing water with larvæ and mosquitos; had them emptied, and explained to the people my reason for so doing.

18th February.-I threw away several vessels of water containing larvæ and mosquitos.

\section{Rules for dealing with cases of Yellow Fever.}

For the general guidance of medical men and sanitary inspectors, the following rules for dealing with cases of yellow fever occurring in Barbados were issued by the Board of Health on 21st January 1909 :-

1. Any person certified by a medical practitioner to be suffering from yellow fever, or a fever suspected to be yellow fever, shall as soon as possible be protected effectively at his own expense from access of mosquitos on the premises on which he then be, and be detained there until his medical attendant certifies him to be no longer capable of imparting infection to mosquitos; or if he cannot, in the opinion of his merlical attendant, be effectively 
isolated from mosquitos on such premises, shall be taken, with not more than two attendants, if such attendants desire to be taken, to some place previously appointed by the Board of Health for the reception of such cases, and there detained until he is no longer capable of imparting infection to mosquitos. Provided that no patient shall be removed unless a medical practitioner shall certify that he can be removed without endangering his life.

2. The General Board of Health or the Commissioners of Health of each parish may in their discretion send a qualified practitioner to examine the premises in which a person certified to be suffering from yellow fever, or a fever suspected to be yellow fever, is, and to report to them respectively, whether such person can be effectively protected from mosquitos on such premises; and the said Board of Health or the said Commissioner may, if they are satisfied that such person cannot be protected as aforesaid, direct his removal to the place previously appointed as aforesaid.

3. If any patient is confined to his own premises under the restrictions authorised in Rule 1, on his becoming free from infection, a certificate from his medical attendant to this effect shall be sent by him to the sanitary inspector of the district.

4. As soon as possible after a case of yellow fever is notified under section 23 of the Public Health Act, the necessary steps shall be taken by the Commissioners of Health of the parish in which the patient is lying ill, to thoroughly destroy by fumigation with sulphur or pyrethrum, by petrolisation, or otherwise, the mosquitos within or around the house and premises in which the patient is, and if necessary the mosquitos in houses or premises adjacent to the house where the patient is. In the latter case a certificate in writing shall be issued by a qualified medical practitioner appointed by the Commissioners of Health for this purpose, or, in the absence of such officer, by the medical attendant of the patient, stating in detail the houses and premises which in the opinion of the person signing such certificate should be dealt with for the destruction of mosquitos.

5. The procedure for the protection of the patient from 
mosquitos and for the destruction of mosquitos in infected houses and premises shall, as far as practicable, conform to the procedure described hereunder, viz. :-

The room occupied by the patient shall at once be closed by wire gauze. False windows and doors covered with wire gauze shall be at once adjusted to the openings in the room. The doors and other openings that may communicate with other apartments in the house shall be temporarily closed with stout paper in order to prevent the entrance of smoke into the room occupied by the patient. The rest of the house shall be fumigated if necessary. To do this, all compartments shall be carefully closed. Strips of paper shall be pasted over all cracks. Open spaces in houses shall be closed with screens of stout paper.

After the fumigation of the rest of the house, the patient shall be transferred to one of the fumigated rooms, previously closed with wire gauze, and the sick chamber shall then be disinfected in the manner hereinbefore prescribed. Neighbouring houses certified under Rule 4 shall be treated in the same way.

Petroleum shall be poured into all receptacles where mosquito larvæ may grow.

Fumigation by sulphur is recommended, and should be used in the proportion of $3 \mathrm{lbs}$. for every 1000 cubic feet of airspace.

The routine of disinfection as used in Havana is as follows, namely:-The inspector assigns one man to each of the windows or openings in the room. The duty of each man is to close the openings perfectly by pasting strips of paper over all cracks and joints. While this is being done, the inspector has measured the eubic space of the room. If possible, an opening is left somewhere for the admission of light; it may be a glass pane or an opening covered with paper. On the window-sill or floor below this opening a sheet of moistened white paper is placed. It las been found that the mosquitos, during the fumigation, flock toward this opening, and when paralysed by the smoke they are apt to fall upon the paper below, where they can be more easily gathered afterwards. The sulphur or pyrethrum powder is now placed in pans and ignited by setting fire to a small amount of alcohol in each pan. One door has been left open for exit of the men. Before ?eaving, all clothing is shaken and scattered about the room. 
The exit door is now closed from the outside; its joints and cracks are pasted over.

Pyrethrum is burned in the proportion of $1 \mathrm{lb}$. to every 1000 cubic feet of space.

At the expiration of four hours the door is partially opened to allow the men to enter. The walls, ceiling, and floor are carefully swept, and the clothing is once more shaken. Any mosquitos found to be still living are thrown into the pans.

Before leaving the house, a certificate should be obtained from the family to the effect that no damage has been done to the property in the process of disinfection, or if otherwise, a note is taken of complaints that may be made.

\section{Hints upon Treatment of Yellow Fever, based upon those practised by $\mathrm{Dr}$ Guiteras of Havana.}

The statistics of the mortality in our hospital show the importance of early treatment in yellow fever: not that we have any specific that must be applied at the beginning of the attack, but that rest in bed constitutes an important factor in the treatment.

Excepting the administration of a laxative and the employment of some palliative measure, nothing else has been done here in the first 48 hours, or even through the whole attack in mild cases where there was no special indication.

Our treatment here is published in detail in an article by Major Gorgas, U.S.A., in the Journal of the Association of Military Surgeons for October 1903.

We put the patient to bed at once and make him keep the horizontal position. Clean linen for the bed and person should be furnished plentifully. Windows and doors are kept open (mosquito-screened), only avoiding direct draughts. Quarters should be very clean. Patients seem to do best when treated in tents or newly constructed frame buildings.

The skin is cleansed and rubbed with hot water and soap on admission. It is not unreasonable to suppose that these measures 
may lessen the chances of secondary infections, which may be the cause of the hremorrhagic manifestations.

Water is given freely through a drinking-tube. From 50 to 80 ounces of fluid are given in the 24 hours. Pleasant alkaline waters and infusions and ginger ale are given. The patient is not allowed to sit up to empty bladder or rectum.

Something is done at the same time to relieve suffering and gain the confidence of the patient. External applications: sinapisms, ice, liniments. If the temperature be very high the surface is sponged with cool water and alcohol, or an enema of cold water is given.

Phenacetin may be given to relieve pain at night, if necessary once or twice, but should not be insisted upon.

The first symptom that is likely to call for special treatment is vomiting. If the bowels have not acted since the initial purge, Seidlitz powder in broken doses to mix in the stomach, or minute doses of calomel or effervescent magnesia, is given. If the vomiting is persistent, the administration of liquids by the mouth is discontinued, and only cracked ice is given, and rectal injections of warm physiologic salt solution. If the rectum has not been irritated by frequent purgation this can be kept up with advantage. Milk may be added later.

Cocaine tablets and ice applied to the throat are used with advantage in vomiting.

When black specks appear in the vomit, tincture of the chloride of iron, 5 gtt. every 2 or 3 hours, is usually given, with a little glycerine and lemon juice. For hæmorrhage from the mouth an antipyrine wash is used.

The remainder of the treatment reduces itself to sustaining the strength of the patient and stimulating the action of the heart and kidneys by the judicious use of strychnia, digitalis, and alcohol: the two former by the hypodermic method and the latter by the mouth or rectum. Alcohol is not well borne in large doses. The same may be said of strychnia. Champagne is the best form of alcohol.

Cold-water rectal injections and calomel as a diuretic are tried in suppression of urine.

The prolonged typhoid cases, often marked by pronounced jaundice, require alcohol and strychnia. Chlorate of potash is 
given with apparent advantage. In convalesence, muriatic acid and nux vomica.

Feeding with milk and lime-water is commenced on the third, fourth, or fifth day. The quantity of milk is gradually increased. About the ninth day a mild solid diet may be ordered.

Very mild cases have recovered completely in ten days. Others will require the use of peptonised food, tonics, and massage. 


\section{APPENDIX D \\ COMPLAIN'T OF 'TARDY NO'TIFICA'TION OF YELIOW FEVER}

That other colonies in the West Indies did not think the medical organisation of Barbados was equal to grapple with the epidemic of yellow fever of 1908-9, we have had evidence already.

These criticisms all point in the one direction to the disadvantage of Barbados of not possessing a medical head in the colony.

The following is additional testimony in this direction, and was a minute sent by Sir Frederic Hodgson to the SurgeonGeneral of British Guiana upon the report of Dr Hutson on the sanitary organisation of the parish of St Lucy, Barbados :-

It is clear that some of the parochial medical officers for Barbados are not co-operating with the Board of Health, and in fact are neglecting, either through ignorance of the aspects of yellow fever cases or otherwise, to effect prompt isolation and to take other steps required by the Board. It was so in the case of the smallpox epidemic of 1903 .

2. I am afraid that yellow fever will become more rampant in Barbados than it is, and in the Demerara Daily Argosy of the 4th inst. there was an account of Dr Hutson's action and a statement to the effect that 40 cases had occurred in the island.

3. The Health Officer will have to be very watchful. Let the Surgeon-General see this minute.

$2 / 2 / 1907$.

Frederic H. Hodgson. 


\section{APPENDIX E}

\section{ANTIPLAGUE MEASURES IN JAMAICA}

The following manifesto has been issued, July 1909, to the citizens of Kingston, Jamaica :-

By recent telegrams from Trinidad we are informed that there have been cases of bubonic plague in that island, most of which have terminated fatally. That this awful disease should have reached Trinidad was dreaded by all in authority, and especially those cognisant of the intimate relationship that exists between Venezuela and Trinidad.

Trinidad is brought into closer proximity to Jamaica by the fast steamers of the Royal Mail Company and other lines to Central America, and this makes it absolutely necessary for the people of Jamaica to take every precaution in their power to prevent the introduction of such an awful scourge to our island.

This fell disease is most insidious, taking in some instances weeks before it gets fully developed, and cases are on record where two months and more have elapsed between the introduction of the infection and the outbreak of the epidemic. This disease is also more fatal than any known disease, including smallpox, yellow fever, and cholera, and also more difficult to eradicate. Therefore it is absolutely necessary that every citizen should do his best to protect not only his own life and the lives of those near and dear to him, but also the welfare of the entire community.

Plague is introduced and propagated by many of the lower animals, rats being the worst offenders in this respect. Mice, squirrels, and monkeys also carry the infection but in a lesser 
degree. In fact, there is almost invariably an outbreak of plague amongst rats previous to an epidemic of this disease in man.

Plague is transmitted from the rats to man by the agency of fleas. It is therefore quite evident that personal cleanliness, and good and sanitary environment, are important adjuncts to the prevention of an outbreak of this disease. Writers on this subject in India have shown that persons who habitually walk barefooted are more liable to contract the plague than those who wear boots and shoes.

Dead rats are invariably found before an epidemic of plague breaks out. The importance of notifying any unusual mortality or sickness amongst these animals is not only advisable, but is a duty cast on every citizen of the community. Citizens of Kingston keep well in mind the following rules, and carry them out:-

1. Exterminate all rats and mice.

2. Keep your yards and houses clean and sanitary.

3. The keeping of eats and dogs is recommended.

4. Get and keep in touch with the sanitary inspector for the district in which you live.

This appcal is issued at the instance of the special committee appointed by His Excellency the Governor, for the destruction of rats.

RoB'T. JOHNSTONE, Acting Colonial Secretar\%.

THE RA'T ORDINANCE, GRENADA, 1909

Regulations for the Destruction of Rats, etc., on Vessels.

1. Any medical officer on becoming aware, or upon suspecting that any vessel lying within any waters of the colony is infested with rats or other vermin, is hereby empowered to strictly enforce the adoption of such measures as may in his discretion be deemed most efficacious for the purpose of exterminating the said rats or vermin, and of preventing such rats or vermin passing from such 
vessel to the shore, or from the shore to such vessel. Such measures may include the following:-

(a) Require the owner, master, or person in charge of the vessel when at any mooring, or when loading or unloading cargo at any port within the colony, to use rat-guards of a pattern approved by the said officer on every rope, cable, or such-like communication passing between such vessel and the shore, or between the vessel and any lighter or barge or other vessel, or between the vessel and its buoys or anchors, or the moorings.

(b) Require the owner, master, or person in charge to generally abate all insanitary conditions where they exist, and to effectually remove or burn all rubbish and deposits on the vessel likely to harbour rats or vermin.

(c) Whenever it shall appear to the medical officer that the rats or vermin can only be exterminated by cleansing and disinfection in a specified manner, the medical officer may, by notice in writing, either require the owner, master, or person in charge of the vessel to clcanse and disinfect or fumigate the same accordingly, or may inform such owner, master, or person that it is the intention of the medical officer to conduct such cleansing and disinfection or fumigation at a time to be specified in the notice.

2. Where the owner, master, or person in charge of such vessel fails to comply with any requirements made under these regulations, or is, from poverty or otherwise, unable to effectually carry out such requirements, the medical officer may cause the requisite measures to be taken forthwith, and the expenses thereby incurred may, at the discrction of the General Board of Health, be either defrayed from general revenue, or be recovered wholly or in part from such owner, master, or person.

3. It shall be the luty of all port, revenue, and police officers 
to assist the medical officers in enforcing the provision of, and preventing any infringement of, these regulations.

4. Any person acting in violation of these regulations, either by way of refusing to obey any requisition or instruction made or given hereunder, or by obstructing in any way the due execution of these regulations, renders himself liable to a fine not exeeeding $£ 5$.

Made by the Governor in Couneil, this 21st day of June 1909.

\author{
T. T. DYER, \\ Clerk of the Council.
}

In British Guiana and Trinidad, measures have been taken against rats by the regular collection and destruction of town refuse and by the use of rat poisons.

In British Guiana, I pointed out that the removal of the superabundant bush which had grown up in the towns would materially assist this work, and I have reason to believe the suggestion has been acted upon.

In Trinidad, special regulations dealing with plague were made in August 1907. A eampaign against rats was also instituted, as is seen from the following extract from a report of the SurgeonGeneral :-

Since the 30th May 1906, there has been eighteen cases of plague and fourteen deaths in Port of Spain; the last two cases occurred on the 4th and 26th July respectively-the last death on the 28th July; and the last convalescent case was discharged from the Isolation Hospital cured on the 13th inst.

There have been caught only five infected rats (about 0.2 per cent.), all within the infected area of the town; the last infected rat caught was on the 17 th July.

All the inspecting medical officers report vastly improved sanitary conditions of the premises within the infected area, which continues to be kept under very close medical and sanitary supervision, and the eampaign against rats is actively maintained by poisons and traps in eharge of special officers and gangs and by rewards of 5 cents per head for each rat, alive or dead, delivered under certain conditions. 
As regards shipping, vigilance continues to be exercised over arrivals and departures from here-with special reference to the prevention of access to vessels by rats, the use of rat-guards of efficient pattern being enforced, and vessels anchored less than two miles from shore are prohibited from working cargo except during daytime, etc. It is not proposed at present to relax any of the precautionary measures in operation for maintenance of the good sanitary condition of the town or for the prevention of the spread of infection (should any still exist here) to other countries.

Amongst the measures which have operated to reduce the rat nuisance in Trinidad are undoubtedly the increased sanitary inspection of the town, the cementing of backyards, and the removal of rubbish.

In the new draft Health Ordinance 1909, clauses of an up-todate character are to be inserted dealing with the prevention of plague. 


\section{APPENDIX F}

ERUP'IIVE FEVER; VARICELLA; VARIOLOID VARICELLA; ABOR'TIVE, IRREGUI.AR, OR A'TYPICAL SMALLPOX; GIAN'T CHICKENPOX; CUBAN ITCH; VARIOLA-AMBULANS; IMPE'IIGO CON'IAGIOSA

Under these headings are grouped certain diseases of the smallpox type which require investigation. They are a souree of great difficulty, for by some they are considered to be genuine eases of smallpox and by others not. The result is that difficulty arises upon the necessity or advisability of notification for intercolonial quarantine purposes. In my opinion, these diseases are of much scientific interest, and would well repay investigation; for whatever their nature, they appear widely distributed, and have been described in the United States and in Canada; they have also been observed in Venezuela, Trinidad, and Grenada, and in other places.

Drs Dickson and Lassalle have furnished an interesting report upon the epidemie in Trinidad of 1902 to 1903 . These officers investigated 4029 cases, and furnish tables showing the ineidence of the disease amongst the vaccinated and unvaccinated. In their opinion, recent vaccination and revaccination protects from the disease, although their tables show the occurrence of the disease almost equally amongst the vaccinated and unvaccinated. The Surgeon-General of Trinidad states that the discase was probably introdueed into that island from Venezuela, as the same disease was reported in the coastal villages of Venezuela. As there is a large daily passenger and freight traffie between the Port of Spain and the villages on the adjacent Venezuelan coast, 
this would appear to be a reasonable view. Two medical men were sent over to Venezuela to investigate the outbreak; they visited Yrapa and Guiria, and reported that the disease which existed there was very mild, and that it went under the Spanish name of "Lechina" (chickenpox). In proof of its mildness, it was stated that many of the troopers appeared under arms covered with the eruption. Europeans did not appear to be attacked. Dr R. Seheult of Trinidad has published an excellent monograph with illustrations of the Trinidad epidemic of 1902 to 1904 , in which he comments upon similar outbreaks which have bcen described in other countries, notably in Canada and in the United States, Jamaica, and Barbados.

In Grenada I had an opportunity of discussing the disease with Dr Bennett, who has furnished a very clear report upon 71 cases of the disease. As a result of his experience, he concludes that the disease resembles smallpox more closely than any other of the recognised specific febrile diseases, but that it is certainly not the "smallpox" of our forefathers. He also observed that more vaccinated persons were attacked than unvaccinated, and several within a year after vaccination. Vaccination, however, had a marked controlling influence over the course of the disease; the rash, for example, was cut short.

The Colonial Secretary at the time of the epidemic drew the attention of the medical officers to the occurrence of a similar disease in Ontario, Canada. 


\section{APPENDIX G}

\section{HEALTH PROGRESS IN 'THE FRENCH WES'I INDIES, MARTINIQUE, AND GUADELOUPE}

An outbreak of yellow fover having occurred in Martinique, 19081909, a committee of French medical experts ${ }^{1}$ was sent out to investigate the epidemic. Thanks to their reports, which have quite recently been published, we are in a position to compare this yellow fever outbreak with those which took place almost simultaneously in the British West Indies, and which I have discussed in the preceding chapters. We are, moreover, enabled to see how far the general anti-yellow fever and antimosquito regulations, as put into operation in the French Colonies, correspond with those practised in British Colonies. The epidemic was confined to Martinique, and for this reason the Commission gives us no information regarding the sanitary conditions prevailing in Guadeloupe, nor the distribution of the Stegomyia in that island. This is a pity, for every effort should now be made to unify the regulations against stagnant water, in order to bring about the elimination of yellow fever and malaria from the West Indies.

Yellow Fever in Martinique and Guadeloupe in the Past.

Like the other islands of the Antilles, these colonies were no doubt endemic centres of yellow fever. We know that a large epidemic occurred in 1735 at St Pierre in Guadeloupe, and

${ }^{1}$ Drs Simond, Aubert, Grimaud and Noc, Annales de L'Institut Pasteur, Nov. and Dec. 1909; and Aunales d'Hygiene et de Médecine coloniale, 1909. 

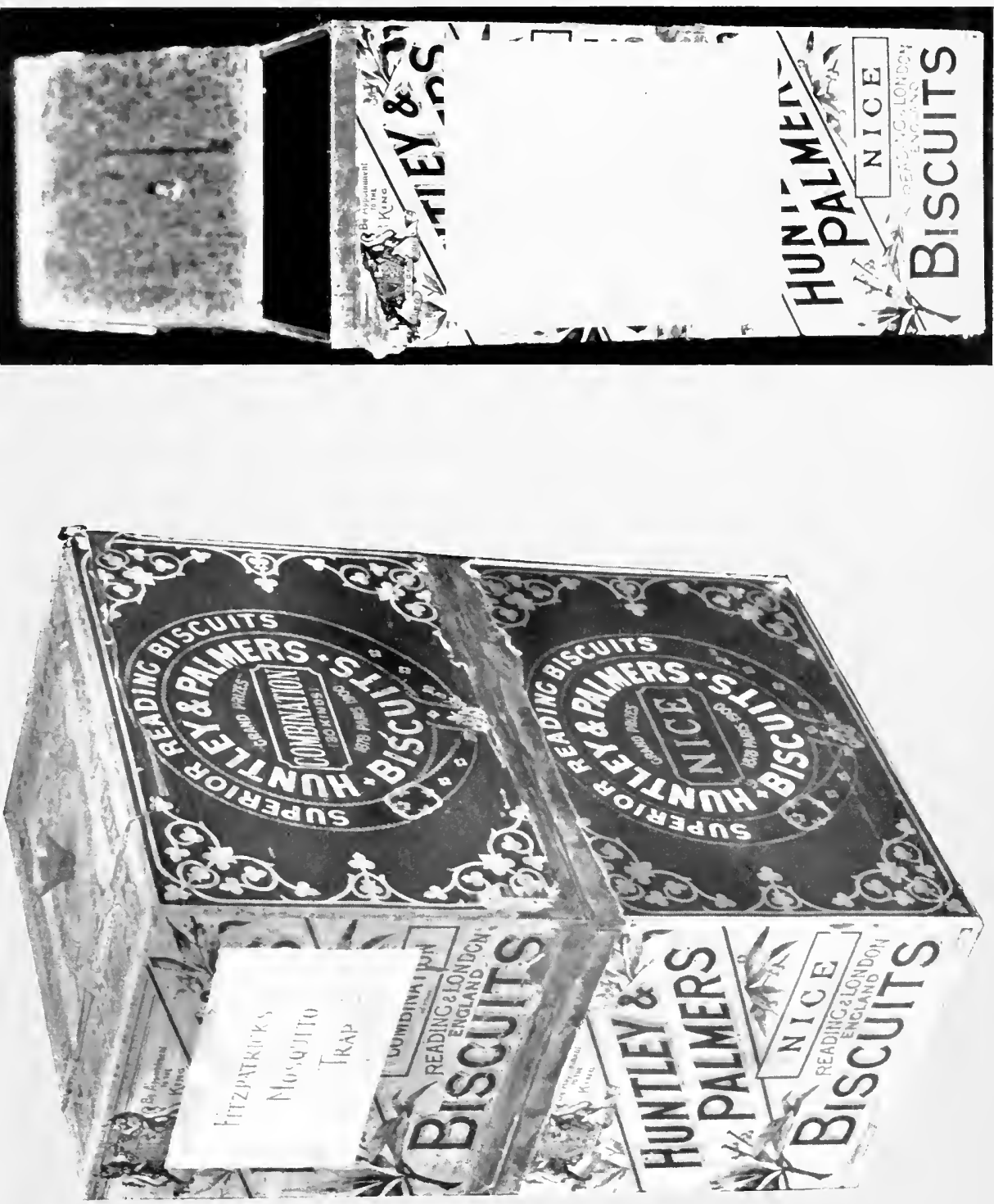

Père Labat described the epidemic of 1649 which passed over Martinique, and was then known as the Maladie de Siam, the disease having been supposed to have been introduced from Siam. In the years 1816 and 1821, epidemics are also described in Guadeloupe. The report of the recent French Commission also makes it clear that yellow fever has been endemic until recent times ; large outbreaks occurred at certain periods, as, for example, in the years $1850-1853,1855-1857,1887-1888$, and in 1895 , but in the intervals there was reason to believe that suspicious cases, in all probability mild forms of yellow fever, occurred continuously up to the recent 1908-1909 outbreak.

It would appear evident from this, that Martinique was an endemic focus until quite recently, and that the disease manifested itself in the Creole population in a particularly mild form, the so-called "inflammatory fever," an attack sufficient to confer partial immunity upon those affected, but able to fully infect the Stegomyia.

It is worthy of note, in view of what has already been said concerning the periodicity of yellow fever outbreaks, that the previous large outbreak of the disease occurred in 1895 .

\section{History of the Recent 1908-1909 Outbreak.}

The Commissioners state that whilst the local medical men were inclined to believe in the local origin of the yellow fever, they thought that the disease might have been in some mysterious way revivified or augmented. This is only a survival in the minds of the local medical men of the old miasm theory, and is one which I have several times encountered in the West Indies.

The Commissioners investigated the probabilities of the introduction of the disease from without, and in their report refer to the parallel outbreaks of yellow fever in Trinidad, Barbados, and Surinam.

Upon the whole evidence, they conclude in favour of the local origin of the disease, a circumstance which is exceedingly interesting to the student of yellow fever.

The epidemic broke out in Fort-de-France, and from thence spread to all parts of the island. 
There appears to be no doubt that there were very numerous mild cases of yellow fever, diagnosed as "inflammatory fever," amongst the native Creole inhabitants, which were entirely overlooked, but which, nevertheless, infected the Stegomyias, and these in their turn infected the non-immunes, especially those more recently arrived.

During the epidemic there was an excellent opportunity of observing the effect of antistegomyia measures at Balata Camp. Previous to sending the soldiers to this station, there had been a vigorous antilarval crusade organised by Colonel Roulet, and as a result there were very few cases of fever amongst the men, and the few cases which did occur could be traced to infection contracted outside the camp, either at Fort de France or in the houses of natives scattered along the roads leading up to the camp. On the other hand, outside the camp, in the houses of the natives, where there existed abundant breeding places of the larvæ, yellow fever continued and spread.

The total number of certain cases is given as 206 from February 1908 to February 1909, but in all probability there were far more cases which assumed a very mild type, especially amongst the children. These may have amounted to 922 cases. The observers lay quite rightly very great stress upon the mild cases of fever amongst the young Creole population, cases which would be sure to escape detection, but which, nevertheless, would cause Stegomyia infection. They also point out how in certain districts a good water-supply had brought about a very material reduction in the total number of breeding places of the Stegomyia, and in consequence a comparative immunity from the disease.

The Commissioners point out that the epidemic occurred at first in a mild form amongst the Creoles, followed later by deaths amongst the Europeans. They also discuss the question whether mild cases of yellow fever existed previously amongst the native Creoles, and they conclude that a mild form has probably always existed amongst them, mild enough to give rise to a partial though not complete immunity; and in support of this, they mention that it is a well-known observation that Creoles who are long absent from the island lose their immunity. They also discuss the question of recurrence, and regard the Martinique epidemic as supporting the opinion that had already heen arrived 
at in Brazil by Simoud and Marchoux-namely, that recurrences could take place, especially amongst those who, when they were young, had had mild attacks which were probably diagnosed as some other fever. In these cases, the secondary attacks were mild, and were precisely the cases which in the Creoles were diagnosed as inflammatory fever. They also state, however, that they noted some recurrences amongst Europeans. They lay stress upon the question of recurrences, and in support of it, mention the well-known facts about recurrences in connection with typhoid and other infectious diseases: that is to say, that there are various degrees of immunity. This contention is all in support of the presence in endemic centres of disease of the so-called chronic or ambulatory cases of yellow fever to which we have previously drawn attention, and which are in all endemic centres the source of the infection for the new arrivals.

Just as in the case of Barbados, where vigorous antilarval measures and fumigation led to the suppression of the fever at an early date in Bridgetown, whilst it persisted in the country districts, so also in Martinique. In Fort-de-France, owing to more active and controlled antimosquito measures, the fever was stopped in December 1908. On the other hand, it persisted till February 1909 in the outside districts, where antimosquito measures were less perfect.

\section{Prophylactic Measures.}

It does not appear from the report that previous to the mission there existed in the island any antilarval ordinances similar to those in many of the British West Indian Islands. The Commission therefore started at once to educate the public - to co-operate with them and the Government. A brigade was organised and house-to-house inspections made; all water receptacles were carefully examined, as also the gutters of the houses. By an order of the Governor, made in December 1908, all houses were regularly inspected and water containing larvæ thrown away, and the occupants were instructed to change drinkingwater at least once a week, and to thoroughly clean the receptacles each time. 
They were ordered to clean out all gutters and to bury all odd receptacles. Oil was put into all stagnant water, and frequent visits were paid to the houses to see how far the order had been obeyed. The measures taken to destroy the adult Stegomyia in houses where cases of yellow fever had occurred were the usual ones. The result of the antilarval measures and fumigation was to produce a very noticeable reduction in the number of mosquitos. The report does not say whether, as the result of the mission, permanent antilarval measures were introduced. As the future security of the island will entirely depend upon this action, it is to be hoped that the French authorities will make it an offence to keep stagnant water, as in the case of other islands of the Antilles.

\section{AN'IIMOSQUI'TO LAWS.}

As the result of a report from the Minister of the Colonies, pointing out the inadequacy of the existing local laws to meet the emergency in the island, and that up-to-date regulations were necessary, the following decree was signed by the President of the French Republic:-

\section{Le Président de la République française.}

Vu le sénatus-consulte du 3 mai 1854;

Vu la loi du 3 mars 1822 sur la police sanitaire;

Vu la loi du 30 novembre 1892 sur l'exercice de la médecine;

Vu le décret du 17 août 1897, portant règlement d'administration publique pour l'application aux colonies de la loi du 30 novembre 1892 sur l'exercice de la médecine;

Sur le rapport du ministre des colonies.

\section{Décrète :}

Art. ${ }^{\text {er }}$ - - La colonie de la Martinique est soumise temporairement au régime sanitaire tel qu'il est déterminé par l'article $1^{\mathrm{er}}$ de la loi du 3 mars 1822 sur la police sanitaire.

Art. 2.-Le gouverneur détermine par arrêté :-

$1^{\circ}$. Les précautions à prendre pour prévenir ou faire cesser les maladies transmissibles, et notamment la fièvre jaune, et spécialement les mesures d'isolement obligatoire des malades dans les 
locaux affectés à cet usage, dans les cas où l'autorité sanitaire le jugera nécessaire; les mesures de désinfection ou même de destruction des maisons dont la désinfection aura été reconnue impossible, et dont la conservation constituerait un danger permanent; de désinfection ou de destruction des objets à l'usage des malades ou qui ont été souillés par eux, et généralement des objets quelconques peuvent servir de véhicule à la contagion ;

$2^{\circ}$. Les prescriptions destinées à assurer la salubrité des maisons et de leurs dépendances, des voies privées closes ou non ¿ leurs extrémités, des logements loués en garni et des autres agglomérations, quelle qu'en soit la nature, notamment les prescriptions relatives à l'alimentation en eau potable ou à l'evacuation des matières usées, à la destruction des rats, des moustiques et des autres insectes dangereux pour la salubrité publique.

Art. 3.-Le gouverneur règle, par arrêté, les attributions, la composition, la compétence des autorités et le ressort des administrations chargées de l'exécution de ces mesures, et leur délègue, pour un temps determiné le pouvoir de les exécuter.

L'arrêté doit spécifier les conditions et moyens financiers d'exécution de ces mesures. Ces arrêtés sont immédiatement exécutoires.

Art. 4.-Lorsque l'insalubrité d'un immeuble est le résultat de causes extérieures et permanentes ou lorsque les causes d'insalubrité ne peuvent être détruites que par des travaux d'ensemble, Ia commune ou la colonie, suivant les cas, peut acquérir, après expropriation, suivant la législation locale, la totalité des propriétés comprises dans le périmètre des travaux; les portions de ces propriétés qui, après assainissement opéré, resteraient en dehors des alignements arrêtés par les nouvelles constructions, peuvent être vendues aux enchères publiques, sans aucun droit de préemption pour les anciens propriétaires ou leurs ayants droit.

Art. 5.-Sera puni d'un emprisonnement de trois à quinze jours et d'une amende de 5 à 50 fr. quiconque aurait contrevenu, en matière sanitaire, aux règlements généraux et locaux, aux ordres des antorités compétentes.

Art. 6.-La loi du 3 mars 1822 et le présent décret seront publiés et affichés dans toutes les communes du territoire de la Martinique. 
Art. 7.-Le ministre des colonies et le gouverneur de la Martinique sont délégués conformément à l'article $1^{\text {er }}$ de la loi du 3 mars 1822, pour assurer l'exécution du présent décret, qui sera publié au Journal officiel de la République française, au Bulletin des lois et au Journal officiel de la colonie.

Fait à Paris, le 11 novembre 1908.

A. Fallièress.

Par le Président de la République:

Le ministre des colonies,

Milliès LaCroix. 


\section{APPENDIX H}

\section{HEAL'TH PROGRESS IN THE REPUBLIC OF CUBA AND IN POR'TO RICO}

It is in these islands that the most brilliant and instructive results of sanitary reform are met with. The sanitary reformation of Havana, and indeed of the whole of Cuba, has now become one of the historic examples of the practical value of sanitation, whilst the reports upon the prevention of tropical anæmia in Porto Rico are a model to all the other Antilles.

\section{Republic of Cuba.}

In April of last year, 1909, there was issued the first number of the official journal of the Department of Public Health and Charities. In this most excellent scientific publication, reports are regularly issued upon all matters of interest to the Public Health of the Colony, including accounts of all the chief diseases and the methods employed to get rid of them. These embrace antimosquito measures, vaccination, isolation, hospitals and dispensaries, nursing staff; training of sanitary inspectors and nurses; education of the public; teaching of hygiene in the schools; organisation against tuberculosis. Researches are also carried out in tropical diseases.

The advance in sanitary reform has been strikingly rapid, and dates from 1898. Up to this date, as the journal states, the Government had, during a period of 400 years, failed not only to govern and to civilise the native inhabitants, but sanitary and charitable organisations were left to take care of themselves.

It was not to be wondered at that, in the year 1898, smallpox, 2929 
malaria, yellow fever, scarlet fever, glanders, diphtheria, and tuberculosis were exceedingly prevalent throughout the island. Havana was a pest-house, one of the notorious endemic centres of yellow fever. Indeed yellow fever has been known in Cuba from the earliest times. In 1620 , the disease went under the name of the Pest of Havana, and it remained endemic up till 1900; yet, when the first number of the official journal appeared in May 1909, Dr John Guiteras wrote: "Prosperous indeed are the auspices under which the first number of the Public Health and Charities Bulletin appears, announcing that the territory of the Republic is entirely free from smallpox, yellow fever, and the bubonic plague!"

What were the forces which brought about this sanitary revolution in a population of $1,570,000$ souls?

In 1898, the American Government assumed the administration and organised the Public Health administration, with the assistance of Gorgas, General Wood, Kean, Finlay, Guiteras.

One of the first acts of the new administration was to appoint a commission to find out what was yellow fever.

We all now know that the young medical officers who were appointed-namely, Reed, Carrol, Agramonte, and Lazear-proved to the world how yellow fever was carried. It was by acting upon these experiments that yellow fever had ceased to be endemic in the island for the first time in history, and that it can be said that to-day deaths occur in Cuba in the same proportion as in cold or temperate countries, where most scrupulous hygienic measures are in force!

All this has been largely the result of unconditional war upon the mosquito. Does an island in the Antilles still exist which requires a more convincing demonstration?

Colonel Kean remained adviser to the Sanitary Department of Cuba until the commencement of 1909. Then the Department of Health and Charities of the Republic of Cuba was founded. It is a Department of the Government, and there are connected with it eighty-two local health officers for the various provinces, and in addition, medical officers of health for Havana itself, and some twenty-five physicians employed in various capacities.

There is also a National Board of Health and Charities, composed of a Board of thirteen nrembers, with an honorary President. 
It is an advisory body, which recommends or reports to the Secretary of the Department of Health and Charities. The Secretary to the Department is Dr Matias Duque. Dr Duque, in stating his reasons for the publication of the official bulletin, says the publication has a twofold object: "First, to carry out the provisions of the law; and, secondly, to place ourselves in contact with the rest of the world, in order to let it know what we are doing for health and charity. . . . We are obliged to maintain a good sanitary condition in our own interest, for our national pride, as altruism toward the men of other lands, who should come to our shores without any apprehensions, and in order that we may be received in theirs without fear that we may carly transmissible diseases. This is the only reason why we consider ourselves bound to preserve the public health at any cost."

Could a young republic start on its career with finer aspirations? Let us hope that the other islands of the Antilles will follow the splendid example of the "Pearl" of the group.

\section{Porto Rico.}

Once an endemic focus of fevers has now been brought into linc, and one of the most brilliant reforms has been the appointment of a permanent Commission for the suppression of uncinariasis or tropical anæmia in the year 1905. Previously to that date, in 1904, however, investigations had been commenced.

This Commission has presented two most excellent reports dealing with the causes of the disease, and the methods of prevention and treatment.

The reader is recommended to consult the reports published in 1905 and 1907 for full particulars of the plan of campaign. It is sufficient to know in this place that the results are excellent, and that the methods of prevention should be closely studied by those colonies desirous of getting rid of ankylostomiasis. 


\section{APPENDIX I}

\section{HEALI'H PROGRESS IN JAMAICA}

As in the case of the other islands, Jamaica was at one time an endemic focus of yellow fever (vide Chapter II.).

Vast improvements have, however, been made in sanitary administration, and endemic yellow fever has been stopped.

Considerable attention has also been paid to antiplague measures, as we have already seen in the Appendix. A great deal yet remains to be accomplished in getting rid of insectcarried diseases, and recently a Report ${ }^{1}$ has been issued by a small commission sent out by the Liverpool School of Tropical Medicine, in which attention is drawn to the necessity of energetic, systematic, and well-directed antimosquito work in order to rid the island of malaria. The Report consists of two portions, one by Mr Newstead, dealing with the medical and economic entomology, in which a careful description is given of the ticks of the island and the diseases which they produce in cattle; also, an account of the natural enemies of the ticks, and the remedies which should be adopted against these pests. In the second portion of the Report, Dr Prout deals with the distribution of the anophelines in Jamaica, and with the prevalence of malaria.

According to the Report, practically no antimalarial measures have been undertaken, and there certainly do not appear to be any drainage bye-laws, or anti-stagnant water ordinances similar to those which exist in the sister colonies, This reveals a state of affairs which calls for early rectification, and it appcars reasonable to suppose that this will be done under the present Government, for those in charge of the Administration are fully alive to the importance of making Jamaica attractivo to the tourist,

${ }^{1}$ Annals of Tropical Medicine and Parasitology, Liverpool, 1904. 302 
as well as to the trader, and the Colonial Secretary has already had great experience in antimosquito work, both in British Honduras and in St Lucia. At the present time, judging from the local press, there appears to be a general desire to carry out antilarval operations on a proper basis, so as to bring Jamaica up to the front rank, and, as I have said, the auspices are exccedingly good. 


\section{APPENDIX J}

\section{HEALIT PROGRESS IN 'THE BAHAMAS AND NOR'THERN ISLANIS}

\section{The Bahamas.}

These islands were also at one time the home of endemic fevers. Thanks to sanitary reforms, and to wise legislative measures, as, for example, the antimosquito rules (1907) of Nassau (Chapter VI.), great improvement has taken place.

\section{Northern Islands.}

In these islands, as we have seen in Chapter II., yellow fever was also very eommon. Vigorous antimosquito work has, however, been undertaken, as we have seen, in Antigua, eommencing in 1904. 


\section{APPENDIX K}

\section{HEALTH PROGRESS IN BRI'TISH HONDURAS}

Although this colony is on the mainland, yet it is usually grouped with British Guiana and the West India Islands. In fact these colonies constitute a natural group, and for sanitary, administrative, and medical purposes it is desirable to study them as a whole. In 1905, I visited the colony to report upon an outbreak of yellow fever which had occurred, and to suggest measures to prevent its recurrence. ${ }^{1}$

The numerical strength of the colony was then small, so that the number of newcomers or non-immunes must have been very small. The permanent population were no doubt for the most part immunes, having probably at some time of their life suffered from yellow fever in a mild or severe form.

The origin of the 1905 outbreak might, therefore, be attributable to either Stegomyia infected from mild, acute, or chronic indigenous unrecognised cases of yellow fever, or from Stegomyia freshly infected from imported cases of yellow fever. I inclined to the latter view, although I now admit the possibility of the former view.

My steps in order to eradicate the Stegomyia calopus were to make a survey of its breeding places. I then urged the necessity of introducing water-screening ordinances, and the better supervision of all yards in order to remove all odd receptacles which might contain stagnant water. I further advised strict quarantine supervision, and the adoption of the United States system of sending a medical officer to any suspected port to

${ }^{1}$ Report to the Government of British Honduras upon the outbreak of Yellow Fever in that colony in 1905. 
ascertain facts, and also to travel on the ships in order to keep passengers and crews under observation.

My recommendations were largely acted upon, and the results as judged by the past five years have been satisfactory, for in so far as I am aware no case of yellow fever has occurred in Belize, and the medical representative of the United States Marine Hospital Service stationed in Belize has, from time to time, reported marked diminution in the number of Stegomyia, and the faithful carrying out of the screening regulations, removal of odd receptacles, and general sanitary inspection. Much also has been done to render the lots in Belize less waterlogged. A most interesting circumstance occurred in 1907, when dengue fever broke out in the colony; the United States Marine Hospital Service thought that it might possibly be a yellow fever outbreak, and so sent their representative to investigate matters previous to closing the port. The representative reported after examination that as no Stegomyias were to be found in Belize, the disease could not be yellow fever, and in consequence quarantine was not imposed upon the port. Drainage operations and bush-clearing has been commenced in and around Belize, and the Medical Officer's Report shows a distinct diminution of malaria.

\section{The Mosquito Destruction Ordinance, 1906.}

Be it enacted by the Governor of British Honduras, with the advice and consent of the Legislative Council thereof :-

5. The owner or person in control of any cistern or vat, tank, barrel, bucket, or other vessel used for the storage of water shall, within such time as may be specified by notice, protect the same from mosquitos in the following manner, that is to say-

Cisterns, tanks, vats, and barrels shall be provided with covers of wood or metal, and all openings other than the delivery exit shall be screened with netting;

Buckets and similar or other containers shall be protected in the same way as cisterns, or in some other manner approved by the Board. 
6. Owners and occupiers of premises on which there is any water in wells, ponds, pools, or basins, or in depressions or excavations made for any purpose, or which by any means have occurred, and in which mosquitos ean breed, shall, within such time as may be specified by notice, protect the same from mosquitos in the following manner: that is to say-

Stock them with mosquito-destroying fish;

Or cover them with protective netting;

Or drain them off at least once every week;

Or cover them with oil at least once a week;

Or fill them up;

Or (in the case of wells) provide them with a pump and mosquito-proof cover to the satisfaction of the Board.

7. All empty and open tins shall be kept in such a position as to prevent mosquitos breeding in them; and all old receptacles, such as jars, broken crockery, condensedmilk tins, and other rubbish which form receptacles for water shall be removed or buried. All doreys, pitpans, and boats in use or discarded must be kept free of fresh water. Odd receptacles for water to be removed or buried, and doreys, pitpans, and boats to be kept free of water.

8. A proper officer or a health officer may, at any time between sunrise and sunset, enter upon any premises, to ascertain whether there exist breeding places for mosquitos in or on such premises, or for the performance of any act or thing which such officer may hereunder lawfully do or perform.

9. A proper officer may at any time treat stagnant water by applying oil to its surface in such a manner as to destroy mosquitos, provided that oil shall not be put into a cistern or other water-container which is properly screened from mosquitos, and provided that only refined oil be placed in receptacles containing water used for drinking. 
10. Whenever it shall appear to any Board, on the certificate of a health officer, or of any duly qualified medical practitioncr, that a case of yellow fever has occurred, or that a case of fever has occurred of which the diagnosis is doubtful, but which may possibly be onc of yellow fever, the Board shall order the fumigation of the premises in which such case shall have occurred, and also of any premises situated within one hundred yards of the said premises, and the Board may order the fumigation of such other premises as on the recommendation of the health officer it may deem advisable. Such fumigation shall be carried out by a proper officer under the supervision of a health officer.

11. Any owner or occupier failing to comply with the requirements of this Ordinance shall be liable on summary conviction to a fine not exceeding fifty dollars, and to a further penalty of five dollars for every day he continues in default after the expiration of the time specified in the notice.

12. If any person in any manner whatever assaults, resists, obstructs, intimidates, or bribes, or attempts to assault, resist, obstruct, intimidate, or bribe any officer or health officer acting in the execution of his duty under the provisions of this Ordinance, every such person shall be liable on summary conviction to a fine of not exceeding fifty dollars.

13. Whenever any owner or occupier shall have failed to comply with a notice hereunder, the Board may direct a proper officer to enter upon the premises and carry out such work as may be necessary, and as required by the notice, and shall be entitled in addition to proceeding for a conviction of any offence committed hereunder, to recover the cost of such work in accordance with the Public Health Ordinance. Provided nevertheless that where, in the opinion of the Board, any owner or occupier is from poverty or otherwise unable effectually to carry out the requirements of any notice served under 
this Ordinance, the Board may direct that any cost or expense incurred under this Ordinance may be defrayed out of funds at the disposal of the Board, or that such owner or occupier shall pay only so much of the cost and expense as in the opinion of the Board such owner or occupier is able to pay.

14. This Ordinance shall be read together with the Public Health Ordinance, and where not inconsistent with the context, the provisions of the Public Health Ordinance shall apply, so far as it is possible to apply them, to the subject-matter of this Ordinance.

15. All fines and penalties paid in respect of non-compliance with this Ordinance shall be placed to the credit of the Board instituting the prosecution.

Wilfred COLLETT.

In 1907 a most useful and practical Quarantine Ordinance was passed, dealing with yellow fever, plague, cholera, and smallpox. This Ordinance has been most efficiently carried out by the Principal Medical Officer, Dr Harrison. Every vessel is boarded, irrespective of whether it has a foul or clean bill of health.

\section{'IHE AN'TIMOSQUI'TO CAMPAIGNS IN THE LATIN REPUBLICS}

The modern sanitary awakening and the war on mosquitos has also permeated into the Latin Republics of Central and Southern America. Mexico is wonderfully well organised. The work being now done in the Canal Zone is rightly regarded as a model for the rest of the world, and Brazil has accomplished much, up till now for the most part on the Pacific side. I have reason to know, however, that, thanks to the energy of Dr Thomas, the representative of the Liverpool School of Tropical Medicine, 
and to the various expeditions which that school has sent out to the Amazon, the antimosquito measures at the various ports on that great river are becoming, and will become, greatly improved, and that no doubt endemic yellow fever will disappear. Dr Thomas's Report upon his long experience and researches in connection with disease on the Amazon will appear very shortly. ${ }^{1}$

1 " Report of the 1905-1909 Expedition to the Amazon, by H. Wolferstan Thomas," Annals of Tropical Medicine, Liverpool, vol. vi., 1910. 


\section{CONCLUSION}

I HAVE brought forward sufficient evidence in this book to conclusively prove that during the past decade an immense awakening has taken place over the whole of the yellow fever zone of the world, that is, the West Indies and on the Spanish Main, with regard to the imperative necessity of an unconditional war against insect pests. We have seen how antilarval bye-laws and ordinances have been put into force in a large number of colonies, and how in others there exist drainage and stagnant-water regulations. We have seen that as a result of these wise measures and educational effort, yellow fever has ceased to be endemic in very many places, and is in fact fast disappearing altogether from some localities. In connection with malaria, also, great improvements have taken place, and so also in the case of many other insect-carried diseases. It now remains for the few colonies in the zone which up till now have not moved vigorously, to fall into line, and declare unconditional war on the mosquito.

The splendid example of the magnificent progress which has been made in the yellow fever zone should 
stimulate all tropical countries to follow suit. Africa has commenced in earnest; India, with its overwhelming advantages and prestige, should now make every effort to repeat what has been done with such marked success in Cuba, Panama, Mexico, and Brazil. 


\section{GENERAL BIBLIOGRAPHY}

\section{HISTORICAL AND DESCRIPTIVE}

Travaux scientifiques de Louis Danil Beauperthuy, Docteur en médecine des Facultés de Paris et de Caracas, Naturaliste Français et Micrographe. Bordeaux, 1891.

The Black Death. Gasquet, 1908.

New York Medical Journal, 4th August 1906. A. Agramonte.

Moustique et Fièvre Jaune. Chantemesse et Borel, 1905.

Recherches pratiques sur la Fièvre Jaune. A. J. Dariste, 1825.

Die Ursache d. gelben Fiebers $u$. d. Resultate d. prophylakt. Behandlg. desselben. W. Havelburg. Leipzig, 1905.

History of Yellow Fever. George Augustin. New Orleans, 1909.

Tropical Medicine, Hygiene, and Parasitology. G. E. Brooke. London, 1908.

A Study of Yellow Fever. Parker, Beyer, and Pothier. Washington, 1903.

"The Stegomyia and Fomites in Yellow Fever." S. Chaille. Reprinted from the Journ. Amer. Med. Ass., 23rd May 1903.

La Fièvre Jaune: étude basée sur des observations personnelles. J. T. Dupuy. Paris, 1904.

Naval Chronology. Isaac Schomberg. London, 1802.

Recherches sur les différentes maladies qu'on appelle Fièvre Jaune. J. A. Rochoux, 1828.

"The Essential Rôle on the Pneumogastric Nerves in Yellow Fever as shown by Experiments. With Remarks." Adrian Hava. Reprinted from the New Orleans Medical and Suryical Journal, April 1898.

"A Preliminary Report on Cells found in Yellow Fever Blood. With Reference to the Etiologic and Diagnostic Significance." O. L. Pothier, Joseph Hume, F. H. Watson, and M. Couret. Reprinted from the Journ. Amer. Med. Ass., 23rd September 1905.

IItundbook of Geographical and Historical Pathology. Hirsch. New Sydenham Society, London, 1885.

Naval and Military Memoirs of Great Britain. Robert Beatson, 1814.

"Remarks on the History, Cause, and Mode of Transmission of Yellow Fever, and the Occurrence of Similar Types of Fatal Fevers in 313 
Places where Yellow Fever is not known to have existed." Reprinted from Journ. of the Association of Military Surgeons of the United States, 1903.

"Bionomics, Experimental Investigations with Bacillus Sanarelli and Experimental Investigations with Malaria, in connection with the Mosquitos of New Orleans." G. Beyer, O. L. Pothier, M. Couret, and I. I. Lemann. Report of the Mosquito Commission to the Orleans Parish Medical Society.

Liverpool School of Tropical Medicine, Memoir XIX., Yellonv fiever Prophylaxis in New Orleans, 1905. R. Boyce.

New Orleans Medical and Surgical Journal, May 1904; September and December 1905.

Traité pratique de la Fì̀vve Jaune observée à la Nouvelle-Orleans. P. F. Thomas, 1848.

Report of the Yellow Fever Epidemic of 1903 at Laredo, Texas. C. M. Guiteras.

"A Brief Review of the Atiology of Yellow Fever. An Address before the American Society of Tropical Medicine." J. Carroll. Reprinted from New York Med. Journ. and Plila. Med. Journ., 6th to 13th February 1904.

"The Prevalence and Diagnosis of Yellow Fever in the Coloured Race." C. M. Brady. Read before the Orleans Parish Medical Society, 11 th November 1905.

"Études sur la Fièvre Jaune." E. Marchoux et P. L. Simond. Extrait des Annals de l'Inst. Pasteur, tome xxv., 1906.

Notes on Yellow Fever. C. J. Manning, 1909.

Notes on Lectures on Elementary Hygiene. J. R. Dickson, 2nd ed.

"Yellow Fever," a popular lecture. Reprinted from American Medicine, vol. ix., No. 22, pp. 907-15, 3rd June 1905.

La Fièvre Jaune sous les 'Tropiques. J.G. de Baroncelli. New Orleans, 1905.

Fièvre Jaune et traite des noirs. M. F. M. Audouard, 1849.

T'wentieth Century Practice. Edited by T. Stedman. Vol. xx., "Tuberculosis, Yellow Fever, etc." London, 1900.

Erwiederung auf Below, "Schwarzwasserfieber ist Gelbfieber." F. Plehn. Deut. Med. Woch., 1895, p. 485.

Das Gelbfieber. A. Soldré und M. Couto. Wien, 1901.

Mémoires sur la Fièvre Jaune, considerée dans sa nature et dans ses rapports avec les Gouvernements. N. V. A. Geradin, 1820.

Reports on Experiments connected with Yellow Fever. Professor Harrison and Rev. J. H. S. Moxly. Barbados, 1884.

Imprerial Department of Agriculture: Millions and Mosquitos. West Indies, 1908.

Walter Reed and Yellow Fever. H. A. Kelly. New York, 1907.

Walter Reed: A Memoir. Washington, 1904.

"Walter Reed Memorial Association." Extract from the Report of the Secretary of State jor War, 1901. 
"Experimental Yellow Fever." W. Reed, J. Carroll, and A. Agramonte. Reprinted from American Medicine, 6th July 1901.

"The Prevention of Yellow Fever." Walter Reed and James Carroll. Med. Rec., 26th October 1901.

Report of the Working Party, No. 1, of the U.S. P.H. and M.H. Service. Washington, 1903. Parker, Beyer, and Pothier.

"The Life and Work of James Carroll." Memoir read at the 5th Annual Meeting of the Society of Tropical Medicine, Baltimore, 28th March 1908, by J. M'Farland.

Public Health Reports, 1905. Past Asst.-Surg. Perry.

Public Health Reports. Treas. Dept., U.S.M.H. Service. Vol. xvi. No. 39, 27th September 1901.

Bulletins of the Yellow Fever Institute. Treas. Dept., U.S.M.H. Service. Washington.

Yellow Fever Institute Bulletin, No. 9. Washington, 1902.

"The Relation of Members of Faculty of the George Washington University to Yellow Fever Investigations." H. Donnally. "The George Washington University Publications, Medical Science Series," vol. i., No. 7, pp. 51-63. November 1906. Reprinted from the Univ. Bull., vol. v., No. 3, pp. 51-63.

"The Transmission of Yellow Fever." Read at the 54th Annual Session of the American Medical Association. Reprinted from the Journ. of the Amer. Med. Ass., 23rd May 1903.

"Personal Experience in preventing Spread of Yellow Fever." R. H. von Ezdorf. Journ. Amer. Med. Ass., Chic., 1906, vol. xlvii., pp. 11-14.

"Études sur la Fièvre Jaune." (Thèse le Paris.) F. Duflot, 1837.

"Zur ætiologie des gelben Fiebres." Dr Harold Seidelin. Berl. Kilin. Wochenschr., Mai 3, No. 18, 1909.

"Yellow Fever Prophylaxis and Means to prevent Spread in a City of Unknown Focus." H. Goldwaite. Mobile Med. and Sur. Journ., 1907, vol. x., pp. 320-322.

\section{ATIOLOGY}

"A Brief Review of the Atiology of Yellow Fever." Reprinted from the New York Med. Journ., and Phila. Med. Journ., February 1904.

"Etiologie et prophylaxie de la Fièvre Jaune." N. Najardo. Rev. med. e cirurg. de Brazil, vol. xiv., 1906.

"The Etiology of Yellow Fever. A Supplementary Note." Reprinted from American Medicine, 22nd February 1902.

"Atiology of Yellow Fever." W. Bailey. Lancet, September 1879.

"The Atiology of Yellow Fever. An Additional Note." W. Reed, T. Carroll, A. Agramonte. Reprinted from the Journ. Amer. Med. Ass., 16th February 1901.

"Ntiologie et Pathogénie de la Fièvre Jaune." Ext. des Annales de l'Inst. P'asteur', Mai 1897 
"The Etiology of Yellow Fever. A Preliminary Note." W. Reed, T. Carroll, A. Agramonte, T. Lazear. Reprinted from the Phila. Med. Journ., 27th October 1900.

"Les récentes acquisitions sur l'étiologie, le diagnostique et le Traitement de la Fièvre Jaune." Ext. de la Semaine Médicale, Avril 4, 1900.

"The Micro, Spectro, and Chemical Analysis of Black Vomit as an Aid to Health Officers in the Differential Diagnosis of Malaria and Yellow

Fevers. G. T. Kemp. American Public Health Association, 1890; and Sanatarian, 1891, vol. xxvi.

heport of Commission appointed to investigate the cause of Yellow Fever.

Wasdin and Geddings. Washington, 1879.

Report of Commission of Medical Officers detailed by authority of the

President to investigate the cause of Yellow Fever. Treas. Dept., U.S.M.H. Service, 1899.

I'raitement rationnel, curatif et préventif de la Fièvre Jaune. Chabassu, 1883.

Traité théorique et clinique de la Fièvre Jaune. L. J. B. Bérenger-Féraud. Paris, 1890.

'Traité de la Fièvre Jaune. Jean Devèze, 1820.

\section{BACTERIA}

Contributo allo studio della Febbre gialla sperimentale. A. Bruschettini, Laboratorie di Parassitologia della R. Università di Torino. Milano, 1899.

"Relazione degli ufficiali medici. Di studiare le cause della febbre gialla." Suppl. agli Annali di Medicina Navale. Anno vi., fasc. จ. Maggio., 1900.

"Zur Lehre vom gelben Fieber." G. Sanarelli. Reprinted Cent.f. Bak. u Parasit. Abt. i., Bd. xxvii., 1900.

"A Comparative Study of the Biological Characters and Pathogenesis of bacillus $X$. (Sternberg), bacillus icteroides (Sanarelli), and the Hog Cholera Bacillus (Salmon and Smith)." Journ. Exp. Med., vol. v., No. 3, 15th December 1900.

"The Germ of Yellow Fever." Lieut.-col. Charles Smart. Reprinted from the Phila. Med. Journ., 20th October 1900.

La Fiève Jaune. T. Sanarelli. [No. 8, Cuvre medico-chir.] Paris, 1898. Sur l'origine bactérienne de la Fì̀ure bilieuse des pays chauls. Domingo Friere. Inst. Bactériologique Domingo Friere. Rio de Janeiro, 1892.

\section{VACCINE}

"Bucillus icteroides and bucillus cholerw suis. A Preliminary Note." Med. Neves, 29th April 1899.

"The Bacteriology of Tellow Fever once more." lieprinted from the Medical News, 9th December 1899. 
Statistique des Vaccinations au moyen de la Culture attenuée du microbe de In Fic̀ve Jaune. D. Freire. Paris, 1891.

IIistoire de l'inoculation préservative de la Fièvre Jaune. N. B. Manzini, 1858.

Prime esperienze intono all'impiego del siero curativo e preventivo contro la feblre gialla. Roma, 1898.

\section{TREATMENT}

"Febre Amarella, Estudo-Clinico." Dr Zegerino Meirelles. Rio de Janeiro.

IIist. Méd. de la Fièvre Jaune. François et Pariset Bally. Paris, 1820.

Inangural Dissertation on Yellow Fever and on the Treatment of that Disease by Saline Medicines. H. Bone, 1846.

"Modern Treatment of Yellow Fever." A. M. Fernandaz de Ybarra. Reprinted from the Therapeutic Gazette, 15th April 1905.

"Nursing in Yellow Fever, and the Duties of Trained Nurses in Epidemics." Rudolph Matas. The Trained Nurse, vols. xxxiv.xxxv., 1905. New York.

"Sternberg Treatment." Dr Cardoso Foute. Revista de Sociedad de Med. e cirurg. de Rio de Janeiro, Abril e Maio, 1902.

"Tratamento da Febre Amarella." Dr Zegerino Meirelles. Tribuna Medica, No. 8, anno ix., 1903.

"Treatment." Dr Just Touatre. Archives de Médecine Navale, Dezembro 1900.

"The Treatment of Yellow Fever." Reprinted from Journ. Amer. Med. Ass., 19th July 1902.

"Yellow Fever: Clinical Notes." Dr Just Touatre. Translated by Charles Chessaignac. New Orleans, 1898.

Yellow Fever: A Monograph. (Charts.) J. W. Martin, 1891.

Yellow Fever: Its Nature, Diagnosis, Treatment and Prophylaxis, and Quarantine Regulations relating thereto, by officers of the U.S.M.H. Service, Washington; together with an abstract of the Report of the Medical Officers detailed as a Commission to investigate the cause of Yellow Fever. Washington, 1899.

\section{YELLOW FEVER CAMPAIGNS}

"Über Gelbfiebcrbekämpfung in unzivilisierten Ländern." Dr Otto, Hamburg. Vol. iii., p. 954, Bericht d. XIV. Internationalen hongress f. Hygiene und Demographie. Berlin, 23-29 September 1907.

The Prevention of Yellow Fever. Issued by the Colonial Office, March 1906.

"The Campaign against Yellow Fever." A. Agramonte. Vol. iii., p. 935, Bericht d. XIV. Internationalen Kongress $f$. Hygiene und Demographie. Berlin, 23-29 September 1907. 
"Ueber das Gelbfieber, sein Wesen und seine Ursachen, sowie die Schutzmassregeln gegen seine Einschleppung." M. Otto. Sonderabdruck a.d.Viertjahrsschr., u. gerichtl. Med.u. offentl. Sanitätswesen, 3 Folge xxvii., Suppl. Heft.

"The Atiology of Yellow Fever. A Preliminary Note." Walter Reed, James Carroll, A. Agramonte, and Jesse Lazear. Reprinted from the Proc. of the American Public Health Association, 28th Annual Meeting, held at Indianopolis, Ind., 22nd to 26th October 1900.

"The Etiology of Yellow Fever. An Addendum." Read at the 31st Annual Meeting of the American Public Health Association held at Washington, 26th to 30th October 1903. Reprinted from the Journ. Amer. Med. Ass., 28th November 1903.

\section{RELATIONSHIP OF TRADE ROUTES TO YELLOW FEVER}

"Train Inspection in Yellow Fever Epidemics." Surg. H. R. Carter. Ann. Rep. Marine Hosp. Service, 1898.

"Fruit Vessels, Mosquitos, and Yellow Fever," by Dr E. Graham. Journ. Amer. Med. Ass., June 1908.

"Fruit Vessels, Mosquitos, and Yellow Fever." Edmond Souchon. Reprinted from the Journ. Amer. Med. Ass., 13th June 1903.

Shipment of Merchandise from a Town Infected with Yellow Fever. Surg. H. R. Carter. Treas. Dept., U.S.M.H. Service. Washington, 1899. Second Report on Quarantine, Yellow Fever. General Board of Health. London, 1852. (A Blue-book.)

\section{YELLOW FEVER IN BRITISH GUIANA}

Some Account of the Last Yellow Fever Epidemic of British Guiana. Daniel Blair. London, 1850.

British Guiana. Report of the Commission appointed to enquire into and report upon the General and Infantile Mortality, 1906.

British Guiana Medical Annual, 1896.

"Suggestions for the Betterment of the Sanitation of New Amsterdam." An address by G. Rowland, Demerara.

\section{YELLOW FEVER IN FRENCH GUIANA}

"Quelques considérations sur les endémies de la Guyane." (Thèse-Faculté de médecine de Paris.) T. B. Cotholendy, 1857.

Contrilution à l'étude de la Fièvre du Magdalena. Carlos Esguerra, 1889.

La Fièvre Jaune à la Guyane avant 1902, et l'epidémie de 1902. A. Garnier. Paris, 1904.

"Essai sur l'hygiène de la Guyane française." (Thèse-Faculté de médecine de Paris.) P. V. Jacquier, 1837. 
Considérations sur l'hygiène et la pathologie des chercheurs d'or à la Guyane francaise. F. H. Dorvau, 1876.

"Quelques considérations sur l'intoxication paludéenne ‘̀ la Guyane française." (Thèse-Faculté de médecine, Montpellier.) T. B. Lozach, 1865 .

\section{YELLOW FEVER IN DUTCH GUIANA}

Constituiçao pestilencial de Pernambuco," cited by R. Jorge. N. Rosa. Trans. of the XV. Inter. Med. Congress, Lisbon, 1906.

\section{YELLOW FEVER IN BRAZIL}

IIistoire de la Fièvre Jaune au Brazil. E. Gouy. Paris, 1884.

Instructions sanitaires tendant à éviter la Propagation de la Fièvre Jaune.

E. Ribas. S. Paulo, Brézil, 1903.

Rapport des expériences faites à l'hôpital d'isolement de St Paul. Barreto,

Barros, and Rodrigues, 1903.

Notes on Sanitary Conditions obtaining in Para. Yellow Fever Expedition. H. E. Durham and Walter Myers. Liverpool, 1901.

Report of Yellow Fever Expedition to Para, 1900. H. E. Durham and the late W. Myers. Memoir VII. Liverpool School of Tropical Medicine.

La sanidad publica de Iquitos. H. W. Thomas, 1905.

"Report of the 1905-1909 Expedition to the Amazon." H. Wolferstan Thomas, Liverpool School of Tropical Medicine. Annales Tropical Medicine, vol. iv., No. 1. In press.

Publications of the Instituto Oswaldo Cruz. Pio de Janeiro, 1909.

"Die Bekampfung des gelben Fiebres in Rio de Janeiro. E. Bartarelli.

Wien Klin. Rundschau, 1906, vol. xx., pp. 897-99.

Memorias do Instituto Oswaldo Cruz, 1909.

\section{YELLOW FEVER IN MEXICO}

Boletim extraodinario del Consijo superior de Salubridad Mexico

Defensa contra la Fiebre Amarilla. Mexico, 1903.

"Instrucciones à los Médicos y agentes sanitarios del Servicio contra la Fiebre Amarilla." [Consejo superior de Salubridad.] Mexico, 1905. "Instrucciones à los señores Gerentes, Empleados Superieurs y Médicos de las empresas de Ferrocarril que tienen por objecto contribuir à los trabajos emprendidos por el Consejo superior de Salubridad para combatir la Fiebre Amarilla y procurar su extincion en la república." Mexico, 1905.

"Instrucciones para precaverse de la Fiebre Amarilla y de las intermitentes ú paludismo." Mexico, 1902.

"Instrucciones para dependerse de la Fiebre Amarilla e impedir la propagacion de esa enfermedad." [Consejo superior de Salubridad.] Mexico, 1905. 
New Plan of Campaign against Yellow Fever. Mexico, 1904. Nuevo Plan de Campaña contra la Fiebre Amarilla. Mexico, 1903.

"Yellow Fever, Mexico." E. Liceaga. Trans. of the XV. Intern. Metl. Congress, Lisbon, 1906.

\section{YELLOW FEVER IN BRITISH HONDURAS}

Report to the Government of British Honduras upon the Outbreak of Yellow Fever in that Colony in 1905. R. Boyce.

\section{YELLOW FEVER IN THE CANAL ZONE}

"Annual Report of the Department of Sanitation, Isthmian Canal Commission, for year. 1908."

"Bulletin No. 2. Laboratory of the Board of Health, Isthmian Canal Commission, 1906." Arthur Kendall.

"Reports of Health Officer, Isthmian Canal Commission, 1905-1907." W. C. Gorgas. Washington.

"Mosquito Work in Relation to Yellow Fever on the Isthmus of Panama." Address delivered before the Amer. Soc. of Trop. Med., 8th December 1905. W. C. Gorgas.

"Notes on the Sanitation of Yellow Fever and Malaria. From Isthmian Experience." H. R. Carter. Medical Record, vol. lxxvi., No. 2, 10th July 1909.

\section{YELLOW FEVER IN THE WEST INDIES}

"History of the Progress of Yellow Fever as it appeared in the Island of Antigua in the year 1816." A. Musgrave. Medico-chir. Transactions, London, 1818.

IIistoire médicale de l'armée française à Saint-Domingue en l'an dix; ou mémoire sur la Fièvre Jaune. C. N. P. Gilbert, 1803.

Considérations sur l'hygiène des troupes à la Guadeloupe. G. Merveilleux, 1887.

Contribution to the Medico-Military History of Jamaica. A retrospect. By Brigade-surgeon S. E. Maunsell, Jamaica, 1891

Diseases of the Army in Jamaica. John Hunter, 1788.

The Destruction of Mosquitos. Being an account of the drainage and other works carried out with this object during 1902 and 1903 at St Lucia, West Indies. Major W. M. Hodder.

"De l'endémie dyssentérique à Saint-Pierre, Martinique." Dutroulan. Extrait de la Revue coloniale, juin 1852.

De la Fièvre Jaune observée aux Antilles et sur les vaisseaux du roi, considerée principalement sous le rapport de sa transmission. P. F. Kéraudren, 1823.

"Des effets du climat des Antilles sur le système moteur." A. Moreau de Jonnés. Bulletin de la l'aculté de Médecine de P'aris, No. 8, 1816. 
Tableau du climat des Antilles, et des phénomènes de son influence sur les plantes, les animaux et l'espèce humaine. A. Moreau de Jonnés, 1817.

"Essai sur le climat et les maladies des Antilles." (Diss., Faculté de Médecine de Montpellier.) J. A. Cornette de St Cyr, 1826.

"Mémoires sur le climat des Antilles et sur les maladies qui sont particulières à la zone torride." J. Cassan. Mémoives de la Société Médicale d'Emulation, 1803.

Une page de climatologie intertropicale: les climats entre 8 et 12 degrés de latitude nord. A. Nicolas, 1887.

"Essai sur l'hygiène militaire des Antilles." A. Moreau de Jonnés, 1816.

Guide médical des Antilles, ou études sur les maladies des colonies en général, et sur celles qui sont propres à la race noive. M. G. Levacher, 1834.

Yellow Fever in the West Indies. London, 1898.

Etudes sur la Fièvre Jaune ì la Martinique. J. Cornillac, 1873.

"Rapport sur le fonctionnement du service de destruction des moustiques à la Martinique," 1908, 1909. Par Simond, Grimaud, Aubert et Noc. Annales d'Hygiène et de Médecine coloniale, No. 3, 1909.

"Contribution à l'Epidemiologie de la Fièvre Jaune de la Martinique."

Par Simond, Aubert et Noc. Annales de l'Institut Pasteur, Nov. et Dec. 1909.

\section{YELLOW FEVER IN CUBA AND HAVANA}

Anales de la Real Academia de ciencïa medicas. Carlos Finlay. Habana, 1881.

Annual Report of the Chief Sanitary Officer, Havana, 1901-1902: Yellow Fever.

"Diplomatic and Consular Reports : Cuba." Report for year 1907, Anuual Series, No. 4180, p. 12.

"Eradication of Yellow Fever in Havana." Edmond Gouchon. Reprinted from the Medical Record, 25th October 1902.

Etudes pour servir à l'histoire de la Fièvre Jaune ou vomito dans l'âle de Cuba. Pierre Selsis, 1880.

La Fièvre Jaune à la Havane. Charles Belot, 1865.

Sanidad y Beneficiencia. Tomo ii., No. 2 ; Tomo i., No. 1. Habana.

Réfutation des recherches sur la Fièure Jaune faites par iI. P. Gibier à la Havane. Par le Dr Domingos Fri rre, 1888.

"The Etiology of Yellow Fever." Reed, Carroll, Agramonte, and Lazear. T'rans. of the Third Pan-American Med. Congress, Havana, 1901.

\section{AFRICA}

De la cachexie paludéenne en Algérie. M. Catteloup, 1852.

Campagne antipaludique de 1908. Alger, 1909. 
De la Fiève Bilieuse mélanurique des pays chauds comparée avec la Fièvre Jaune: Étude clinique faite au Sénégal. L. J. B. Bérenger-Féraud. Paris, 1874.

De la Fièvre Jaune au Sénégal : Étudefaite dans les hôpitaux de Saint Louis et de Gornée. L. J. B. Bérenger-Féraud. Paris, 1874.

La Fièvre Jaune, épidemie de l'année 1900, à Saint Louis du Sénégal. Charles Carpot. Bordeaux, 1901.

\section{EUROPE}

Relatorio da epidemia de febre amarella em Lisboa no anno de 1857 feito pelo conselho extraordinario de saude publica do reino creado por decreto de 29 de Setembro de 1857.

breve descripcion de la fiebre amarilla padecida en Cadiz y pueblos comarcanos en 1800, en Medinasidonia en 1801, en Malaga en 1803, y en esta misma plaza y varias otras del reyno en 1804 . Don J. Manuel de Arejula, 1806.

Relation historique et médicale de la Fièvre Jaune qui a regné à Burcelone en 1821. M. F. M. Audouard, 1822.

\section{ERUPTIVE FEVERS-LEPROSY}

On an Epidemic of Smallpox of an Irregular Type in Trinidad during 1902-4. R. Seheult. London, 1908.

"Mild and Irregular Forms of Smallpox." Herman Spalding. Journ. Amer. Med. Ass., August 1901.

"Notes on a Mild Type of Smallpox." F. Montizambert. Brit. Med. Journ., 1901, vol. i., p. 1134.

"Varioloid Varicella in Jamaica." Izett Anderson. Pro. Epid. Soc., London, 1867.

Papers relating to Leprosy in certain British Colonies. Colonial Office, 1909.

Studies upon Leprosy: Nature Treatment. W. R. Brinckerhoff. 8vo. Washington, 1909.

\section{YELLOW FEVER IN UNITED STATES}

"The Cost of Yellow Fever Epidemics, and the Epidemic at Decatur, Ala, 1888." W. R. Forest. Medical Record, New York, 1889, vol. xxxv.

"An Account of the Destruction of Mosquitos in the 'Original 'Infected

District in the New Orleans Epidemic of 1905, together with the Yellow Fever Statistics of that District." T. D. Berry. Med. Record, 1907, vol. lxxii., pp. 421-27. 


\section{N D E X}

Agramonte, Dr, 26

Ague, fever and, 50

Amazon, 115, 118

and health progress, 306

and yellow fever, 119, 309

America, Central and Southern, 309 health progress, 306

Antilarval bye-laws, 54 measures, 49-75, 296, 306

Anæmia, tropical, see Ankylostomiasis

Ankylostomiasis, 50

and Bahamas, 260

and Bermuda, 260

and British Guiana, 260, 243, 244, 245

circulars relating to, 224, 253-263

and emigrants, 257

and Jamaica, 261

and labour, 223

and Leeward Islands, 261

and Porto Pico, 301

and St Lucia, 185, 266

and St Vincent, 172

and sugar estates, 219, 220, 221, 223, $224,246,256$

and Trinidad, 219, 220, 224, 249

and West Indies, 260

and Windward Islands, 262

A nopheline mosquitos, 50

Antigua, 10, 37

BaHAMAS, 15

antilarval laws, 73

health progress in, 302
Barbados, 12, 13, 14, 15, 16, 92, 146

antilarval laws, 55

cessation of epidemic, 90

cleaning up, 122

climate of, 143

commissioners, 127

and dengue fever, 97

diagnosis of early cases, 92

difficulties of diagnosis, 94, 141

diseases in, 143

division into parishes, 127

early epidemics, 85

and early notification, 97

entomologist, 147

epidemic jaundice, 96

filariasis, 146

fumigation of houses, 138

gastric influenza, 95

health progress, 122

health reports, 133

intimidation in, 101, 102, 103

isolation hospital, 137

leg, 146

and malaria, $82,97,144,145$

medical administration, 127

mild cases, 93

mortality returns, 136

mosquito destruction, circulars relating to, 268

mosquito survey, 122, 124

need of a medical officer, 135

notification fear, 99

origin of epidemic, 85

prosecutions, 57, 126

press of, 98 
Barbados, quarantine administration, 141, 142 quarantine laxity, 113 quarantine precautions, 112 sanitary administration, 127 sanitary system, 129, 131 sickness returns, 136 size of epidemic, 91 source of infection, 112 spread of epidemic, 89 tardy notification, 105 water-supply, 125 Weil's disease, 96 1909 yellow fever epidemic, 84

Beauperthuy, Dr, 22, 25, 26

Blackwater fever and Trinidad, 207

Blair, Dr, 11, 16

Branch, Dr (the late), 166

Bridgetown, 87, 89, 123

British Guiana, 2, 16 Ankylostomiasis, 243 and Anophelines, 236 antilarval laws, 69 antimosquito measures, 237, 239 Colonial Hospital, 245 complaints against Barbados, 249 and disease returns, 243 drainage, 70 early history, yellow fever, 230 and education, 241 and entomology, 234 health progress, 228 and leprosy, 245 and malaria, 239, 241 medical administration, 247 mortality returns, 242 mosquito prevention, 69 and mosquitos, 235 quarantine administration, 247 sanitary administration, 245 and screening measures, 241 on tardy notification of Barbados, 247 vat-screening, 70 British Hondurasdrainage, 306 and dengne fever, 306
British Honduras, health progress, 304 mosquito destruction ordinance, 306, 307, 308, 309

quarantine ordinance, 309

yellow fever, 305

Brown, Dr, 8

Bulam fever, 3

Bulama, 152

Carroll, Dr, 26

Carter, Dr, 26

Carthagena, 6

Chamberlain, The Rt. Hon. Joseph, 38

Chisholm, Dr, 151

Clare, Surgeon-General, 201, 206, 211

Coup de barre, 3

Cuba, 49

National Board of Health and Charities, 300

and Porto Rico, health progress of, 299

sanitary reforin, 299

and yellow fever, 299,300

Culicidæ, 52

Dandy fever, 50

Dengue fever and Barbados, 97

Dengue fever, 53, 306

Dickson, Dr J. R., 206, 207

Dominica, 10, 11

Duque, Dr Mattias, 301

Durrant, Dr C. H., 165

Du Tertre, Père, 3

Dutrotlau, Dr, 11

Education as a prophylactic factor, 41

Fever and ague, 50

dandy, 50

dengue, 53,306

eruptive, 290

Filariasis, 50, 53

and Barbados, 146

St Vincent, 173 
Finlay, Dr, 26

Fleas, 53

Fly, the house, 53

GASTRIC Influenza, 95

Georgetown, Demerara, 11, 16, 239

removal of bush, 233

Stegomyia survey, 232

yellow fever, 11

Godfrey, Surgeon-General, 232

Grand Turk, s.s., 77

Grenada, 12, 149

antilarval bye-laws, 57

antilarval measures, 154, 158, 159

antimalarial measures, 158,159

antimosquito measures, 158, 159

board of health, 155

division of island, 154

early epidemics in, 151

early history of yellow fever, 151

and eruptive fevers, 160

health administration, 154

health progress, 149

and malaria, 156, 157

mosquito survey, 153

principal towns, 155

public health ordinance, 59,156

rat ordinance, 286

recent cases of yellow fever, 153

and tuberculosis, 161

and yaws, 160

Guadeloupe, 2, 11

Guiteras, Dr, 45

Hankey, ship, 3, 77, 151

Harrison, Prof., 26

Dr, 309

Havana, 6, 49

Hill, Luke M., 232

Hodrler, Major, 185

Hook-worm, 53 (see also Ankylostomiasis)

Hunter, Dr, 9

Hutson, Dr, 89, 95, 108, 109, 123

Hutson's report on yellow fever in

St Lucia, Barbaclos, 270
Indefatigable, H.M.S., 87, 88

India, 47, 81

Inflammatory fever, 293

Insect pests, 49

Isthmian Canal, 49

$J_{\text {AMAICA, }} 8,16$ antiplague measures, 285

health progress in, 302

and malaria, 302

and yellow fever, 302

Jaundice, epidemic. 96

Kean, Colonel, 300

Kendall's disease, 3

King, Dr A., 180, 181, 183, 184

Kingsley, Charles, 18

Kingstown, mosquito survey, 169

divisions of, 163

St Vincent, 162

Labat, Père, 3

Larval, anti-, measures, 49-75, 296, 306

Lassalle, Dr C. M., 206

Law, Dr, 234, 244

Lazear, Dr, 26

Leeward Islands, 9

Leprosy, Barbados, 146

British Guiana, 245

Trinidad, 225

Mal de Siam, 3

Malaria, 37

and Barbados, 82, 97, 143, 144, 145

and British Guiana, 239, 240, 241, 242, 243

and British Honduras, 306

and Grenada, 156, 157, 158

and Jamaica, 302

and millions, 145, 159

and slaves, 82

and St Lucia, 184, 185, 186

and St Vincent, 171, 172

and Suez Canal, 81

and sugar estates, 219, 220

and Tobago, 220

and Trinidad. 207. 208, 209 
Malaria and water-supplies, 37

Manson, Sir Patrick, 26

Martinique, 10, 11, 115, 295

antimosquito laws, 296

and health progress, 292

history of recent outbreak, 293, 294

history of yellow fever in the past, 292 prophylaxis, 295

Maranhense, s.s.. 120

Maunsell, Dr, 9

Wontserrat, 10

Mosquito-carried diseases in St Lucia, reports on, 264, 265

Mosquitos, 52

Moxley, Rev. Sutton, 26

Musgrave, Dr, 10

NASSAU, 15 antilarval laws, 73

Health Act, 1907, 74

Nevis, 10

New Orleans, 49

Northern Islands, health progress in, 304

Notification, tardy circular on, 276

Nott, Dr, 26

\section{Oriflamme, s.s., 3,77}

Parasites, intestinal, 53

Paterson, Dr G. W., 153

Pavy, Dr, 107

Pellagra, 143

Plague, 53, 81, 87

British Guiana, 288

Grenada, 160

Grenada Rat Ordinance, 286, 287

Jamaica, anti-, 285

San Francisco, 44

Trinidad, 225, 288, 289

Plague measures, British Guiana and

Trinidad, 288

Port of Spain, 215

Porto Rico, 2

and tropical anæmia, 301

Psilosis pigmentosa, 143

P./ramus, H.M.S., 107
ReID, Dr, 26

Rose, 50

Ross, Major, 26

St Domingo, 2, 11, 16, 116

St George, town of, 150

St Kitts, 10, 14

St Lucia, 13, 141, 142

and ankylostomiasis, 185

antilarval bye-laws, 63

antimosquito measures, 179

early epidemics, yellow fever, 174,175

health progress, 174

history of yellow fever, 181

and malaria, 184

mosquito destruction, 65,177

mosquito survey, 180

Public Health Acts, 176

quarantine administration, 183 and yaws, 185

St Vincent, 13, 115

ankylostomiasis, 172

antilarval bye-laws, 60

filariasis, 173

fumigation, 167

health administration, 165

health progress, 162

and malaria, 171

medical organisation, 164

mosquito survey, 169

parishes of, 162

Public Health Acts, 165

recent cases, yellow fever, 116,166 , 167

tuberculosis, 173

San Fernando Hospital, 226

Screening, isolation, fumigation, circular on Barbados, 274

Ships and yellow fever, $3,77,79,80$

Slaves and disease, 82 and malaria, 82

Smallpox, atypical, 290

Stegomyia calopus, names of, 29

calopus, 27,52

in Europe, 78

larvæ of, 31

in ships, 79,80 
Suez Canal and malaria, 81

Surinam, 115

Tagus, R.M.S.P., 149

Tortola, 10

Tobago, 10, 14, 207

Trade routes and yellow fever, 76

Treves, Sir Frederick, 18, 149

Trinidad, 10, 11, 12, 13, 47, 116, 117 Anophelines of, 209 and ankylostomiasis, 219, 220, 240 antilarval bye-laws, 66

and blackwater, 207

difficulties of diagnosis, 201

early history of yellow fever, 10, 11, $12,13,187,188$

entomologist, 208

General Board of Health, 214

health on estates, 219

health progress, 187

and leprosy, 225

and malaria, 207, 219

mortality, 191

mosquito survey, 208

number of cases of yellow fever, 190

origin of outbreak, yellow fever, 191 and plague, 225

prosecutions, 67,68

recent epidemic yellow fever, 116, 117,189

sanitary administration, 214,215 , 216,217

sanitary science training, 211, 212, 213

sanitary staff of Port of Spain, 216218

and smallpox, 225

Stegomyia survey, 205

teaching of hygiene, 213

Town Board, 215

and tuberculosis, 225

and Venezuela, 192, 201

water-supply, 188

and yaws, 226

yellow fever prophylaxis, 202

Tuberculosis, Grenada, 161

British Guiana, 245
Tuberculosis, St Vincent, 173

Trinidad, 225

URICH, Mr F. W., 208

Uncinariasis (see Ankylostomiasis)

VARICELLA, 290

Venezuela, 115

and fevers, 197

and health administration, 194

health of, 199

and Trinidad, 192, 201

and yellow fever, 194, 196-201

WAKES, prevention of, 269

Water-supply and yellow fever, 34-36

Weil's disease, 96

Windward Islands, 9

YARWOoD, Mr Graham, 123

Yaws and Grenada, 160

and St Lucia, 185

and Trinidad, 226, 227

Yellow fever and Beauperthuy, 22

and Africa, 3

and Arnazon, 115, 118, 119, 310

and Barbados, $3,12,13,14,84-121$, 268, 283

and British Guiana, 16, 228, 231

and British Honduras, 305

and Carthagena, 6

causes of, 20, 25, 26-28, 29, 30

and Central America, 193, 194, 195

and clerical co-operation, 43,44

and climate, 21

and Cuba, 299, 300

difficulties of diagnosis, $92,93,94$, 95

and Dominique, 101

Dr Hutson's Report on St Lucia and Barbados, 270

early diagnosis, 130,141

early history of, 1, 2, 3

education, 41, 45, 46

and Europe, 5

fumigation, 138

and Georgetown, 11, 16, 17, 18 
Yellow fever and Grenada, 3, 12, 150, 152,153

and Guadeloupe, 2, 11

and Gulf Stream, 20

and Havana, 6

and hospitals isolation, 137

incubation period, extrinsic, 28

in $\operatorname{man}, 27$

in mosquito, 28

intimidation, 101, 102, 103, 104

and Jamaica, 8, 9, 16, 302

larval, anti-, laws, 54-75

and Latin Republics, 309

and Leeward Islands, 9

and Martinique, 115, 292, 293, 294

mild cases, 93

and Montserrat, 10

and Nassau, 15

and Nevis, 10

notification, tardy, 284

early, 97, 98, 99, 100, 105

periodicity, 107

and Porto Rico, 299, 300

prophylaxis, 32, 108, 154, 202, 237, 295

quarantine precautions, 112, 114, $139,140,183$
Yellow fever, race incidence, 106 recent outbreaks, 189, 190, 191

rules for dealing with, 278,279 , 280 .

and St Domingo, 2

and St Lucia, 13, 174, 175, 181, 182, 140,142

and St Vincent (1909 cases), 166

and St Vincent, 13, 15, 116

and sea mosquitos, 23

season of outbreak, 108

and ships, $77,78,79$

source of outbreak, 112

and stagnant water, 34-36

and Surinam, 115

and trade routes, $76-83$

treatment of, 281,283

and Trinidad, 10, 11, 12, 13, 187, $188,116,117$

and Tobago, 10

and Tortola, 10

and United States, 5

and Venezuela, 115, 194, 196-201

and water-supply, 188

West Indies, 3

Windward Islands, 9

"Yellow jack," 78 


UC SOUTHERN REGIONAL. LIBRARY FACILITY 
